Reconnaissance Investigation of Water Quallity, Bottom Sediment, and Blota Associated with

Irrigation Drainage in the Dolores Project

Area, Southwestern Colorado and

Southeastern Utah, 1990-91

by David L. Butler, U.S. Geological Survey;

Richard P. Krueger and Barbara Campbell Osmundson,

U.S. Fish and Wildlife Service; and

Errol G. Jensen, Bureau of Reciamation

U.S. GEOLOGICAL SURVEY

Water-Resources Investigations Report 94-4041

U.S. GEOLOGICAL SURVEY

U.S. FISH AND WILDLIFE SERVICE

BUREAU OF RECLAMATION

BUREAU OF INDIAN AFFAIRS

Denver, Colorado

1995

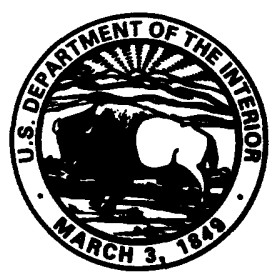




\section{U.S. DEPARTMENT OF THE INTERIOR \\ BRUCE BABBITT, Secretary}

U.S. GEOLOGICAL SURVEY

Gordon P. Eaton, Director

The use of trade, product, industry, or firm names is for descriptive purposes only and does not imply endorsement by the U.S. Government.

For additional information write to:

Copies of this report can be purchased from:

District Chief

U.S. Geological Survey

Box 25046, MS 415

Denver Federal Center

Denver, CO 80225
U.S. Geological Survey

Earth Science Information Center

Open-File Reports Section

Box 25286, MS 517

Denver Federal Center

Denver, CO 80225 


\section{CONTENTS}

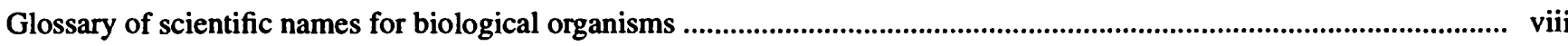

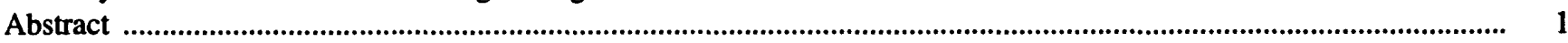

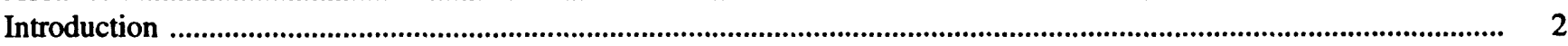

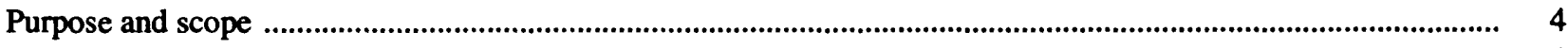

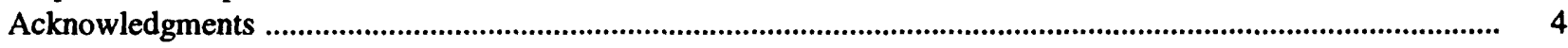

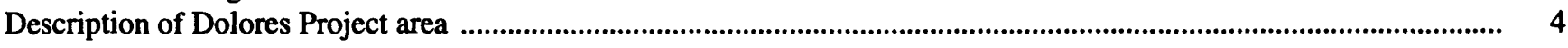

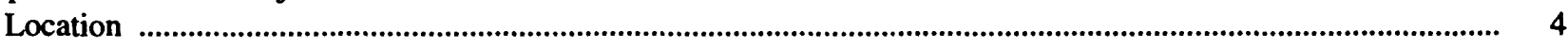

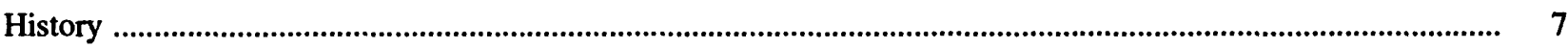

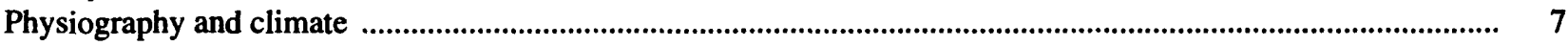

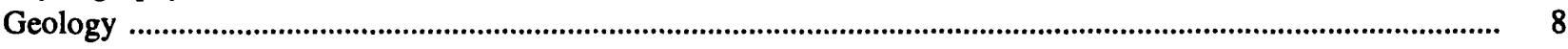

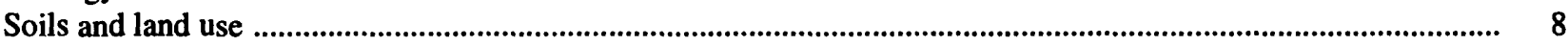

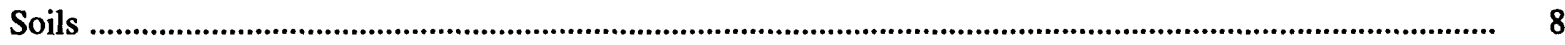

Land use ................................................................................................................................................. 9

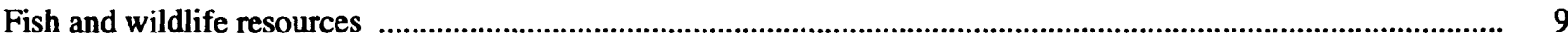

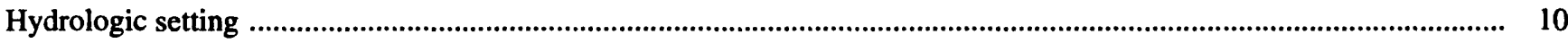

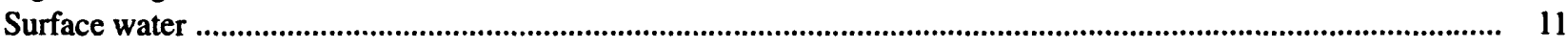

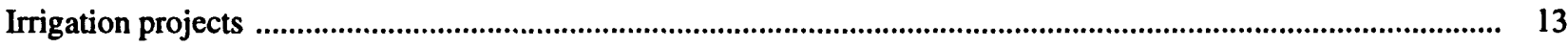

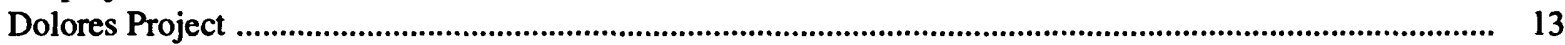

Ute Mountain Ute Irrigation Project ....................................................................................................... 15

Mancos Project ............................................................................................................................................... 15

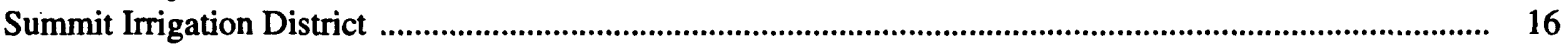

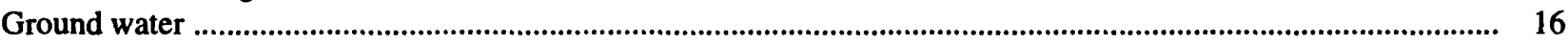

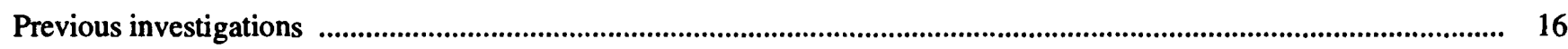

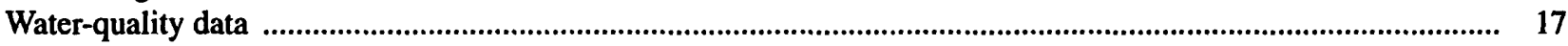

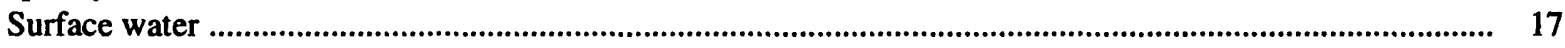

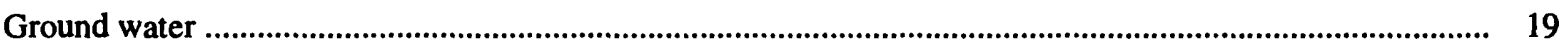

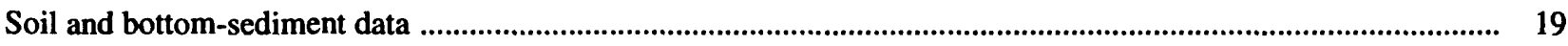

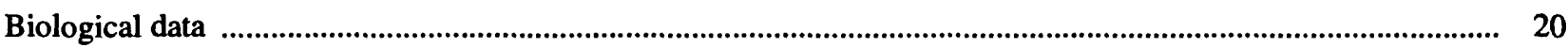

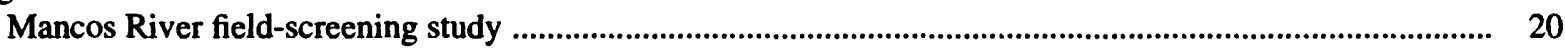

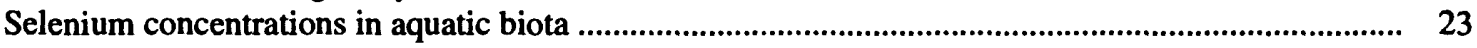

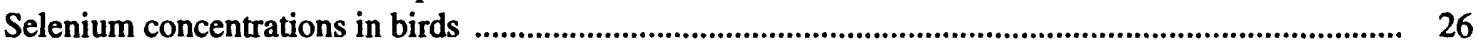

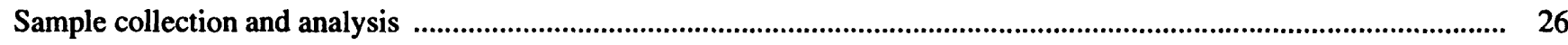

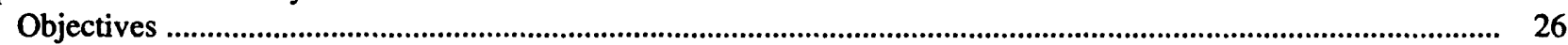

Sampling sites and schedule of sample collection ...................................................................................

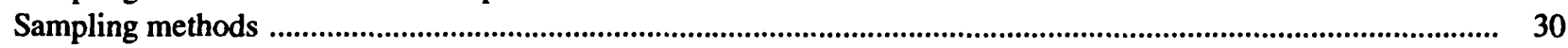

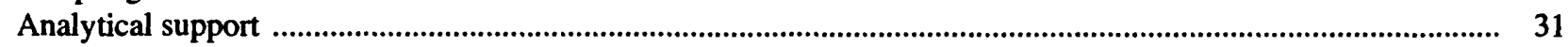

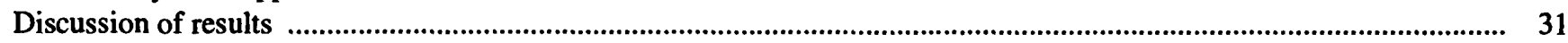

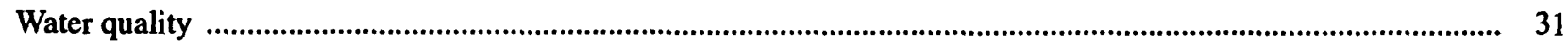

Guidelines for interpretation of water-quality data ............................................................................................ 32

Dissolved solids and major constituents ............................................................................................ 34

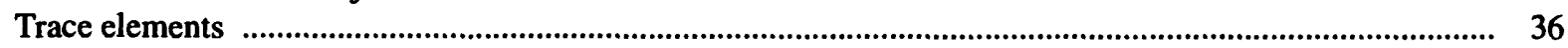

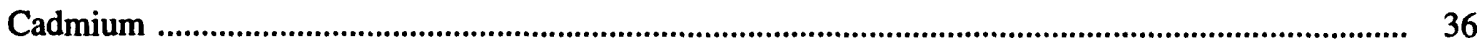

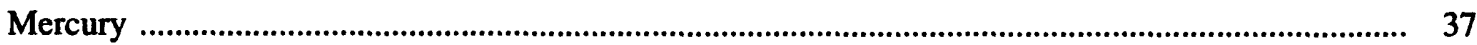

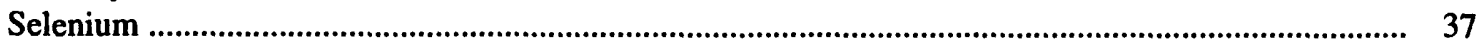

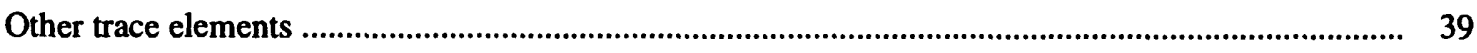

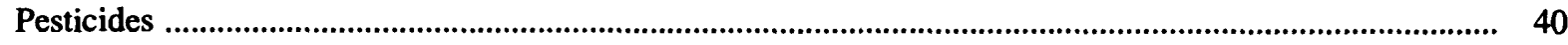

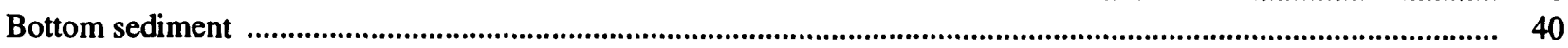

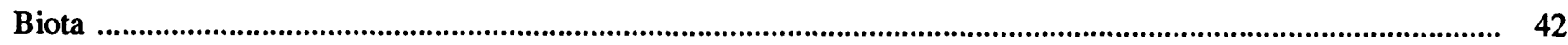

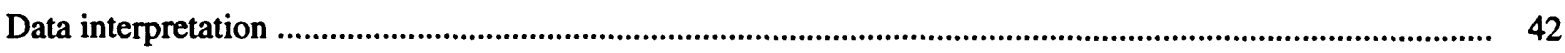

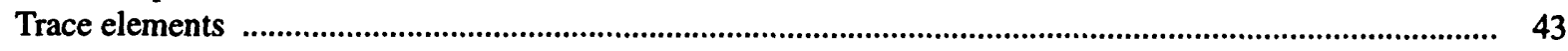

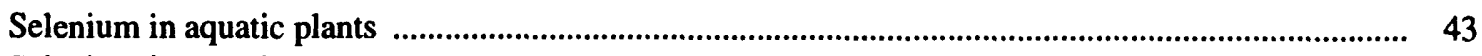

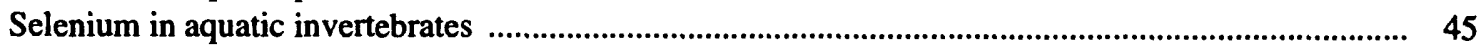


Selenium in fish

Selenium in birds

Mercury

Aluminum

Arsenic

Boron

Cadmium

Chromium

Copper

Lead

Zinc

Organochlorine pesticides

Summary

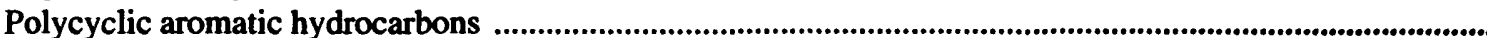

References cited

Supplemental data

\section{FIGURES}

1. Map showing location of data-collection sites and extent of irrigated areas in the Dolores Project area

2. Map showing general location of the Dolores Project area and location of data-collection sites in Utah

3. Schematic diagram showing major streams, tributaries, reservoirs, canals, and movement of water in the Dolores Project area

4-13. Graphs showing:

4. Daily mean stream discharge for October 1989 through November 1990 , average daily mean stream discharge for water years 1962-89, and dates when water-quality samples were collected at streamflow-gaging station 09379500, San Juan River at Mexican Hat, Utah (site SJ3).

5. Annual mean stream discharge at streamflow-gaging station 09379500, San Juan River at Mexican Hat, Utah (site SJ3), water years 1962-90

6. Daily mean stream discharge for October 1989 through November 1990 , average daily mean stream discharge for water years 1952-89, and dates when water-quality samples were collected at streamflow-gaging station 09372000, Mc Elmo Creek near the Colorado-Utah State line (site ME3)

7. Water-level measurements for wells OW1, OW2, and OW3, January 1990-October 1991

8. Concentrations of selenium in surface-water samples from Mc Elmo Creek, Simon Draw, Hartman Draw, Alkali Canyon, Dawson Draw, and Navajo Wash in 1990

9. Concentrations of selenium in surface-water samples from Yellow Jacket Canyon, Woods Canyon, Cahone Canyon, Cross Canyon, the Mancos River, and the San Juan River in 1990

10. Geometric mean selenium concentrations in dietary items of fish and wildlife

11. Geometric mean selenium concentrations in whole-body sucker samples collected from streams................

12. Geometric mean selenium concentrations in whole-body sucker samples collected from streams draining the MVIC (Montezuma Valley Irrigation Company) area

13. Geometric mean mercury concentrations in fillet and whole-body fish samples

\section{TABLES}

1. Water delivery and irrigated acreage in the Dove Creek area of the Dolores Project, 1987-90

2. Median and maximum concentrations of trace elements in water samples collected at streamflow-gaging station 09372000, Mc Elmo Creek near the Colorado-Utah State line (site ME3)

3. Median and maximum concentrations of trace elements in water samples collected at streamflow-gaging stations 09371010, San Juan River at Four Corners (site SJ1), and 09379500, San Juan River at Mexican Hat, Utah (site SJ3) 


\section{TABLES (Continued)}

4. Maximum and minimum concentrations of selected trace elements in four soil samples from Dawson Draw (near site DD)

5. Range of trace-element concentrations in bottom-sediment samples collected at Mc Elmo Creek near the Colorado-Utah State line (site ME3) and at San Juan River at Four Corners (site SJ1)

6. Concentrations of trace elements in seven sections of a core sample of bottom sediment collected from Narraguinnep Reservoir, July 1990

7. Trace-element data for biota samples collected in the Dolores Project area in May and June $1988 \ldots \ldots . . . . . . . . . . . . . . . . .221$

8. Selected trace-element data for fish samples collected in the Dolores Project area in December 1988 .................. 22

9. Trace-element concentrations in water, bottom-sediment, and biota samples collected in the Mancos River basin, July 1, 1989

10. Constituents analyzed in water, bottom-sediment, and biota samples

11. Sampling sites and type of samples collected for the reconnaissance investigation during $\mathbf{1 9 9 0}$

12. Collection schedule of water, bottom-sediment, and biota samples for the reconnaissance investigation during 1990

13. Drinking-water regulations and aquatic-life criteria of the U.S. Environmental Protection Agency and agricultural-use criteria of the State of Colorado

4. Number of water samples collected in the Dolores Project area that had constituent concentrations exceeding drinking-water regulations and aquatic-life criteria of the U.S. Environmental Protection Agency and exceeded agricultural-use criteria of the State of Colorado

15. Statistical summary of trace-element concentrations in water samples collected in the Dolores Project area in 1990

16. Statistical summary of selected trace-element concentrations in bottom-sediment samples collected in the Dolores Project area in November 1990

17. Background geochemical data for soils in the Western United States and the observed range of traceelement concentrations in bottom-sediment samples collected for the U.S. Department of the Interior's Irrigation Drainage Program from 1986-88

18. National Contaminant Biomonitoring Program (NCBP) 85th-percentile concentrations for 1984 and the number of whole-body fish samples collected in the Dolores Project area that exceeded the 85th percentile for 1984

19. Statistical summary of selenium concentrations in selected biota samples collected in the Dolores Project area in 1990

20. Mean mercury concentrations in fillets of game fish collected in the Dolores Project area, 1988-91, and recommended human consumption limits

21. National Contaminant Biomonitoring Program (NCBP) geometric mean concentrations of selected organochlorine pesticides and PCB's for 1984

22. Physical properties and inorganic constituent concentrations in water samples collected in the

Dolores Project area from March through November, 1990.

23. Pesticide concentrations in water samples collected in the Dolores Project area in July 1990.

24. Trace-element concentrations in the less than 0.0625 -millimeter size fraction in bottom-sediment samples collected in the Dolores Project area in 1990.

25. Trace-element concentrations in the less than 2-millimeter size fraction in bottom-sediment samples collected in the Dolores Project area in 1990

26. Concentrations of organic compounds in bottom-sediment samples collected in the Dolores Project area in 1990 .

Trace-element concentrations in aquatic-plant, aquatic-invertebrate, fish, and bird samples collected in the Dolores Project area, April through November, 1990.

Concentrations of selected pesticides and polychlorinated biphenyls (PCB's) in fish and bird samples

29. Polycyclic-aromatic hydrocarbon (PAH) concentrations in fish bile collected in the Dolores Project area, 1990-91 


\begin{tabular}{rll} 
Multiply & By & To obtain \\
acre & $\cdot$ & \\
acre-foot (acre-ft) & 4,047 & square meter \\
acre-foot per year (acre-ft/yr) & 1,233 & cubic meter \\
centimeter $(\mathrm{cm})$ & 1,233 & cubic meter per year \\
cubic foot per second $\left(\mathrm{ft}^{3} / \mathrm{s}\right)$ & 0.3937 & inch \\
foot $(\mathrm{ft})$ & 0.028317 & cubic meter per second \\
gallon per minute $(\mathrm{gal} / \mathrm{min})$ & 0.3048 & meter \\
gram $(\mathrm{g})$ & 0.06309 & liter per second \\
inch $(\mathrm{in})$. & 0.03527 & ounce \\
kilogram $(\mathrm{kg})$ & 25.40 & millimeter $(\mathrm{mm})$ \\
liter $(\mathrm{l})$ & 2.205 & pound \\
micrometer $(\mu \mathrm{m})$ & 0.26427 & gallon \\
mile $(\mathrm{mi})$ & 0.00003937 & inch \\
millimeter $(\mathrm{mm})$ & 1.609 & kilometer \\
ounce $(\mathrm{oz})$ & 0.03937 & inch \\
square mile $\left(\mathrm{mi} \mathbf{2}^{2}\right)$ & 28.35 & gram \\
ton per day (ton/d) & 2.589 & square kilometer \\
ton per year (ton/yr) & 0.9072 & metric ton per day \\
& 0.9072 & metric ton per year \\
\hline
\end{tabular}

Degree Celsius $\left({ }^{\circ} \mathrm{C}\right)$ may be converted to degree Fahrenheit $\left({ }^{\circ} \mathrm{F}\right)$ by using the following equation:

$$
{ }^{\circ} \mathrm{F}=9 / 5\left({ }^{\circ} \mathrm{C}\right)+32 \text {. }
$$

Degree Fahrenheit $\left({ }^{\circ} \mathrm{F}\right)$ may be converted to degree Celsius $\left({ }^{\circ} \mathrm{C}\right)$ by using the following equation:

$$
{ }^{\circ} \mathrm{C}=5 / 9\left({ }^{\circ} \mathrm{F}-32\right) \text {. }
$$

The following terms and abbreviations also are used in this report:

microgram per gram $(\mu \mathrm{g} / \mathrm{g})$.

microgram per kilogram $(\mu \mathrm{g} / \mathrm{kg})$.

microgram per kilogram per day $(\mu \mathrm{g} / \mathrm{kg} / \mathrm{d})$.

microgram per liter $(\mu \mathrm{g} / \mathrm{L})$.

milligram per kilogram (mg/kg).

milligram per liter $(\mathrm{mg} / \mathrm{L})$.

microsiemens per centimeter at 25 degrees Celsius ( $\mu \mathrm{S} / \mathrm{cm})$.

2,4-D 2,4-dichlorophenoxy-acetic acid

2,4-DP 2-(2,4-dichlorophenoxy) propionic acid

2,4,5-T 2,4,5-trichlorophenoxy-acetic acid

BHC benzene hexachloride 


$\begin{array}{ll}\text { DDD } & \text { 1,1-dichloro -2,2-bis (p-chlorophenyl) ethane } \\ \text { DDE } & \text { dichloro diphenyl dichloroethylene } \\ \text { DDT } & \text { dichloro diphenyl trichloroethane } \\ \text { HCB } & \text { hexachlorobenzene } \\ \text { PCN } & \text { polychlorinated naphthalenes } \\ \text { PCB } & \text { polychlorinated biphenyls }\end{array}$

For those who wish to convert dry-weight concentrations to wet-weight concentrations for biological samples, the equation is:

wet weight $=$ dry weight $[1-($ percent moisture $) / 100]$. 


\section{GLOSSARY OF SCIENTIFIC NAMES FOR BIOLOGICAL ORGANISMS}

[sp., species; --, too numerous to list]

\begin{tabular}{|c|c|c|}
\hline Common name & Order/family & Genus/species \\
\hline \multicolumn{3}{|c|}{ AQUATIC PLANTS } \\
\hline Coontail & Ceratophyllaceae & Ceratophyllum sp. \\
\hline Sago pondweed & Potamogetonaceae & Potamogeton sp. \\
\hline Horned pondweed & Naidaceae & Zannichellia sp. \\
\hline Watercress & Brassicaceae & Nasturtium sp. \\
\hline \multicolumn{3}{|c|}{ AQUATIC INVERTEBRATES } \\
\hline Crayfish & Decapoda/Astacidae & -- \\
\hline \multirow[t]{8}{*}{ Aquatic insects } & Diptera & -- \\
\hline & Coleoptera & -- \\
\hline & Hemoptera & - \\
\hline & Plecoptera & - \\
\hline & Ephemerotera & - \\
\hline & Odonata & - \\
\hline & Trichoptera & -- \\
\hline & \multicolumn{2}{|l|}{ FISH } \\
\hline Rainbow trout & Salmonidae & Oncorhynchus mykis \\
\hline Kokanee salmon & Salmonidae & Oncorhynchus nerka \\
\hline Northern pike & Esocidae & Esox lucius \\
\hline Walleye & Percidae & Stizostedion vitreum \\
\hline Yellow perch & Percidae & Perca flavescens \\
\hline Largemouth bass & Centrarchidae & Micropterus salmoides \\
\hline Smallmouth bass & Centrarchidae & Micropterus dolomieui \\
\hline Black crappie & Centrarchidae & Pomoxis nigromaculatus \\
\hline Green sunfish & Centrarchidae & Lepomis cyanellus \\
\hline Bluegill & Centrarchidae & Lepomis macrochirus \\
\hline Roundtail chub & Cyprinidae & Gila robusta \\
\hline Common carp & Cyprinidae & Cyprinus carpio \\
\hline Fathead minnow & Cyprinidae & Pimephales promelas \\
\hline Speckled dace & Cyprinidae & Rhinichthys osculus \\
\hline Red shiner & Cyprinidae & Cyprinella lutrensis \\
\hline Flannelmouth sucker & Catostomidae & Catostomus latipinnis \\
\hline White sucker & Catostomidae & Catostomus commersoni \\
\hline Bluehead sucker & Catostomidae & Catostomus discobolus \\
\hline Razorback sucker & Catostomidae & Xyrauchen texanus \\
\hline Colorado squawfish & Cyprinidae & Ptychocheilus lucius \\
\hline
\end{tabular}




\section{GLOSSARY OF SCIENTIFIC NAMES FOR BIOLOGICAL ORGANISMS -Continued}

\begin{tabular}{lll}
\hline \multicolumn{1}{c}{ Common name } & \multicolumn{1}{c}{ Order/family } & \multicolumn{1}{c}{ Genus/species } \\
\hline \multirow{2}{*}{ Mallard } & Bnatidae & Anas platyrhynchas \\
American coot & Rallidae & Fulica americana \\
Pied-billed grebe & Podicipedidae & Aechmophorus occidentalis \\
Sora rail & Rallidae & Porzana carolina \\
Red-winged blackbird & Emberizidae & Agelaius phoenicus \\
Yellow-headed blackbird & Emberizidae & Xanthocephalus xanthocephalus \\
& MAMMALS & \\
Muskrat & & Ondatra zibethicus \\
\hline
\end{tabular}




\title{
Reconnaissance Investigation of Water Quality, Bottom Sediment, and Biota Associated with Irrigation Drainage in the Dolores Project Area, Southwestern Colorado and Southeastern Utah, 1990-91
}

\author{
By David L. Butler, Richard P. Krueger, Barbara Campbell Osmundson, andErrol G. Jensen
}

\section{Abstract}

The Department of the Interior started a program in October 1985 to identify the nature and extent of irrigation-induced water-quality problems that might exist in the Western United States. Water, bottom-sediment, and biota samples were collected and analyzed for a reconnaissance investigation during 1990-91 to identify potential water-quality problems associated with irrigation drainage in the Dolores Project area in southwestern Colorado and southeastern Utah.

Concentrations of dissolved solids and sulfate exceeded secondary maximum contaminant levels for drinking water in many water samples from irrigated and nonirrigated areas. Mc Elmo Creek and the Mancos River contribute substantial dissolved-solids loads to the San Juan River.

Cadmium was detected in 19 water samples from 16 sites. Criterion to protect aquatic life from chronic exposure to cadmium was exceeded in two samples, however, these samples were collected from Summit Reservoir and Puett Reservoir, which are located outside the irrigated area served by the Dolores Project. Mercury was detected in 11 water samples at concentrations ranging from 0.1 to 1.2 micrograms per liter, and 6 of those samples were collected at sites outside of the irrigated area served by the Dolores Project.

Selenium concentrations exceeded the chronic aquatic-life criterion for selenium of 5 micrograms per liter in most water samples from Mc Elmo Creek, Navajo Wash, from newly irrigated areas, and from the Mancos River. Irrigation drainage may be the primary source of selenium to Mc Elmo Creek. The maximum selenium concen- tration in water was 88 micrograms per liter in Navajo Wash, which drains irrigated land on Mancos Shale in the southern end of the Montezuma Valley. Only 1 of 15 water samples collected from streams that drain the Montezuma Valley north of Mc Elmo Creek had a selenium concentration greater than 1 microgram per liter. Samples of irrigation drainwater from newly (since 1987) irrigated land in the Yellow Jacket and Cahone areas had selenium concentrations ranging from 3 to 12 micrograms per liter. Selenium concentrations in the San Juan River were 2 micrograms per liter, and selenium was not detected in water samples collected in nonirrigated areas. Concentrations of pesticides in water were less than levels harmful to aquatic life.

Except for selenium concentrations in bottom-sediment samples from four sites, traceelement concentrations in bottom sediment in the Dolores Project area were not elevated when compared to soils in the western United States. The maximum concentration of an organochlorine pesticide in bottom sediment was 5.5 micrograms per kilogram of DDD in a sample from Summit Reservoir.

Generally, selenium concentrations in biota in the Dolores Project area were greatest in samples collected from Navajo Wash, in newly irrigated areas in the Yellow Jacket and Cahone areas, and from the Mancos River basin. Selenium concentrations in aquatic plants and aquatic invertebrates were larger in samples collected in the newly irrigated areas than in the long-term irrigated areas in the Montezuma Valley. Selenium concentrations in 10 of 11 aquatic-invertebrate samples from the newly irrigated areas exceeded a 
guideline for food items consumed by fish and wildlife. The maximum selenium concentration in an aquatic-invertebrate sample was 19.2 micrograms per gram dry weight in a sample from Woods Canyon, in the newly irrigated area. Selenium concentrations in whole-body suckers (all species) were larger in samples from the Mancos River than in sucker samples from the Montezuma Valley or San Juan River. Selenium concentrations in whole-body suckers were significantly higher in samples collected from the San Juan River downstream from the Dolores Project than in samples collected upstream from the project. An assessment of the effects of irrigation drainage from the Dolores Project on endangered fish, such as the Colorado squawfish (Ptychocheilus lucius) in the San Juan River, could not be made for the reconnaissance investigation.

Whole-body samples of fathead minnows from Woods Canyon, in the newly irrigated area, and from the Mancos River had selenium concentrations associated with adverse effects on fathead minnows. As in water samples and other biota samples, the largest selenium concentrations in speckled-dace samples from the Montezuma Valley were collected from Navajo Wash.

Selenium concentrations in bird eggs were within the range of uncertainty regarding biological significance. The largest selenium concentration in a biota sample collected in 1990 was 37.5 micrograms per gram dry weight in a mallard liver from Woods Canyon, in the newly irrigated area. Selenium concentrations ranged from 10 to 69 micrograms per gram dry weight in six birdtissue samples collected in July 1989 within the irrigated area of the Mancos Project, upstream from the Dolores Project.

Mercury concentrations in warm-water game fish in reservoirs in the Dolores Project area may be of concern for human consumption of fish. Weekly dietary limits are most restrictive for consumption of walleye, northern pike, and bass from McPhee, Narraguinnep, Totten, Summit, and Puett Reservoirs. Chromium concentrations in biota samples were indicative of chromium contamination, although chromium concentrations in water and bottom-sediment samples were not elevated. The maximum chromium concentration in a biota sample was 440 micrograms per gram dry weight in a crayfish from the Mancos River. Some con- centrations of aluminum, boron, cadmium, copper, lead, and zinc in biota exceeded background concentrations reported in the literature, but generally the concentrations were not toxicologically significant or the toxicological significance was not known. Previously mined areas in the upper Dolores River basin could have been a source of trace metals and may have been transported into the Dolores Project in the irrigation water supply.

Concentrations of organochlorine pesticides and PCB's in fish and birds in the Dolores Project area were indicative of background concentrations. Polycyclic aromatic hydrocarbons were analyzed in fish-bile samples from 10 sites, but the biological significance of the data is not known.

\section{iNTRODUCTION}

During the last several years, there has been increasing concern about the quality of irrigation drainage and its potential harmful effects on human health, fish, and wildlife. Concentrations of selenium greater than water-quality criteria for the protection of aquatic life (U.S. Environmental Protection Agency, 1987) have been detected in subsurface drainage from irrigated land in the western part of the San Joaquin Valley in California. In 1983, incidences of mortality, birth defects, and reproductive failures in waterfowl were discovered by the U.S. Fish and Wildlife Service at the Kesterson National Wildlife Refuge in the western San Joaquin Valley where irrigation drainage was impounded. In addition, potentially toxic trace elements and pesticide residues have been detected in other areas in Western States that receive irrigation drainage.

Because of concerns expressed by the U.S. Congress, the U.S. Department of the Interior (DOI) started a program in October 1985 to identify the nature and extent of irrigation-induced water-quality problems that might exist in the Western United States. The DOI developed a management strategy and formed an interbureau group known as the "Task Group on Irrigation Drainage", which prepared a comprehensive plan for reviewing irrigation-drainage concerns for which the DOI may have responsibility.

Initially, the Task Group identified 20 areas in 13 States that warranted reconnaissance-level investigations related to three specific activities: (1) Irrigation or drainage facilities constructed or managed by the DOI, (2) national wildlife refuges managed by the DOI, and (3) other migratory-bird or endangered-species management areas that receive water from DOI-funded projects. 
Nine of the 20 areas were selected for reconnaissance investigations during 1986-87:

$\begin{array}{ll}\text { Arizona-California } & \begin{array}{c}\text { Lower Colorado-Gila River } \\ \text { Valley area }\end{array} \\ \text { California } & \text { Salton Sea area } \\ & \text { Tulare Lake Bed area } \\ \text { Montana } & \begin{array}{l}\text { Sun River Reclamation Project } \\ \text { area } \\ \end{array} \\ & \text { Milk River Reclamation Project } \\ & \text { area } \\ \text { Nevada } & \text { Stillwater Wildlife Management } \\ & \text { area } \\ \text { Texas } & \text { Lower Rio Grande-Laguna } \\ & \text { Atascosa National Wildlife } \\ & \text { Refuge area } \\ \text { Utah } & \text { Middle Green River basin area } \\ \text { Wyoming } & \text { Kendrick Reclamation Project } \\ & \text { area }\end{array}$

On the basis of results from these investigations, four detailed studies were initiated in 1988: Salton Sea area, Stillwater Wildlife Management area, Middle Green River Basin area, and the Kendrick Reclamation Project area. Eleven more reconnaissance investigations were initiated in 1988:

\begin{tabular}{|c|c|}
\hline California & Sacramento Refuge Complex \\
\hline California-Oregon & Klamath Basin Refuge Complex \\
\hline \multirow[t]{2}{*}{ Colorado } & $\begin{array}{l}\text { Gunnison and Uncompahgre } \\
\text { River Basins and Sweitzer } \\
\text { Lake }\end{array}$ \\
\hline & Pine River Project area \\
\hline Colorado- Kansas & Middle Arkansas River basin \\
\hline Idaho & American Falls Reservoir \\
\hline New Mexico & $\begin{array}{l}\text { Middle Rio Grande Project and } \\
\text { Bosque del Apache National } \\
\text { Wildlife Refuge }\end{array}$ \\
\hline Oregon & $\begin{array}{l}\text { Malheur National Wildlife } \\
\text { Refuge }\end{array}$ \\
\hline \multirow[t]{2}{*}{ South Dakota } & Angostura Reclamation Unit \\
\hline & Belle Fourche Reclamation Unit \\
\hline Wyoming & Riverton Reclamation Project \\
\hline
\end{tabular}

Evaluation of results for these investigations, and a continuing evaluation of all data for the Irrigation
Drainage Program, led to initiating three more detailed studies early in 1990:

$\begin{array}{ll}\text { California-Oregon } & \begin{array}{c}\text { Klamath Basin Refuge } \\ \text { Complex }\end{array} \\ \text { Montana } & \text { Sun River area } \\ \text { Colorado } & \begin{array}{l}\text { Gunnison River Basin/Grand } \\ \text { Valley Project }\end{array}\end{array}$

In October 1990, four additional reconnaissance investigations were begun and another was started in October 1991. The study areas are:

$\begin{array}{ll}\begin{array}{l}\text { Oregon- Nevada } \\ \text { Nevada }\end{array} & \begin{array}{l}\text { Owyhee-Vale Projects } \\ \text { Humboldt Wildlife Management } \\ \text { area }\end{array} \\ \text { Colorado } & \begin{array}{l}\text { Dolores Project area } \\ \text { New Mexico }\end{array} \\ \text { San Juan River area } \\ \text { Washington } & \text { Middle Columbia River Basin }\end{array}$

One detailed study was started in October 1993:

New Mexico San Juan River area

In October 1993, another reconnaissance investigation was begun:
New Mexico
Vermejo Project area

All reconnaissance investigations are conducted by interbureau study teams consisting of a scientist from the U.S. Geological Survey as team leader, with additional U.S. Geological Survey, U.S. Fish and Wildlife Service, Bureau of Reclamation, and Bureau of Indian Affairs scientists representing several different disciplines. The investigations are directed toward determining whether irrigation drainage: (1) Has caused or has the potential to cause significant harmful effects on human health, fish, and wildlife, or (2) may adversely affect the suitability of water for other beneficial uses.

The Bureau of Reclamation's Dolores Project and areas downstream from the project were selected for a reconnaissance investigation because of possible effects on the water quality of the San Juan River by Mc Elmo Creek, which drains part of the irrigated area, and because the San Juan River downstream from Mc Elmo Creek provides habitat for threatened and endangered fish. The Bureau of Reclamation has iden- 
tified the Mc Elmo Creek basin as a substantial source of dissolved solids in the Upper Colorado River Basin. Historical trace-element data indicated that there were moderate concentrations of selenium and boron in Mc Elmo Creek. The source of all irrigation water for the project is McPhee Reservoir, located on the Dolores River, and there was potential for transport of heavy metals from the Dolores River into the Dolores Project. Of particular concern was mercury accumulation in reservoirs. Mercury concentrations in some fish samples from McPhee Reservoir and from a reservoir located north of Cortez exceeded guidelines for human consumption. The Dolores Project also was chosen because the project would provide an opportunity to collect data in areas that were being irrigated for the first time.

\section{Purpose and Scope}

This report describes results of the reconnaissance investigation of the Dolores Project area. Specific objectives of the reconnaissance investigation were to:

1. Describe concentrations of selected inorganic and organic constituents in water, bottom sediment, and biota in long-term irrigated areas, in newly (since 1987) irrigated areas, and in the Mancos and San Juan Rivers.

2. Compare constituent concentrations to various guidelines and baseline information from the literature to determine if irrigation drainage from the Dolores Project is causing or has the potential to cause harmful effects to human health, fish, and wildlife.

Water, bottom-sediment, and biota samples were collected in 1990 in the Dolores Project area for the reconnaissance investigation. Samples collected in the Mc Elmo Creek basin and from Navajo Wash were used to assess water quality in the long-term irrigated area in the Montezuma Valley. Samples also were collected in selected areas north of the Montezuma Valley that were recently (since 1987) irrigated, from the Mancos and San Juan Rivers, and at reference sites located upstream from irrigated areas of the Dolores Project.

Additional data are included in the report that were not collected for the reconnaissance investigation in 1990. Results of biota sampling by the U.S. Fish and Wildlife Service in the Mancos River basin in 1989 are described in the report. Mercury data for game fish collected from reservoirs in the Dolores Project area during 1988-91 by State and Federal agencies were used to assess mercury concentrations and human consumption limits in game fish. Five fish samples collected in August 1991 for analysis of polycyclic aromatic hydrocarbons are included in the report. Selected groundwater level data collected by the Bureau of Reclamation in 1990-91 in the newly irrigated areas also are described in the report.

\section{Acknowiedgments}

The authors thank various property owners for allowing collection of samples on their property. The authors also thank Kirk Lashmett of the Bureau of Reclamation for assistance with the collection of water and biota samples from reservoirs and Toby Tobiasson of the Bureau of Indian Affairs for his assistance to the study. The authors also acknowledge David W. Grey, Robert W. Boulger, and Kathleen C. Stewart of the U.S. Geological Survey, who assisted with the field collection of water and bottom-sediment samples.

\section{DESCRIPTION OF DOLORES PROJECT AREA}

\section{Location}

Irrigated areas of the Dolores Project are located in the southwestern corner of Colorado in Montezuma and Dolores Counties (fig. 1). The Dolores Project area includes the Mancos River in Colorado and extends into southeastern Utah along the San Juan River to Lake Powell (fig. 2). The Dolores Project was designated as three specific areas (fig. 1) in Bureau of Reclamation planning reports (Bureau of Reclamation, 1977a, b; 1988, 1989), and those designations will be used in this report. The first area is the Montezuma Valley, which is centered around Cortez and was irrigated by nonproject water supplied by the Montezuma Valley Irrigation Company (MVIC); this area is referred to as the MVIC area (fig. 1). The MVIC area will receive supplemental irrigation water from the Dolores Project. The second area is referred to as the Dove Creek area and consists of the five irrigated areas shown in figure 1 between Yellow Jacket Canyon and Monument Creek. The third area is referred to as the Towaoc area and consists of the irrigated areas shown in figure 1 on the southwestern flanks of Sleeping Ute Mountain on the Ute Mountain Ute Reservation. Part of the Dove Creek area was irrigated during 1990, and none of the Towaoc area was irrigated in 1990. 
EXPLANATION

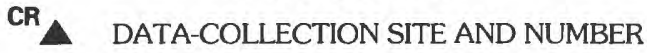
APPROXIMATE EXTENT OF IRRIGATED AREAS OF THE DOLORES PROJECT:

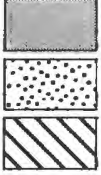

DOVE CREEK AREA

MONTEZUMA VALLEY IRRIGATION

COMPANY (MVIC) AREA

TOWAOC AREA (NOT IRRIGATED DURING STUDY)
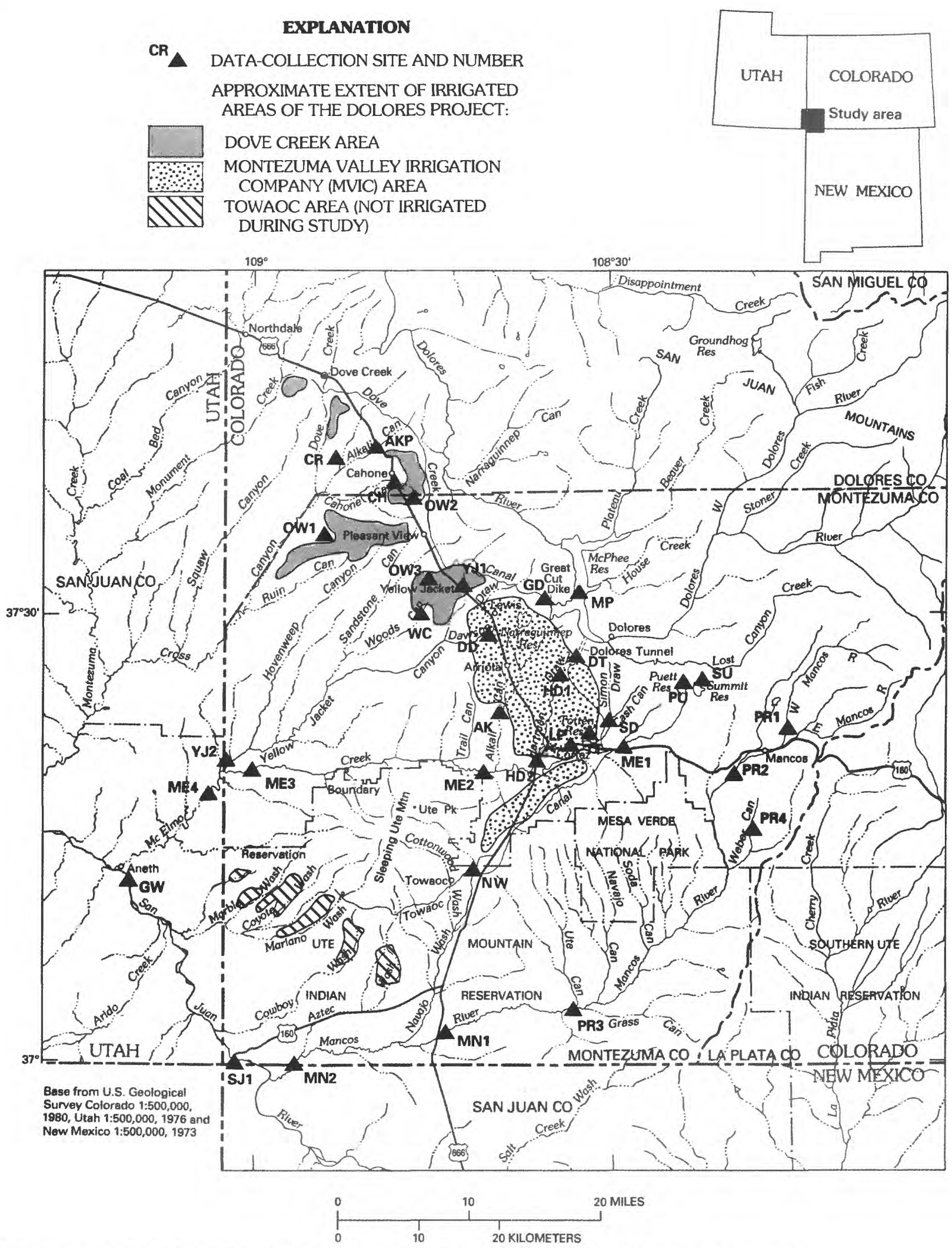

Figure 1. Location of data-collection sites and extent of irrigated areas in the Dolores Project area. 


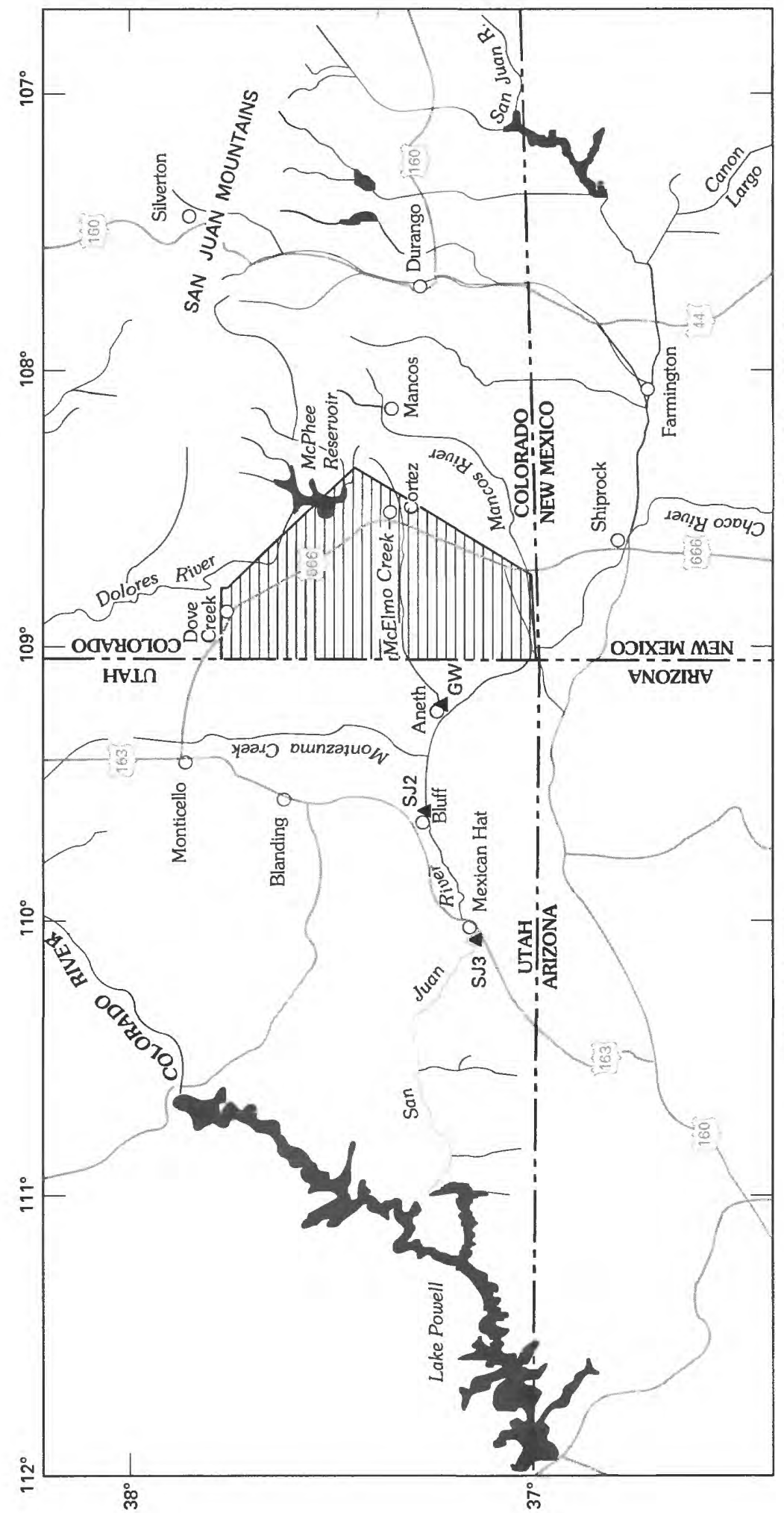

出

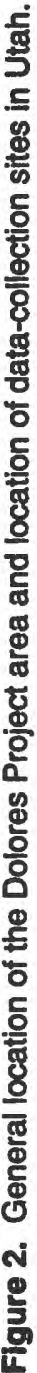




\section{History}

The presence of many Indian ruins in southwestern Colorado (such as in Mesa Verde National Park) indicates that the Dolores Project area was inhabited for many years prior to the arrival of miners and settlers in the 1870's and 1880's. The Ute Indian Reservation was first formally defined by a treaty in 1868 . Between 1870 and 1895 , the reservation size was decreased by several enactments. In 1895, the Ute Indian Reservation was divided into the Ute Mountain Ute Reservation and Southern Ute Indian Reservation. Irrigation began in the 1880's in the Montezuma Valley. A tunnel and canal system was built by private concerns to transport water from the Dolores River into the area for irrigation; the tunnel was completed in 1889. There were several owners of the irrigation company during the next 30 years prior to the Montezuma Valley Irrigation Company. There was adequate precipitation for dryland farming in nonirrigated areas of northern Montezuma Valley and in the Dove Creek area. Stockmen were using the Dove Creek area as early as 1878 . Much of the sagebrush cover was burned, and the Dove Creek area was used exclusively for cattle until 1915, when farming began in the area under the Homestead Act. Dryland farming developed slowly in the area until roads and transportation improved, and then developed rapidly after 1938. Almost all tillable land that was productive by dryland farming was utilized. Agricultural development on the Ute Mountain Ute Reservation has been limited to one small farm and to cattle and sheep grazing.

\section{Physiography and Climate}

The Dolores Project area is located in the Colorado Plateau physiographic province. The area is in a transition zone between the foothills on the southwest flank of the San Juan Mountains (fig. 2) and the mesa and canyon country to the south and west. The Montezuma Valley centered around Cortez is a broad, relatively flat valley. Irrigated areas in the Montezuma Valley are on gently rolling terrain dissected by numerous, shallow streams and swales. South of Mc Elmo Creek, the irrigated lands are on fan and flood-plain deposits of ephemeral streams flowing off the Mesa Verde escarpment. The upland areas consist of foothills and low mountains. The drainage divide that separates the Dolores River basin from the Mc Elmo Creek basin is quite low, and elevations range from about 7,200 to 7,800 ft. Much of the area to the west is desert land featuring high mesas incised by deep canyons. The Dove Creek area of the Dolores Project is on a broad plateau that slopes gently south and is incised by numerous deep canyons. The Towaoc area of the Dolores Project is on the southern and southwestern side of Sleeping Ute Mountain on gently sloping terrain intersected by numerous gullies and deep arroyos. Land to be irrigated in the Towaoc area northwestern of Mariano Wash (fig. 1) is on long fans extending southwest from Sleeping Ute Mountain; project lands southeast of Mariano Wash are in alluvial valleys eroded into shale. The Mancos River flows through a deep canyon on the eastern and southern side of Mesa Verde National Park, and then flows into a broad, open valley. There are numerous small washes and gullies in this area.

A major feature in the Dolores Project area is Sleeping Ute Mountain located southwest of Cortez. Elevation in the project area ranges from about $4,400 \mathrm{ft}$ at the San Juan River in Utah to almost $10,000 \mathrm{ft}$ on Sleeping Ute Mountain. The elevation of Cortez is about $6,200 \mathrm{ft}$. Elevation of the Mc Elmo Creek basin ranges from about 4,600 to $8,500 \mathrm{ft}$. Elevation of the area south of Sleeping Ute Mountain in the Mancos River Valley ranges from about 5,000 to $5,500 \mathrm{ft}$. To the north of Cortez, elevation gradually increases to almost 7,000 ft at Dove Creek.

The Dolores Project area has a continental, semiarid climate. Annual precipitation (1951-80) in the Montezuma Valley area is about 11 to $14 \mathrm{in}$;; in the area to the north toward Dove Creek about 12 to 16 in.; and at lower elevations of western Mc Elmo Creek drainage about 8 to 12 in. Annual precipitation at lower elevations of the Ute Mountain Ute Reservation is 8 to $10 \mathrm{in}$. The mean annual precipitation was $12.72 \mathrm{in}$. at Cortez and 18.07 in. at Dolores for 1951-80 (National Oceanic and Atmospheric Administration, 1990). The wettest months are August and October, the driest month is June. Summer precipitation is characterized by thunderstorms that may have brief, heavy rains. The annual precipitation for calendar year 1990 was slightly above normal (compared to 1951-80) in the Dolores Project area based on precipitation data for Cortez, Mesa Verde National Park, Dolores, and Northdale (fig. 1) (National Oceanic and Atmospheric Administration, 1990). The pan evaporation at the McPhee Reservoir site (elevation $6,900 \mathrm{ft}$ ) was estimated by the Bureau of Reclamation (1977a) to be 42 in. for the growing season (April through October).

The Dolores Project area usually has warm to hot summers and cool winters. Lower elevation areas frequently have daytime summer temperatures exceeding $90^{\circ} \mathrm{F}$. Winters are characterized by mild days and cold nights $\left(12\right.$ to $\left.15^{\circ} \mathrm{F}\right)$. The mean annual temperature for $1951-80$ was $48.8^{\circ} \mathrm{F}$ at Cortez, $50.0^{\circ} \mathrm{F}$ at Mesa Verde National Park, and $45.1^{\circ} \mathrm{F}$ at Northdale. Temperature 
extremes in the Cortez area are $-25^{\circ} \mathrm{F}$ to about $100^{\circ} \mathrm{F}$. The frost free period in the Mc Elmo Creek area ranges from about 133 to 141 days (Bureau of Reclamation, 1981), is slightly longer in the lower Mancos River Valley, and is shorter in the Dove Creek area (about 110 to 120 days). The irrigation season usually begins in late April and ends in October.

\section{Geology}

The geologic map of the Cortez 1:250,000 quadrangle is in Haynes and others (1972). Irwin (1966) described the geology of the Ute Mountain Ute Reservation. Large-scale geologic studies of the San Juan Basin and Paradox Basin include all or parts of the Dolores Project area, and other geologic studies have been done, such as Whitfield and others (1983). Geology of the Mc Elmo Salinity Control Unit is described in reports by Bureau of Reclamation $(1981,1988)$. Geldon (1985) described the geology in the Cottonwood Wash area (fig. 1) near Towaoc on the Ute Mountain Ute Reservation.

The Mc Elmo Creek basin is in the Four Corners structural platform of the Colorado Plateau province. The area has been folded and faulted to some extent. The exposed bedrock primarily is sedimentary rocks of Jurassic through Cretaceous age and some igneous rocks of Tertiary age. Most of the irrigated land in the MVIC area is underlain by the Mancos Shale and Dakota Sandstone of Cretaceous age. There are extensive surficial deposits of eolian material between Cortez and Dove Creek. Much of the irrigated area in the northern Montezuma Valley and Dove Creek area is on soils derived from eolian deposits. The eolian deposits are red-brown loess consisting of unconsolidated silt and sand. In many canyons, the Morrison Formation and other sedimentary formations of Jurassic age crop out. For example, the Morrison Formation crops out in the Mc Elmo Creek Canyon downstream from Cortez, in Yellow Jacket Canyon downstream from Dawson Draw, and along the San Juan River. Sleeping Ute Mountain consists of igneous rocks of Cretaceous and Tertiary age.

The Mancos Shale is a dark gray marine shale that has thin beds of sandstone and limestone. In much of the Dolores Project area, the Mancos Shale is overlain by surficial materials. The formation was named in 1899 for the outcrops along the Mancos River Valley near the town of Mancos (Irwin, 1966). The Bureau of Reclamation has identified the Mancos Shale as a significant contributor of salinity to the Colorado River from other Bureau of Reclamation projects in western Colorado, such as the Uncompahgre Project and the
Grand Valley Project. The Mancos Shale also was identified as a significant source of selenium in irrigated areas in the middle Green River basin in Utah (Stephens and others, 1988; 1992). The Dakota Sandstone is interbedded sandstone, shale, and coal and forms the caprock seen along the top of many of the canyons. The Morrison Formation is variegated shale, sandstone, and mudstone deposits. Some members of the Morrison Formation contain uranium and vanadium, which were mined.

There are other sedimentary rocks exposed along Mesa Verde National Park and Sleeping Ute Mountain. Alluvium of Quaternary age is present in larger stream valleys, including Mc Elmo Creek and the Mancos River. There are various alluvial deposits around Sleeping Ute Mountain, including talus, colluvium, and pediments.

\section{Soils and Land Use}

\section{Soils}

Soils were extensively studied by the Bureau of Reclamation for the Dolores Project (Bureau of Reclamation, 1977b; 1988). Two major soil types are described; the gray soils and the red soils. The gray soils are alluvial in origin, and parent rocks were comprised of shale and sandstone from the Mancos Shale and the Mesaverde Formation. Gray soils often are underlain by shale. The Bureau of Reclamation (1988) described two types of gray soils, flood-plain soils and fan soils. Flood-plain soils were formed by alluvial deposition, primarily along Mc Elmo Creek. Floodplain soils have a sandy loam to silty clay texture, and dissolved-solids concentrations in soil extracts ranged from 550 to $12,000 \mathrm{mg} / \mathrm{L}$ (Bureau of Reclamation, 1988). Fan soils are formed by slope wash and colluvial processes and have a loamy sand to silty clay texture. Dissolved-solids concentrations in soil extracts from fan soils ranged from 525 to $8,600 \mathrm{mg} / \mathrm{L}$. The Bureau of Reclamation (1977b) reported that the gray soils have about 8 times more potential salt loading than do the red soils. Gray soils have limited profile development, have low permeability, and are erodible. In some areas of the MVIC, there are problems with irrigation on gray soils because of salinity and poor drainage. Gray soils are present in the southern and southeastern parts of Montezuma Valley (generally south of Mc Elmo Creek), and in the eastern Towaoc area (east of Cowboy Wash). Soils along the lower Mancos River Valley on the Ute Mountain Ute Reservation are similar to the gray soils because the Mancos Shale is extensive in this area. 
The red soils are residual soils derived from eolian deposits. Red soils are loam to clay loam in texture, have moderate depths over sandstone and shale, and have moderate to high permeability. The northeastern part of the MVIC area has a mixture of red and gray soils, but generally has loam to clay loam red soil overlying silty clay gray soil. Dissolved-solids concentrations in soil extracts from the northeastern part of the MVIC area ranged from 250 to $4,000 \mathrm{mg} / \mathrm{L}$ (Bureau of Reclamation, 1988). Runoff and deep percolation from red soils often enter areas where gray soils are present. Red soils are predominant in the MVIC area north of Mc Elmo Creek and west of Highway 666 (fig. 1). All irrigated land in the Dove Creek area is on red soils. Red soils also are present in the Towaoc area west of Cowboy Wash.

\section{Land Use}

The primary economic activity in the Dolores Project area is agriculture and its related services. Agricultural uses are concentrated on livestock grazing, feed crops, and rangeland. Primary crops are alfalfa, hay, pasture, small grains, feed corn, and some vegetables and fruit. Historically, dryland farming in the Dove Creek area produced pinto beans, alfalfa, and wheat. Prior to 1993, the primary land use on the Ute Mountain Ute Reservation was for cattle and sheep grazing. Along the Mancos River, the Ute Mountain Ute Tribe irrigates about 200 to 300 acres for growing cattle feed and pasture; however, the largest agricultural development on the reservation will occur when water is delivered to the Towaoc area by the Dolores Project.

The Dolores Project area has a small population. The following population statistics are from the 1990 census (Rand McNally and Company, 1993). Montezuma County had a population of 18,672 . The only area that may be considered an urban area is Cortez (population 7,284). The other towns are small farming communities, such as Dove Creek (population 643) and Dolores (population 866). Towaoc, headquarters of the Ute Mountain Ute Tribe, had a population of 700 .

Oil and gas drilling have historically been an important economic factor and source of employment in the Four Corners area. There is little drilling activity and no uranium or coal activity in Montezuma County (U.S. Bureau of Land Management, Durango, Colorado, oral commun., 1989). Metal mining, primarily for gold and silver, began in the upper Dolores River basin in the 1870's. Presently (1993), there are no gold-mining activities in the basin. Mine drainage could be a potential source of heavy metals in the irrigation water supply from the Dolores River. Recreation and tourism have become an important part of the economy in the region. The Dolores Project area is adjacent to many attractions, and tourism has increased steadily in the last few years. McPhee Reservoir attracts people for recreation, such as fishing and boating.

Natural vegetation in the Dolores Project area is dominated by pinyon pine and juniper, which are scattered throughout the area, and sagebrush. In lower, drier areas, salt shrubs such as greasewood are present. Higher and wetter areas grade into oak brush and pine forests. Vegetation is relatively sparse on lower areas of the Ute Mountain Ute Reservation. The valley bottoms have pasture interspersed with brush and marshes. Along streams, riparian vegetation is predominately cottonwood and boxelder trees interspersed with dense brush and shrubs.

\section{Fish and Wildlife Resources}

There are several fish and wildlife resource areas within the Dolores Project area that could be affected by irrigation. The State of Colorado manages several State wildlife areas of nongame and game species of fish and wildlife. State wildlife areas in the project area are Narraguinnep Reservoir, Totten Reservoir, and the Dolores River downstream from McPhee Reservoir. Wildlife enhancement for the Dolores Project was planned in Dawson Draw (fig. 1).

Narraguinnep and Totten Reservoirs contain a variety of warm-water game fish and are used as waterfowl nesting and resting areas. The Dolores River downstream from McPhee Dam is an excellent coldwater trout fishery, and the Dolores River Canyon has mule deer, elk, and wild turkey. The canyon area also provides a wintering area for waterfowl because of warm water downstream from the dam during winter. There are numerous small ponds and wetlands in the MVIC and Dove Creek areas that are used by migratory waterfowl. Fish and wildlife resource areas are very limited at low elevations on the Ute Mountain Ute Reservation. The Mancos River is not considered an important fishery; however, the river is one of the few streams in Colorado populated only by native fish species. Wetland areas are limited in the Towaoc area, and there is little utilization of this area by migratory waterfowl.

Recently (1987), endangered fish species have been documented in the San Juan River from near Shiprock, New Mexico to Lake Powell (fig. 2). The federally listed endangered Colorado squawfish (Ptychocheilus lucius) was identified in 1987 and 1988 in the San Juan River (Meyer and Moretti, 1988; Roberts and Moretti, 1989). Young-of-the-year fish were seined from the river, indicating that Colorado squaw- 
fish reproduced in the San Juan River. Adult razorback suckers, another federally listed endangered species, were captured in the San Juan arm of Lake Powell.

Two endangered birds, the bald eagle and the peregrine falcon, are present in the Dolores Project area. Bald eagles winter in Colorado and typically roost near open water where they feed on fish. Fish are a potential source of contamination to bald eagles. There is at least one pair of peregrine falcons nesting in the Mesa Verde National Park area; these falcons probably feed on other birds in the Dolores Project area. There are two federally listed endangered plants occurring in or near irrigated areas, the Mancos milkvetch (Astragalus humillimus) and the Mesa Verde cactus (Sclerocatus mesae-verdae). In addition, three candidate plant species for listing as endangered species are found in the project area.

In May 1991, fish consumption advisories were posted by the Colorado Division of Wildlife, in cooperation with the Colorado Department of Health, at McPhee and Narraguinnep Reservoirs. The advisories were posted because some warm-water game fish, such as walleye, northern pike, and bass from the reservoirs had elevated concentrations of mercury. The mercury concentrations did not pose an acute hazard, but there was concern about chronic, long-term exposure to small amounts of mercury, especially for children and pregnant women (Colorado Department of Health, 1992).

\section{HYDROLOGIC SETTING}

The hydrologic system of the Dolores Project area is complex and includes two major tributaries of the Colorado River (fig. 2), the Dolores River (source of irrigation water) and the San Juan River (receives all irrigation drainage and return flow). The San Juan River upstream from the confluence of the Mancos River to downstream from the confluence of Mc Elmo Creek, the Mancos River, Mc Elmo Creek, and tributaries are included in the hydrologic system. Also included in the hydrologic system are the canyons north of the Mc Elmo Creek basin that drain into Montezuma Creek, which discharges to the San Juan River in Utah (fig. 1). A general schematic of the surfacewater system is shown in figure 3 . The irrigation systems and ground water are other components of the hydrologic system of the Dolores Project area.

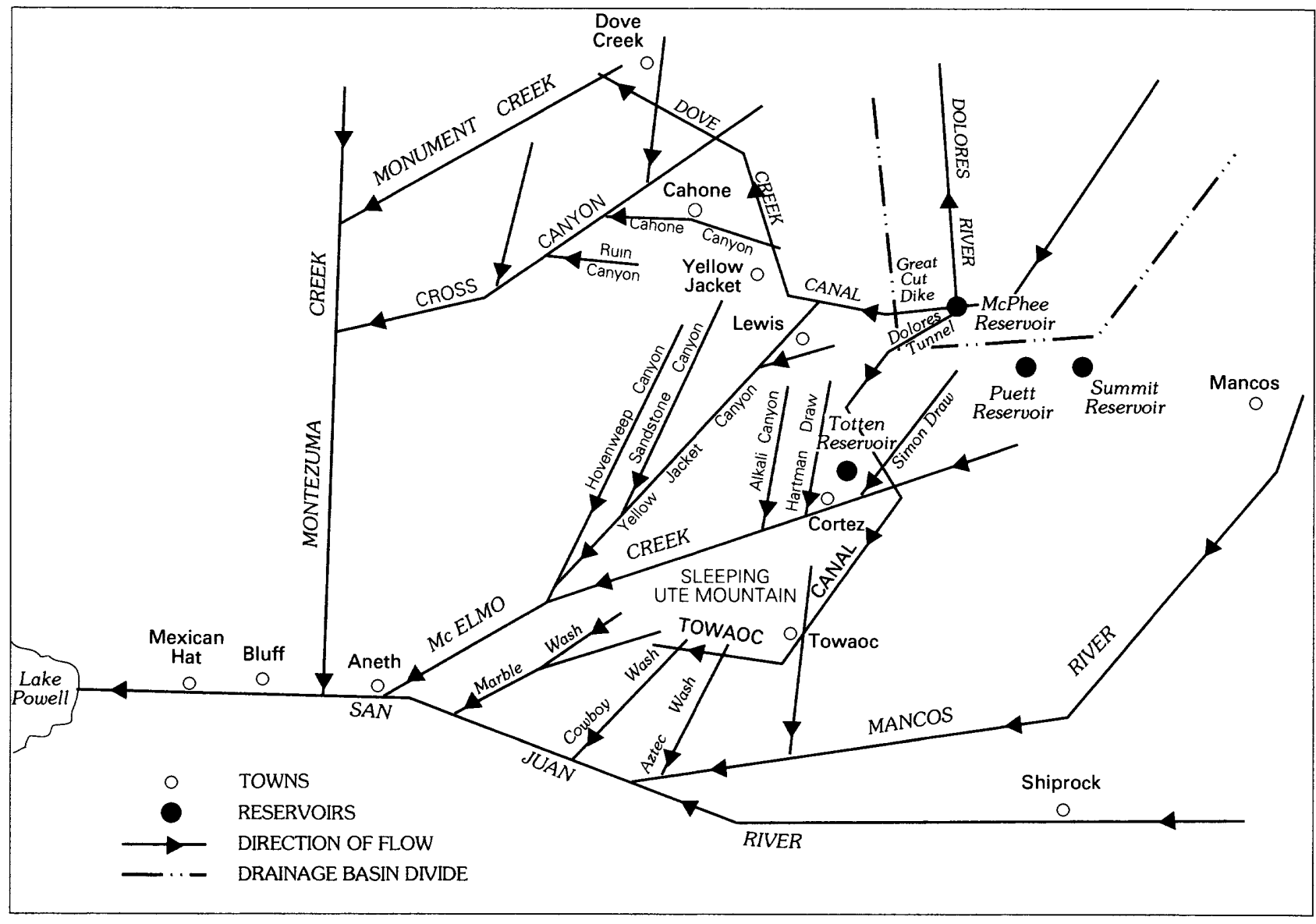

Figure 3. Major streams, tributaries, reservoirs, canals, and movement of water in the Dolores Project area. 


\section{Surface Water}

The San Juan River drains about $24,600 \mathrm{mi}^{2}$ and heads in the San Juan Mountains about $100 \mathrm{mi}$ east of Cortez, flowing generally west to southwest to Lake Powell in Utah (fig. 2). The U.S. Geological Survey operates a streamflow-gaging station at Mexican Hat, Utah (gaging station 09379500; site SJ3 in fig. 2), and that station is the most downstream gaging station on the river. The drainage area upstream from gaging station 09379500 is about $23,000 \mathrm{mi}^{2}$. The average annual mean discharge for water years 1962-89 was $2,258 \mathrm{ft}^{3} / \mathrm{s}$. The flow regime of the San Juan River has been altered since completion of Navajo Reservoir in 1962. Based on information from the U.S. Department of the Interior (1989), the San Juan River accounted for about 15 percent of the inflow into Lake Powell for water years 1976-87. Except for rainfall-induced peaks during the summer, stream discharge of the San Juan River generally was less than normal (compared to water years 1962-89) prior to and during the reconnaissance investigation in 1990 (fig. 4). Water year 1990 was the third consecutive year of less-than normal stream discharge in the San Juan River at gaging station 09379500 (fig. 5); the annual mean discharge for water year 1990 was only 47 percent of the average annual mean discharge for water years 1962-89. The U.S. Geological Survey has operated a gaging station at Four Corners (gaging station 09371010; site SJ1 in fig. 1) since 1978. The drainage area upstream from that gaging station is $14,600 \mathrm{mi}^{2}$. The average annual mean discharge for water years 1978-89 was $2,684 \mathrm{ft}^{3} / \mathrm{s}$, which is about 94 percent of the average annual mean discharge $\left(2,858 \mathrm{ft}^{3} / \mathrm{s}\right)$ at gaging station 09379500 for the same period. That small difference of annual stream discharges indicates that runoff per unit drainage area in the San Juan River basin between the two gaging stations is small.

The Dolores River originates in the San Juan Mountains northeast of the Dolores Project area, flows southwest, and then turns abruptly at the town of Dolores to flow northwest to its confluence with the Colorado River about $75 \mathrm{mi}$ north of Dove Creek (fig. 2). The U.S. Geological Survey has operated a streamflow-gaging station at Dolores (drainage area $504 \mathrm{mi}^{2}$ ), immediately upstream from McPhee Reservoir, since 1922. The average annual mean discharge for the Dolores River at Dolores for water years 1922-89 was $445 \mathrm{ft}^{3} / \mathrm{s}$.

Mc Elmo Creek drains $702 \mathrm{mi}^{2}$ and heads on the low drainage divide northeast of Cortez and flows generally west to the San Juan River at Aneth, Utah (fig. 2).
The U.S. Geological Survey operated two streamflowgaging stations on Mc Elmo Creek, gaging station 09371500 (at site ME2 in fig. 1) and gaging station 09372000 (at site ME3 in fig. 1). Gaging station 09372000 near the Colorado-Utah State line (drainage area $346 \mathrm{mi}^{2}$ ) has been operated since 1951. The hydrograph for the period of record for gaging station 09372000 (fig. 6) does not indicate a distinct seasonal pattern, which is atypical of streams in this area. Much of the stream discharge in Mc Elmo Creek is return flow and irrigation drainage from the MVIC area. Stream discharge in Mc Elmo Creek was less than normal (water years 1952-89) from October 1989 to June 1990 and at or greater than normal from July to November 1990 (fig. 6). The large discharge peaks in the summer of 1990 were caused by thunderstorms and rainstorms. The annual mean discharge at gaging station 09372000 for water year 1990 was about 74 percent of the average annual mean discharge for water years 1952-89.

The Mancos River drains about $795 \mathrm{mi}^{2}$ and heads into the San Juan Mountains northeast of the town of Mancos (fig. 1) at elevations above $10,000 \mathrm{ft}$. The river flows southwest to south to its confluence with the San Juan River south of the ColoradoNew Mexico State line. The confluence is a few miles upstream from streamflow-gaging station 09371010 on the San Juan River. Stream-discharge data have been collected for the Mancos River at Highway 666 at gaging station 09371000 (at site MN1 in fig. 1) (drainage area $526 \mathrm{mi}^{2}$ ). The headwater areas of the Mancos River are considerably higher than the headwater areas of Mc Elmo Creek, therefore, snowmelt runoff normally is substantially greater in the Mancos River basin. Also, there is no transbasin import of water into the Mancos River basin as there is in the Mc Elmo Creek basin. The mean annual discharge for water year 1990 was only 20 percent of the average mean annual discharge for water years 1952-89 at gaging station 09371000 , primarily because spring runoff was much less than normal in 1990.

A hydrologic study of Cottonwood Wash (drainage area $\left.16 \mathrm{mi}^{2}\right)$, a tributary of Navajo Wash, was done by Geldon (1985). Stream discharge of Cottonwood Wash probably is typical of intermittent washes and streams in the Dolores Project area that are not affected by irrigation drainage. The average annual mean discharge (water years 1980-82) was less than $0.2 \mathrm{ft}^{3} / \mathrm{s}$, and there often was no flow in the wash during the summer. 


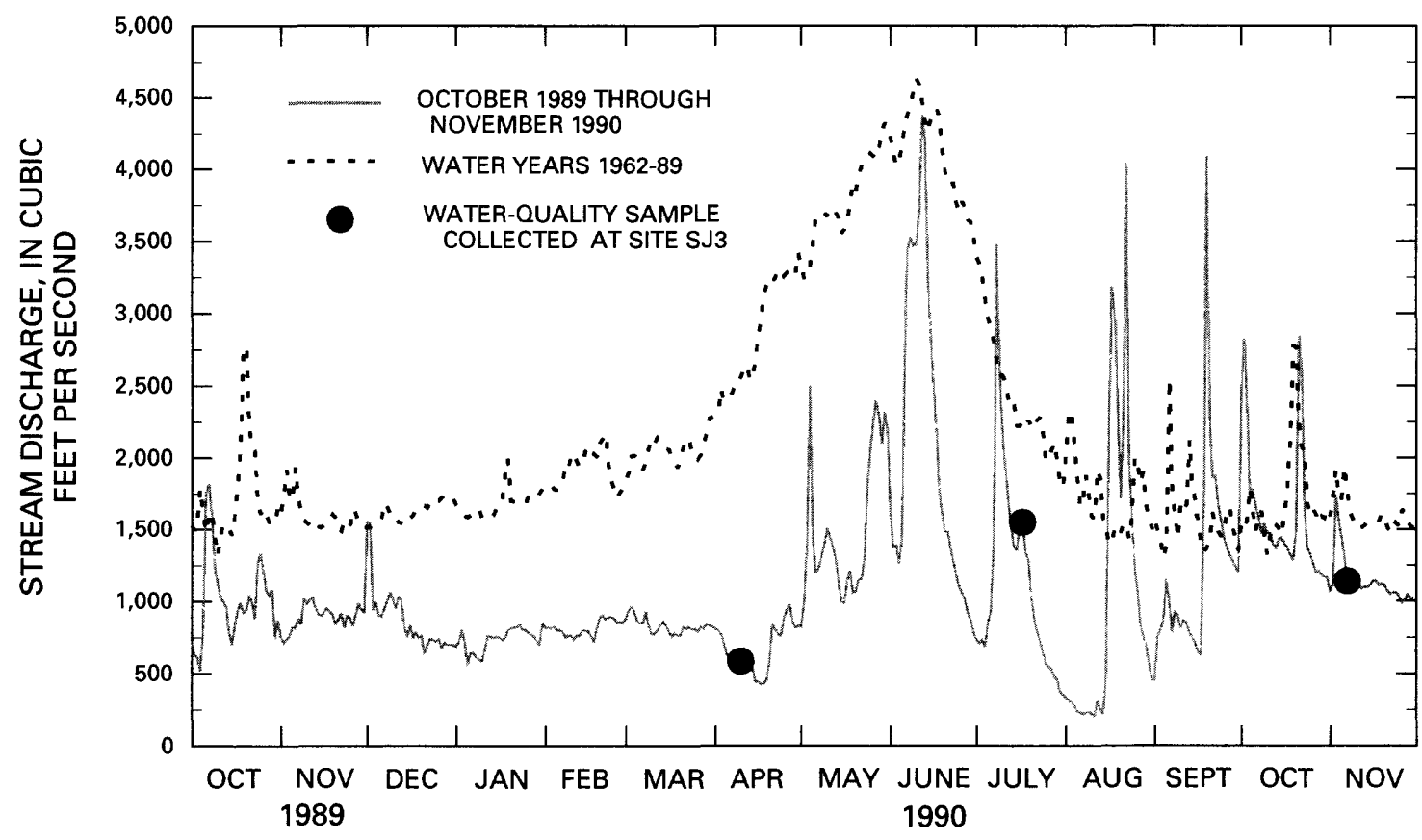

Figure 4. Daily mean stream discharge for October 1989 through November 1990 , average daily mean stream discharge for water years 1962-89, and dates when water-quality samples were collected at streamflow-gaging station 09379500, San Juan River at Mexican Hat, Utah (site SJ3).

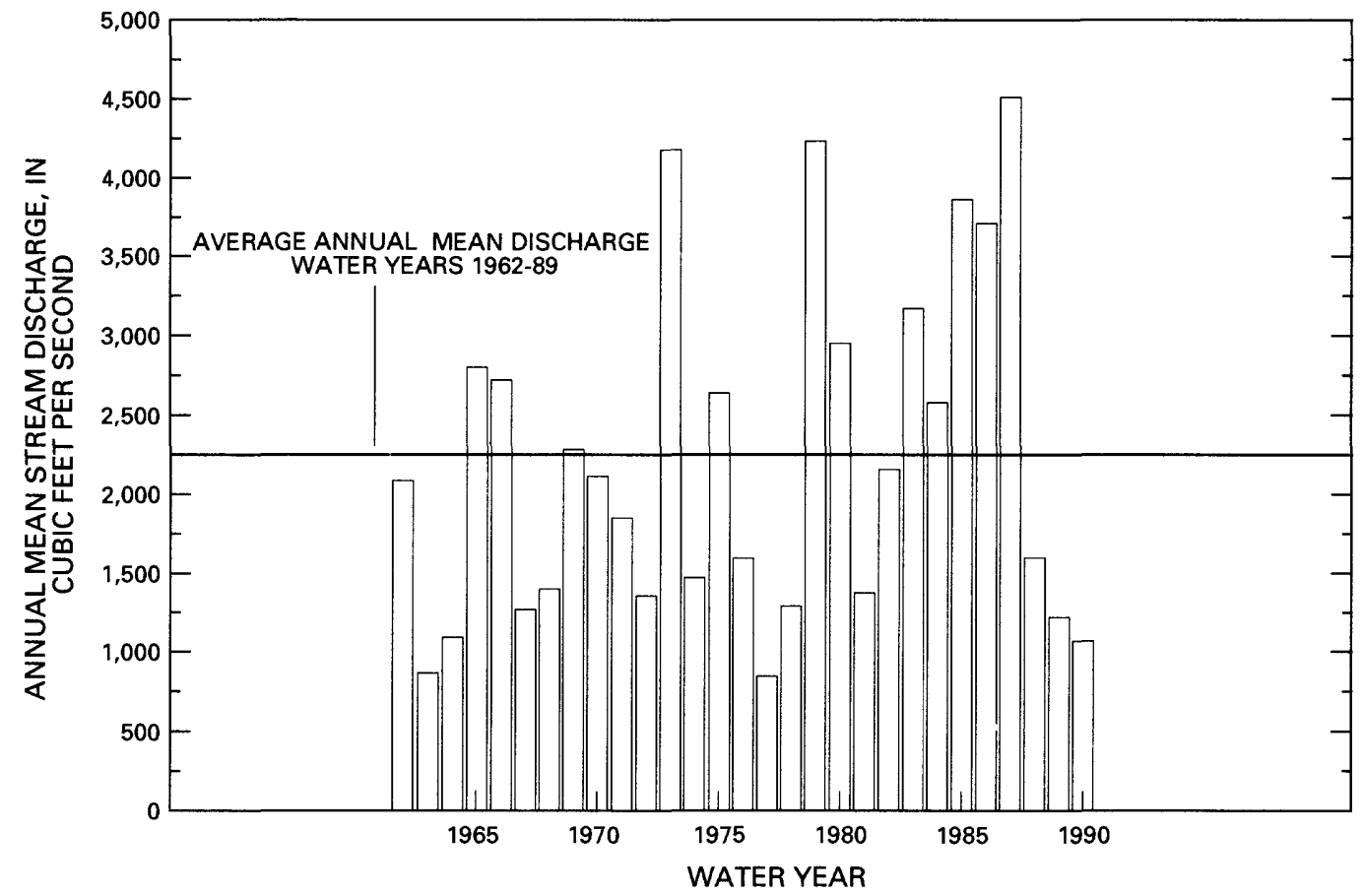

Figure 5. Annual mean stream discharge at streamflow-gaging station 09379500 , San Juan River at Mexican Hat, Utah (site SJ3), water years 1962-90. 


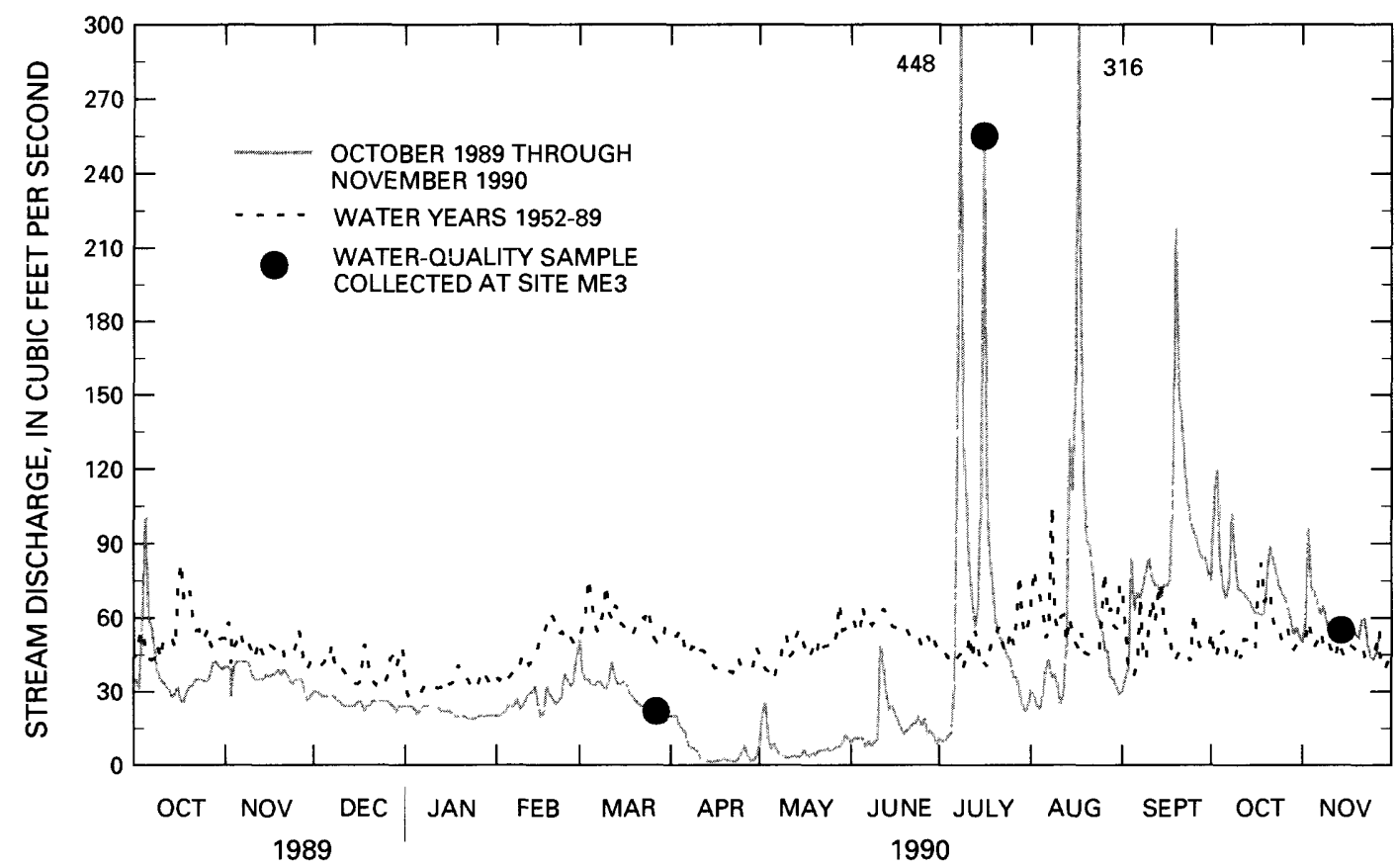

Figure 6. Daily mean stream discharge for October 1989 through November 1990 , average daily mean stream discharge for water years $1952-89$, and dates when water-quality samples were collected at streamflow-gaging station 09372000, Mc Elmo Creek near the Colorado-Utah State line (site ME3).

\section{Irrigation Projects}

Four irrigation projects will be described in this section. Most of the discussion is about the Dolores Project. Brief descriptions also are given for the Ute Mountain Ute Irrigation Project, the Mancos Project, and the Summit Irrigation District.

\section{Dolores Project}

The Dolores Project develops water from the Dolores River for irrigation, municipal and industrial use, power production, recreation, and fish and wildlife enhancement. Other project purposes include flood control, salinity control, and cultural resources mitigation. The MVIC furnishes water to about 37,500 acres, and the Dolores Project supplies supplemental water to the MVIC system for irrigation of 26,300 acres. There are 11,200 acres of land served by MVIC that will not receive project water because the soils were classified as unsuitable for irrigation (Bureau of Reclamation, 1977a). The Dolores Project will irrigate 27,920 acres in the Dove Creek area and 7,500 acres in the Towaoc area (fig. 1). The Dove Creek and Towaoc areas will be irrigated for the first time. Through August 1991, about 18,000 acres in the Dove Creek area had been brought into irrigation as sections of the Dove Creek Canal and laterals were completed.
The Dolores Water Conservancy District (DWCD) is responsible for general operation and administration of all project facilities. The Bureau of Reclamation and DWCD signed an agreement in 1985 for DWCD to operate and maintain the project with Bureau of Reclamation supervision. The MVIC will continue to administer its system, including the salinity-control modifications to be built for the Dolores Project. The Ute Mountain Ute Tribe will be responsible for operation and maintenance of the canals and laterals to the Towaoc area.

The primary components of the Dolores Project include McPhee Reservoir (capacity 381,000 acre-ft), the Dolores Tunnel, Great Cut Dike, Dove Creek Canal, Towaoc Canal, and six pumping plants. Other components include laterals, power plants, drainage facilities, and salinity-control features (canal lining and pipe laterals). Major features are shown in relation to the hydrologic system in the schematic in figure 3. McPhee Reservoir was completed in 1984. The Dolores Tunnel replaces the old tunnel from the Dolores River operated by MVIC. Water from McPhee Reservoir is transported through the Great Cut Dike into the Dove Creek Canal and into the northern part of the MVIC system. The Dove Creek Canal and laterals in the Dove Creek area were completed by August 1991. Water deliveries from the Dove Creek Canal began in the Cahone and Yellow Jacket areas in 1987, 
and delivery of the supplemental water to the MVIC system began in 1988. Water deliveries to the Dove Creek area and the acreage of newly irrigated land for 1987-90 are summarized in table 1 . Since completion of the Dove Creek Canal in 1991, irrigation in the Dove Creek area has gradually increased as the distribution system was completed and more farmers began using Dolores Project water. As of September 1993, there was about 7,000 acre-ft of project water yet to be utilized in the Dove Creek area.

Table 1. Water delivery and irrigated acreage in the Dove Creek area of the Dolores Project, 1987-90

\begin{tabular}{ccc}
\hline Year & $\begin{array}{c}\text { Water delivered } \\
\text { (acre-feet) }\end{array}$ & $\begin{array}{c}\text { Irrigated acreage } \\
\text { (acres) }\end{array}$ \\
\hline 1987 & 2,100 & 1,050 \\
1988 & 8,800 & 4,400 \\
1989 & 16,000 & 8,000 \\
1990 & 26,600 & 13,300 \\
& & \\
Full allocation & 54,300 & 27,920 \\
\hline
\end{tabular}

The Towaoc Canal, completed in September 1993, will serve the newly irrigated land in the Towaoc area on the Ute Mountain Ute Reservation and serves part of the MVIC service area. Some laterals and center pivots were in use in 1993 in the Towaoc area, and about 1,000 acres were irrigated. Completion of laterals on the Ute Mountain Ute Reservation is planned in 1994.

Narraguinnep and Totten Reservoirs (fig. 1) are storage reservoirs from the old MVIC system. Narraguinnep Reservoir (capacity 19,000 acre-ft) is an offstream reservoir located about $10 \mathrm{mi}$ north-northwest of Cortez and was supplied by the old MVIC tunnel and canal system. Totten Reservoir (capacity 3,000 acre-ft), located northeast of Cortez, will no longer be used by the MVIC system for storage of water for irrigation supplies once the Towaoc Canal and Rocky Ford lateral are completed. Totten Reservoir will be kept as a fishery, and 800 acre-ft of water from McPhee Reservoir are reserved for maintenance of water storage in Totten Reservoir.

Once completed, the Dolores Project will provide an average of $90,900 \mathrm{acre}-\mathrm{ft} / \mathrm{yr}$ of water from the Dolores River basin (from McPhee Reservoir) for irrigation in the San Juan River basin and 8,700 acre-ft/yr of water for municipal and industrial uses. The average annual irrigation allocations for the project are 13,700 acre-ft of supplemental water for the MVIC system, 54,300 acre-ft to the Dove Creek area, and 22,900 acre- $\mathrm{ft}$ to the Towaoc area (Bureau of Reclama- tion, 1977a). The MVIC will continue to receive its historical diversion of Dolores River water because MVIC water rights are senior to all project water rights. In an agreement with DWCD, MVIC will limit their demand to enable the project to have an adequate water supply; in exchange, the MVIC will receive the supplemental project water $(13,700 \mathrm{acre}-\mathrm{ft} / \mathrm{yr})$ to alleviate late-season shortages that were common pre-project occurrences. The average annual diversion through the old MVIC Tunnel from 1928-73 was about 105,000 acre-ft (Bureau of Reclamation, 1977a).

The MVIC will continue to use its gravity distribution system, which is old, and many of the canals and laterals are incised into shale. None of the MVIC distribution system was lined; however, part of the MVIC system will be replaced or rehabilitated for the salinitycontrol features of the Dolores Project. Sections of three laterals and canals were abandoned when the Towaoc Canal was built. Two ditches in the southern MVIC area were abandoned, and that area is now served by buried pipe laterals from the Towaoc Canal. The remaining salinity control work for the Dolores Project is lining $9.3 \mathrm{mi}$ of laterals in the northern MVIC area, and that work is expected to be completed by 1995.

The irrigation method used in most of the MVIC area is flood irrigation. Irrigators often have applied excess water early in the year during spring runoff to store sufficient soil moisture for use by crops during the late-season dry period when water supply often is insufficient. With the supplemental water from the Dolores Project, there will be more water available for late season use.

The Dove Creek and Towaoc Canals are open, earth-lined canals. Water is distributed from these canals through pressurized pipe laterals to sprinkler systems. Pressure is supplied by pumping plants in the Dove Creek area and by gravity in the Towaoc area.

Irrigation drainage in the MVIC area primarily is diffuse discharge into natural pathways, mostly ephemeral and intermittent streams, canyons, and arroyos. There are drainage problems in part of the MVIC area because of shallow depths to bedrock, low soil permeability, topography, and lack of natural drainages. Drainage facilities are limited in the MVIC system, and drainage facilities will not be constructed in the MVIC area for the Dolores Project. Surface return flow, natural runoff, and diffuse ground water (irrigation drainage) discharge into Mc Elmo Creek or its tributaries, such as Hartman Draw, Alkali Canyon, Trail Canyon, Yellow Jacket Canyon, and Dawson Draw (fig. 1). Irrigation drainage and return flow from the extreme southern MVIC area discharges into Navajo Wash, which is tributary to the Mancos River. 
As part of the Mc Elmo Unit Salinity Control Program, the Bureau of Reclamation (1981) estimated that return flow was about 35 percent of water applied in the MVIC area. If MVIC diverted their full allocation of water and received 13,700 acre-ft/yr of supplemental water, return flow would be about 50,500 acre- $\mathrm{ft} / \mathrm{yr}$. The salt load pickup from the Mc Elmo Creek basin is estimated at 117,900 tons/yr based on the latest project modifications (Bureau of Reclamation, 1989). Salt loading to the San Juan River from the Mc Elmo Creek basin is the result of distribution-system seepage and deep percolation of applied water that dissolves salts from soils and from the weathered zone of the Mancos Shale.

In the Dove Creek area (newly irrigated areas north of Yellow Jacket Canyon), drainage generally is not expected to be a problem except in low areas (Bureau of Reclamation, 1977b). Irrigation is or will be on ridge lands of rolling plateaus dissected by numerous swales and drainage pathways. All irrigation drainage is into Yellow Jacket, Hovenweep, Cross, and Squaw Canyons and into Monument Creek, or their tributaries (fig. 1). Natural drainage is expected to remove all excess surface water. Ground water is expected to accumulate in the low areas and swales, at the end of long slopes, and in isolated hillside seep areas where sandstone bedrock crops out at the surface. The low areas do not have sufficient subsurface drainage to remove the water because depths to sandstone or shale barriers often are shallow. The Bureau of Reclamation plans to install $24 \mathrm{mi}$ of deep pipe drains in the Dove Creek area to control the subsurface drainage and to protect low areas. The natural drainages will be used as collectors and outlets. The estimated volume of return flow is about 10,920 acre-ft/yr from the Dove Creek area (Bureau of Reclamation, 1977b).

Land to be irrigated in the Towaoc area is on relatively smooth, long, continuous slopes separated by major washes. Major washes are shown in figure 1 and include Aztec, Cowboy, Mariano, Coyote, and Marble Washes. Aztec Wash is tributary to the Mancos River; the other washes are tributary to the San Juan River. The washes are ephermal and have channels 10 to $50 \mathrm{ft}$ deep in their lower reaches. There are numerous washes and gullies tributary to the main washes that should provide adequate surface drainage.

The subsurface drainage in the Towaoc area varies because of different soils and bedrock (Bureau of Reclamation, 1977b). West of Mariano Wash, the areas to be irrigated are on red soils underlain by Dakota Sandstone. Pipe drains should provide adequate subsurface drainage west of Mariano Wash. The outlet and collectors would be the natural drainages, which in this area are eroded to the sandstone bedrock. Areas to be irrigated in Aztec Wash and Cowboy Wash are on gray soil underlain by Mancos Shale bedrock. The bottom of the natural drains are fine-textured gray soils, and the drains tend to constrict toward their lower ends. In addition to the pipe drains, the Towaoc area also will have a piped outlet system. The Bureau of Reclamation estimates that $49 \mathrm{mi}$ of deep pipe drains will be built in the Towaoc area.

The estimated volume of return flow would be about 4,930 acre- $\mathrm{ft} / \mathrm{yr}$ from the Towaoc area (Bureau of Reclamation, 1977b). An estimated 30,000 tons/yr of salt would enter into the San Juan River for the first 6 years of irrigation in the Towaoc area, and the salt load would average 12,600 tons/yr for 100 years. The dissolved-solids concentration is predicted to increase from $127 \mathrm{mg} / \mathrm{L}$ in applied water to $2,470 \mathrm{mg} / \mathrm{L}$ in return flows from the Towaoc area (Bureau of Reclamation, 1977b). Rapid leaching is expected in the red-soil areas west of Mariano Wash, and good quality return flows are expected after initial leaching.

\section{Ute Mountain Ute Irrigation Project}

The Ute Mountain Ute Irrigation Project consists of a single farm that irrigates land along the Mancos River immediately west of Highway 666. The project was planned to irrigate 563 acres, but has never irrigated more than 290 acres, and 205 acres were irrigated in 1988. Water for the Ute Mountain Ute Irrigation Project is diverted from the Mancos River about $2 \mathrm{mi}$ upstream from Highway 666 into a unlined ditch that runs north of the river. Water is applied by flood irrigation to fields of alfalfa, sudan grass, oats, and pasture. Drainage is through the natural pathways to the Mancos River. Surface runoff has not been measured or estimated; however, there may be little, if any, runoff from irrigated areas during a significant part of the irrigation season because of the limited water supply to this project. There are periods during the summer when there is no flow in the Mancos River upstream from the diversion.

Further development and expansion of this irrigation project is greatly restricted by several constraints and is not likely to occur. Constraints include limited water supply, topography, nonarable soils, and archaeological mitigation.

\section{Mancos Project}

The Mancos Project irrigates land in the Mancos River basin upstream from the Dolores Project area. Facilities built by the Bureau of Reclamation for the Mancos Project were for supplemental irrigation supply and for domestic water for the town of Mancos, the 
rural Mancos area, and for Mesa Verde National Park. The general extent of the irrigated area of the Mancos Project is in the vicinity of the town of Mancos (fig. 1). The irrigated area is about 13,746 acres; 11,683 acres were actually irrigated in 1981. Primary crops are alfalfa, hay, pasture, wheat, oats, barley, and feed corn. Storage is in Jackson Gulch Reservoir (capacity 9,980 acre-ft), located about 4 mi north of the town of Mancos (fig. 1). The reservoir was built in 1950 by the Bureau of Reclamation. Parts of the distribution system were built before 1900 .

The irrigated areas are in the Mancos River Valley to the east side of Mesa Verde National Park and in Weber Canyon (fig. 1). Some of the irrigated land is on alluvial areas, but the entire area in underlain by Mancos Shale. Drainage from the area is through the natural drainages and subsurface flow to the Mancos River. The effects of irrigation drainage from the Mancos Project on water quality of the Mancos River have not been studied.

\section{Summit Irrigation District}

The Summit Irrigation District is a private company that provides water for about 4,600 acres in the upper Mc Elmo Creek basin, upstream from the MVIC service area. The irrigated areas are located near and west of Summit and Puett Reservoirs (fig. 1). The district diverts water from the Dolores River basin from Lost Canyon Creek into Summit Reservoir.

The Summit Irrigation District has similar physiography, climate, geology, and soils as the Montezuma Valley. The irrigated area is at a slightly greater elevation (about 7,000 ft) than the Montezuma Valley; therefore, the area probably has a shorter growing season and receives more precipitation than Cortez. Crops are alfalfa, small grains, and pasture. The irrigated land is mostly on soils derived from the Dakota Sandstone and to a lesser extent, the Mancos Shale. Effects on water quality in the Mc Elmo Creek basin by irrigation drainage from the Summit District land are not known.

\section{Ground Water}

Ground water is present in several unconsolidated alluvial deposits (colluvium, pediments, stream alluvium) and in confined bedrock units. The aquifers in alluvial deposits have the best potential yields. In the Towaoc area (Geldon, 1985), yields as great as $\mathbf{5 0}$ to $100 \mathrm{gal} / \mathrm{min}$ were reported in talus and pediment deposits, but yields had large seasonal variation. The quantity of water stored in alluvial deposits also was quite variable. Geldon (1985) reported that bedrock in the area consisted of fine-grained material such as claystone, shales, sandstones, and mudstones, and although bedrock aquifers might contain considerable quantities of water, yields in these aquifers are insufficient for development.

Irwin (1966) described ground water on the Ute Mountain Ute Reservation and stated that the Mancos Shale is not a good aquifer because of low permeability and storage. Because the shale is thick and extensive, development of water supplies from ground water would be difficult. Yields from sandstone aquifers in the Dakota Sandstone were quite small on the Ute Mountain Ute Reservation, and limestone beds were too thin in the area to be major aquifers (Irwin, 1966). At the regional scale, water in shallow aquifers flows toward the canyons and tributaries of the San Juan River. Water in deeper bedrock aquifers flows toward the San Juan River (Whitfield and others, 1983).

The Bureau of Reclamation drilled about 70 wells from 1977-80 for ground-water investigations in the Mc Elmo Creek basin (Bureau of Reclamation, 1988). Ground water was present in surficial materials consisting of colluvium, gravels, and weathered shale and in the Dakota Sandstone. Ground-water flow generally was toward Mc Elmo Creek, and ground water in all areas seemed to be recharged by deep percolation from irrigation (Bureau of Reclamation, 1988).

Ground-water use in the Dolores Project area for domestic supplies is not significant. Spring water from the Cottonwood Wash basin was used to augment supplies for Towaoc. Towaoc now receives municipal water from the Cortez water-treatment plant. There are scattered water wells in rural areas that may be used for domestic and livestock water supplies, but the number of wells is not large nor is the water use significant when compared to the surface-water supplies.

\section{PREVIOUS INVESTIGATIONS}

The Bureau of Reclamation has done extensive hydrologic, water-supply, irrigation-drainage, geologic, and soils investigations for planning reports and for environmental impact statements for the Dolores Project (Bureau of Reclamation, 1977a,b, 1988, 1989). The Bureau of Reclamation also has investigated water quality of the Mc Elmo Creek basin for the Mc Elmo Creek Unit of the Colorado River Water Quality Improvement Program (Bureau of Reclamation, 1981). The Mc Elmo Creek Unit, a salinity control project, is now a feature of the Dolores Project (Bureau of Reclamation, 1988, 1989). Many geologic and mineralrelated (uranium, coal, oil, and natural gas) studies have been done in the Four Corners area (such as Fassett and Hinds, 1971; Ridgley and others, 1978). 
Studies related to uranium generally were outside of the Dolores Project because the major economic deposits are outside the area. The U.S. Geological Survey and other investigators have done numerous geologic and ground-water investigations in the San Juan basin (Stone and others, 1983; Weir and others, 1983; Whitfield and others, 1983). Many of the studies of the San Juan basin were in New Mexico or in coal areas in Colorado, east of the Dolores Project area.

Other than the studies done by the Bureau of Reclamation, investigations specific to the Dolores Project area are limited. Geldon (1985) discussed water supply for Towaoc and the geohydrology of the Cottonwood Wash basin, a tributary to Navajo Wash. Water supply and geology of the Ute Mountain Ute Reservation was investigated by Irwin (1966). An inventory of soil and rangeland on the Reservation was reported by the Bureau of Indian Affairs (1965). The Colorado Department of Game, Fish, and Parks (former name of the Colorado Division of Wildlife) surveyed the upper Dolores River basin from 1960 to 1968 to address contamination problems caused by tailings ponds and a sulfuric acid plant (State of Colorado, 1968). The Bureau of Reclamation has done recent investigations in the Dolores River basin concerning sources of mercury. Recently (since about 1987), there have been several biological investigations in the Dolores Project area by the Colorado Division of Wildlife, Bureau of Reclamation, the U.S. Fish and Wildlife Service, and the National Park Service.

\section{Water-Quaiity Data}

\section{Surface Water}

Water-quality data collected in the Mc Elmo Creek basin by the Bureau of Reclamation were for studies of salt loading, and trace-element data were not collected. The U.S. Geological Survey collected traceelement data between 1977-81 at streamflow-gaging station 09372000, Mc Elmo Creek near the ColoradoUtah State line (site ME3 in fig. 1), and those data are summarized in table 2. A computer retrieval from the U.S. Environmental Protection Agency's Storage and Retrieval system (STORET) located 60 selenium analyses of water samples collected from Mc Elmo Creek west of Cortez. These selenium data were collected by the Colorado Department of Health; the median concentration was $5 \mu \mathrm{g} / \mathrm{L}$ and the maximum concentration was $20 \mu \mathrm{g} / \mathrm{L}$. Trace-element data for tributaries of Mc Elmo Creek are very limited. The U.S. Bureau of Land Management collected three samples from Yellow Jacket Canyon in 1983 and 1984 (Dennis Murphy,
U.S. Bureau of Land Management, written commun., 1989). Selenium concentrations in those three samples were 4,2 , and $10 \mu \mathrm{g} / \mathrm{L}$, and concentrations of arsenic, cadmium, mercury, silver, and zinc were about equal to or less than analytical reporting limits.

Table 2. Median and maximum concentrations of trace elements in water samples collected at streamflow-gaging station 09372000, Mc Elmo Creek near the Colorado-Utah State line (site ME3)

[Analyses by U.S. Geological Survey; dissolved constituents unless noted; concentrations in micrograms per liter; $<$, less than]

\begin{tabular}{lccc}
\hline Trace olement & $\begin{array}{c}\text { Number of } \\
\text { samples }\end{array}$ & Medlan & Maxlmum \\
\hline Arsenic & 15 & 1 & 3 \\
Arsenic, total & 8 & 2 & 10 \\
Barium & 15 & 30 & 200 \\
Boron & 46 & 200 & 310 \\
Cadmium & 15 & $<2$ & 6 \\
Cadmium, total & 8 & $<2$ & 1 \\
Chromium & 15 & $<20$ & 20 \\
Copper & 15 & $<20$ & 20 \\
Iron & 45 & 30 & 370 \\
Lead & 15 & $<10$ & 5 \\
Manganese & 15 & 110 & 280 \\
Mercury, total & 8 & $<.1$ & .3 \\
Molybdenum & 15 & 2 & 14 \\
Nickel & 15 & 3 & 15 \\
Selenium & 15 & 7 & 15 \\
Selenium, total & 8 & 4 & 33 \\
Vanadium & 15 & $<6$ & 14 \\
Zinc & 15 & 14 & 50 \\
Zinc, total & 8 & 30 & 760 \\
\hline & & & \\
\hline & 15 & 30 & 3 \\
\hline
\end{tabular}

The U.S. Geological Survey collected a single water sample from near the bottom (48-ft depth) of Narraguinnep Reservoir in July 1990. Concentrations of trace elements, including selenium, were not large, and many concentrations were less than analytical reporting limits.

Trace-element data were collected in the Mancos River basin. Except for the data collected by Geldon (1985) in the Navajo Wash basin, almost all of the data were collected upstream from the Dolores Project area (upstream from site MN1 in fig. 1). The U.S. Geological Survey collected water-quality data at the streamflow-gaging station at site MN1, but almost all the trace-element data were for iron and manganese. One sample had analyses for selenium; the concentration of total selenium was $7 \mu \mathrm{g} / \mathrm{L}$, and dissolved selenium was 
$3 \mu \mathrm{g} / \mathrm{L}$. Trace-element data were collected by the Colorado Department of Health from the Mancos River near Mancos; concentrations of arsenic (37 samples) ranged from 0 to $10 \mu \mathrm{g} / \mathrm{L}$, and selenium concentrations (24 samples) ranged from 0 to $5 \mu \mathrm{g} / \mathrm{L}$. Mercury was not detected in the nine samples that were analyzed for mercury. The maximum selenium concentration for a surface-water site reported by Geldon (1985) was $8 \mu \mathrm{g} / \mathrm{L}$ at Navajo Wash near the mouth.

The U.S. Geological Survey collected traceelement data for the San Juan River at streamflowgaging stations 09371010 (site SJ1 in fig. 1) and 09379500 (site SJ3 in fig. 2). These data are summarized in table 3. Most of the data for gaging station 09371010 were collected during 1977-81, and for gaging station 09379500 during $1975-89$. A retrieval from STORET for the San Juan River from Four Corners to Lake Powell located limited trace-element data collected by other agencies. There were 42 selenium analyses for the San Juan River near Four Corners collected by the Colorado Department of Health; the median concentration was $0 \mu \mathrm{g} / \mathrm{L}$, and the maximum concentration was $14 \mu \mathrm{g} / \mathrm{L}$. The Utah Department of Health has collected water-quality data for the San Juan River near the confluence with Montezuma Creek, Utah (fig. 2). Median concentrations of arsenic, cadmium, lead, selenium, and zinc were $0 \mu \mathrm{g} / \mathrm{L}$ (number of samples ranged from 31 to 42). The maximum concentration of selenium was $16 \mu \mathrm{g} / \mathrm{L}$ for the samples collected from the San Juan River at Montezuma Creek, and seven concentrations exceeded $5 \mu \mathrm{g} / \mathrm{L}$.

Trace-element data were collected by the Bureau of Reclamation in the Dolores River basin during 1969-75 and from the Dolores River at Dolores since 1979. Arsenic, cadmium, and lead concentrations generally were equal to or less than analytical reporting limits, and most samples had less than $2 \mu \mathrm{g} / \mathrm{L}$ of selenium. Mercury has been detected consistently in the water samples collected at Dolores, and several samples had total-mercury concentrations of 1 to $2 \mu \mathrm{g} / \mathrm{L}$.

Table 3. Median and maximum concentrations of trace elements in water samples collected at streamflow-gaging stations 09371010, San Juan River at Four Corners (site SJ1), and 09379500, San Juan River at Mexican Hat, Utah (site SJ3)

[Analyses by U.S. Geological Survey; dissolved constituents unless noted; concentrations in micrograms per liter; <, less than]

\begin{tabular}{|c|c|c|c|c|c|c|}
\hline \multirow[b]{2}{*}{ Trace element } & \multicolumn{3}{|c|}{ Gaging station 09371010} & \multicolumn{3}{|c|}{ Gaging station 09379500} \\
\hline & $\begin{array}{c}\text { Number of } \\
\text { samples }\end{array}$ & Median & Maximum & $\begin{array}{c}\text { Number of } \\
\text { samples }\end{array}$ & Median & Maximum \\
\hline Arsenic & 15 & 1 & 3 & $\overline{64}$ & 1 & 5 \\
\hline Arsenic, total & 10 & 2 & 40 & 32 & 3 & 180 \\
\hline Barium & 15 & 80 & 200 & 43 & 94 & 500 \\
\hline Boron & 46 & 90 & 290 & 144 & 80 & 520 \\
\hline Cadmium & 15 & $<2$ & 4 & 64 & $<1$ & 4 \\
\hline Cadmium, total & 10 & $<2$ & 9 & 33 & $<20$ & 20 \\
\hline Chromium & 15 & $<10$ & 10 & 64 & $<1$ & 10 \\
\hline Copper & 15 & 3 & 18 & 64 & 3 & 11 \\
\hline Iron & 46 & 20 & 120 & 59 & 15 & 410 \\
\hline Lead & 15 & $<10$ & 27 & 63 & 1 & 63 \\
\hline Manganese & 25 & 3 & 30 & 61 & $<10$ & 190 \\
\hline Mercury & 13 & $<.1$ & .2 & 64 & $<.1$ & 2.4 \\
\hline Mercury, total & 10 & $<.1$ & .8 & 31 & .1 & 2.2 \\
\hline Molybdenum & 13 & $<10$ & 4 & 30 & $<10$ & 10 \\
\hline Nickel & 15 & $<2$ & 3 & 36 & 1 & 10 \\
\hline Selenium & 15 & 2 & 6 & 64 & 2 & 7 \\
\hline Selenium, total & 10 & 3 & 9 & 32 & 3 & 27 \\
\hline Vanadium & 13 & $<6$ & 1 & 31 & $<6$ & 6 \\
\hline Zinc & 15 & 9 & 30 & 64 & 20 & 430 \\
\hline Zinc, total & 10 & 60 & 8,800 & 33 & 70 & 1,700 \\
\hline
\end{tabular}


The only pesticide data for water for the Dolores Project area were three samples collected from the San Juan River at Mexican Hat, Utah in 1977, 1978, and 1982. These samples were analyzed for organophosphate and phenoxyacid herbicides and organochlorine insecticides. The only pesticide detected was diazinon (concentration $0.01 \mu \mathrm{g} / \mathrm{L}$ ) in one sample.

\section{Ground Water}

Trace-element data for shallow ground water in the Dolores Project area are limited. A retrieval from the U.S. Geological Survey's National Water Information System (NWIS) located 17 samples that have dissolved-selenium data. The median dissolved-selenium concentration was $5 \mu \mathrm{g} / \mathrm{L}$, and the maximum concentration was $13 \mu \mathrm{g} / \mathrm{L}$ in samples from an alluvial spring near Sleeping Ute Mountain and from a spring in the Mancos Shale in the Navajo Wash basin upstream from Towaoc. A sample from an alluvial well (depth $65 \mathrm{ft}$ ) in Navajo Wash south of Towaoc had $12 \mu \mathrm{g} / \mathrm{L}$ of dissolved selenium. These data also were reported by Geldon (1985). The retrieval from NWIS also located two samples collected in 1973 from wells in the Dakota Sandstone in the Dove Creek area. Total-selenium concentrations in the samples were $36 \mu \mathrm{g} / \mathrm{L}$ for a well located near Yellow Jacket and $2 \mu \mathrm{g} / \mathrm{L}$ for a well located about $5.5 \mathrm{mi}$ west-northwest of Pleasant View. Based on a NWIS retrieval of selenium data for the Dakota Sandstone for a five-county area, the selenium concentration of $36 \mu \mathrm{g} / \mathrm{L}$ is not typical of selenium concentrations in water samples from the Dakota Sandstone in southwestern Colorado.

The Bureau of Reclamation collected water samples from 35 shallow wells in the MVIC area in 1978-80 (Bureau of Reclamation, 1988). The samples were analyzed for major ions and dissolved solids, but not for trace elements. The mean dissolved-solids concentration for 16 wells in red soil areas was $3,014 \mathrm{mg} / \mathrm{L}$, and the mean concentration for 19 wells in gray soil areas was $9,338 \mathrm{mg} / \mathrm{L}$ (Bureau of Reclamation, 1988). Ground water in red soil areas was a calcium magnesium sulfate type, and ground water in gray soil areas was a sodium magnesium sulfate type (Bureau of Reclamation, 1988).

In 1986, the Bureau of Reclamation started drilling an observation-well network in areas to be irrigated in the Dove Creek area. These were shallow wells, generally less than $20-\mathrm{ft}$ deep. The purpose of the wells was to monitor water levels in newly irrigated areas to identify areas where installation of subsurface drains may be needed. Through 1991, the Bureau of Reclamation had collected water-level data from 49 wells.
During 1991, 41 wells were monitored, and 23 were dry most or all of the year. Sixteen wells had water levels less than $5 \mathrm{ft}$ below land surface, and 12 wells had water levels greater than $10 \mathrm{ft}$ below land surface (Kenneth J. Ouellette, Bureau of Reclamation, written commun., 1992).

\section{Soil and Bottom-Sediment Data}

The Bureau of Reclamation has collected considerable soil data for the Dolores Project for classification of the soils regarding suitability for irrigation. Prior to 1987, soil analyses were physical tests and tests for salinity. In 1987, the Bureau of Reclamation collected soil samples at four locations in Dawson Draw (near site DD in fig. 1) for trace-element analyses (table 4). The maximum selenium concentration of $17.1 \mu \mathrm{g} / \mathrm{g}$ for Dawson Draw soil samples (table 4) seems to be an anomaly when compared to selenium concentrations in the other soil samples collected in 1987 and to selenium concentrations in bottom sediment collected in 1990. In 1989, the Bureau of Reclamation collected soil samples for selenium analysis in areas to be irrigated on the Ute Mountain Ute Reservation. Samples were collected at various depths at two sites near Aztec Wash (gray soil), one site near Mariano Wash (red soil), one site between Coyote and Marble Washes (red soil), and at two sites near Marble Wash (red soil). Selenium concentrations in the samples from gray soil ranged from 0.2 to $1.3 \mu \mathrm{g} / \mathrm{g}$, and concentrations in samples from the red soil areas ranged from 0.1 to $0.6 \mu \mathrm{g} / \mathrm{g}$. The soil sample that had $1.3 \mu \mathrm{g} / \mathrm{g}$ selenium was collected at a depth of 42- to 58-in. at one of the sites near Aztec Wash.

Table 4. Maximum and minimum concentrations of selected trace elements in four soil samples from Dawson Draw (near site DD)

[Analyses by Bureau of Reclamation; concentrations in milligrams per kilogram; $<$, less than]

\begin{tabular}{lcc}
\hline Trace element & Maximum & Minimum \\
\hline Arsenic & 5.6 & 3.6 \\
Lead & 17 & 14 \\
Mercury & .08 & $<.02$ \\
Selenium & 17.1 & .4 \\
Zinc & 86 & 45 \\
\hline
\end{tabular}


The U.S. Geological Survey has collected bottom-sediment data in the Dolores Project area. Seven bottom-sediment samples were collected at Mc Elmo Creek near the Colorado-Utah State line (site ME3 in fig. 1) during 1978-81, and four samples were collected from the San Juan River at Four Corners (site SJ1 in fig. 1) during 1977-79 for trace-element analyses. The range of trace-element concentrations for these samples are summarized in table 5. The U.S. Geological Survey, in cooperation with the Bureau of Reclamation's Dolores River Water Quality study, collected a core sample of bottom sediment from Narraguinnep Reservoir in July 1990 . The purpose of the core sampling was to determine if there were periods when irrigation water, diverted from the Dolores River for storage in Narraguinnep Reservoir, had high concentrations of mercury or other trace elements. Trace-element concentrations in the core sample are listed in table 6. Organochlorine insecticides and PCB's were not detected in two bottom-sediment samples collected in 1979 and 1981 from the San Juan River at Mexican Hat, Utah (site SJ3 in fig. 2).

\section{Biological Data}

The U.S. Fish and Wildlife Service collected biological data in 1988 in the Dolores Project area, and those data are summarized in tables 7 and 8. The U.S. Fish and Wildlife Service also collected biota data in 1989 for a field-screening study of the Mancos River basin, and this information is discussed in the next section.
Table 5. Range of trace-element concentrations in bottomsediment samples collected at Mc Elmo Creek near the Colorado-Utah State line (site ME3) and at San Juan River at Four Comers (site SJ1)

[Analyses by U.S. Geological Survey; concentrations in micrograms per gram; $<$, less than]

\begin{tabular}{lcc}
\hline Trace olement & Mc Elmo Creek & San Juan Rlver \\
\hline Arsenic & $0-5$ & $1-6$ \\
Barium & $40-900$ & $30-50$ \\
Beryllium & $0-10$ & $0-0$ \\
Cadmium & $0-1$ & $0-<1$ \\
Chromium & $2-20$ & $1-10$ \\
Copper & $5-10$ & $0-4$ \\
Lead & $0-20$ & $0-8$ \\
Manganese & $160-560$ & $120-200$ \\
Mercury & $0-.04$ & $0-.01$ \\
Molybdenum & $1-17$ & $0-3$ \\
Nickel & $0-20$ & $0-2$ \\
Selenium & $0-2$ & $0-0$ \\
Zinc & $7-50$ & $10-30$ \\
\hline
\end{tabular}

\section{Mancos River Field-Screening Study}

Fish and wildlife resources in the Mancos Project area for which the DOI has Federal trusteeship include migratory waterfowl and endangered fish. The Mancos River at the confluence with the San Juan River is an important staging area for the endangered Colorado squawfish and the razorback sucker. The roundtail chub and the flannelmouth sucker are candidate species for Federal listing as endangered and are present in the Mancos River along much of its length.

In July 1989, the U.S. Fish and Wildlife Service did a field-screening study of the Mancos River to determine if selenium and other trace elements from irrigation drainage from the Mancos Project were at

Table 6. Concentrations of trace elements in seven sections of a core sample of bottom sediment collected from Narraguinnep Reservoir, July 1990

[Analyses by U.S. Geological Survey; sample interval in centimeters; concentrations in micrograms per gram]

\begin{tabular}{cccccccccc}
\hline $\begin{array}{c}\text { Sample } \\
\text { Interval }\end{array}$ & Arsenic & Barlum & Cadmium & Chromium & Copper & Lead & Mercury & Selenlum & Zinc \\
\hline $0-6$ & 10 & 270 & 1 & 10 & 20 & 30 & 0.05 & 1 & 90 \\
$6-12$ & 10 & 300 & 2 & 20 & 30 & 40 & .05 & 1 & 130 \\
$12-18$ & 10 & 280 & 2 & 10 & 30 & 60 & .05 & 1 & 180 \\
$18-24$ & 11 & 290 & 1 & 10 & 30 & 40 & .04 & 1 & 120 \\
$24-30$ & 7 & 230 & 1 & 9 & 20 & 30 & .05 & 1 & 100 \\
$30-36$ & 10 & 290 & 1 & 10 & 30 & 40 & .05 & 1 & 180 \\
$36-42$ & 9 & 240 & 1 & 10 & 20 & 30 & .03 & 1 & 90 \\
\hline
\end{tabular}


Table 7. Trace-element data for biota samples collected in the Dolores Project area in May and June 1988

[Analyses by U.S. Fish and Wildlife Service; wb., whole body; <, less than; inv., invertebrates; values are range of concentrations, in micrograms per gram dry weight; single value indicates all concentrations were equal to one concentration]

\begin{tabular}{|c|c|c|c|c|c|c|c|}
\hline Location & $\begin{array}{l}\text { Sample } \\
\text { matrix }\end{array}$ & $\begin{array}{l}\text { Number } \\
\text { of } \\
\text { samples }\end{array}$ & Aluminum & Arsonic & Barlum & Beryilium & Boron \\
\hline Dolores River & Fish, wb. & 3 & $75-997$ & $<0.10-0.36$ & $5.6-16.4$ & $<0.05$ & $<3.0$ \\
\hline McPhee Reservoir & Fish, wb. & 3 & 33-130 & $<.10-.49$ & $4.8-9.6$ & $<<.05$ & $<3.0$ \\
\hline $\begin{array}{l}\text { Narraguinnep } \\
\text { Reservoir }\end{array}$ & Fish, wb. & 3 & $29-1,040$ & $<.10-.20$ & $3.4-16.0$ & $<.05$ & $<3.0$ \\
\hline Totten Reservoir & Fish, wb. & 3 & $67-298$ & $<.10-.40$ & $1.7-6.6$ & $<.05$ & $<3.0$ \\
\hline \multirow[t]{5}{*}{ Dawson Draw } & Algae & 4 & $11,800-23,800$ & $3.3-5.5$ & $132-271$ & $.45-.92$ & $5.0-65$ \\
\hline & Aquatic inv. & 5 & $784-7,800$ & $1.3-2.4$ & $59-141$ & $<.05-.32$ & $<3.0$ \\
\hline & Fish, wb. & 7 & $160-710$ & $<.10-.20$ & $6.1-22.6$ & $<.05$ & $<3.0$ \\
\hline & $\begin{array}{l}\text { Canada } \\
\text { goose, liver }\end{array}$ & 3 & $3-5$ & $<.20$ & $<.05-.09$ & $<.05$ & $<3.0$ \\
\hline & Mallard, liver & 3 & 4-8 & $<.20$ & $.10-.38$ & $<.05$ & $<3.0$ \\
\hline Location & Cadmium & $\begin{array}{l}\text { Chro- } \\
\text { mium }\end{array}$ & Copper & Iron & Load & Magnesium & Manganese \\
\hline Dolores River & $0.08-0.40$ & $1.0-6.0$ & $3.6-7.9$ & $101-622$ & $0.10-0.69$ & $933-1,300$ & $24.6-35.2$ \\
\hline McPhee Reservoir & $.04-.07$ & $2.0-5.4$ & $.5-3.0$ & $102-180$ & $<.10$ & $1,180-1,380$ & $9.9-35.4$ \\
\hline $\begin{array}{l}\text { Narraguinnep } \\
\text { Reservoir }\end{array}$ & $.04-.15$ & $1.0-5.2$ & $.9-28.0$ & $79.6-672$ & $<.10-.52$ & $1,140-1,490$ & $3.1-32.3$ \\
\hline Totten Reservoir & $.03-.04$ & $1.0-2.0$ & $1.1-64.6$ & $120-407$ & $<.10-.60$ & $758-1,810$ & $3.1-13.0$ \\
\hline \multirow[t]{5}{*}{ Dawson Draw } & $.15-1.0$ & $10.0-18.0$ & $5.8-16.0$ & $11,300-13,100$ & $3.8-12.0$ & $4,720-6,740$ & $1,050-5,840$ \\
\hline & $.08-.31$ & $3.0-8.0$ & $14.0-95.7$ & $610-5,970$ & $.57-4.5$ & $1,820-2,180$ & $229-1,880$ \\
\hline & $.03-.38$ & $<1.0-4.4$ & $2.1-5.3$ & $160-507$ & $.20-.64$ & $1,060-1,330$ & $23.4-72.4$ \\
\hline & $.05-.08$ & $<1.0-1.0$ & $52.7-65.0$ & $523-1,670$ & $<.10-.20$ & $761-819$ & $11.0-18.0$ \\
\hline & $.41-.95$ & $<1.0$ & $67.0-110$ & $3,070-5,300$ & $.30-.56$ & $699-760$ & $17.0-25.7$ \\
\hline Location & Mercury & $\begin{array}{l}\text { Molyb- } \\
\text { denum }\end{array}$ & Nickel & Selenium & Strontium & Vanadium & Zinc \\
\hline Dolores River & $0.27-0.31$ & $<0.5$ & $2.0-3.0$ & $3.0-6.1$ & $30.2-72.6$ & $<1-1$ & $44-109$ \\
\hline McPhee Reservoir & $.93-1.5$ & $<.5$ & $2.0-3.0$ & $1.5-2.1$ & $29.2-91.9$ & $<1$ & $47-107$ \\
\hline $\begin{array}{l}\text { Narraguinnep } \\
\text { Reservoir }\end{array}$ & $.69-2.6$ & $<.5-2.0$ & $2.0-3.0$ & $1.4-2.1$ & $44.3-97.4$ & $<1-2$ & $41-68$ \\
\hline Totten Reservoir & $.09-.46$ & $<.5-.9$ & $<2.0-2.0$ & $1.4-2.0$ & $32.3-109$ & $<1-1$ & $55-200$ \\
\hline \multirow[t]{5}{*}{ Dawson Draw } & $.02-.05$ & $<1.0-2.0$ & $6.0-14$ & $.57-3.4$ & $90.1-1,010$ & $18-28$ & $46-67$ \\
\hline & $.05-.13$ & $<.5-2.0$ & $2.0-7.5$ & $.93-1.8$ & $45.4-639$ & $1-10$ & $60-96$ \\
\hline & $.18-.50$ & $<.5-.6$ & $2.0-3.0$ & $1.1-4.6$ & $64.2-83.3$ & $<1-1$ & $31-140$ \\
\hline & $.05-.09$ & $.9-1.0$ & $<2.0-2.0$ & $2.9-3.2$ & $.20-.57$ & $<1$ & $155-190$ \\
\hline & $.37-1.7$ & $3.2-7.4$ & $<2.0-2.0$ & $11.0-14.6$ & $.40-.62$ & $<1$ & 109-155 \\
\hline
\end{tabular}


Table 8. Selected trace-element data for fish samples collected in the Dolores Project area in December 1988

[Samples collected by U.S. Fish and Wildlife Service and analyzed by the Bureau of Reclamation; concentrations in micrograms per gram dry weight; <, less than; single value listed for one sample]

\begin{tabular}{|c|c|c|c|c|c|c|}
\hline \multirow{2}{*}{ Location } & \multirow{2}{*}{$\begin{array}{l}\text { Sample } \\
\text { matrix }\end{array}$} & \multirow{2}{*}{$\begin{array}{c}\text { Number of } \\
\text { samples }\end{array}$} & \multicolumn{4}{|c|}{ Range of concentrations } \\
\hline & & & Cadmlum & Lead & Mercury & Selenlum \\
\hline \multirow[t]{2}{*}{ Dolores River } & Fillet & 1 & 0.02 & $<0.07$ & 0.31 & 3.0 \\
\hline & Whole body & 2 & $.19-.37$ & $.10-.20$ & $.16-.26$ & $7.1-8.9$ \\
\hline \multirow[t]{2}{*}{ McPhee Reservoir } & Fillet & 2 & $<.01-.04$ & $.07-.33$ & $1.5-2.7$ & $1.8-2.2$ \\
\hline & Whole body & 3 & $.04-.08$ & $.07-.21$ & $.44-1.5$ & $2.4-2.5$ \\
\hline \multirow[t]{5}{*}{ Narraguinnep Reservoir } & Fillet & 3 & $<.01-.01$ & $<.07<.07$ & $4.8-6.4$ & $2.8-3.0$ \\
\hline & Liver & 1 & .13 & .10 & 2.8 & 6.6 \\
\hline & Kidney & 1 & .67 & .10 & 5.1 & 8.0 \\
\hline & Skin & 1 & .10 & .68 & .89 & 2.1 \\
\hline & Whole body & 1 & $<.01$ & .10 & 1.9 & 2.6 \\
\hline
\end{tabular}

levels of concern in water, bottom sediment, aquatic plants, aquatic invertebrates, fish, and birds. Samples were collected at four sites on the Mancos River (fig. 1): the West Mancos River upstream from the town of Mancos (site PR1); the Mancos River downstream from the town of Mancos (site PR2); the Mancos River near Ute Canyon, south of Mesa Verde National Park (site PR3); and the Mancos River at the Colorado-New Mexico State line (site MN2) (fig. 1).

In 1989, an attempt was made to collect aquatic plants, aquatic invertebrates, and fish at each of the four Mancos River sites. The West Mancos River at site PR1 is a clear stream that has stable, cobble substrate and an abundant assortment of aquatic invertebrates. Rainbow trout, brook trout, and mottled sculpin are the principal fish species in the West Mancos River. The West Mancos River loses water downstream from site PR1 by irrigation diversions. Most of the diversions for the Mancos Project are upstream from the town of Mancos.

At site PR2, the Mancos River was turbid, and sediment covered the bottom of the river. Small aquatic invertebrates were uncommon; crayfish were the most common aquatic invertebrate. Rainbow trout are rarely found in this stream reach, and bluehead suckers, speckled dace, and fathead minnows are the dominant species.

Downstream from Weber Canyon (fig. 1), a tributary of the Mancos River that receives irrigation return flow from the Mancos Project, water in the Mancos River during the summer consists primarily of irrigation return flow and ground water. Severe thunderstorms produce flash floods that regularly flush the canyon. Sampling site PR3 is upstream from Ute Canyon on the Ute Mountain Ute Reservation (fig. 1). The Mancos River in the vicinity of site PR3 is turbid, and the aquatic invertebrate population is limited to crayfish. The only two species of fish found at site PR3 in 1989 were native flannelmouth suckers and roundtail chubs. Roundtail chubs were a significant percentage of the fish population in this reach of the river. Stream discharge in the Mancos River in 1989 was unusually low, and the river had no flow for more than $20 \mathrm{mi}$ from near Ute Canyon downstream to the mouth of the river. During the following 3 years (1990-1992), the river had a year-round flow.

During the field-screening study, samples were collected on the Mancos River at site MN2 (fig. 1), which also was a sampling site for the reconnaissance investigation in 1990. Fish collected at site MN2 in 1989 were in an isolated pool that was about $100 \mathrm{ft}$ long and as much as $5 \mathrm{ft}$ deep. The catfish collected at site MN2 probably were trapped in the pool after moving upstream from the San Juan River. Fish movement in the Mancos River is impeded by a 12-ft-high irrigation diversion structure $1 \mathrm{mi}$ upstream from the Highway 666 bridge (fig. 1).

Water and sediment samples for bioassay analysis were collected from each of the four Mancos River sites and were analyzed by the University of Minnesota Cooperative Fish and Wildlife Research Unit. The bioassay results indicated no chronic or acute toxicity in the analyses done on water fleas (Daphnia magna), fathead minnows (Pimephales promelas), and midge larvae (Chironomus tetans).

Unfiltered, acidified water samples from each of the Mancos River sites were analyzed by Hazelton Laboratories American, Inc., in Madison, Wisconsin. Selenium was detected at sites PR1, PR3, and MN2 at concentrations of $2 \mu \mathrm{g} / \mathrm{L}$ (table 9 ). 


\section{Selenlum concentrations In aquatic blota}

The only trace element of concern in the biota samples collected for the field-screening study was selenium. Selenium concentrations were notably higher in biota from the Mancos River for site MN2 than for sites PR1, PR2, and PR3 (table 9). Lemly and Smith (1987) recommended that $3 \mu \mathrm{g} / \mathrm{g}$ dry weight selenium be used as the toxic threshold in food items that may be consumed by fish and wildlife. Selenium concentrations in aquatic plants collected at the upper sites, PR1 and PR2, were $0.4 \mu \mathrm{g} / \mathrm{g}$ dry weight (table 9) and are less than the suggested dietary guideline of $3 \mu \mathrm{g} / \mathrm{g}$. Aquatic plants were not collected at sites PR3 and MN2 because turbid water conditions inhibited plant growth. Selenium concentrations in aquatic-

Table 9. Trace-element concentrations in water, bottom-sediment, and biota samples collected in the Mancos River basin, July 1,1989

[Analysis by U.S. Fish and Wildlife Service; --, no data; aq., aquatic; inv., invertebrates; fm., flannelmouth; rw., red winged; fish and bird matrices are whole-body samples; length in millimeters; concentrations in micrograms per gram dry weight, except concentrations for water samples, which are in micrograms per liter; $<$, less than]

\begin{tabular}{|c|c|c|c|c|c|c|c|}
\hline Matrix & Species & $\begin{array}{l}\text { Mean } \\
\text { length }\end{array}$ & $\begin{array}{l}\text { Number } \\
\text { in } \\
\text { sampie }\end{array}$ & $\begin{array}{l}\text { Percent } \\
\text { moisture }\end{array}$ & Aluminum & Arsenic & Barium \\
\hline \multicolumn{8}{|c|}{ WEST MANCOS RIVER ABOVE MANCOS (SITE PRI) } \\
\hline Water & -- & -- & -- & -- & 447 & -- & 42 \\
\hline Sediment & Composite & -- & -- & 32.8 & 9,590 & 3.9 & 115 \\
\hline Aq. plant & Algae & -- & -- & 56.8 & 13,100 & 4.5 & 169 \\
\hline Aq. inv. & Composite & -- & 1 & 92.8 & 3,340 & 1.6 & 134 \\
\hline Fish & Rainbow trout & 219 & 1 & 75.1 & 1,010 & .5 & 10.7 \\
\hline Fish & Mottled sculpin & 110 & 7 & 77.3 & 290 & .4 & 15.2 \\
\hline \multicolumn{8}{|c|}{ MANCOS RIVER DOWNSTREAM FROM MANCOS, UPSTREAM FROM WEBER CANYON (SITE PR2) } \\
\hline Water & - & - & -- & -- & 419 & -- & 70 \\
\hline Sediment & Composite & -- & -- & 83.9 & 20,000 & 5.4 & 231 \\
\hline Aq. plant & Sago pondweed & - & -- & 89.9 & 607 & 1.1 & 85.1 \\
\hline Aq. inv. & Crayfish & 120 & 5 & 76.5 & 421 & 1.2 & 73.4 \\
\hline Fish & Rainbow trout & 278 & 1 & 71.4 & $<3$ & .4 & .32 \\
\hline Fish & Bluehead sucker & 196 & 5 & 79.4 & 445 & .4 & 13.8 \\
\hline Fish & Speckled dace & 90 & 35 & 71.5 & 12 & $<.2$ & 6.9 \\
\hline \multicolumn{8}{|c|}{ MANCOS RIVER NEAR UTE CANYON (SITE PR3) } \\
\hline Water & -- & - & -- & -- & 18,200 & - & 140 \\
\hline Sediment & Composite & -- & -- & 41.8 & 10,300 & 4.5 & 164 \\
\hline Aq. inv. & Crayfish & 125 & 6 & 69.3 & 1,040 & 1.3 & 78.4 \\
\hline Fish & Fm. sucker & 360 & 2 & 76.2 & 438 & .3 & 11.9 \\
\hline Fish & Roundtail chub & 380 & 1 & 71.3 & 11 & $<.2$ & 1.5 \\
\hline \multicolumn{8}{|c|}{ MANCOS RIVER NEAR COLORADO-NEW MEXICO STATE LINE (SITE MN2) } \\
\hline Water & -- & -- & -- & -- & 2,940 & -- & 110 \\
\hline Sediment & Composite & -- & -- & 22.2 & 5,280 & 7.7 & 412 \\
\hline Aq. inv. & Crayfish & -- & 17 & 74.5 & 1,710 & 1.7 & 61.9 \\
\hline Fish & Channel catfish & 298 & 2 & 82.8 & 180 & .3 & 6.1 \\
\hline Fish & Fm. sucker & 269 & 5 & 70.9 & 20 & .2 & 3.0 \\
\hline Fish & Speckled dace & 80 & 7 & 64.8 & 57 & $<.2$ & 4.8 \\
\hline \multicolumn{8}{|c|}{ POND IN THE MANCOS VALLEY, WEBER CANYON DRAINAGE (SITE PR4) } \\
\hline Bird & Killdeer & -- & 1 & 71.4 & 523 & $<.2$ & 22.7 \\
\hline Liver & Killdeer & - & 1 & 67.9 & 15 & $<.2$ & .42 \\
\hline Liver & Mallard & -- & 1 & 71.7 & $<3$ & $<.2$ & .40 \\
\hline Liver & Mallard & -- & 1 & 69.7 & $<3$ & $<.2$ & .20 \\
\hline Liver & Ruddy duck & - & 2 & 73.3 & $<3$ & $<.2$ & .10 \\
\hline Liver & Rw. blackbird & - & 1 & 68.7 & $<3$ & $<.2$ & .20 \\
\hline
\end{tabular}


Table 9. Trace-element concentrations in water, bottom-sediment, and biota samples collected in the Mancos River basin, July 1, 1989--Continued

\begin{tabular}{|c|c|c|c|c|c|c|c|c|c|}
\hline Matrlx & Species & $\begin{array}{l}\text { Percent } \\
\text { moisture }\end{array}$ & $\begin{array}{l}\text { Beryl- } \\
\text { lium }\end{array}$ & Boron & Cadmlum & Copper & Iron & Lead & $\begin{array}{l}\text { Magne- } \\
\text { sium }\end{array}$ \\
\hline \multicolumn{10}{|c|}{ WEST MANCOS RIVER ABOVE MANCOS (SITE PR1) } \\
\hline Water & -- & -- & - & 210 & - & $<13$ & 315 & $<15$ & 3.5 \\
\hline Sediment & Composite & 32.8 & 0.43 & 3 & 0.3 & 17.0 & 12,200 & 68 & 1,800 \\
\hline Aq. plant & Algae & 56.8 & .62 & 4 & .3 & 29.9 & 14,300 & 28 & 2,600 \\
\hline Aq. inv. & Composite & 92.8 & $<.1$ & 3 & 2.1 & 60.1 & 5,030 & 35 & 1,930 \\
\hline Fish & Rainbow trout & 75.1 & $<.1$ & 3 & $<.2$ & 10.0 & 895 & $<4$ & 1,060 \\
\hline Fish & Mottled sculpin & 77.3 & $<.1$ & 2 & $<.2$ & 4.1 & 273 & $<4$ & 1,430 \\
\hline \multicolumn{10}{|c|}{ MANCOS RIVER DOWNSTREAM FROM MANCOS, UPSTREAM FROM WEBER CANYON (SITE PR2) } \\
\hline Water & -- & - & -- & 54 & -- & 14 & 505 & $<15$ & 28 \\
\hline Sediment & Composite & 83.9 & .81 & 9.2 & .7 & 149 & 18,500 & 16 & 4,420 \\
\hline Aq. plant & Sago pondweed & 89.9 & $<.1$ & 393 & 5.0 & 19.0 & 836 & 14 & 3,870 \\
\hline Aq. inv. & Crayfish & 76.5 & $<.1$ & 4 & .5 & 219 & 311 & $<4$ & 1,770 \\
\hline Fish & Rainbow trout & 71.4 & $<1$ & 2 & $<.2$ & 3.5 & 42 & $<4$ & 786 \\
\hline Fish & Bluehead sucker & 79.4 & $<.1$ & 3 & .2 & 4.8 & 352 & $<4$ & 1,420 \\
\hline Fish & Speckled dace & 71.5 & $<.1$ & 3 & $<.2$ & 3.0 & 67 & $<4$ & 1,200 \\
\hline \multicolumn{10}{|c|}{ MANCOS RIVER NEAR UTE CANYON (SITE PR3) } \\
\hline Water & -- & - & -- & 154 & - & 24 & 13,100 & 30 & 152 \\
\hline Sediment & Composite & 41.8 & .49 & 6 & $<.2$ & 21.0 & 14,400 & 10 & 7,600 \\
\hline Aq. inv. & Crayfish & 69.3 & $<.1$ & 4 & $<.2$ & 200 & 698 & $<4$ & 4,200 \\
\hline Fish & Fm. sucker & 76.2 & $<.1$ & 3 & $<.3$ & 4.5 & 1,240 & $<5$ & 1,570 \\
\hline Fish & Roundtail chub & 71.3 & $<.1$ & 2 & $<.2$ & 1.8 & 70 & $<4$ & 893 \\
\hline \multicolumn{10}{|c|}{ MANCOS RIVER NEAR COLORADO-NEW MEXICO STATE LINE (SITE MN2) } \\
\hline Water & -. & -- & -- & 376 & -- & $<13$ & 2,920 & $<15$ & 104 \\
\hline Sediment & Composite & 22.2 & .33 & 2 & .3 & 6.4 & 22,600 & 16 & 3,130 \\
\hline Aq. inv. & Crayfish & 74.5 & $<.1$ & 5 & .4 & 104 & 1,200 & $<4$ & 3,420 \\
\hline Fish & Channel catfish & 82.8 & $<.1$ & 2 & $<.2$ & 4.6 & 257 & 4 & -- \\
\hline Fish & Fm. sucker & 70.9 & $<.1$ & 2 & $<.2$ & 5.4 & 62 & $<4$ & 1,020 \\
\hline Fish & Speckled dace & 64.8 & $<.1$ & $<2$ & $<.2$ & 5.4 & 62 & $<4$ & 1,040 \\
\hline \multicolumn{10}{|c|}{$\begin{array}{l}\text { POND IN THE MANCOS VALLEY, WEBER CANYON DRAINAGE (SITE PR4) } \\
\text { PAN }\end{array}$} \\
\hline Bird & Killdeer & 71.4 & $<.1$ & 3 & $<.2$ & 8.3 & 549 & $<4$ & 1,480 \\
\hline Liver & Killdeer & 67.9 & $<.1$ & $<2$ & .7 & 16.0 & 628 & $<4$ & 709 \\
\hline Liver & Mallard & 71.7 & $<.1$ & $<2$ & 2.0 & 14.0 & 4,140 & $<4$ & 477 \\
\hline Liver & Mallard & 69.7 & $<.1$ & $<2$ & 1.4 & 43.1 & 5,000 & $<4$ & 609 \\
\hline Liver & Ruddy duck & 73.3 & $<.1$ & $<2$ & $<.2$ & 29.1 & 411 & $<4$ & 803 \\
\hline Liver & Rw. blackbird & 68.7 & $<.1$ & $<2$ & .5 & 22.0 & 1,140 & $<4$ & 801 \\
\hline
\end{tabular}


Table 9. Trace-element concentrations in water, bottom-sediment, and biota samples collected in the Mancos River basin, July $1,1989--$ Continued

\begin{tabular}{|c|c|c|c|c|c|c|c|c|c|c|}
\hline Matrix & Species & $\begin{array}{c}\text { Percent } \\
\text { moisture }\end{array}$ & $\begin{array}{c}\text { Manga- } \\
\text { nese }\end{array}$ & Mercury & $\begin{array}{l}\text { Molyb- } \\
\text { denum }\end{array}$ & Nickel & $\begin{array}{l}\text { Sele- } \\
\text { nium }\end{array}$ & $\begin{array}{l}\text { Stron- } \\
\text { tium }\end{array}$ & $\begin{array}{l}\text { Vana- } \\
\text { dium }\end{array}$ & Zinc \\
\hline \multicolumn{11}{|c|}{ WEST MANCOS RIVER ABOVE MANCOS (SITE PR1) } \\
\hline Water & _- & -- & 18 & _- & _- & $<20$ & 2 & 198 & -- & 38 \\
\hline Sediment & Composite & 32.8 & 364 & $<0.01$ & -- & 5.8 & .20 & 41.1 & 19 & 61.0 \\
\hline Aq. plant & Algae & 56.8 & 543 & .05 & $<2$ & 14 & .40 & 45.3 & 18 & 69.8 \\
\hline Aq. inv. & Composite & 92.8 & 983 & .06 & $<1$ & 4.6 & 2.0 & 32.7 & 5.8 & 261 \\
\hline Fish & Rainbow trout & 75.1 & 59.0 & .10 & $<1$ & 5.2 & 3.5 & 19.0 & 1.8 & 85.6 \\
\hline Fish & Mottled sculpin & 77.3 & 93.1 & .14 & $<1$ & 2.0 & 4.0 & 92.2 & .8 & 88.4 \\
\hline \multicolumn{11}{|c|}{ MANCOS RIVER DOWNSTREAM FROM MANCOS, UPSTREAM FROM WEBER CANYON (SITE PR2) } \\
\hline Water & -- & -- & 88 & - & - & $<20$ & $<1$ & 768 & -- & 207 \\
\hline Sediment & Composite & 83.9 & 469 & .02 & $<2$ & 18 & 1.3 & 155 & 29 & 109 \\
\hline Aq. plant & Sago pondweed & 89.9 & 1,590 & .65 & 5 & 4.4 & .40 & 272 & 1.0 & 52.0 \\
\hline Aq. inv. & Crayfish & 76.5 & 137 & .07 & $<1$ & 2.0 & .89 & 462 & .7 & 70.7 \\
\hline Fish & Rainbow trout & 71.4 & 1.5 & .12 & $<1$ & $<1$ & 2.5 & 4.2 & $<.3$ & 52.9 \\
\hline Fish & Bluehead sucker & 79.4 & 51.6 & .06 & $<1$ & 2 & 1.5 & 73.5 & .7 & 84.4 \\
\hline Fish & Speckled dace & 71.5 & 16.0 & .19 & $<1$ & $<1$ & 5.1 & 80.5 & $<.3$ & 148 \\
\hline \multicolumn{11}{|c|}{ MANCOS RIVER NEAR UTE CANYON (SITE PR3) } \\
\hline Water & -- & -- & 202 & -- & - & 22 & 2 & 2,940 & -- & 60 \\
\hline Sediment & Composite & 41.8 & 365 & .02 & - & 12 & .91 & 148 & 21 & 50.6 \\
\hline Aq. inv. & Crayfish & 69.3 & 145 & .09 & $<1$ & 2 & 2.2 & 777 & 1.8 & 63.0 \\
\hline Fish & Fm. sucker & 76.2 & 64.9 & .38 & $<1$ & 5.6 & 3.8 & 84.0 & 1.1 & 84.2 \\
\hline Fish & Roundtail chub & 71.3 & 2.7 & 1.3 & $<1$ & $<1$ & 4.4 & 32.4 & $<.3$ & 56.0 \\
\hline \multicolumn{11}{|c|}{ MANCOS RIVER NEAR COLORADO-NEW MEXICO STATE LINE (SITE MN2) } \\
\hline Water & -- & -- & 152 & -- & -- & $<20$ & 2 & 2,120 & -- & 81 \\
\hline Sediment & Composite & 22.2 & 275 & $<.01$ & $<3$ & 7.7 & .81 & 128 & 18 & 43.8 \\
\hline Aq. inv. & Crayfish & 74.5 & 94.7 & .11 & $<1$ & 4 & 9.9 & 710 & 3.9 & 62.3 \\
\hline Fish & Channel catfish & 82.8 & 12.0 & .66 & $<1$ & $<1$ & 5.7 & 104 & .5 & 96.3 \\
\hline Fish & Fm. sucker & 70.9 & 9.6 & .12 & $<1$ & $<1$ & 7.0 & 65.4 & $<.3$ & 49.6 \\
\hline Fish & Speckled dace & 64.8 & 8.6 & .18 & $<1$ & $<1$ & 11.0 & 119 & $<.3$ & 117 \\
\hline \multicolumn{11}{|c|}{ POND IN THE MANCOS VALLEY, WEBER CANYON DRAINAGE (SITE PR4) } \\
\hline Bird & Killdeer & 71.4 & 11 & .06 & $<1$ & $<2$ & 20.9 & 57.0 & 1.2 & 95.9 \\
\hline Liver & Killdeer & 67.9 & 14 & .13 & 3 & $<2$ & 25.7 & .68 & $<.3$ & 80.9 \\
\hline Liver & Mallard & 71.7 & 7.1 & .22 & 5 & $<2$ & 33.3 & .3 & $<.3$ & 103 \\
\hline Liver & Mallard & 69.7 & 9.2 & .15 & 4 & $<2$ & 25.3 & .2 & $<.3$ & 157 \\
\hline Liver & Ruddy duck & 73.3 & 12 & .01 & 2 & $<2$ & 69.0 & .69 & $<.3$ & 11.3 \\
\hline Liver & Rw. blackbird & 68.7 & 4.8 & .23 & 4 & $<2$ & 10.0 & .1 & $<.3$ & 82.9 \\
\hline
\end{tabular}


invertebrate samples ranged from $0.89 \mu \mathrm{g} / \mathrm{g}$ dry weight at site PR2 to $9.9 \mu \mathrm{g} / \mathrm{g}$ dry weight in a crayfish sample collected at site MN2 (table 9). The concentration of $9.9 \mu \mathrm{g} / \mathrm{g}$ dry weight is more than 3 times higher than the dietary guideline of $3 \mu \mathrm{g} / \mathrm{g}$ suggested by Lemly and Smith (1987).

Fish species collected for the field-screening study varied by site because of major changes in stream habitat through the sampled reach of the Mancos River. Therefore, comparisons of selenium in similar species between sites could not be made. Generally, the selenium concentrations in fish collected in the lower reach of the Mancos River (sites PR3 and MN2) were higher than in fish from the upper reaches at sites PR1 and PR2. Selenium concentrations in nine of the ten wholebody fish samples collected from the Mancos River exceeded the National Contaminant Biomonitoring Program (NCBP) 85th percentile of $0.73 \mu \mathrm{g} / \mathrm{g}$ wet weight (Schmitt and Brumbaugh, 1990) for selenium. The selenium concentrations in six fish samples equaled or exceeded the selenium concentration of $4 \mu \mathrm{g} / \mathrm{g}$ dry weight that Lemly (1993) recommended as being the level of concern for overall health and reproductive vigor of freshwater fish. The highest selenium concentration in fish at each site was in the smallest species, speckled dace or mottled sculpin. These smaller fish often are consumed by higher trophic species.

\section{Selenium concentrations In birds}

Birds were collected from a small farm pond and wetland area in the lower part of the Mancos Project at site PR4 (fig. 1). This pond and wetland complex received irrigation supply water from laterals and irrigation return flow from an adjoining field. However, the supply water in the lower part of the project is return flow from upstream irrigated areas. Ponds and wetlands are not common in the Mancos River basin; however, the ponds and wetlands that are present attract a large number of waterfowl and shorebirds. About 20 young-of-year American coots and several young mallards were observed at site PR4. The presence of the young birds indicates that waterfowl are reproducing at sites that have available nesting habitat.

As with fish samples, selenium was the element of concern in bird samples. Concentrations of selenium in bird-tissue samples ranged from $10 \mu \mathrm{g} / \mathrm{g}$ dry weight in a red-winged blackbird liver to $69 \mu \mathrm{g} / \mathrm{g}$ dry weight in a composite sample of two sub-adult ruddy duck livers (table 9). J.P. Skorupa (U.S. Fish and Wildlife Service, written commun., 1993) reported that baseline mean selenium concentrations rarely exceed
$10 \mu \mathrm{g} / \mathrm{g}$ dry weight in bird livers. All bird-liver samples collected at site PR4 (table 9) had selenium concentrations that equaled or exceeded $10 \mu \mathrm{g} / \mathrm{g}$ dry weight. All birds collected at site PR4 were immature or were adults that were brooding young, which indicates that the selenium in these birds was obtained at this site.

J.P. Skorupa (U.S. Fish and Wildlife Service, written commun., 1993) reported a high risk of adverse biological effects when mean selenium concentrations of a population exceeds $30 \mu \mathrm{g} / \mathrm{g}$ dry weight in bird livers. J.P. Skorupa also suggested that where mean selenium concentrations are between 10 and $30 \mu \mathrm{g} / \mathrm{g}$ dry weight in livers, additional studies of reproductive performance are needed for conclusive interpretation of biological significance. Selenium concentrations in all bird samples collected at site PR4 equaled or exceeded those concentrations of concern. The selenium concentrations in birds from site PR4 indicate that there is a source of selenium available at this site and that bioaccumulation of selenium in birds was occurring. The concentration of selenium in birds represents a level of concern, and additional studies in the upper Mancos River basin would be required to determine whether selenium is causing deformities or affecting reproductive rates.

\section{SAMPLE COLLECTION AND ANALYSIS}

\section{Objectives}

One objective of surface-water and bottomsediment sampling for the reconnaissance investigation was to determine concentrations of trace elements and pesticides in water and bottom sediment in streams draining long-term irrigated areas in the MVIC area. Another objective was to collect water and bottomsediment data in newly irrigated areas in the Dove Creek area, and a third objective was to collect data for the Mancos and San Juan Rivers upstream from and downstream from the Dolores Project. Problem areas were to be identified where trace-element concentrations in water exceeded drinking-water regulations, criteria for protection of aquatic life, or criteria for agricultural use. Water and bottom-sediment data collected in irrigated areas were compared to data collected at reference sites to determine if irrigation drainage was contributing potentially harmful constituents to streams and reservoirs. Trace-element concentrations in bottom sediment were compared to trace-element concentrations in soils in the Western United States.

A standard set of chemical constituents was analyzed in water and bottom-sediment samples collected 
for the reconnaissance investigation. The list of constituents was developed by the DOI Task Group for use in all irrigation drainage studies to enable comparison of data among the reconnaissance investigations. The constituents for analysis in each medium are listed in table 10. Pesticide compounds selected for analysis in water and bottom sediment (table 10) were based on past or present usage in the Dolores Project area.
A primary objective of the biological sampling was to determine if trace-element concentrations in biota were of concern and to identify the potential for contaminant bioaccumulation within different trophic levels. Biota selected from lower trophic levels (aquatic plants and aquatic invertebrates) represented possible food sources for either fish or migratory birds that were most likely to be present in the Dolores

Table 10. Constituents analyzed in water, bottom-sediment, and biota samples

[All constituents reported as total, except inorganic constituents in water, which were reported as dissolved; $\mathbf{N}$, nitrogen]

\begin{tabular}{|c|c|c|c|c|c|}
\hline \multicolumn{2}{|c|}{ Water } & \multicolumn{2}{|c|}{ Bottom sediment } & \multicolumn{2}{|c|}{ Biota } \\
\hline Inorganic & Pesticides & Inorganic & Pesticides & Inorganic & Pesticides \\
\hline Hardness & 2,4-D & Arsenic & $\mathrm{PCN}$ & Aluminum & alpha-BHC \\
\hline Calcium & 2,4-DP & Barium & PCB & Arsenic & beta-BHC \\
\hline Magnesium & Silvex & Beryllium & Aldrin & Barium & gamma-BHC \\
\hline Sodium & $2,4,5-\mathrm{T}$ & Bismuth & Chlordane & Beryllium & alpha-Chlordane \\
\hline Potassium & Dicamba & Cadmium & DDD & Boron & gamma-Chlordane \\
\hline Sulfate & Picloram & Cerium & DDE & Cadmium & o,p'-DDE \\
\hline Chloride & DEF & Chromium & DDT & Chromium & p,p'-DDE \\
\hline Alkalinity & Diazinon & Cobalt & Dieldrin & Copper & o,p'-DDD \\
\hline Fluoride & Disyston & Copper & Endosulfan & Iron & p,p'-DDD \\
\hline Dissolved solids & Ethion & Europium & Endrin & Lead & o,p'-DDT \\
\hline Nitrite & Malathion & Gallium & Heptachlor & Magnesium & p,p'-DDT \\
\hline \multirow[t]{2}{*}{ Nitrite plus nitrate as $\mathrm{N}$} & Methyl parathion & Gold & Heptachlor epoxide & Manganese & Dieldrin \\
\hline & Methyl trithion & Holmium & Lindane & Mercury & Endrin \\
\hline Ammonia & Parathion & Lanthanum & Mirex & Nickel & $\mathrm{HCB}$ \\
\hline Orthophosphorus & Phorate & Lead & Perthane & Selenium & Heptachlor epoxide \\
\hline Arsenic & Trithion & Lithium & Toxaphene & Strontium & Mirex \\
\hline Boron & & Manganese & & Vanadium & cis-Nonachlor \\
\hline Cadmium & & Mercury & & Zinc & trans-Nonachlor \\
\hline Chromium & & Molybdenum & & & Oxychlordane \\
\hline Copper & & Neodymium & & & Toxaphene \\
\hline Lead & & Nickel & & & PCB \\
\hline Mercury & & Niobium & & & \\
\hline Molybdenum & & Scandium & & & \\
\hline Selenium & & Selenium & & & \\
\hline Vanadium & & Silver & & & . \\
\hline Zinc & & Strontium & & & \\
\hline \multirow[t]{8}{*}{ Uranium, total } & & Tantalum & & & \\
\hline & & Thorium & & & \\
\hline & & Tin & & & \\
\hline & & Uranium & & & \\
\hline & & Vanadium & & & \\
\hline & & Ytterbium & & & \\
\hline & & Yttrium & & & \\
\hline & & Zinc & & & \\
\hline
\end{tabular}


Project area. Consistency in species composition of samples among sites was attempted so that direct comparisons of data could be made between sites and areas. Consistency among species could not always be achieved because of habitat variability and because of insufficient numbers of organisms to obtain an adequate biomass for analysis.

\section{Sampling Sites and Schedule of Sample Collection}

Water-quality samples for inorganic analysis were collected at 19 stream sites, 2 sites representing irrigation water from McPhee Reservoir, 3 reservoirs, and 4 ground-water sites for the reconnaissance investigation of the Dolores Project area during 1990 (table 11). All sampling sites are shown in figures 1 and 2. Streams were sampled three times (table 12) during 1990 to document seasonal differences in water chemistry and in trace-element concentrations. Water samples for inorganic analyses were collected from reservoirs only in the pre-irrigation (April) and postirrigation (November) seasons.

Four sites on Mc Elmo Creek were sampled for the reconnaissance investigation (table 11). Site ME1 is upstream from MVIC irrigated areas and is a reference site relative to the MVIC area. Site ME2 is downstream from most of the irrigated land within the MVIC area. Site ME3 was sampled to determine effects from irrigation along Mc Elmo Creek downstream from Cortez (non project irrigation). Site ME4 is the outflow site for Mc Elmo Creek and is downstream from all irrigated areas. Major pathways of irrigation drainage and return flow from the MVIC area are represented by the sampling sites on tributaries of Mc Elmo Creek. The sampling sites are Hartman Draw (sites HD1 and HD2), Alkali Wash (site AK), Dawson Draw (site DD), and the lower site on Yellow Jacket Canyon (site YJ2). Navajo Wash (site NW), tributary to the Mancos River, is a pathway for irrigation drainage from the extreme southern part of the MVIC area. Water samples also were collected from Totten Reservoir (site TT), which is located in the MVIC area. Summit Reservoir (site SU), Puett Reservoir (site PU), and Simon Draw (site SD) are reference sites for the MVIC area. Water quality of all irrigation source water from McPhee Reservoir into the MVIC area and to the newly irrigated areas was sampled at the outlets of the Dolores Tunnel (site DT) and the Great Cut Dike (site GD).

Selection of sampling sites in newly irrigated areas or areas yet to be irrigated was restricted because the many small arroyos and washes draining those areas did not have flow. The upper site on Yellow
Jacket Canyon (site YJ1) and the sites on Woods Canyon (site WC) and Cahone Canyon (site $\mathrm{CH}$ ) are downstream from newly irrigated areas that were being irrigated during 1990. Water samples collected at those sites were from irrigation drainage from land that has been irrigated less than 3 years. The site on Cross Canyon (site CR) is a reference site (upstream from irrigated land) for the Dove Creek area because irrigation had not begun in 1990 in the basin upstream from site CR. The three observation wells (sites OW1, OW2, and OW3) are located in newly irrigated areas, and water samples from those wells probably were from shallow irrigation drainage that had collected in low areas. There was no flow in streams and washes draining land to be irrigated on the Ute Mountain Ute Reservation other than in the Mancos River (sites MN1 and MN2).

Two sites were selected on the San Juan River for water sampling. Site SJ1 (fig. 1) is downstream from the Mancos River and upstream from Mc Elmo Creek. Site SJ3 (fig. 2) is downstream from the Dolores Project and is the outflow from the San Juan River into Lake Powell (fig. 2). The San Juan River upstream from the Mancos River was sampled for the reconnaissance investigation of the San Juan basin in northern New Mexico. Site GW at Aneth, Utah (fig. 2) is a seep area along the San Juan River Valley. Samples from site $\mathrm{GW}$ are from ground water discharging from bedrock through an abandoned gas well. Water from the seep area discharges into the San Juan River.

Water samples for pesticide analysis were collected at 12 stream sites and 2 reservoir sites (table 11) in July 1990 (table 12). The pesticide samples were collected in summer during or after the time when pesticides normally are applied in the Dolores Project area.

Bottom-sediment samples for inorganic and chlorinated pesticide analyses were collected at 18 sites (table 11). The samples were collected in November 1990 (table 12), when maximum accumulation of potential contaminants from irrigation drainage was expected.

Biota sampling sites were selected to determine maximum contaminant concentrations associated with irrigation drainage. Biota sampling sites were selected relative to inflow and outflow of irrigation drainage and based on the availability of biota. Biota samples generally were collected from streams at or near the waterquality sampling sites (table 11). Stream sites were scheduled to be sampled for aquatic plants, aquatic invertebrates, and fish during April, July, and November (table 12). Fish samples also were collected from the San Juan River at Bluff (site SJ2) in July 1990, and from McPhee Reservoir (site MP). 
Table 11. Sampling sites and type of samples collected for the reconnaissance investigation during 1990

[MVIC, Montezuma Valley Irrigation Company; X, sampled for the reconnaissance investigation; --, not sampled]

\begin{tabular}{|c|c|c|c|c|c|c|c|}
\hline & & \multicolumn{2}{|c|}{ Water } & \multicolumn{2}{|c|}{ Bottom Sodiment } & \multicolumn{2}{|c|}{ Biota } \\
\hline $\begin{array}{c}\text { number } \\
\text { (figs. } \\
\mathbf{1 , 2 )}\end{array}$ & Site name & Inorganic & Pesticidos & Inorganic & Pestlcides & Inorganle & Pestlcldes \\
\hline \multicolumn{8}{|c|}{ MVIC AREA } \\
\hline ME1 & $\begin{array}{l}\text { Mc Elmo Creek at Highway } 160, \\
\text { near Cortez }\end{array}$ & $\mathbf{X}$ & -- & - & - & $\mathbf{X}$ & - \\
\hline ME2 & $\begin{array}{l}\text { Mc Elmo Creek downstream from } \\
\text { Alkali Canyon }\end{array}$ & $\mathbf{x}$ & $\mathbf{x}$ & $\mathbf{x}$ & $\mathbf{x}$ & $\mathbf{x}$ & $\mathbf{X}$ \\
\hline ME3 & $\begin{array}{l}\text { Mc Elmo Creek upstream from } \\
\text { Yellow Jacket Canyon }\end{array}$ & $\mathbf{x}$ & -- & $\mathbf{X}$ & $\mathbf{X}$ & $\mathbf{x}$ & - \\
\hline ME4 & $\begin{array}{l}\text { Mc Elmo Creek downstream from } \\
\text { Yellow Jacket Canyon }\end{array}$ & $\mathbf{x}$ & $\mathbf{x}$ & $\mathbf{x}$ & $\mathbf{x}$ & $\mathbf{x}$ & $\mathbf{x}$ \\
\hline DT & Dolores Tunnel outflow & $\mathbf{x}$ & -- & -- & -- & -- & - \\
\hline GD & Great Cut Dike outflow & $\mathbf{X}$ & -- & -- & -- & -- & -- \\
\hline MP & McPhee Reservoir & -- & -- & -- & .- & $\mathbf{x}$ & -- \\
\hline SU & Summit Reservoir & $\mathbf{x}$ & $\mathbf{X}$ & $\mathbf{x}$ & $\mathbf{X}$ & $\mathbf{X}$ & -- \\
\hline PU & Puett Reservoir & $\mathbf{X}$ & -- & $\mathbf{X}$ & $\mathbf{X}$ & $\mathbf{X}$ & -- \\
\hline TT & Totten Reservoir & $\mathbf{X}$ & $\mathbf{X}$ & $\mathbf{x}$ & $\mathbf{x}$ & $\mathbf{X}$ & $\mathbf{X}$ \\
\hline LP & Leighton Pond & -- & - & - & -- & $\mathbf{X}$ & $\mathbf{x}$ \\
\hline SD & $\begin{array}{l}\text { Simon Draw downstream from } \\
\text { Cash Canyon }\end{array}$ & $\mathbf{x}$ & $\mathbf{X}$ & $\mathbf{X}$ & $\mathbf{x}$ & $\mathbf{x}$ & -- \\
\hline HD1 & Hartman Draw near Lebanon & $\mathbf{x}$ & -- & -- & -- & $\mathbf{x}$ & -- \\
\hline HD2 & Hartman Draw near mouth, at Cortez & $\mathbf{x}$ & $\mathbf{X}$ & $\mathbf{X}$ & $\mathbf{x}$ & $\mathbf{X}$ & $\mathbf{X}$ \\
\hline $\mathrm{AK}$ & $\begin{array}{l}\text { Alkali Canyon downstream from } \\
\text { Narraguinnep Canyon }\end{array}$ & $\mathbf{X}$ & $\mathbf{X}$ & $\mathbf{X}$ & $\mathbf{x}$ & $\mathbf{X}$ & $\mathbf{X}$ \\
\hline DD & Dawson Draw near Lewis & $\mathbf{x}$ & $\mathbf{X}$ & $\mathbf{X}$ & $\mathbf{X}$ & $\mathbf{X}$ & $\mathbf{X}$ \\
\hline YJ2 & Yellow Jacket Canyon at mouth & $\mathbf{X}$ & $\mathbf{x}$ & $\mathbf{X}$ & $\mathbf{X}$ & $\mathbf{x}$ & -- \\
\hline NW & Navajo Wash near Towaoc & $\mathbf{X}$ & $\mathbf{X}$ & $\mathbf{X}$ & $\mathbf{X}$ & $\mathbf{x}$ & -- \\
\hline \multicolumn{8}{|c|}{ DOVE CREEK AREA } \\
\hline YJ1 & $\begin{array}{l}\text { Tributary of Yellow Jacket Canyon at } \\
\text { Highway } 666\end{array}$ & $\mathbf{x}$ & -- & -- & - & $\mathbf{X}$ & -- \\
\hline WC & Woods Canyon near Yellow Jacket & $\mathbf{X}$ & -- & $\mathbf{X}$ & $\mathbf{X}$ & $\mathbf{X}$ & -- \\
\hline $\mathrm{CH}$ & Cahone Canyon at Highway 666 & $\mathbf{X}$ & $\mathbf{X}$ & $\mathbf{X}$ & $\mathbf{X}$ & $\mathbf{X}$ & -- \\
\hline CR & $\begin{array}{l}\text { Cross Canyon upstream from } \\
\text { Alkali Canyon }\end{array}$ & $\mathbf{X}$ & -- & $\mathbf{X}$ & $\mathbf{X}$ & $\mathbf{X}$ & - \\
\hline $\mathrm{AKP}$ & $\begin{array}{l}\text { Pond in Alkali Canyon, in } \\
\text { Cross Canyon basin }\end{array}$ & -- & -- & -- & -- & $\mathbf{x}$ & $\mathbf{x}$ \\
\hline ow1 & $\begin{array}{l}\text { Observation well } 7.5 \text { miles west of } \\
\text { Pleasant View }\end{array}$ & $\mathbf{x}$ & -- & -- & -- & -- & -- \\
\hline ow2 & $\begin{array}{l}\text { Observation well } 2.5 \text { miles southeast } \\
\text { of Cahone }\end{array}$ & $\mathbf{x}$ & -- & -- & -- & -- & -- \\
\hline ow3 & $\begin{array}{l}\text { Observation well } 3.2 \text { miles west of } \\
\text { Yellow Jacket }\end{array}$ & $\mathbf{x}$ & -- & - & -- & - & -- \\
\hline \multicolumn{8}{|c|}{ MANCOS AND SAN JUAN RIVERS } \\
\hline MN1 & Mancos River at Highway 666 & $\mathbf{x}$ & -- & -- & -- & $\mathbf{x}$ & .- \\
\hline MN2 & $\begin{array}{l}\text { Mancos River at Colorado-New } \\
\text { Mexico State line }\end{array}$ & $\mathbf{x}$ & $\mathbf{x}$ & $\mathbf{x}$ & $\mathbf{x}$ & $\mathbf{X}$ & $\mathbf{X}$ \\
\hline SJ1 & San Juan River at Four Corners & $\mathbf{X}$ & $\mathbf{x}$ & $\mathbf{X}$ & $\mathbf{X}$ & $\mathbf{X}$ & -- \\
\hline SJ2 & San Juan River near Bluff, Utah & -- & .- & - & - & $\mathbf{X}$ & -- \\
\hline SJ3 & San Juan River at Mexican Hat, Utah & $\mathbf{x}$ & $\mathbf{x}$ & $\mathbf{X}$ & $\mathbf{x}$ & $\mathbf{X}$ & -. \\
\hline GW & $\begin{array}{l}\text { Seep area along San Juan River at } \\
\text { Aneth, Utah }\end{array}$ & $\mathbf{X}$ & -- & - & -- & -- & -- \\
\hline
\end{tabular}


Table 12. Collection schedule of water, bottom-sediment, and biota samples for the reconnaissance investigation during 1990

\begin{tabular}{|c|c|}
\hline $\begin{array}{c}\text { Sample medium and type of } \\
\text { analysis }\end{array}$ & $\begin{array}{l}\text { Months in which } \\
\text { samples were } \\
\text { collected }\end{array}$ \\
\hline Streams, inorganic & $\begin{array}{l}\text { March, April, July, } \\
\text { November }\end{array}$ \\
\hline Reservoirs, inorganic & April, November \\
\hline Streams and reservoirs, pesticides & July \\
\hline McPhee Reservoir outflow, inorganic & May, August \\
\hline Bottom sediment, inorganic & November \\
\hline Bottom sediment, pesticides & November \\
\hline Fish, streams, inorganic & April, July, November \\
\hline Fish, reservoirs, inorganic & $\begin{array}{l}\text { April, May, June, } \\
\text { November }\end{array}$ \\
\hline Fish, pesticides & June, July \\
\hline Aquatic plants, inorganic & April, July, November \\
\hline Aquatic invertebrates, inorganic & April, July, November \\
\hline Birds, inorganic & May, July \\
\hline Birds, pesticides & May, July \\
\hline Eggs, inorganic & May, July \\
\hline Eggs, pesticides & May, July \\
\hline
\end{tabular}

Aquatic plants collected were algae, coontail, sago pondweed, horned pondweed, and watercress. Aquatic-invertebrate species collected were crayfish, snails, aquatic insects, and zooplankton. Fish species collected included: rainbow trout, kokanee salmon, northern pike, channel catfish, walleye, largemouth bass, smallmouth bass, yellow perch, black crappie, green sunfish, flannelmouth suckers, white suckers, bluehead suckers, common carp, roundtail chubs, bluegill, speckled dace, red shiners, and fathead minnows.

Bird samples were collected at Totten Reservoir (site TT), Leighton Pond (site LP), Dawson Draw (site DD), a pond in Woods Canyon (site WC), and a pond in Alkali Canyon (site AKP, in the Cross Canyon drainage basin). Birds and eggs were collected during May and July in 1990 (table 12). Bird species collected during the reconnaissance investigation were: mallard, red-winged blackbird, yellow-headed blackbird, American coot, sora rail, and pied-billed grebe. The sampling period was selected based on availability of pre-fledgling birds and bird eggs. Because prefledglings generally are confined to a given locale until they fledge, trace elements and pesticides in their tissue may be obtained from food and water in the area where the birds are reared, although females can pass some trace elements and organochlorine pesticides to eggs.
An attempt was made to collect pre-fledglings immediately before fledging because older birds would be exposed to contaminants present in the area for a longer period than younger birds. These bird collections were not always possible because of time limitations in the sampling effort and because of considerable predatory activity on young birds. Although developmental abnormalities among embryos in bird eggs cannot be detected before the egg has reached one-half term (Ohlendorf and others, 1986), eggs were collected as soon as they were discovered because of the high risk of predatory loss of eggs in the Dolores Project area. Therefore, early collection to ensure that representative egg samples were available for contaminant analysis outweighed the loss of pathological information related to developmental abnormalities.

\section{Sampling Methods}

At stream sites, stream discharge, specific conductance, $\mathrm{pH}$, water temperature, and dissolved oxygen were measured. Instantaneous stream discharge was determined at sites that had streamflow-gaging stations from the stage record and from stage-discharge rating tables; otherwise, stream discharge was measured using standard techniques of the U.S. Geological Survey (Rantz and others, 1982).

Water-quality samples were collected at stream sites using depth-integrating samplers and methods described by Ward and Harr (1990). Where stream depths were too shallow to use samplers, representative water samples were collected from the centroid of flow or from several verticals across the stream using sample-collection bottles. Water samples for pesticides were collected from the centroid of flow when possible, using sample bottles furnished by the National Water Quality Laboratory of the U.S. Geological Survey. Water samples from reservoirs were collected using a Van Dorn sampler. Ground-water samples were collected using a bailer.

The availability of fine bottom sediment at many stream sites was limited to pools or backwater areas. Bottom-sediment samples were collected from areas of deposition using a BMH-53 sampler (Edwards and Glysson, 1988), and were composited in a stainlesssteel bucket using a stainless-steel spoon. Bottom sediment in reservoirs was collected using an Ekman grab sampler (Britton and Greeson, 1988). Bottomsediment samples were composited in the bucket, and subsamples were taken for inorganic and pesticide analyses.

Quality-assurance samples were collected for water and bottom-sediment sampling. Water samples 
analyzed for quality assurance (all collected in the field) included six deionized water blanks, three sequential duplicate samples, and three split samples. The quality-assurance water samples were analyzed for the inorganic constituents in water listed in table 10. Bottom-sediment samples analyzed for quality assurance included one duplicate sample, one split sample, and a soil sample used as an internal standard by the laboratory. The bottom-sediment samples were analyzed for the inorganic constituents listed in table 10 .

Biological samples were collected by the U.S. Fish and Wildlife Service using standard equipment and techniques (U.S. Fish and Wildlife Service, 1986, 1990). Fish were collected using electroshocking equipment and seine or gill nets. Fish were rinsed, weighed, measured for length, and immediately frozen on dry ice until stored in a freezer. Whole-body samples were composited by species into groups of three or more fish as directed by the DOI sampling protocol. Fillet and egg samples were taken from individual fish and were not composited. Fish for analysis of inorganic contaminants were frozen in plastic bags. Fish samples for analysis of organic compounds were wrapped in aluminum foil and placed in plastic bags.

Vascular plants and algae were collected by handpicking. These samples were placed in chemically cleansed jars, weighed, and frozen. Algae samples probably contained green algae (Chlorophyta) and blue-green algae (Cyanophyta), and plankton samples consisted of phytoplankton and zooplankton. Stream invertebrates were collected using a kick screen, and lake plankton samples were collected using a plankton tow. Several easily identifiable invertebrate groups were combined to obtain sufficient biomass for analysis. Crayfish were collected when present.

Birds were shot using steel shot, and livers were removed using stainless-steel dissecting equipment. Based on the literature (Ohlendorf, 1993), bird liver was determined to be the best organ for a general traceelement scan, although other organs may be better indicators for specific elements (such as kidney for cadmium and bone for lead). Dissecting equipment was cleansed with water and soap and rinsed with distilled water and benzene prior to removal of each liver. Bird livers and muscle tissue were placed in chemically cleansed jars, weighed, and frozen. Livers from each bird group were sometimes composited, which resulted in two or three livers constituting one sample.

After locating nests, bird eggs were removed, the egg volume was determined (by water displacement), and eggs were opened to examine embryos for developmental abnormalities. After examination, eggs were placed in chemically cleansed jars, weighed, and frozen. Small eggs were composited to provide sufficient biomass for analysis.

\section{Analytical Support}

Analyses of water samples for major constituents and trace elements, except uranium, were done by the U.S. Geological Survey National Water Quality Laboratory in Arvada, Colorado. Analytical methods are described in Fishman and Friedman (1989) and laboratory quality-assurance methods are described in Jones (1987). Analysis for uranium was done using a method described in Thatcher and others (1977) by a private laboratory contracted by the U.S. Geological Survey. Analysis for pesticides in water and bottom-sediment samples (table 10) was done by the National Water Quality Laboratory, using methods described by Wershaw and others (1987).

Bottom-sediment samples were analyzed for trace elements by the U.S. Geological Survey Branch of Exploration Geochemistry Laboratory in Lakewood, Colorado. The samples were dry sieved at the laboratory through a $2-\mathrm{mm}$ screen. The samples then were split, and one split was sieved through a $0.0625-\mathrm{mm}$ screen. Both size fractions, less than $2 \mathrm{~mm}$ and less than $0.0625 \mathrm{~mm}$, were analyzed for trace elements. Analytical methods for bottom-sediment analyses are described by Severson and others (1991).

Biological samples were analyzed by Hazelton Laboratories America, Inc., in Madison, Wisconsin, and by the Environmental Trace Substances Research Center in Columbia, Missouri. These laboratories were contracted by the U.S. Fish and Wildlife Service Patuxent Analytical Control Facility in Laurel, Maryland. Biological samples were analyzed for the constituents listed in table 10. Analyses for most trace elements in biota samples were done using inductively coupled argon-plasma atomic-absorption spectrometry after complete digestion of the sample by strong acids. Analysis for arsenic and selenium in biota samples was done using hydride-generation atomic-absorption spectrometry, and analysis for mercury was done using flameless cold-vapor atomic-absorption spectrometry. Analysis for pesticide residues in biota samples consisted of solvent extraction and electron-capture gas chromatography.

\section{DISCUSSION OF RESULTS}

\section{Water Quality}

Inorganic data collected for the reconnaissance investigation of the Dolores Project area are listed in table 22. Pesticide data for water samples are listed in table 23. Tables 22 and 23 are in the "Supplemental Data" section at the back of the report. 


\section{Guldelines for Interpretation of Water-Quality Data}

Water-quality data collected in the Dolores Project area during 1990 were compared to U.S. Environmental Protection Agency drinking-water regulations (U.S. Environmental Protection Agency, 1988a,b, 1991) and aquatic-life criteria (U.S. Environmental Protection Agency, 1986, 1987). Water-quality data also were compared to Colorado agricultural-use criteria (Colorado Department of Health, 1989). The comparisons were used to determine if constituent concentrations in water samples may adversely affect the suitability of water for domestic use, have adverse effects on aquatic life, or affect the suitability of the water for agricultural use. Drinking-water regulations (table 13) that are a maximum contaminant level
(MCL) are legally enforceable; regulations that are a secondary maximum contaminant level (SMCL) are advisory recommendations and are not legally enforceable.

Aquatic-life criteria (table 13) of the U.S. Environmental Protection Agency were established to protect aquatic organisms from chronic or acute effects from exposure to potentially toxic trace elements. Chronic criteria are for protection of aquatic organisms from adverse effects, such as reproductive problems or decreased growth caused by long-term exposure to the trace element. Acute criteria are for protection of aquatic organisms from lethal effects and are based on toxicity data. The agricultural-use criteria (table 13) apply to water in Colorado that is used or considered suitable for irrigation of crops grown in Colorado and

Table 13. Drinking-water regulations and aquatic-life criteria of the U.S. Environmental Protection Agency and agriculturaluse criteria of the State of Colorado

[MCL, maximum contaminant level (enforceable); SMCL, secondary maximum contaminant level (not enforceable); chronic criteria are for protection of aquatic life from adverse effects such as reproductive problems caused by long-term exposure; acute criteria are for protection of aquatic life from lethal effects; $\mathrm{mg} / \mathrm{L}$, milligrams per liter; --, no criterion; $\mu \mathrm{g} / \mathrm{L}$, micrograms per liter]

\begin{tabular}{|c|c|c|c|c|c|}
\hline \multirow{2}{*}{ Constituent } & \multicolumn{2}{|c|}{ Drinking-water regulations } & \multicolumn{2}{|c|}{ Aquatic-life criteria ${ }^{4}$} & \multirow{2}{*}{$\begin{array}{l}\text { Agricultural-use } \\
\text { criteria }^{6}\end{array}$} \\
\hline & $M C L^{1,2}$ & SMCL $^{3}$ & Chronic & Acute & \\
\hline Sulfate $(\mathrm{mg} / \mathrm{L})$ & -- & 250 & -- & -- & - \\
\hline Chloride (mg/L) & -- & 250 & -- & -- & -- \\
\hline Dissolved solids (mg/L) & -- & 500 & -- & -- & - \\
\hline Nitrate (mg/L) & 10 & -- & -- & -- & 100 \\
\hline Arsenic $(\mu \mathrm{g} / \mathrm{L})$ & 50 & -- & 190 & 360 & 100 \\
\hline Boron $(\mu \mathrm{g} / \mathrm{L})$ & -- & - & -- & -- & 750 \\
\hline Cadmium $(\mu \mathrm{g} / \mathrm{L})$ & 5 & -- & $\mathbf{a}_{4}$ & ${ }^{a} 24$ & 10 \\
\hline Chromium $(\mu \mathrm{g} / \mathrm{L})$ & 100 & -- & 11 & 16 & 100 \\
\hline Copper $(\mu \mathrm{g} / \mathrm{L})$ & - & 1,000 & ${ }^{\mathbf{a}} 47$ & a81 & 200 \\
\hline Lead $(\mu \mathrm{g} / \mathrm{L})$ & 50 & - & $a_{25}$ & ${ }^{a} 633$ & 100 \\
\hline Mercury $(\mu \mathrm{g} / \mathrm{L})$ & 2 & -- & .012 & 2.4 & - \\
\hline Selenium $(\mu \mathrm{g} / \mathrm{L})$ & 50 & - & $5_{5}$ & $s_{20}$ & 20 \\
\hline $\operatorname{Zinc}(\mu \mathrm{g} / \mathrm{L})$ & - & 5,000 & ${ }^{a} 414$ & $a_{458}$ & 2,000 \\
\hline
\end{tabular}

${ }^{2}$ Criteria are based on water hardness. Values were computed using a water hardness of 500 milligrams per liter.

References are indicated by the following numbers:

${ }^{1}$ U.S. Environmental Protection Agency, 1988a (MCL for nitrate, arsenic, lead, and mercury).

${ }^{2}$ U.S. Environmental Protection Agency, 1991 (MCL for cadmium, chromium, and selenium).

${ }^{3}$ U.S. Environmental Protection Agency, $1988 \mathrm{~b}$.

${ }^{4}$ U.S. Environmental Protection Agency, 1986.

${ }^{5}$ U.S. Environmental Protection Agency, 1987.

${ }^{6}$ Colorado Department of Health, 1989. 
that is not hazardous as drinking water for livestock (Colorado Department of Health, 1989). Three of the water-quality sites are located in Utah (sites ME4, SJ3, and GW); however, the Colorado agricultural-use criteria were used for comparison to the water-quality data collected in Utah for the reconnaissance investigation. Except for selenium, the agricultural-use criteria for Utah (Utah Department of Health, 1988) are the same as those listed in table 13. The selenium criterion for agricultural use in Utah is $50 \mu \mathrm{g} / \mathrm{L}$ (Utah Department of Health, 1988) instead of $20 \mu \mathrm{g} / \mathrm{L}$; that difference in the selenium criterion did not affect interpretation of results.

The number of water samples collected in the Dolores Project area that had constituent concentrations exceeding the various guidelines are summarized in table 14. The aquatic-life criteria for cadmium, copper, lead, and zinc (table 13) were computed using equations based on water hardness. A water hardness of $500 \mathrm{mg} / \mathrm{L}$ was used to compute the aquatic-life criteria listed in table 13 for those four trace elements. The water hardness of individual samples, which ranged from 52 to $3,200 \mathrm{mg} / \mathrm{L}$ (table 22 ), was used for determination of the number of samples listed in table 14 that exceeded aquatic-life criteria.

Many streams in Colorado have been classified by the State according to various beneficial-use categories and include domestic use, recreational use, protection of aquatic life, and agricultural use (Colorado Department of Health, 1989). The State adopted the drinking-water regulations and aquatic-life criteria of the U.S. Environmental Protection Agency to develop State water-quality standards. However, not all streams in Colorado have State numeric standards for trace elements because of the use classifications assigned to the stream or because the standards have not been determined. In the Dolores Project area, only

Table 14. Number of water samples collected in the Dolores Project area that had constituent concentrations exceeding drinking-water regulations and aquatic-life criteria of the U.S. Environmental Protection Agency and exceeded agricultural-use criteria of the State of Colorado

[MCL, maximum contaminant level; SMCL, secondary maximum contaminant level; number of samples is 79 ; --, no applicable regulation or criterion]

\begin{tabular}{|c|c|c|c|c|c|}
\hline \multirow{2}{*}{ Constituent } & \multicolumn{2}{|c|}{ Drinking-water regulations } & \multicolumn{2}{|c|}{ Aquatic-life criteria } & \multirow{2}{*}{ Agricuitural use } \\
\hline & MCL & SMCL & Chronic & Acute & \\
\hline Sulfate & -- & 58 & -- & -- & -- \\
\hline Chloride & -- & 6 & -- & -- & -- \\
\hline Dissolved solids & -- & 63 & -- & -- & -- \\
\hline Nitrate $^{1}$ & 2 & -- & -- & -- & 0 \\
\hline Arsenic & 0 & -- & 0 & 0 & 0 \\
\hline Boron & -- & - & -- & -- & 0 \\
\hline Cadmium & 0 & -- & 22 & 0 & 0 \\
\hline Chromium & 0 & -- & 0 & 0 & 0 \\
\hline Copper & -- & 0 & 0 & 0 & 0 \\
\hline Lead & 0 & -- & 0 & 0 & 0 \\
\hline Mercury & 0 & -- & $3_{11}$ & 0 & -- \\
\hline Selenium & 1 & -- & 19 & 1 & 1 \\
\hline Zinc & -- & 0 & 0 & 0 & 0 \\
\hline
\end{tabular}

\footnotetext{
${ }^{1}$ Concentrations of nitrite plus nitrate as nitrogen compared to regulations and criterion for nitrate.

${ }^{2}$ The chronic criterion for cadmium for three samples from Summit Reservoir was less than the analytical reporting limit of 1 microgram per liter for cadmium.

${ }^{3}$ Number of samples that exceeded criterion may be greater; the reporting limit for mercury was 0.1 microgram per liter; the chronic criterion for mercury was 0.012 microgram per liter.
} 
Mc Elmo Creek, the Mancos River, and the San Juan River have State water-quality standards for trace elements (Colorado Department of Health, 1986). Therefore, readers are advised that the information in table 14 used for evaluation of the water-quality data was not based on the State stream-classification system.

The water-quality data also were evaluated by comparing constituent concentrations in samples collected at reference sites, which are upstream from irrigated areas of the Dolores Project, to constituent concentrations in samples collected at sites downstream from irrigated areas. These comparisons could indicate if irrigation drainage was affecting water quality of streams in the Dolores Project area. The comparative information was used with the drinking-water regulations and water-quality criteria to determine if irrigation drainage from the Dolores Project was contributing potentially harmful constituents to water.

\section{Dissolved Solids and Major Constituents}

The water samples collected in the Dolores Project area were characterized by large dissolvedsolids and sulfate concentrations compared to drinkingwater regulations (tables 13 and 14). Concentrations in many samples exceeded the secondary maximum contaminant level (SMCL) for dissolved solids and sulfate (table 14). Samples that exceeded the SMCL's were collected at sites in the long-term irrigated area of the MVIC, in newly irrigated areas, and in non-irrigated areas. Only 16 of 79 water samples had dissolvedsolids concentrations less than $500 \mathrm{mg} / \mathrm{L}$; those samples were collected at the two outflow sites from McPhee Reservoir (sites GD and DT), Summit, Puett, and Totten Reservoirs (sites SU, PU, and TT), and the San Juan River at Four Corners (site SJ1 in table 22).

Most samples collected from streams in the MVIC area had dissolved-solids concentrations greater than $1,000 \mathrm{mg} / \mathrm{L}$, and all samples collected in the MVIC area during the pre-irrigation season (late March and April) in 1990 had concentrations greater than $1,500 \mathrm{mg} / \mathrm{L}$ except for the sample from Yellow Jacket Canyon at the mouth (site YJ2 in table 22). Almost all samples collected at sites in irrigated areas of the MVIC had dissolved-solids and sulfate concentrations exceeding the SMCL for those constituents. The concentration of nitrite plus nitrate as nitrogen $(17.0 \mathrm{mg} / \mathrm{L})$ in the sample collected at Navajo Wash (site NW) in March exceeded the MCL for nitrate of $10 \mathrm{mg} / \mathrm{L}$ (table 13). None of the streams or reservoirs in the MVIC area where drinking-water regulations were exceeded are used for municipal or domestic water supplies.
The maximum dissolved-solids concentration in a water sample collected downstream from irrigation drainage was $5,850 \mathrm{mg} / \mathrm{L}$ in the sample collected in March from Navajo Wash (site NW) (table 22). Water in Navajo Wash in March probably was irrigation drainage from gray (Mancos) soils in the southern MVIC area. Irrigation drainage from MVIC areas north of Mc Elmo Creek into Hartman Draw (sites HD1 and HD2), Alkali Canyon (site AK), Dawson Draw (site DD), and lower Yellow Jacket Canyon (site YJ2) had smaller dissolved-solids concentrations than Navajo Wash in the samples collected in the preirrigation season. The irrigated areas north of Mc Elmo Creek have more red soil than areas south of the creek, and red soils have less salt than gray soils (Bureau of Reclamation, 1988). Water samples from reference sites on Mc Elmo Creek at Highway 160 (site ME1) and Simon Draw (site SD) had dissolved-solids concentrations similar to dissolved-solids concentrations in streams draining irrigated land in the MVIC service area. However, stream discharge at sites ME1 and SD was considerably less than in the streams draining irrigated areas, and consequently, dissolved-solids loads were much less at reference sites than at sites downstream from irrigated areas.

Dissolved-solids concentrations in irrigation drain water diverted from McPhee Reservoir were about $160 \mathrm{mg} / \mathrm{L}$ based on samples collected in May and in August from the Dolores Tunnel (site DT) and Great Cut Dike (site GD) (table 22). This concentration is much less than the dissolved-solids concentrations in Mc Elmo Creek and other streams draining the MVIC area, indicating a substantial increase of dissolvedsolids concentration in irrigation drain water. Water samples collected from the Dolores Tunnel and the Great Cut Dike were a calcium bicarbonate type (assuming most of the alkalinity was bicarbonate at the pH of the samples); water samples from Mc Elmo Creek and tributary streams were a mixed cation sulfate type.

In the Dove Creek area (newly irrigated areas between Yellow Jacket Canyon and the town of Dove Creek), water samples collected from a small tributary of upper Yellow Jacket Canyon (site YJ1), Woods Canyon (site WC), and Cahone Canyon (site $\mathrm{CH}$ ) probably consisted of irrigation drainage from newly irrigated areas (since 1987). No sample was collected at site WC in July because there was no flow at this site, although there was irrigation in the drainage basin upstream from the site. In 1990, there was no irrigation upstream from site CR in Cross Canyon; therefore, site CR was a reference site for the Dove Creek area. On October 30,1990, water samples were collected from three shallow observation wells (sites OW1, 
OW2, and OW3) that were used by the Bureau of Reclamation to monitor ground-water levels.

Concentrations of dissolved solids and sulfate exceeded drinking-water regulations (table 13) in all samples collected at stream sites in the Dove Creek area (table 22); however, none of these streams are used for domestic water supplies. The seasonal variation of dissolved-solids concentrations (table 22) in upper Yellow Jacket Canyon (site YJ1) and Cahone Canyon (site $\mathrm{CH}$ ) are indicative of irrigation effects. The lack of seasonal variation of dissolved-solids and major-ion concentrations in Cross Canyon (site CR) (table 22) indicates that the water at site CR in 1990 probably was natural ground-water discharge. Although dissolvedsolids concentrations in the irrigation drainage from the Dove Creek area are similar to the concentrations in drainage in the MVIC area, the stream discharges, and subsequently the dissolved-solids loads, are much smaller in the Dove Creek area than in the MVIC area (table 22). As more land is brought into irrigation, the amount of irrigation return flow and drainage probably will increase in the Dove Creek area.

Sulfate comprised a large percentage of the anion composition of samples collected in the Dove Creek area, but the cation composition varied. The cation composition primarily was calcium in the tributary of Yellow Jacket Canyon, mixed calcium and magnesium in Woods Canyon, and magnesium in Cahone Canyon.
Dissolved-solids and major-ion concentrations in samples from three observation wells (sites OW1, OW2, and OW3) in the Dove Creek area were variable. Site OW1 is located in a tributary drainage of Cross Canyon in an area where irrigation began in the summer of 1990. The sample from site OW1 had less dissolved solids than other samples from the Dove Creek area. Site OW2 is located in the Cahone Canyon drainage upstream from site $\mathrm{CH}$ (fig. 1), and the dissolvedsolids concentration and water composition for water samples collected in the fall of 1990 at sites OW2 and $\mathrm{CH}$ were similar (table 22). Site OW3 is in a tributary drainage of Sandstone Canyon and is located about $2.5 \mathrm{mi}$ northeast of site WC. Concentrations of dissolved solids and major ions in samples collected in the fall of 1990 at sites OW3 and WC were about equal (table 22).

\section{Monthly measurements of water levels during} 1990-91 (J.P. Alcon, Bureau of Reclamation, written commun., 1992) in the three sampled observation wells are shown in figure 7. The rise in water levels in well OW1 in 1991 compared to 1990 was caused by increased irrigation of nearby land in 1991. The water levels in wells OW2 and OW3 did not change substantially until after the spring of 1991, when the water level in both wells decreased about $3 \mathrm{ft}$ by September (fig. 7).

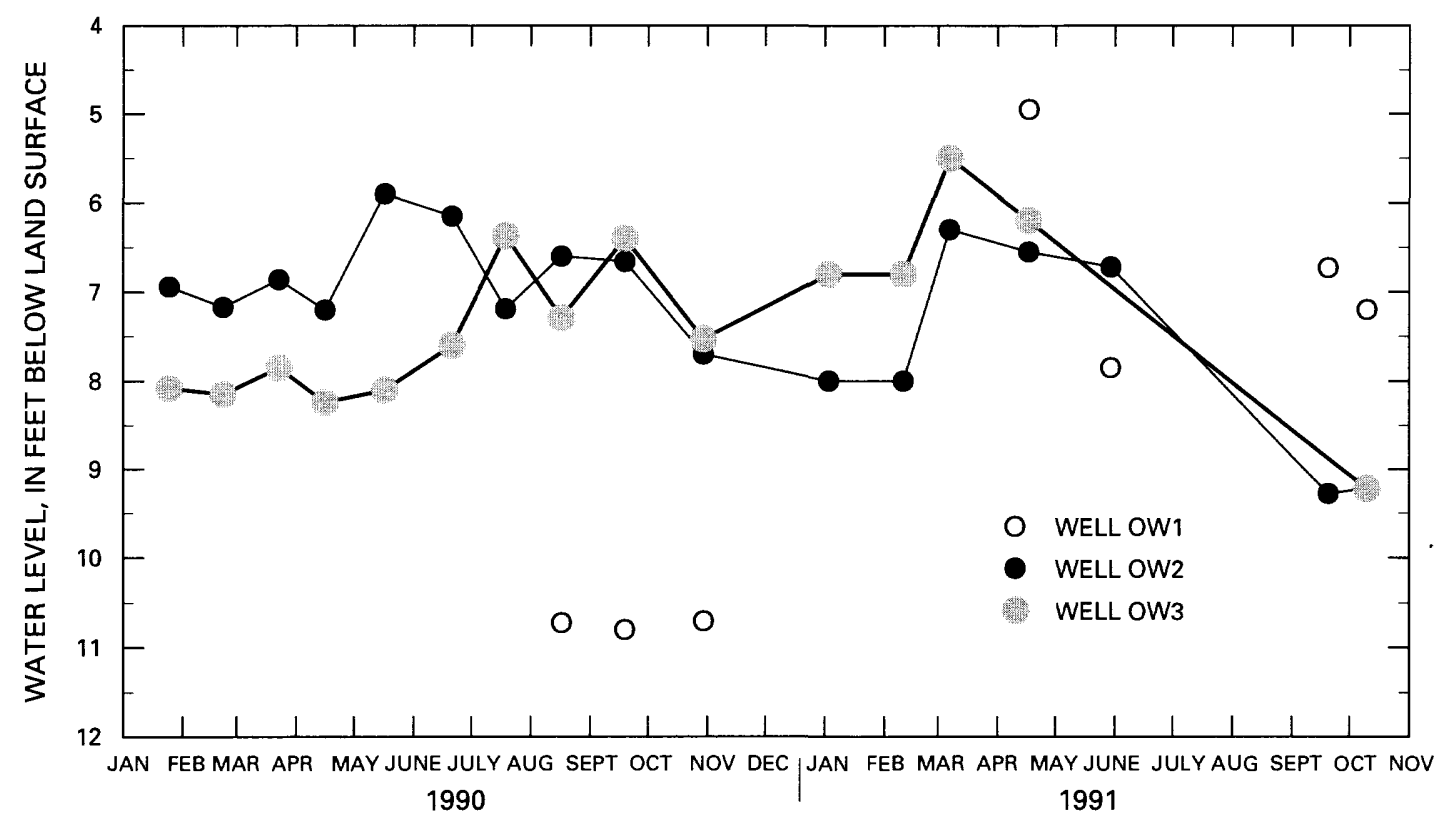

Figure 7. Water-level measurements for wells OW1, OW2, and OW3, January 1990-October 1991. 
Dissolved-solids and sulfate concentrations in all samples from the Mancos River (sites MN1 and MN2 in table 22) exceeded the SMCL for those constituents (table 13). The lower Mancos River is not used for water supplies. Dissolved-solids concentrations in the Mancos River were greater than $1,000 \mathrm{mg} / \mathrm{L}$, and water samples were a mixed cation sulfate water type. The washes draining land to be irrigated in the Towaoc area had no flow during the reconnaissance investigation in 1990.

The dissolved-solids and sulfate concentrations in the sample collected in July from the San Juan River at Four Corners (site SJ1) exceeded the SMCL (table 13) for those constituents. Dissolved-solids concentrations in the three samples collected from the San Juan River at Mexican Hat (site SJ3 in table 22) exceeded the SMCL for dissolved solids, and the sulfate concentrations in the three samples equaled or exceeded the SMCL for sulfate. The San Juan River is used for water supplies for the small towns of Aneth, Montezuma Creek, Bluff, and Mexican Hat in Utah (fig. 2).

The water samples collected from the San Juan River were a calcium sodium sulfate type, and most constituent concentrations were slightly greater at Mexican Hat (site SJ3) than at Four Corners (site SJ1). The gain in dissolved-solids load of 2,040 tons/d between sites SJ1 and SJ3 on July 17 (table 22) primarily was caused by inflow from Mc Elmo Creek (site ME4, table 22), which consisted of irrigation return flow from the MVIC area and runoff caused by thunderstorms. The Mancos River also may contribute large quantities of dissolved solids to the San Juan River. The confluence of the Mancos and San Juan Rivers is about $3 \mathrm{mi}$ upstream from site $\mathrm{SJ} 1$, and site MN2 on the Mancos River is about 2 mi upstream from the confluence (fig. 1). For the samples collected on July 17, the dissolved-solids load at site MN2 accounted for about 14 percent of the dissolved-solids load at site SJ1, and for samples collected on November 6 and 7, the dissolved-solids load at site MN2 accounted for about 10 percent of the load at site SJ1. The three water samples collected from the seep area at Aneth, Utah (site GW in table 22) had dissolved-solids concentrations that ranged from 8,210 to $8,730 \mathrm{mg} / \mathrm{L}$, and about 75 percent of the dissolved solids was comprised of sodium chloride. Data for site GW indicate that ground water could be a source of dissolved solids and other constituents to the San Juan River downstream from the Dolores Project.

\section{Trace Elements}

Many trace-element concentrations in samples collected from the Dolores Project area (table 22) were equal to or less than analytical reporting limits. A statistical summary of trace-element data is listed in table 15 . The only trace-element concentrations that exceeded the drinking-water regulations or aquatic-life criteria of the U.S. Environmental Protection Agency or the Colorado agricultural-use criteria (table 13) were cadmium, mercury, and selenium (table 14).

Table 15. Statistical summary of trace-element concentrations in water samples collected in the Dolores Project area in 1990

[Analyses by U.S. Geological Survey; concentrations in micrograms per liter; number of detections is the number of samples that had concentrations equal to or greater than the analytical reporting limit; <, less than]

\begin{tabular}{lccccc}
\hline $\begin{array}{c}\text { Trace } \\
\text { element }\end{array}$ & $\begin{array}{c}\text { Num- } \\
\text { ber } \\
\text { of } \\
\text { sam- } \\
\text { ples }\end{array}$ & $\begin{array}{c}\text { Num- } \\
\text { ber of } \\
\text { detec- } \\
\text { tions }\end{array}$ & Median & $\begin{array}{c}\text { Maxi- } \\
\text { mum }\end{array}$ & $\begin{array}{c}\text { Mini- } \\
\text { mum }\end{array}$ \\
\hline Arsenic & 79 & 41 & 1 & 12 & $<1$ \\
Boron & 79 & 75 & 110 & 720 & $<10$ \\
Cadmium & 79 & 19 & $<1$ & 4 & $<1$ \\
Chromium & 79 & 22 & $<1$ & 4 & $<1$ \\
Copper & 79 & 72 & 1 & 15 & $<1$ \\
Lead & 79 & 9 & $<1$ & 3 & $<1$ \\
Mercury & 79 & 11 & $<1$ & 1.2 & $<.1$ \\
Molybdenum & 79 & 50 & 1 & 16 & $<1$ \\
Selenium & 79 & 36 & $<1$ & 88 & $<1$ \\
Vanadium & 79 & 60 & 2 & 48 & $<1$ \\
& & & & & \\
Zinc & 79 & 46 & 4 & 35 & $<3$ \\
Uranium & 77 & 66 & 5.0 & 45 & $<1.0$ \\
\hline
\end{tabular}

\section{Cadmium}

Cadmium was detected (reporting limit $1 \mu \mathrm{g} / \mathrm{L}$ ) in 19 samples (table 15) collected at 16 sites; however, only two concentrations of cadmium exceeded the chronic criterion for aquatic life based on water hardness of individual samples. The cadmium concentration of $2 \mu \mathrm{g} / \mathrm{L}$ in the near-surface sample collected in November from Summit Reservoir (site SU, table 22) exceeded the hardness-based criterion of about $1 \mu \mathrm{g} / \mathrm{L}$ for that sample. The cadmium concentration of $4 \mu \mathrm{g} / \mathrm{L}$ in the near-bottom sample collected in November from Puett Reservoir (site PU) exceeded the hardness-based 
criterion of about $2 \mu \mathrm{g} / \mathrm{L}$ for that sample. Summit and Puett Reservoirs are reference sites located outside the MVIC area. Cadmium was detected in at least one water sample from most of the sites within the MVIC service area and in three of the six water samples collected from the San Juan River. The only part of the Dolores Project area where cadmium was not detected in water samples was the Dove Creek area. Mine drainage in the upper Dolores River basin may have been a potential source of cadmium in the irrigation water diverted from the Dolores River basin.

\section{Mercury}

Mercury was detected (reporting limit $0.1 \mu \mathrm{g} / \mathrm{L}$ ) in 11 water samples (table 15) collected at 9 sites in the Dolores Project area during 1990 at concentrations ranging from 0.1 to $1.2 \mu \mathrm{g} / \mathrm{L}$ (table 22 ). The maximum mercury concentration of $1.2 \mu \mathrm{g} / \mathrm{L}$ was in the sample collected in July from the seep area along the San Juan River at Aneth, Utah (site GW) (table 22). All samples in which mercury was detected exceeded the chronic criterion for mercury $(0.012 \mu \mathrm{g} / \mathrm{L})$; however, mercury concentrations reported as less than $0.1 \mu \mathrm{g} / \mathrm{L}$ (table 22) cannot be compared to the chronic criterion because $0.1 \mu \mathrm{g} / \mathrm{L}$ is greater than the criterion concentration. In the newly irrigated areas, mercury was detected in one sample from Cahone Canyon and in the samples from wells OW2 and OW3. Six of the 11 samples in which mercury was detected were collected at reference sites, which are outside irrigated areas of the Dolores Project. Mercury was not detected in the outflow from McPhee Reservoir (sites DT and GD) nor was mercury detected in samples from the San Juan River.

The mercury data collected for the reconnaissance investigation represent the dissolved mercury in water because the samples were filtered through $0.45 \mu \mathrm{m}$ filters prior to analysis. Mercury concentrations in unfiltered water samples can be greater than the concentrations in filtered samples because fluvial transport of some trace elements, including mercury, is dominated by the suspended-sediment phase (Hem, 1985; Horowitz, 1991). Although dissolved mercury was not detected in outflow from McPhee Reservoir (four samples), mercury transport into the Dolores Project area could occur on the suspended sediment in the water. As with cadmium, the mined areas in the upper Dolores River basin could be a source of mercury to the Dolores River and, subsequently, to the irrigation water diverted into the Dolores Project area.

\section{Selenium}

Selenium was detected (reporting limit $1 \mu \mathrm{g} / \mathrm{L}$ ) in 36 water samples (table 15) collected at 15 sites. Selenium concentrations in water samples collected at stream sites in 1990 are plotted in figures 8 and 9. The

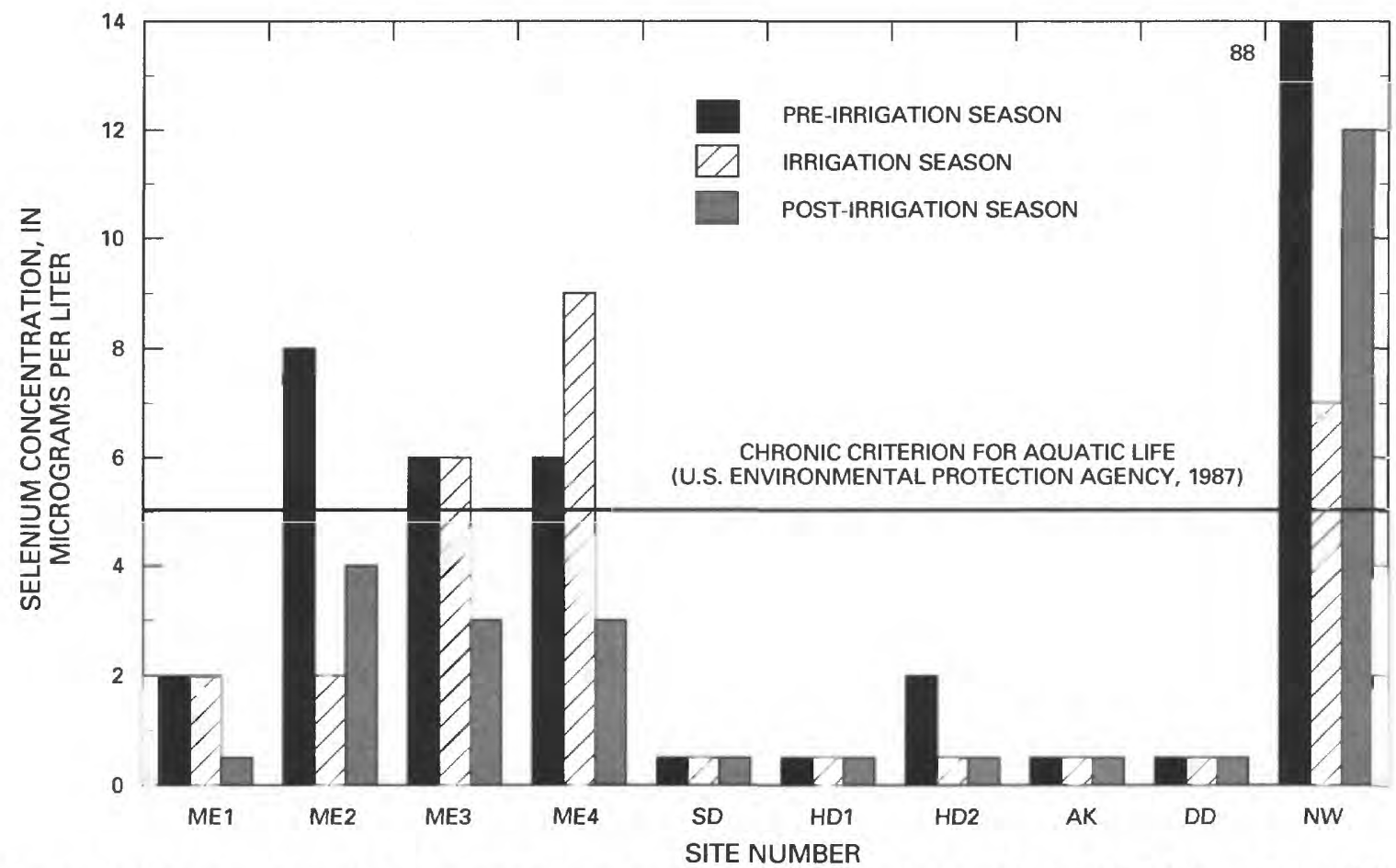

Figure 8. Concentrations of selenium in surface-water samples from Mc Elmo Creek (ME), Simon Draw (SD), Hartman Draw (HD), Alkali Canyon (AK), Dawson Draw (DD), and Navajo Wash (NW) in 1990. (Concentrations plotted as 0.5 were reported as less than 1 microgram per liter.) 


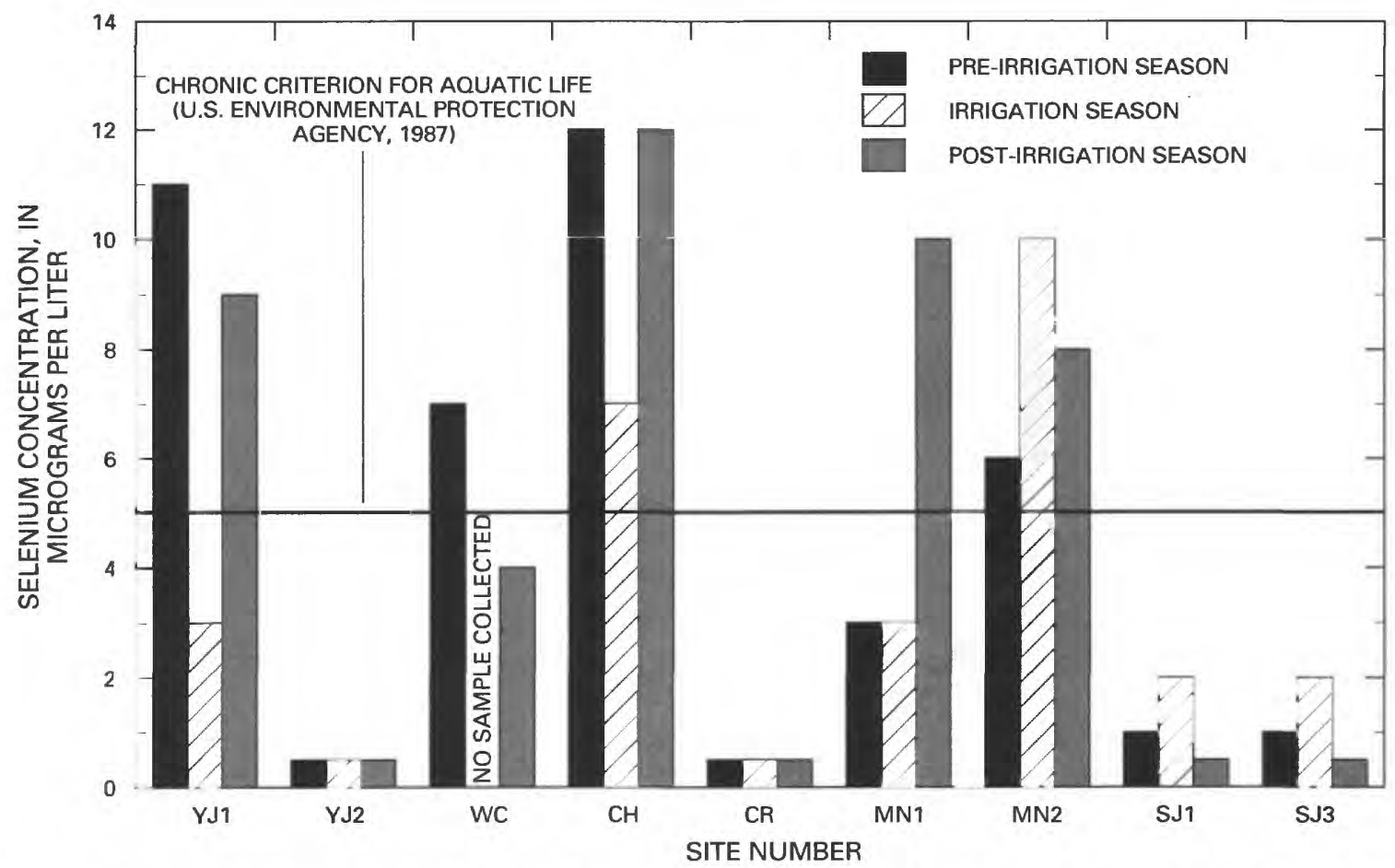

Figure 9. Concentrations of selenium in surface-water samples from Yellow Jacket Canyon (YJ), Woods Canyon (WC), Cahone Canyon (CH), Cross Canyon (CR), the Mancos River (MN), and the San Juan River (SJ) in 1990. (Concentrations plotted as 0.5 were reported as less than 1 microgram per liter.)

samples plotted for the pre-irrigation season were collected in late March and early April, samples for the irrigation season were collected in July, and samples for the post-irrigation season were collected in November. Only one selenium concentration was greater than $1 \mu \mathrm{g} / \mathrm{L}$ in the samples collected from outflow from McPhee Reservoir (sites DT and GD), from reservoirs (sites SU, PU, and TT), or at ground-water sites (sites OW1, OW2, OW3, and GW). That one sample was collected at site OW1 and had a selenium concentration of $7 \mu \mathrm{g} / \mathrm{L}$ (table 22). Therefore, selenium concentrations for those nine sites were not plotted.

The only selenium concentration in a water sample from the Dolores Project area that exceeded the MCL for selenium $(50 \mu \mathrm{g} / \mathrm{L})$ was $88 \mu \mathrm{g} / \mathrm{L}$ in a sample collected in March 1990 from Navajo Wash (site NW) (fig. 8). Navajo Wash is not used for domestic water supplies. The selenium concentration in 18 water samples from streams (figs. 8 and 9) and in the sample from well OW1 (table 22) exceeded the chronic aquatic-life criterion of $5 \mu \mathrm{g} / \mathrm{L}$. Lemly and Smith (1987) reported that selenium concentrations greater than 2 to $5 \mu \mathrm{g} / \mathrm{L}$ in water may cause reproductive failure or mortality in fish and waterfowl because of food-chain bioaccumulation. The selenium concentration in the sample collected in March at site NW also was the only concentration that exceeded the acute aquatic-life criterion and the agricultural-use criterion of $20 \mu \mathrm{g} / \mathrm{L}$.

Selenium was detected in all samples from Mc Elmo Creek that were collected within or downstream from the MVIC area (sites ME2, ME3, and ME4) at concentrations that ranged from 2 to $9 \mu \mathrm{g} / \mathrm{L}$ (fig. 8). Concentrations of selenium in 5 of the 10 samples collected at sites ME2, ME3, and ME4 (table 22) exceeded the chronic aquatic-life criterion. Based on selenium-load calculations using the stream-discharge and selenium data for Mc Elmo Creek, almost all the selenium in Mc Elmo Creek came from areas downstream from site ME1. Irrigation water from $\mathrm{McPhee}$ Reservoir (sites DT and GD) had selenium concentrations less than $1 \mu \mathrm{g} / \mathrm{L}$ (table 22).

There were distinct differences in selenium concentrations in tributary streams that drain the MVIC area. Selenium concentrations in samples from Navajo Wash (site NW) (fig. 8) were much larger than the concentrations in samples from Hartman Draw (sites HD1 and HD2), Alkali Canyon (site AK), Dawson Draw (site DD), and lower Yellow Jacket Canyon (site YJ2) (figs. 8 and 9). Selenium was detected in only 1 of the 15 samples collected from the sites on tributaries draining MVIC areas north of Mc Elmo Creek. The sample collected in the pre-irrigation season from Hartman 
Draw near the mouth (site HD2) had $2 \mu \mathrm{g} / \mathrm{L}$ of selenium. Navajo Wash drains irrigated areas on gray (Mancos) soils south of Cortez; the streams north of Mc Elmo Creek drain irrigated areas on red soils or mixed red and gray soils. If selenium concentrations in Navajo Wash are typical of selenium concentrations in irrigation drainwater from gray-soil areas south of Mc Elmo Creek, then irrigation drainage from gray-soil areas may be the primary source of selenium to Mc Elmo Creek.

In contrast to the northern MVIC area, selenium was detected (range of concentrations 3 to $12 \mu \mathrm{g} / \mathrm{L}$ ) in all samples from the Dove Creek area that were collected from upper Yellow Jacket Canyon (site YJ1), Woods Canyon (site WC), and Cahone Canyon (site $\mathrm{CH}$ ) (fig. 9 and table 22). Those three sites are downstream from newly irrigated areas (since 1987). The selenium concentration in six of the eight samples from sites YJ1, WC, and $\mathrm{CH}$ exceeded the chronic aquatic-life criterion of $5 \mu \mathrm{g} / \mathrm{L}$. Water samples collected at the three sites during the pre- and postirrigation seasons probably were comprised of shallow irrigation drainage from newly irrigated areas. There was a small amount of surface return flow in Cahone Canyon at site $\mathrm{CH}$ in July. Stream discharges measured at sites $\mathrm{YJ} 1, \mathrm{WC}$, and $\mathrm{CH}$ were less than $0.25 \mathrm{ft}^{3} / \mathrm{s}$; consequently, selenium loads in the newly irrigated areas were very small. Selenium was not detected in samples from Cross Canyon (site CR), the reference site for the Dove Creek area (fig. 9).

Irrigated land is on red soils throughout the Dove Creek area. Possibly, the long-term irrigation and the high application rates may have leached most of the soluble selenium from soils in the northern MVIC area, but in the Dove Creek area, the soluble selenium has not been leached from the soil. Selenium analyses have not been done on red soils from the Dove Creek area; however, the Bureau of Reclamation collected selenium data for red soils in the western part of the Towaoc area. Selenium concentrations in these soil samples ranged from 0.1 to $0.6 \mu \mathrm{g} / \mathrm{g}$, indicating that there is some selenium in red soils that have never been irrigated. The selenium concentrations in the water samples collected in 1990 at sites YJ1, WC, and CH may be indicative of selenium concentrations in irrigation drainage from red soils under initial leaching conditions.

The Mancos River drains extensive areas of Mancos Shale. Selenium in water samples from the Mancos River ranged from 3 to $10 \mu \mathrm{g} / \mathrm{L}$ (sites $\mathrm{MN} 1$ and MN2 in fig. 9 and table 22). Selenium sources in the Mancos River basin include irrigation drainage from the Mancos Project, located upstream from the Dolores
Project; irrigation drainage from the MVIC area discharging from Navajo Wash; and natural sources. Despite low stream discharge during 1990, selenium concentrations in the San Juan River (sites SJ1 and SJ3) did not exceed $2 \mu \mathrm{g} / \mathrm{L}$ (fig. 9). Because selenium concentrations at sites SJ1 and SJ3 were equal for the three sampling surveys in 1990 , outflow from the Dolores Project area did not have a measurable effect on selenium concentrations in water in the San Juan River.

\section{Other trace elements}

The only samples that had arsenic concentrations greater than $3 \mu \mathrm{g} / \mathrm{L}$ were collected at the ground-water site at Aneth, Utah (site GW); concentrations were 11 and $12 \mu \mathrm{g} / \mathrm{L}$ (table 22 ). Water at site $\mathrm{GW}$ discharges into the San Juan River. The maximum boron concentration of $720 \mu \mathrm{g} / \mathrm{L}$ (table 15) was in the sample collected from Navajo Wash during the pre-irrigation season. That sample also had the maximum selenium concentration. Boron concentrations in Mc Elmo Creek downstream from the MVIC area (sites ME2, ME3, and ME4) ranged from 110 to $260 \mu \mathrm{g} / \mathrm{L}$, compared to boron concentrations equal to or less than $20 \mu \mathrm{g} / \mathrm{L}$ in irrigation water from McPhee Reservoir (sites DT and GD; table 22). Analogous to dissolved solids and selenium, irrigation drainage from the MVIC area apparently is a source of boron to Mc Elmo Creek. Copper concentrations did not exceed waterquality guidelines (table 14). The maximum copper concentration of $15 \mu \mathrm{g} / \mathrm{L}$ (table 15) was in the sample collected in July 1990 from the San Juan River at Four Corners (site SJ1). Thunderstorm runoff upstream from site SJ1 may have been the source of copper. Thunderstorm runoff also may have been the cause of the slightly larger molybdenum concentrations in Mc Elmo Creek at sites ME3 and ME4 in July (table 22).

The largest vanadium concentrations were in samples of ground water from reference sites, site GW at Aneth, Utah, and site CR in Cross Canyon. The maximum vanadium concentration of $48 \mu \mathrm{g} / \mathrm{L}$ (table 15) was in the sample collected at site GW in November 1990 (table 22). There were distinct seasonal differences of vanadium concentrations in stream samples. The median vanadium concentrations were less than $1 \mu \mathrm{g} / \mathrm{L}$ for pre-irrigation-season samples, $6 \mu \mathrm{g} / \mathrm{L}$ for the irrigation-season samples, and $1 \mu \mathrm{g} / \mathrm{L}$ for the post-irrigation-season samples. The maximum uranium concentration of $45 \mu \mathrm{g} / \mathrm{L}$ (table 15) was in the sample collected during the pre-irrigation season from Navajo Wash, the same sample that had the maximum selenium and boron concentrations. However, a 
number of the larger uranium concentrations were collected at reference sites, such as site ME1 on Mc Elmo Creek and site GW (table 22). There was a weak correlation between selenium and uranium concentrations for water samples collected in irrigated areas; the Spearman correlation coefficient was $\mathbf{0 . 6 5}$.

\section{Pesticides}

Fourteen samples collected in the Dolores Project area were analyzed for 6 herbicides (the first six compounds listed in table 23) and 10 organophosphate insecticides. The analytical reporting limit for all the compounds listed in table 23 was $0.01 \mu \mathrm{g} / \mathrm{L}$. The herbicides 2,4-D and dicamba were detected in most samples, and picloram was detected in five samples. The maximum pesticide concentration was $0.20 \mu \mathrm{g} / \mathrm{L}$ of 2,4-D for the downstream site on the Mancos River (site MN2) (table 23). Only one organophosphate insecticide was detected; malathion was reported at $0.01 \mu \mathrm{g} / \mathrm{L}$ in the sample from the lower site on Hartman Draw (site HD2). The pesticide concentrations in water samples were considerably less than the concentrations that may be harmful to aquatic life.

\section{Bottom Sediment}

Bottom-sediment samples were collected at 18 sites for trace-element and pesticide analysis during the reconnaissance investigation. The trace-element analyses for the less than $0.0625-\mathrm{mm}$ size fraction are listed in table 24 and for the less than 2-mm size fraction in table 25. The pesticide analyses are listed in table 26. Tables 24-26 are in the "Supplemental Data" section at the back of the report. A statistical summary of selected trace-element concentrations in bottom sediment is listed in table 16.

Most trace-element concentrations in samples collected from the Dolores Project area (tables 24 and 25) were not elevated compared to soil-baseline data or bottom-sediment data from previous reconnaissance investigations for the DOI Irrigation Drainage Program (table 17). The bottom-sediment data in table 17 were based on trace-element concentrations in 255 samples collected from 19 areas in the Western United States from 1986-88 (Severson and others, 1991). Traceelement data for bottom sediment in the project area were compared to the data in table 17 to identify outlier concentrations.

Median concentrations in the less than $0.0625-\mathrm{mm}$ size fraction for most of the trace elements in bottom sediment (table 16) were similar to the geo-
Table 16. Statistical summary of selected trace-element concentrations in bottom-sediment samples collected in the Dolores Project area in November 1990

[Analyses by U.S. Geological Survey; concentrations in micrograms per gram; <, less than]

\begin{tabular}{|c|c|c|c|}
\hline Trace element & Median & Maximum & Minimum \\
\hline \multicolumn{4}{|c|}{ LESS THAN 0.0625-MILLIMETER SIZE FRACTION } \\
\hline Arsenic & 4.8 & 7.8 & 3.4 \\
\hline Barium & 515 & 1,900 & 400 \\
\hline Beryllium & 1 & 2 & 1 \\
\hline Cadmium & $<2$ & $<2$ & $<2$ \\
\hline Chromium & 40 & 68 & 29 \\
\hline Copper & 19 & 25 & 11 \\
\hline Lead & 16 & 20 & 13 \\
\hline Lithium & 34 & 54 & 21 \\
\hline Manganese & 485 & 670 & 290 \\
\hline Mercury & .04 & .10 & $<.02$ \\
\hline Molybdenum & $<2$ & 6 & $<2$ \\
\hline Nickel & 18 & 30 & 10 \\
\hline Selenium & .5 & 4.3 & .1 \\
\hline Strontium & 240 & 720 & 130 \\
\hline Thorium & 13.1 & 21.1 & 8.7 \\
\hline Uranium & 5.0 & 10.3 & 3.7 \\
\hline Vanadium & 60 & 140 & 49 \\
\hline Zinc & 60 & 100 & 36 \\
\hline \multicolumn{4}{|c|}{ LESS THAN 2-MILLIMETER SIZE FRACTION } \\
\hline Arsenic & 4.0 & 8.5 & 1.9 \\
\hline Barium & 470 & 1,300 & 140 \\
\hline Beryllium & 1 & 2 & $<1$ \\
\hline Cadmium & $<2$ & $<2$ & $<2$ \\
\hline Chromium & 24 & 70 & 3 \\
\hline Copper & 11 & 28 & 3 \\
\hline Lead & 14 & 28 & 7 \\
\hline Lithium & 24 & 61 & 11 \\
\hline Manganese & 390 & 540 & 220 \\
\hline Mercury & .02 & .08 & $<.02$ \\
\hline Molybdenum & $<2$ & 3 & $<2$ \\
\hline Nickel & 11 & 31 & 2 \\
\hline Selenium & .4 & 3.6 & $<.1$ \\
\hline Strontium & 170 & 440 & 64 \\
\hline Thorium & 6.0 & 15.2 & 1.3 \\
\hline Uranium & 2.2 & 5.0 & .74 \\
\hline Vanadium & 38 & 150 & 10 \\
\hline Zinc & 40 & 110 & 12 \\
\hline
\end{tabular}

metric mean-concentrations for soils in the Western United States (table 17). Median concentrations in the less than 2-mm size fraction for almost all of the trace elements were less than the geometric means for soils. 
Table 17. Background geochemical data for soils in the Western United States and the observed range of trace-element concentrations in bottom-sediment samples collected for the U.S. Department of the Interior's Irrigation Drainage Program from 1986-88

[Soil data for Western United States modified from Shacklette and Boemgen (1984); baseline is the 95-percent expected range; bottomsediment data for the irrigation-drainage reconnaissance studies from Severson and others (1991); coarse fraction is the less than 2-millimeter size fraction; fine fraction is the less than 0.0625 -millimeter size fraction; concentrations in micrograms per gram; <, less than; --, not reported]

\begin{tabular}{|c|c|c|c|c|c|}
\hline \multirow{2}{*}{ Trace element } & \multicolumn{3}{|c|}{ Solls In Western United States } & \multicolumn{2}{|c|}{$\begin{array}{l}\text { Range of concentrations for bottom- } \\
\text { sediment data }\end{array}$} \\
\hline & $\begin{array}{c}\text { Goometrlc } \\
\text { mean }\end{array}$ & Range & Baseline & Fine fraction & Coarse fraction \\
\hline Arsenic & 5.5 & $<0.1-97$ & $1.4-22$ & $0.6-120$ & $0.6-59$ \\
\hline Barium & 580 & $70-5,000$ & $200-1,700$ & $32-2,200$ & $56-1,900$ \\
\hline Beryllium & .68 & $<1-15$ & $.13-3.6$ & $<1.0-3.0$ & $<1.0-3.0$ \\
\hline Chromium & 41 & $3-2,000$ & $8.5-200$ & $20-330$ & $1.0-300$ \\
\hline Cobalt & 7.1 & $<3-50$ & $1.8-28$ & $4.0-40$ & $2.0-39$ \\
\hline Copper & 21 & $2-300$ & $4.9-90$ & $5.0-520$ & $3.0-180$ \\
\hline Lead & 17 & $<10-700$ & $5.2-55$ & $<4.0-500$ & $<4.0-250$ \\
\hline Lithium & 22 & $5-130$ & $8.8-55$ & $10-220$ & $4.0-200$ \\
\hline Manganese & 380 & $30-5,000$ & $97-1,500$ & $66-4,500$ & $80-2,100$ \\
\hline Mercury & .046 & $<.01-4.6$ & $.0085-.25$ & $<.02-18$ & $<.02-20$ \\
\hline Molybdenum & .85 & $<3-7$ & $.18-4.0$ & $<2-73$ & $<2-54$ \\
\hline Nickel & 15 & $<5-700$ & $3.4-66$ & $8.0-170$ & $<2-160$ \\
\hline Selenium & .23 & $<.1-4.3$ & .039-1.4 & $<.1-85$ & $<.1-120$ \\
\hline Strontium & 200 & $10-3,000$ & $43-930$ & $59-1,600$ & $69-1,400$ \\
\hline Thorium & 9.1 & $2.4-31$ & $4.1-20$ & $<4.0-47$ & $<4.0-24$ \\
\hline Uranium & 2.5 & $.68-7.9$ & $1.2-5.3$ & -- & - \\
\hline Vanadium & 70 & $7-500$ & $18-270$ & $20-310$ & $5.0-220$ \\
\hline Zinc & 55 & $10-2,100$ & $17-180$ & $23-1,600$ & $10-860$ \\
\hline
\end{tabular}

One concentration of barium, two concentrations of lithium, and two concentrations of molybdenum (tables 24 and 25) were slightly greater than the upper baseline for soils. Six concentrations of selenium were greater than the upper baseline for soils $(1.4 \mu \mathrm{g} / \mathrm{g})$. The selenium concentrations in both size fractions (tables 24 and 25) in bottom sediment from Cahone Canyon (site $\mathrm{CH}$ ) and from the downstream site on the Mancos River (site MN2) exceeded $1.4 \mu \mathrm{g} / \mathrm{g}$. The selenium concentration in the less than $0.0625-\mathrm{mm}$ size fraction (table 24) in bottom sediment from Woods Canyon (site WC) and from Navajo Wash (site NW) exceeded $1.4 \mu \mathrm{g} / \mathrm{g}$. These four sites also had some of the larger selenium concentrations in water samples. The maximum concentrations of selenium in both size fractions (table 16) were in the sample collected from Cahone Canyon (site $\mathrm{CH}$ ). There were two concentra- tions of thorium that exceeded the upper baseline for soils $(20 \mu \mathrm{g} / \mathrm{g})$, and six concentrations of uranium that exceeded the upper baseline for soils $(5.3 \mu \mathrm{g} / \mathrm{g})$; all those concentrations were in samples of the less than 0.0625-size fraction (table 24).

The trace-element data for the Dolores Project area (tables 24 and 25) were compared to the range of trace-element concentrations in bottom sediment collected for previous DOI irrigation-drainage reconnaissance investigations (table 17). The bottom-sediment data in table 24 were compared to the range of concentrations for the fine size fraction listed in table 17, and the data in table 25 were compared to the range of concentrations for the coarse size fraction listed in table 17. Trace-element concentrations in both size fractions in bottom sediment from the Dolores Project area did not exceed maximum concentrations for the previous DOI 
investigations. The strontium concentration of $64 \mu \mathrm{g} / \mathrm{g}$ in the less than 2-mm size fraction for Hartman Draw near the mouth (site HD2 in table 25) was smaller than the minimum concentration for the coarse size fraction (table 17) reported by Severson and others (1991).

A number of concentrations of chromium, copper, lithium, manganese, nickel, thorium, uranium, vanadium, and zinc were smaller in the less than $2-\mathrm{mm}$ size fraction than in the less than $0.0625-\mathrm{mm}$ size fraction (tables 24 and 25). Some of the largest concentrations of several trace elements in bottom sediment were in samples from the three reservoirs (sites SU, PU, and TT) and the Mancos River (site MN2). Mercury was an element of concern in the Dolores Project area because of possible bioaccumulation through the food chain that could result in undesirable mercury concentrations in game fish. The only sites that had concentrations of mercury exceeding $0.04 \mu \mathrm{g} / \mathrm{g}$ in bottom sediment were Summit Reservoir (site SU) and Puett Reservoir (site PU) (tables 24 and 25).

Six pesticides were detected in bottomsediment samples collected in the Dolores Project area (table 26). The compounds detected were aldrin, chlordane, DDD, DDE, DDT, and dieldrin. DDE was detected in 10 of the 18 bottom-sediment samples collected in the Dolores Project area. The maximum concentration of a pesticide in bottom sediment was $5.5 \mu \mathrm{g} / \mathrm{kg}$ of DDD in the sample from Summit Reservoir (site SU, table 26), a reference site located outside irrigated areas of the Dolores Project. The largest pesticide concentrations were in samples collected at Summit Reservoir, Totten Reservoir (site TT), and Simon Draw (site SD). Those sites are located in the same general area northeast of Cortez (fig. 1).

\section{Biota}

\section{Data Interpretation}

Many chemical, physical, and biological factors affect the toxicity of environmental contaminants to biological organisms. Chemical and physical factors include contaminant type, chemical species or form, $\mathrm{pH}$, water temperature, dissolved oxygen, hardness, salinity, and multiple-chemical exposure (antagonism and synergism). Duration of exposure, quantity of contaminant, and exposure pathways from the environment to the organism also affect toxicity. Some trace elements are beneficial to organisms at small concentrations but may be toxic at larger concentrations. Biological and physiological factors affecting toxicity include species, age, sex, and health of the organism. Interpretation of contaminant concentrations in biota is difficult and complex and, in many cases, may not be possible using only data collected in field studies. One of the best methods for interpreting contaminant data is by comparison with data collected from other field studies and laboratory studies.

Concentrations of inorganic trace elements in biological samples are extremely variable. These data can be interpreted by comparison to available literature to determine if constituent concentrations in biota samples exceed concentrations that may be harmful to fish and wildlife or exceed guidelines for human consumption. A frequently used index for interpreting contaminant data for fish samples is the National Contaminant Biomonitoring Program (NCBP) of the U.S. Fish and Wildlife Service. Schmitt and Brumbaugh (1990) reported the 85th-percentile concentrations for arsenic, cadmium, copper, lead, mercury, selenium, and zinc for fish samples collected during 1976-84 throughout the United States. The 85 th percentile has been established by NCBP as an arbitrary concentration for distinguishing whole-body fish samples that have relatively large concentrations for the seven trace elements. The 85th percentile is not necessarily an indicator of potential hazards to fishery resources nor can it be used in place of regulatory standards. The NCBP means and percentiles were calculated using combined fish species, and it should be noted that there can be significant differences in selenium accumulation between species (Lemly, 1993). Nevertheless, NCBP data are still useful for comparison purposes. Concentrations listed in Schmitt and Brumbaugh (1990) are wet-weight concentrations; therefore, the dry-weight concentrations listed in table 27 for the seven trace elements were converted to wet-weight concentrations in the text to facilitate comparison to the 85th-percentile concentrations. (Tables 27-29 are in the "Supplemental Data" section at the back of the report). The NCBP also has collected data for organochlorine pesticides (Schmitt and others, 1990).

The NCBP 85th percentile was reported for several years within the sampling period, 1976-84 (Schmitt and Brumbaugh, 1990). The most recent compilation was for fish samples collected during 1984, and the 85th percentiles reported for 1984 are used in this report. Previous DOI reconnaissance investigations used 85 th percentiles based on earlier compilation periods. The 85th-percentile concentrations for the seven trace elements and the number of whole-body fish samples collected in the Dolores Project area that exceeded the 85th percentiles for 1984 are listed in table 18.

Biota samples were collected from the MVIC area and the Dove Creek area to compare effects from long-term irrigation to the effects from new irrigation. 
Table 18. National Contaminant Biomonitoring Program (NCBP) 85th-percentile concentrations for 1984 and the number of whole-body fish samples collected in the Dolores Project area that exceeded the 85th percentile for 1984

[Concentrations in micrograms per gram wet weight; NCBP 85th, NCBP 85th-percentile concentrations from Schmitt and Brumbaugh (1990); MVIC, Montezuma Valley Irrigation Company; N, total number of fish samples collected in April, July, and November 1990; numbers im parentheses are the number of exceedances expressed as a percentage of total number of samples in each group]

\begin{tabular}{|c|c|c|c|c|c|c|c|}
\hline \multirow[b]{2}{*}{$\begin{array}{c}\text { Trace } \\
\text { element }\end{array}$} & \multirow[b]{2}{*}{ NCBP 85th } & \multicolumn{6}{|c|}{ Number of samples exceeding 1984 NCBP 85th percentile } \\
\hline & & $\begin{array}{c}\text { Total } \\
(\mathrm{N}=181)\end{array}$ & $\begin{array}{l}\text { MVIC area } \\
\text { streams } \\
(\mathrm{N}=100)\end{array}$ & $\begin{array}{c}\text { Dove Creok } \\
\text { area } \\
(\mathrm{N}=3)\end{array}$ & $\begin{array}{c}\text { Mancos } \\
\text { River } \\
(\mathrm{N}=17)\end{array}$ & $\begin{array}{c}\text { San Juan } \\
\text { River } \\
(\mathbf{N}=31)\end{array}$ & $\begin{array}{c}\text { Reservoirs } \\
\quad(\mathrm{N}=\mathbf{3 0})\end{array}$ \\
\hline Arsenic & 0.27 & 7 & $7(7.0)$ & 0 & 0 & 0 & 0 \\
\hline Cadmium & .05 & 63 & $51^{1}(51.0)$ & $2(66.7)$ & $3^{1}(17.6)$ & $2^{1}(6.5)$ & $5(16.7)$ \\
\hline Copper & 1.0 & 83 & $48(48.0)$ & $1(33.3)$ & $13(76.5)$ & $16^{1}(51.6)$ & $5(16.7)$ \\
\hline Lead & .22 & 40 & $19^{1}(19.0)$ & 0 & $6^{1}(35.3)$ & $15^{1}(48.4)$ & 0 \\
\hline Mercury & .17 & 29 & $11(11.0)$ & 0 & $1(5.9)$ & 0 & $17(56.7)$ \\
\hline Selenium & .73 & 79 & $46(46.0)$ & $3(100.0)$ & $15(88.2)$ & $14(45.2)$ & 1 (3.3) \\
\hline Zinc & 34.20 & 44 & $32(32.0)$ & $2(66.7)$ & $3 \quad(17.6)$ & $6(19.4)$ & $1 \quad(3.3)$ \\
\hline
\end{tabular}

\footnotetext{
${ }^{1}$ Some fish samples had reporting limits greater than the NCBP 85th percentile.
}

In addition, biota samples were collected from the Mancos River to provide reference data for the Towaoc area, which will be irrigated in the future with water from the Dolores Project.

All drainage from the Dolores Project eventually discharges into the San Juan River. The San Juan River is habitat for two endangered fish species, the Colorado squawfish (Ptychocheilus lucius) and the razorback sucker (Xyrauchen texanus). A total of four adult Colorado squawfish were found in the San Juan River in 1988 (Platania, 1990), three in New Mexico and the fourth in Utah near the Four-Corners area. Nineteen young-of-year Colorado squawfish were found during 1987 and 1988. Six squawfish were located close to the confluence of Montezuma Creek and the San Juan River, two squawfish were in New Mexico near the confluence of the San Juan River and Mancos River ( $3 \mathrm{mi}$ upstream from and $0.5 \mathrm{mi}$ downstream from the confluence), and the remaining squawfish were located in the lower 24 river miles (downstream from Grand Gulch). In 1987, 18 adult razorback suckers were found in the San Juan River arm of Lake Powell. In 1988,10 adult razorback suckers were captured in the mouth of the San Juan River at Lake Powell in Utah.

Trace-element concentrations in nonendangered fish species collected at three sites on the San Juan River were used to indicate potential exposures to endangered fish species. Trace-element concentrations in flannelmouth sucker and bluehead sucker tissues may be indicative of selenium concentrations in the endangered razorback sucker, and concentrations in channel catfish may be indicative of selenium concentrations in Colorado squawfish. However, caution is advised when applying toxicity information across taxonomic groups. Trace-element concentrations in aquatic plant, aquatic invertebrate, and fish prey species may be indicative of possible dietary exposure through the food-web pathway.

Although biota samples were analyzed for an array of trace elements, major emphasis was placed on selenium, which has been associated with some irrigated areas in the Western United States. Also, mercury concentrations were emphasized because of concern about the transport of heavy metals from the Dolores River into the study area, especially into the reservoirs. The analytical results for the biological samples are listed in table 27. All elements for which toxicological information is readily available are discussed in the following "Trace Elements" section. Concentrations of other elements listed in table 27 are presented as background information for future studies.

\section{Trace Elements}

\section{Selenium in aquatic plants}

Fifty-four algae and aquatic-plant samples were collected in the Dolores Project area for trace-element analysis. Thirty-three of these samples were collected 
from streams in the MVIC area, one from a pond in the MVIC area, and 13 samples were collected from streams in the Dove Creek area. Three samples were collected from the San Juan River, and four were collected from reservoirs. Geometric mean selenium concentrations were calculated for vegetation samples (table 19) after excluding reference sites upstream from irrigation; Cross Canyon (site CR) from the Dove Creek area, and site ME1 on Mc Elmo Creek and Simon Draw (site SD) from the MVIC area. The geometric mean selenium concentrations in aquatic-plant and algae samples from the four areas were; $0.74 \mu \mathrm{g} / \mathrm{g}$ dry weight for streams in the MVIC area, $2.7 \mu \mathrm{g} / \mathrm{g}$ dry weight for the Dove Creek area, $0.63 \mu \mathrm{g} / \mathrm{g}$ dry weight for the San Juan River, and $0.45 \mu \mathrm{g} / \mathrm{g}$ dry weight for the reservoirs (table 19). The geometric mean selenium concentration for six aquatic-plant and algae samples collected from MVIC reference sites (sites ME1 and SD) was $1.0 \mu \mathrm{g} / \mathrm{g}$ dry weight (standard deviation 1.6). Thus, there was no apparent difference in selenium concentrations in aquatic plants and algae from sites within the irrigated MVIC area and reference sites.

Tabie 19. Statistical summary of selenium concentrations in selected biota samples collected in the Dolores Project area in 1990

[Concentrations in micrograms per gram dry weight; MVIC, Montezuma Valley Irrigation Company; N, number of samples; GM, geometric mean; GD, geometric deviation; --, statistic not computed; data for reference sites not included in statistics for Dove Creek and MVIC areas]

\begin{tabular}{|c|c|c|c|c|c|c|}
\hline Statistic & $\begin{array}{l}\text { Aquatic piants } \\
\text { and algae }\end{array}$ & $\begin{array}{c}\text { Aquatic } \\
\text { invertebrates }\end{array}$ & Fathead minnows & Speckled dace & Suckers & Carp \\
\hline \multicolumn{7}{|c|}{ MVIC AREA STREAMS } \\
\hline $\mathbf{N}$ & 27 & 23 & 19 & 17 & 44 & 5 \\
\hline GM & .74 & 1.7 & 3.4 & 4.9 & 1.5 & 4.2 \\
\hline GD & 1.9 & 2.2 & 1.7 & 1.4 & 1.9 & 1.2 \\
\hline Maximum & 4.3 & 9.3 & 11.0 & 8.7 & 9.3 & 5.2 \\
\hline Minimum & .30 & .62 & 1.4 & 2.8 & .49 & 3.7 \\
\hline \multicolumn{7}{|c|}{ DOVE CREEK AREA } \\
\hline $\mathbf{N}$ & 9 & 11 & 3 & 0 & 0 & 0 \\
\hline GM & 2.7 & 7.8 & 22.3 & -- & -- & -- \\
\hline GD & 1.7 & 2.0 & 1.2 & -- & -- & -- \\
\hline Maximum & 6.4 & 19.2 & 26.4 & -- & -- & -- \\
\hline Minimum & 1.3 & 2.0 & 18.4 & -- & -- & -- \\
\hline \multicolumn{7}{|c|}{ MANCOS RIVER } \\
\hline $\mathbf{N}$ & 0 & 5 & 2 & 1 & 8 & 3 \\
\hline GM & -- & 3.7 & 10.4 & 5.5 & 4.3 & 6.8 \\
\hline GD & - & 2.2 & 1.5 & - & 1.7 & 1.4 \\
\hline Maximum & -- & 11.2 & 14.0 & -- & 7.6 & 9.8 \\
\hline Minimum & - & 1.8 & 7.7 & - & 1.7 & 5.4 \\
\hline \multicolumn{7}{|c|}{ SAN JUAN RIVER } \\
\hline $\mathbf{N}$ & 3 & 1 & 0 & 3 & 20 & 4 \\
\hline GM & .63 & 2.5 & -- & 4.0 & 1.7 & 2.8 \\
\hline GD & 1.4 & -- & -- & 1.3 & 1.6 & 2.2 \\
\hline Maximum & .94 & -- & -- & 5.1 & 4.2 & 5.3 \\
\hline Minimum & .46 & -- & -- & 2.9 & .61 & .92 \\
\hline \multicolumn{7}{|c|}{ RESERVOIRS } \\
\hline $\mathbf{N}$ & 4 & 5 & 0 & 0 & 4 & 0 \\
\hline GM & .45 & .66 & -- & -- & 1.3 & -- \\
\hline GD & 1.4 & 1.1 & -- & -- & 1.1 & -- \\
\hline Maximum & .60 & .83 & - & -- & 1.4 & - \\
\hline Minimum & .30 & .60 & -- & -- & 1.2 & -- \\
\hline
\end{tabular}


Four aquatic-plant and algae samples collected at the reference site for the Dove Creek area (Cross Canyon at site $\mathrm{CR}$ ) had a geometric mean selenium concentration of $1.3 \mu \mathrm{g} / \mathrm{g}$ dry weight (standard deviation 3.0), compared to the geometric mean of $2.7 \mu \mathrm{g} / \mathrm{g}$ dry weight for the irrigated sites. The Dove Creek area had higher selenium concentrations in vegetation than did the MVIC area (fig. 10, table 19).

Lemly and Smith (1987) and Lemly (1993) recommended that $3 \mu \mathrm{g} / \mathrm{g}$ dry weight selenium be used as the toxic threshold for selenium transferred to consumer species of fish and wildlife through aquatic food chains. Only 5 of the 54 vegetation samples exceeded $3 \mu \mathrm{g} / \mathrm{g}$ dry weight selenium (table 27). One algae sample collected in Navajo Wash (site NW) in the MVIC area contained $4.3 \mu \mathrm{g} / \mathrm{g}$ dry weight selenium. In the Dove Creek area, one vegetation sample collected in Cahone Canyon contained $6.4 \mu \mathrm{g} / \mathrm{g}$ dry weight selenium, one sample from the Cross Canyon reference site contained $4.0 \mu \mathrm{g} / \mathrm{g}$ dry weight selenium, and two samples from Woods Canyon contained 3.3 and $5.8 \mu \mathrm{g} / \mathrm{g}$ dry weight selenium.

\section{Selenlum In aquatic invertebrates}

A total of 29 crayfish, 3 snail, 1 earthworm, and 21 other aquatic-invertebrate (aquatic insects) samples were collected within the Dolores Project study area (table 27). After combining all invertebrate species, and excluding reference sites upstream from the irrigated areas (sites ME1, SD, and CR), geometric mean selenium concentrations were calculated for invertebrates from the MVIC and Dove Creek areas, the Mancos and San Juan Rivers, and reservoirs within the Dolores Project area (table 19, fig. 10). For MVIC streams, the geometric mean selenium concentration for 23 aquatic-invertebrate samples was $1.7 \mu \mathrm{g} / \mathrm{g}$ dry weight. The geometric mean selenium concentration for 5 aquatic-invertebrate samples (excluding the earthworm sample from site ME1) from MVIC reference sites (sites ME1 and SD) was 1.8 (standard deviation 1.6). Thus, there was no apparent difference in geometric mean selenium concentrations in aquatic invertebrates between the irrigated and the non-irrigated MVIC areas.

Of the aquatic-invertebrate samples from the MVIC area, the five samples collected from Navajo Wash (site NW) contained from 3.3 to $9.3 \mu \mathrm{g} / \mathrm{g}$ dry weight selenium (table 27), and these concentrations

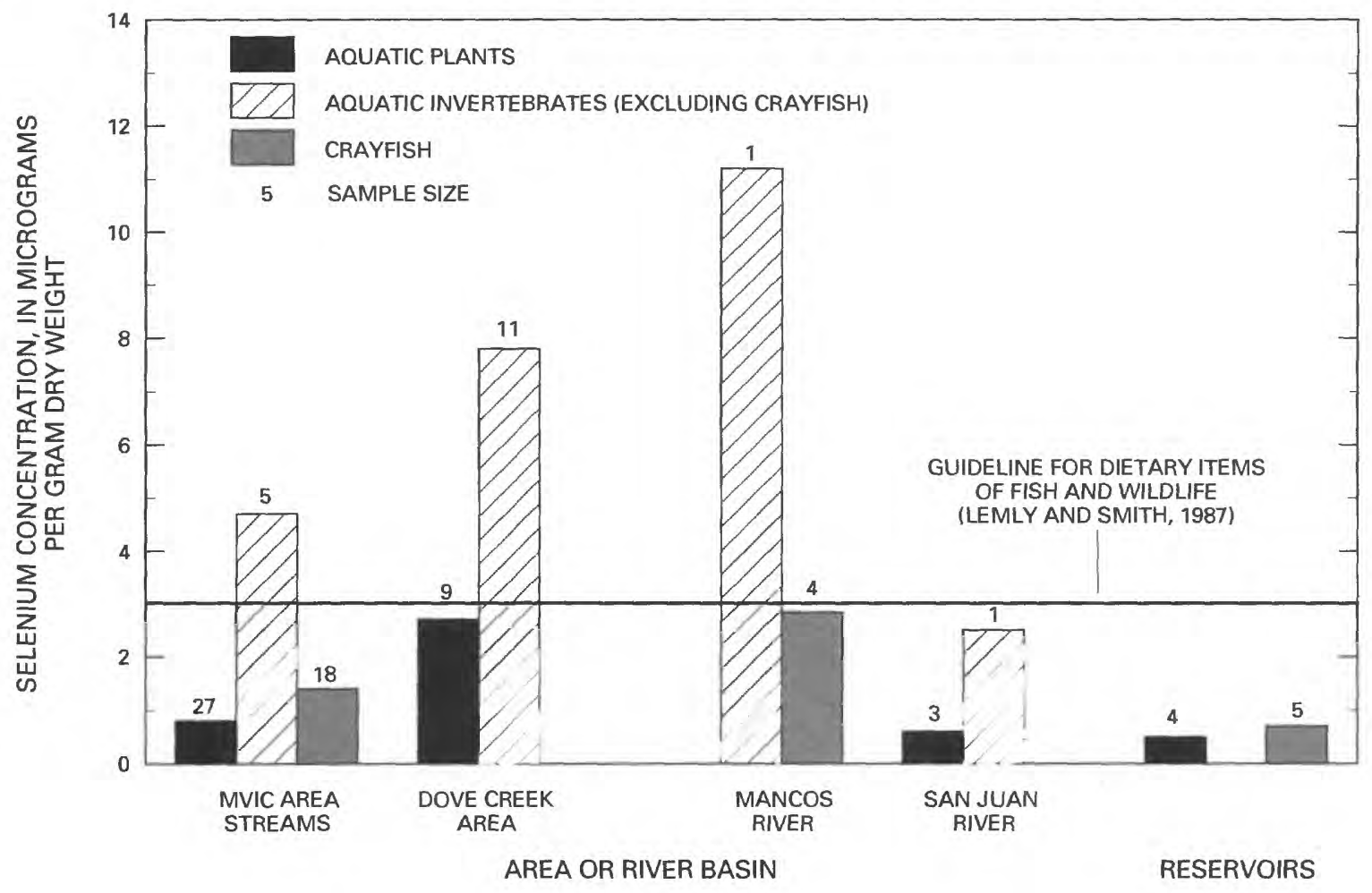

Figure 10. Geometric mean selenium concentrations in dietary items of fish and wildife. (No bar indicates no data. MVIC, Montezuma Valley Irrigation Company. Means for MVIC and Dove Creek areas do not include data from reference sites.) 
exceed the dietary guideline concentration of $3 \mu \mathrm{g} / \mathrm{g}$ dry weight selenium for protection of fish and wildlife resources (Lemly and Smith, 1987; Lemly, 1993). One aquatic-invertebrate sample collected from lower Yellow Jacket Canyon (site YJ2) contained $3.1 \mu \mathrm{g} / \mathrm{g}$ dry weight selenium (table 27). A crayfish sample from Mc Elmo Creek (site ME3), contained $3.7 \mu \mathrm{g} / \mathrm{g}$ dry weight selenium. An earthworm sample collected from the water at site ME1 on Mc Elmo Creek (fig. 1) contained $21 \mu \mathrm{g} / \mathrm{g}$ dry weight selenium (table 27).

Although earthworms are not typically considered aquatic invertebrates, they are a potential food source for fish and birds. The selenium concentration exceeded the dietary guideline of $3 \mu \mathrm{g} / \mathrm{g}$ dry weight selenium (Lemly and Smith, 1987; Lemly, 1993) by seven times. Another aquatic-invertebrate sample collected at site ME1 contained $3.4 \mu \mathrm{g} / \mathrm{g}$ dry weight selenium (table 27). It is noteworthy that surface-water samples collected from Navajo Wash and Mc Elmo Creek also contained the highest selenium concentrations of the sampled drainages within the MVIC area (table 22, fig. 8).

The geometric mean selenium concentration for aquatic-invertebrate samples from the Dove Creek area (excluding the reference site CR) was $7.8 \mu \mathrm{g} / \mathrm{g}$ dry weight (table 19, fig. 10). Ten of the 11 aquaticinvertebrate samples collected from the Dove Creek area exceeded the dietary guideline concentration of $3 \mu \mathrm{g} / \mathrm{g}$ dry weight selenium (table 27). Aquatic invertebrates from upper Yellow Jacket Canyon (site YJ1) contained 10 and $15.7 \mu \mathrm{g} / \mathrm{g}$ dry weight selenium (table 27). Aquatic invertebrates from Cahone Canyon (site $\mathrm{CH}$ ) contained $7.4,11.2$, and $6.7 \mu \mathrm{g} / \mathrm{g}$ dry weight selenium. All aquatic-invertebrate samples from the pond at Woods Canyon (site WC) contained relatively high selenium concentrations of $9.6,13.4$, and $19.2 \mu \mathrm{g} / \mathrm{g}$ dry weight selenium (table 27). Also, two of the three snail samples collected from site WC exceeded the dietary guideline of $3 \mu \mathrm{g} / \mathrm{g}$ dry weight selenium, containing 3.7 and $3.9 \mu \mathrm{g} / \mathrm{g}$ dry weight selenium. The geometric mean selenium concentration for three aquatic-invertebrate samples from the Dove Creek area reference site upstream from irrigation (site CR) was $4.1 \mu \mathrm{g} / \mathrm{g}$ dry weight (standard deviation 1.7), and was lower than the mean calculated for invertebrates collected from the irrigated area $(7.8 \mu \mathrm{g} / \mathrm{g}$ dry weight). Two aquatic-invertebrate samples from reference site CR contained 5.0 and $6.1 \mu \mathrm{g} / \mathrm{g}$ dry weight selenium. As with aquatic-plant samples, aquaticinvertebrate samples collected from the Dove Creek area had higher selenium concentrations than the MVIC area (table 19, fig. 10).
The geometric mean selenium concentration for five aquatic-invertebrate samples collected from the Mancos River was $3.7 \mu \mathrm{g} / \mathrm{g}$ dry weight (table 19), and two samples exceeded the $3 \mu \mathrm{g} / \mathrm{g}$ dry weight selenium dietary guideline (Lemly, 1993) at concentrations of 6.7 and $11.2 \mu \mathrm{g} / \mathrm{g}$ dry weight (table 27). The aquaticinvertebrate sample collected from the San Juan River (site SJ1) contained $2.5 \mu \mathrm{g} / \mathrm{g}$ dry weight selenium (tables 19 and 27).

The geometric mean selenium concentration for the five crayfish samples collected from the reservoirs was $0.66 \mu \mathrm{g} / \mathrm{g}$ dry weight (table 19, fig. 10), and was lower than the geometric mean concentration for crayfish collected from MVIC streams. Eight zooplankton samples collected in the reservoirs contained from 0.4 to $2.9 \mu \mathrm{g} / \mathrm{g}$ selenium dry weight, less than the $3 \mu \mathrm{g} / \mathrm{g}$ dry weight selenium dietary guideline concentration.

\section{Selenium in fish}

Seventy-eight suckers were collected within the Dolores Project area. Geometric mean selenium concentrations in whole-body sucker samples are compared in table 19 and figure 11. The geometric mean selenium concentration for 44 suckers collected from MVIC streams (excluding two reference site samples) was only $1.5 \mu \mathrm{g} / \mathrm{g}$ dry weight. The geometric mean selenium concentration for two bluehead sucker samples collected from Simon Draw (site SD), a MVIC ref-

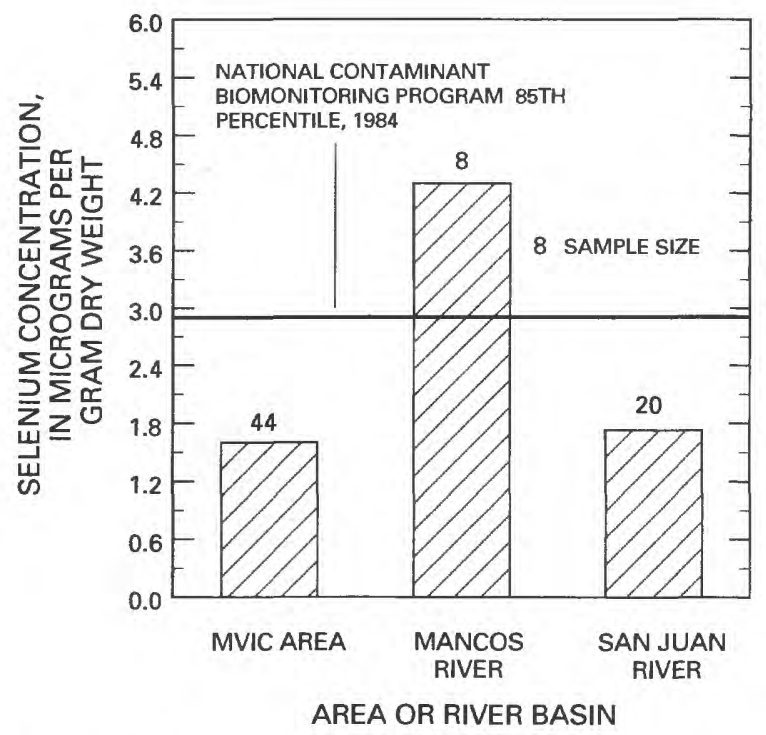

Figure 11. Geometric mean selenium concentrations in whole-body sucker samples collected from streams. (MVIC, Montezuma Valley Irrigation Company.) 
erence site upstream from irrigation, was $1.6 \mu \mathrm{g} / \mathrm{g}$ dry weight (standard deviation 1.1), comparable to the mean for fish collected from the irrigated MVIC area. Only 4 of the 46 sucker samples from the MVIC area contained selenium concentrations that exceeded the 1984 NCBP 85th-percentile concentration of $0.73 \mu \mathrm{g} / \mathrm{g}$ wet weight (Schmitt and Brumbaugh, 1990) (tables 18 and 27). Geometric mean selenium concentrations in whole-body sucker samples collected from the different MVIC streams are compared in figure 12. One sucker sample collected from site ME3 contained $3.6 \mu \mathrm{g} / \mathrm{g}$ dry weight selenium $(0.81 \mu \mathrm{g} / \mathrm{g}$ wet weight $)$, and another sucker sample collected from site ME4 contained $3.0 \mu \mathrm{g} / \mathrm{g}$ dry weight selenium $(0.78 \mu \mathrm{g} / \mathrm{g}$ wet weight) (table 27). Both sucker samples collected from site NW contained relatively high selenium concentrations of $7.2 \mu \mathrm{g} / \mathrm{g}$ dry weight selenium $(1.5 \mu \mathrm{g} / \mathrm{g}$ wet weight) and $9.3 \mu \mathrm{g} / \mathrm{g}$ dry weight ( $1.6 \mu \mathrm{g} / \mathrm{g}$ wet weight). These concentrations not only exceed the 1984 NCBP 85 th percentile, but also exceed the concentration of $4 \mu \mathrm{g} / \mathrm{g}$ dry weight selenium concentration that Lemly (1993) recommended to be a whole-body concentration of concern for the overall health and reproductive vigor of freshwater fish. The pattern of selenium concentrations in sucker samples from MVIC drainages correlates well with the pattern of selenium concentrations in surface water samples from the same drainages (figs. 8 and 12).

The geometric mean selenium concentration for four sucker samples collected from the reservoirs was $1.3 \mu \mathrm{g} / \mathrm{g}$ dry weight selenium. This mean selenium concentration is similar to the mean concentration for suckers collected from MVIC streams (fig. 11).

Seven of the eight sucker samples collected from the Mancos River exceeded the 1984 NCBP 85th percentile (Schmitt and Brumbaugh, 1990) (tables 18 and 27 ), and four of these samples exceeded the $4 \mu \mathrm{g} / \mathrm{g}$ dry weight selenium concentration of concern (Lemly, 1993). The four samples contained $6.5,4.8,7.6$, and $7.6 \mu \mathrm{g} / \mathrm{g}$ dry weight selenium (table 27).

Selenium concentrations in the 20 sucker samples collected from the San Juan River were lower than those collected from the Mancos River (fig. 11, table 19). The mean selenium concentration for suckers collected at site SJ1 was $1.62 \mu \mathrm{g} / \mathrm{g}$ dry weight selenium (standard deviation 1.14) and for site SJ3 was

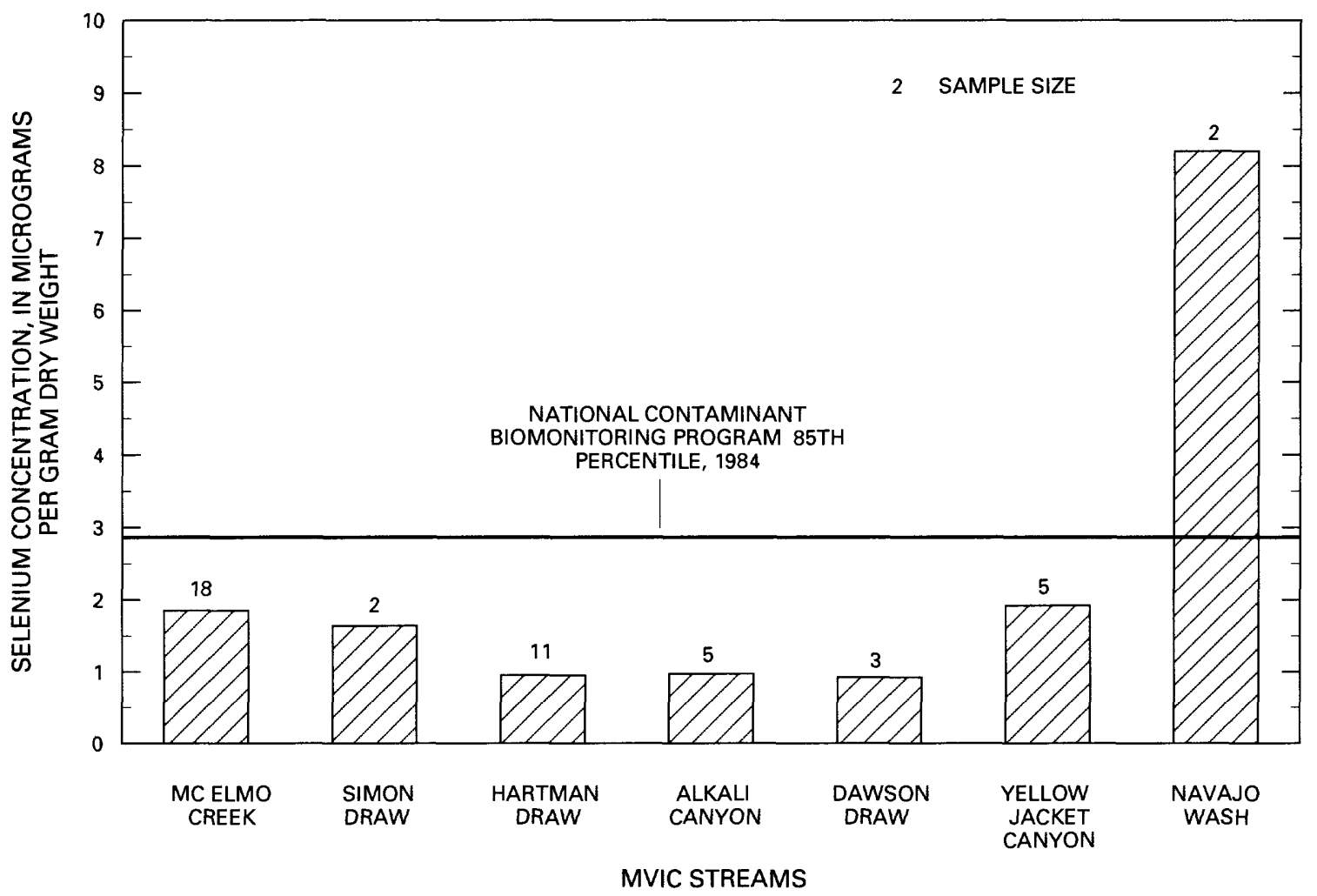

Figure 12. Geometric mean selenium concentrations in whole-body sucker samples collected from streams draining the MVIC (Montezuma Valley Irrigation Company) area. 
$2.23 \mu \mathrm{g} / \mathrm{g}$ dry weight selenium (standard deviation 0.59). Based on a Mann-Whitney U-test (Iman and Conover, 1983), suckers from site SJ3 had significantly higher selenium concentrations $(p=0.034)$ than those collected from site SJ1 (table 27). Apparently, suckers at site $\mathrm{SJ} 3$ accumulated more selenium than suckers at site $S J 1$, although selenium concentrations in surfacewater samples were not different between the two sites (fig. 9, table 22). However, accumulation of selenium through the food chain usually is the major pathway of uptake for fish and wildlife species of higher trophic levels, rather than uptake directly from the water (Lemly 1985; 1993).

One sucker sample collected from site SJ1 contained $4.2 \mu \mathrm{g} / \mathrm{g}$ dry weight selenium $(0.92 \mu \mathrm{g} / \mathrm{g}$ wet weight) (table 27), which exceeds the 1984 NCBP 85th-percentile concentration (Schmitt and Brumbaugh, 1990) and the $4 \mu \mathrm{g} / \mathrm{g}$ dry weight selenium concentration of concern for whole-body fish (Lemly, 1993). Selenium concentrations in two sucker samples from site SJ3 exceeded the 1984 NCBP 85th percentile (Schmitt and Brumbaugh, 1990).

Twelve carp samples were collected within the Dolores Project area (table 27). Five carp from Mc Elmo Creek (collected at sites ME3 and ME4) had a geometric mean selenium concentration of $4.2 \mu \mathrm{g} / \mathrm{g}$ dry weight, three carp from the Mancos River had a geometric mean selenium concentration of $6.8 \mu \mathrm{g} / \mathrm{g}$ dry weight, and four carp from the San Juan River had a geometric mean selenium concentration of $2.8 \mu \mathrm{g} / \mathrm{g}$ dry weight (table 19). Eleven of the twelve carp samples contained selenium concentrations that exceeded the 1984 NCBP 85th-percentile (Schmitt and Brumbaugh, 1990) (table 27), and six of these carp samples also exceeded the $4 \mu \mathrm{g} / \mathrm{g}$ dry weight selenium concentration of concern in whole-body fish (Lemly,1993).

Twenty-eight fathead minnow samples were collected within the Dolores Project area (table 27). The geometric mean selenium concentration for 19 fathead minnow samples collected from the MVIC area streams (excluding reference sites ME1 and SD) was $3.4 \mu \mathrm{g} / \mathrm{g}$ dry weight (table 19). The geometric mean selenium concentration for 4 fathead minnow samples collected from MVIC reference sites (sites ME1 and SD) was $4.3 \mu \mathrm{g} / \mathrm{g}$ dry weight (standard deviation 1.3), which is comparable to selenium concentrations in fathead minnows collected within the irrigated MVIC area. Fifteen of the 23 fathead minnow samples from the MVIC area had selenium concentrations that exceeded the 1984 NCBP 85th percentile (Schmitt and Brumbaugh, 1990) (table 27), and 10 of these samples equaled or exceeded the $4 \mu \mathrm{g} / \mathrm{g}$ dry weight selenium concentration of concern in whole-body fish (Lemly,
1993). Of the streams in the MVIC area, Mc Elmo Creek (sites ME1-ME4) and lower Yellow Jacket Canyon (site YJ2) had the highest selenium concentrations in fathead minnows.

Researchers commonly use fathead minnows in laboratory toxicity studies. Ogle and Knight (1989) reported that a whole-body selenium concentration of $6 \mu \mathrm{g} / \mathrm{g}$ dry weight slowed the growth in juvenile and adult fathead minnows. Schultz and Hermanutz (1990) reported reproductive failure at a whole-body selenium concentration of $8 \mu \mathrm{g} / \mathrm{g}$ dry weight. One fathead minnow sample collected from site YJ2 contained $11 \mu \mathrm{g} / \mathrm{g}$ dry weight selenium (table 27), which exceeded known toxicity concentrations to fathead minnows.

Selenium concentrations in three fathead minnow samples collected from the pond in Woods Canyon (site WC) in the Dove Creek area ranged from 18.4 to $26.4 \mu \mathrm{g} / \mathrm{g}$ dry weight, with a geometric mean selenium concentration of $22.3 \mu \mathrm{g} / \mathrm{g}$ dry weight (tables 19 and 27). The selenium concentrations in these samples greatly exceeded those associated with toxic effects for fathead minnows (Ogle and Knight, 1989; Schultz and Hermanutz 1990). As was the case with aquatic-plant and aquatic-invertebrate samples, selenium concentrations were considerably higher in fathead minnows collected from the Dove Creek area compared to those from the MVIC area. Selenium concentrations also were relatively high in the fathead minnow samples collected in the Mancos River, at concentrations of 7.7 and $14 \mu \mathrm{g} / \mathrm{g}$ dry weight (table 27).

Of the 18 speckled dace samples collected within the MVIC area (including the sample from site ME1), 17 contained selenium concentrations that exceeded the 1984 NCBP 85th-percentile (Schmitt and Brumbaugh, 1990), and 14 equaled or exceeded the $4 \mu \mathrm{g} / \mathrm{g}$ dry weight selenium concentration of concern (Lemly, 1993). As with other biota, the highest selenium concentration in a speckled dace sample from the MVIC area was collected from Navajo Wash at site NW (concentration $8.7 \mu \mathrm{g} / \mathrm{g}$ dry weight; table 27 ). The geometric mean selenium concentration for 17 speckled dace samples collected within the MVIC service area was $4.9 \mu \mathrm{g} / \mathrm{g}$ dry weight (table 19). The only speckled dace sample collected from a MVIC area reference site was from Mc Elmo Creek at site ME1, and that sample had $6.4 \mu \mathrm{g} / \mathrm{g}$ dry weight selenium. One speckled dace sample collected in the Mancos River contained $5.5 \mu \mathrm{g} / \mathrm{g}$ dry weight selenium, and three speckled dace samples collected from the San Juan River had a geometric mean selenium concentration of $4.0 \mu \mathrm{g} / \mathrm{g}$ dry weight (table 19 and 27 ), and individual samples exceeding the concentration of concern. 
A few piscivorous fish were collected from streams and rivers within the Dolores Project area. Four samples were collected from streams in the MVIC area. A bullhead sample containing $3.0 \mu \mathrm{g} / \mathrm{g}$ dry weight selenium and a green sunfish sample containing $5.0 \mu \mathrm{g} / \mathrm{g}$ dry weight selenium were collected at site ME3. Two samples of green sunfish were collected at site HD1, and each contained $1.3 \mu \mathrm{g} / \mathrm{g}$ dry weight selenium (table 27). The selenium concentration of $5.0 \mu \mathrm{g} / \mathrm{g}$ dry weight exceeds the $4 \mu \mathrm{g} / \mathrm{g}$ dry weight concentration of concern (Lemly, 1993), but is less than the $12 \mu \mathrm{g} / \mathrm{g}$ dry weight concentration that Lemly and Smith (1987) associated with reproductive failure in warmwater fishes. Members of the sunfish family are especially sensitive to selenium (Cumbie and Van Horn, 1978; Lemly, 1985; 1993).

A roundtail chub sample collected from the Mancos River at site MN2 contained $5.4 \mu \mathrm{g} / \mathrm{g}$ dry weight selenium (table 27), exceeding the $4 \mu \mathrm{g} / \mathrm{g}$ dry weight concentration of concern for whole-body fish (Lemly, 1993). Three of four whole-body channel catfish samples collected from three sites on the San Juan River contained selenium concentrations (table 27) exceeding the concentration of concern. A fillet sample containing $2.2 \mu \mathrm{g} / \mathrm{g}$ dry weight selenium and a channel catfish-liver sample containing $5.8 \mu \mathrm{g} / \mathrm{g}$ dry weight selenium were collected at site SJ1. These concentrations are less than the concentrations of concern for fish health-12 $12 \mathrm{~g} / \mathrm{g}$ dry weight selenium in the liver and $8 \mu \mathrm{g} / \mathrm{g}$ dry weight selenium in fillets (Lemly, 1993).

Selenium concentrations in piscivorous fish samples collected from McPhee, Summit, Puett, and Totten Reservoirs contained relatively low selenium concentrations compared to stream sites. The selenium concentration of $4.2 \mu \mathrm{g} / \mathrm{g}$ dry weight $(1.0 \mu \mathrm{g} / \mathrm{g}$ wet weight) in a whole-body roundtail chub sample from McPhee Reservoir (site MP) (table 27) was the only selenium concentration in a piscivorous fish from reservoirs that exceeded the 1984 NCBP 85th percentile (Schmitt and Brumbaugh, 1990) and also exceeded the $4 \mu \mathrm{g} / \mathrm{g}$ dry weight selenium concentration of concern for whole-body fish. All selenium concentrations in fillet and in fish egg samples were less than selenium concentrations of concern of $8 \mu \mathrm{g} / \mathrm{g}$ dry weight for fillets and $10 \mu \mathrm{g} / \mathrm{g}$ dry weight for eggs (Lemly, 1993).

\section{Selenlum in birds}

Thirty bird samples were collected within the Dolores Project area (table 27); of these, 15 were eggs, 9 were livers, and 6 were whole-body samples. Three of the five collection sites are within the MVIC area;
Dawson Draw (site DD), Leighton Pond (site LP), and Totten Reservoir (site TT) (fig. 1). Two collection sites are located within the Dove Creek area, at a pond (site AKP) in the Alkali Canyon drainage, a tributary to Cross Canyon, and the pond in Woods Canyon (site WC). Geometric mean selenium concentrations were calculated for all of the bird-liver and egg samples collected in the entire Dolores Project area. The geometric mean selenium concentration was $3.6 \mu \mathrm{g} / \mathrm{g}$ dry weight (standard deviation 2.0) for egg samples and $6.0 \mu \mathrm{g} / \mathrm{g}$ dry weight (standard deviation 2.4) for liver samples. J.P. Skorupa (U.S. Fish and Wildlife Service, written commun., 1993) reported that baseline geometric mean selenium concentrations rarely exceeded $3 \mu \mathrm{g} / \mathrm{g}$ dry weight selenium in eggs and $10 \mu \mathrm{g} / \mathrm{g}$ dry weight selenium in livers, and warned that there is a high risk of adverse biological effects when population mean selenium concentrations exceed $20 \mu \mathrm{g} / \mathrm{g}$ dry weight in eggs and $30 \mu \mathrm{g} / \mathrm{g}$ dry weight in livers. Skorupa also suggested that if population geometric means were between 3 and $20 \mu \mathrm{g} / \mathrm{g}$ dry weight selenium in eggs and between 10 and $30 \mu \mathrm{g} / \mathrm{g}$ dry weight selenium in livers, associated studies of reproductive performance would be needed for conclusive interpretation of biological significance. The mean selenium concentration of $3.6 \mu \mathrm{g} / \mathrm{g}$ dry weight for bird eggs collected from the Dolores Project area is within the range of uncertainty for bird eggs. The mean selenium concentration of $6.0 \mu \mathrm{g} / \mathrm{g}$ dry weight for bird livers from the Dolores Project area is less than the baseline selenium concentration of $10 \mu \mathrm{g} / \mathrm{g}$ dry weight (J.P. Skorupa, U.S. Fish and Wildlife Service, written commun., 1993). The highest selenium concentration detected in bird-tissue samples was in a mallard liver collected in Woods Canyon (table 27), which contained $37.5 \mu \mathrm{g} / \mathrm{g}$ dry weight selenium $(10.5 \mu \mathrm{g} / \mathrm{g}$ wet weight), and a coot egg sample collected from the pond in Alkali Canyon (site AKP), which contained $18.5 \mu \mathrm{g} / \mathrm{g}$ dry weight selenium $(4.5 \mu \mathrm{g} / \mathrm{g}$ wet weight). Gary Heinz (U.S. Fish and Wildlife Service, written commun., 1993) and Lemly (1993) suggested that selenium concentrations exceeding $10 \mu \mathrm{g} / \mathrm{g}$ wet weight in bird livers are potentially harmful to bird health and that concentrations greater than $3 \mu \mathrm{g} / \mathrm{g}$ wet weight in livers of laying females may be associated with reproductive impairment. No deformities were found in the field, upon examination of egg contents, or in the collected birds. All food items (aquatic invertebrates and aquatic plants) collected at the five bird-sampling sites had selenium concentrations less than the dietary concentration of concern of $3 \mu \mathrm{g} / \mathrm{g}$ dry weight (Lemly and Smith, 1987; Lemly, 1993), except for Woods Canyon 
(site WC), which had high selenium concentrations in food items and in bird-tissue samples.

In summary, selenium concentrations in biota collected from the Dove Creek area often exceeded selenium concentrations in biota collected from the MVIC area. As discussed previously in the report, the long-term irrigation and high application rates in the northern MVIC area may have leached most of the soluble selenium from the red soil areas, but in the Dove Creek area, the soluble selenium may not be leached from the soil because the area had been irrigated less than 3 years. Within the MVIC area, biota samples containing the highest selenium concentrations often were from Navajo Wash. Navajo Wash drains irrigated areas on gray, seleniferous (Mancos) soils south of Cortez, which could account for the higher selenium concentrations in water, sediment, and biota samples. Streams north of Mc Elmo Creek drain irrigated areas on mixed red and gray soils or on red soils. Selenium concentrations in biota (crayfish and fish) collected from reservoirs usually were much lower than in biota collected from streams.

Biota samples collected from the Mancos River generally had relatively high selenium concentrations, especially when compared to biota samples collected from the San Juan River. That result was not surprising because the Mancos River drains extensive areas of Mancos Shale. Higher streamflow in the San Juan River dilutes incoming selenium from tributary streams. However, fish collected from the San Juan River often contained selenium concentrations that exceeded the concentration of concern of $4 \mu \mathrm{g} / \mathrm{g}$ dry weight. Selenium concentrations in suckers collected from the San Juan River at site SJ3 had significantly higher selenium concentrations than in suckers collected from site $S J 1$. Additional studies would be needed to assess the potential effects of irrigation drainage from the Dolores Project to endangered fish species in the San Juan River. Young-of-year Colorado squawfish were found near the confluence of the San Juan River and the Mancos River. Selenium concentrations are relatively high in the Mancos River. Juvenile fish often are quite susceptible to selenium toxicity (Hodson and others, 1980; Hunn and others, 1987; Hamilton and others, 1990), therefore, there is a potential risk to these endangered fish. The amount of selenium in the Mancos River contributed by irrigation drainage has not been fully investigated.

\section{Mercury}

Mercury concentrations that exceeded analytical reporting limits in aquatic plants collected within the Dolores Project area ranged from 0.01 to $0.08 \mu \mathrm{g} / \mathrm{g}$ dry weight (table 27), except for one algal sample from site HD1 that contained $0.26 \mu \mathrm{g} / \mathrm{g}$ dry weight mercury ( 0.03 wet weight). There seemed to be no differences among sites in mercury concentrations in aquatic plants in the Dolores Project area. All mercury concentrations in aquatic-plant samples were less than $0.1 \mu \mathrm{g} / \mathrm{g}$ wet weight, which is a dietary guideline not to be exceeded for the protection of sensitive species of birds (Eisler, 1987a).

The geometric mean mercury concentration for 20 crayfish samples collected from streams in the MVIC area was $0.09 \mu \mathrm{g} / \mathrm{g}$ dry weight (geometric deviation 1.52) and was slightly lower than the geometric mean mercury concentration in 5 crayfish samples collected from the reservoirs of $0.12 \mu \mathrm{g} / \mathrm{g}$ dry weight (standard deviation 0.10). The geometric mean mercury concentration in eight non-crayfish aquaticinvertebrate samples from the MVIC area (excluding the earthworm collected at site ME1) was $0.15 \mu \mathrm{g} / \mathrm{L}$ dry weight (geometric deviation 1.51), which is about 1.7 times greater than the geometric mean mercury concentration in crayfish samples. The geometric mean mercury concentration is $0.06 \mu \mathrm{g} / \mathrm{g}$ dry weight (geometric deviation 2.13) for the 11 aquaticinvertebrate samples (other than crayfish) collected from the Dove Creek area. An invertebrate sample collected from the Mancos River at site MN1 (fig. 1) contained $0.84 \mu \mathrm{g} / \mathrm{g}$ dry weight mercury $(0.12 \mu \mathrm{g} / \mathrm{g}$ wet weight) (table 27), and was the only mercury concentration that exceeded the dietary guideline concentration of $0.1 \mu \mathrm{g} / \mathrm{g}$ wet weight for the protection of birds (Eisler, 1987a). Hildebrand and others (1980) suggested that invertebrates with mercury concentrations of $0.05 \mu \mathrm{g} / \mathrm{g}$ wet weight or less are indicative of uncontaminated environments and that concentrations equal to or greater than 1 to $4 \mu \mathrm{g} / \mathrm{g}$ wet weight are indicative of contaminated environments. All mercury concentrations in aquatic-invertebrate samples from the Dolores Project area were much less than $1 \mu \mathrm{g} / \mathrm{g}$ wet weight. Zooplankton samples collected from four MVIC area reservoirs (sites MP, SU, PU, and TT) also contained low mercury concentrations that ranged from 0.05 to $0.37 \mu \mathrm{g} / \mathrm{g}$ dry weight (less than $0.008 \mu \mathrm{g} / \mathrm{g}$ wet weight) (table 27).

Twenty-nine of the 181 whole-body fish samples collected in the Dolores Project area contained mercury concentrations greater than the 1984 NCBP 85 th-percentile concentration of $0.17 \mu \mathrm{g} / \mathrm{g}$ wet weight $(0.65 \mu \mathrm{g} / \mathrm{g}$ dry weight at 75 -percent moisture) (Schmitt and Brumbaugh, 1990) (table 18). Seventeen of those 29 samples were collected from McPhee, Summit, Puett, and Totten Reservoirs, 11 were collected from streams in the MVIC area (sites ME3, ME4, HD2, AK, 
$\mathrm{DD}$, and YJ2), and one sample was collected from the Mancos River. Eisler (1987a) recommended that total mercury concentrations in food items for sensitive species of birds not exceed $0.1 \mu \mathrm{g} / \mathrm{g}$ wet weight; mercury concentrations in the 73 fish samples exceeded that guideline. However, the mercury concentrations in all whole-body fish samples were much less than the whole-body concentration of $5 \mu \mathrm{g} / \mathrm{g}$ wet weight mercury proposed by the U.S. Environmental Protection Agency (1985) for the protection of brook trout (one of the species most sensitive to mercury).

The highest mercury concentrations in fish were in warm-water game species, especially walleye, smallmouth bass, and northern pike collected from the four reservoirs in or adjacent to the MVIC area (fig. 13). Mercury accumulation in fish is thought to be facilitated by reservoirs where conditions are conducive to methylation of mercury, which increases mercury uptake by biota (Bodaly and others, 1984; Phillips and others, 1987; Stokes and Wren, 1987). Other researchers have found that mercury accumulation increases with fish length (age) and also seems to vary from species to species (Eisler, 1987a; Phillips and others, 1987; Wiener and others, 1990).

An action level of $1 \mu \mathrm{g} / \mathrm{g}$ wet weight was suggested by the U.S. Food and Drug Administration (1978) as the maximum allowable mercury concentra- tion in fish and seafood to be consumed by humans. The National Research Council (1978) suggested that humans in the United States should not consume fish that had mercury concentrations greater than $0.5 \mu \mathrm{g} / \mathrm{g}$ wet weight. Eleven fillet and whole-body fish samples had mercury concentrations that exceeded $0.5 \mu \mathrm{g} / \mathrm{g}$ wet weight mercury, and all the samples were collected from reservoirs. Kahn (1971) recommended that pregnant women should not consume fish or seafood having more than $0.25 \mu \mathrm{g} / \mathrm{g}$ wet weight mercury. Twenty two of the 23 fillet and whole-body fish samples that had mercury concentrations exceeding $0.25 \mu \mathrm{g} / \mathrm{g}$ wet weight were collected from the reservoirs. McPhee and Narraguinnep Reservoirs were posted in May 1991 advising anglers of elevated mercury concentrations in fish and suggesting limits for human consumption (Colorado Department of Health, 1992).

Recommended weekly maximum amounts of fish that could safely be consumed by an adult, a child under the age of 9, and a pregnant woman, as prescribed by the Colorado Department of Health, are listed in table 20. The risk assessment used for the calculation of weekly consumption rates in table 20 is based on the U.S. Environmental Protection Agency's reference dose of $0.3 \mu \mathrm{g} / \mathrm{kg} / \mathrm{d}$ for adults and children based on a lifetime daily dose at which no adverse

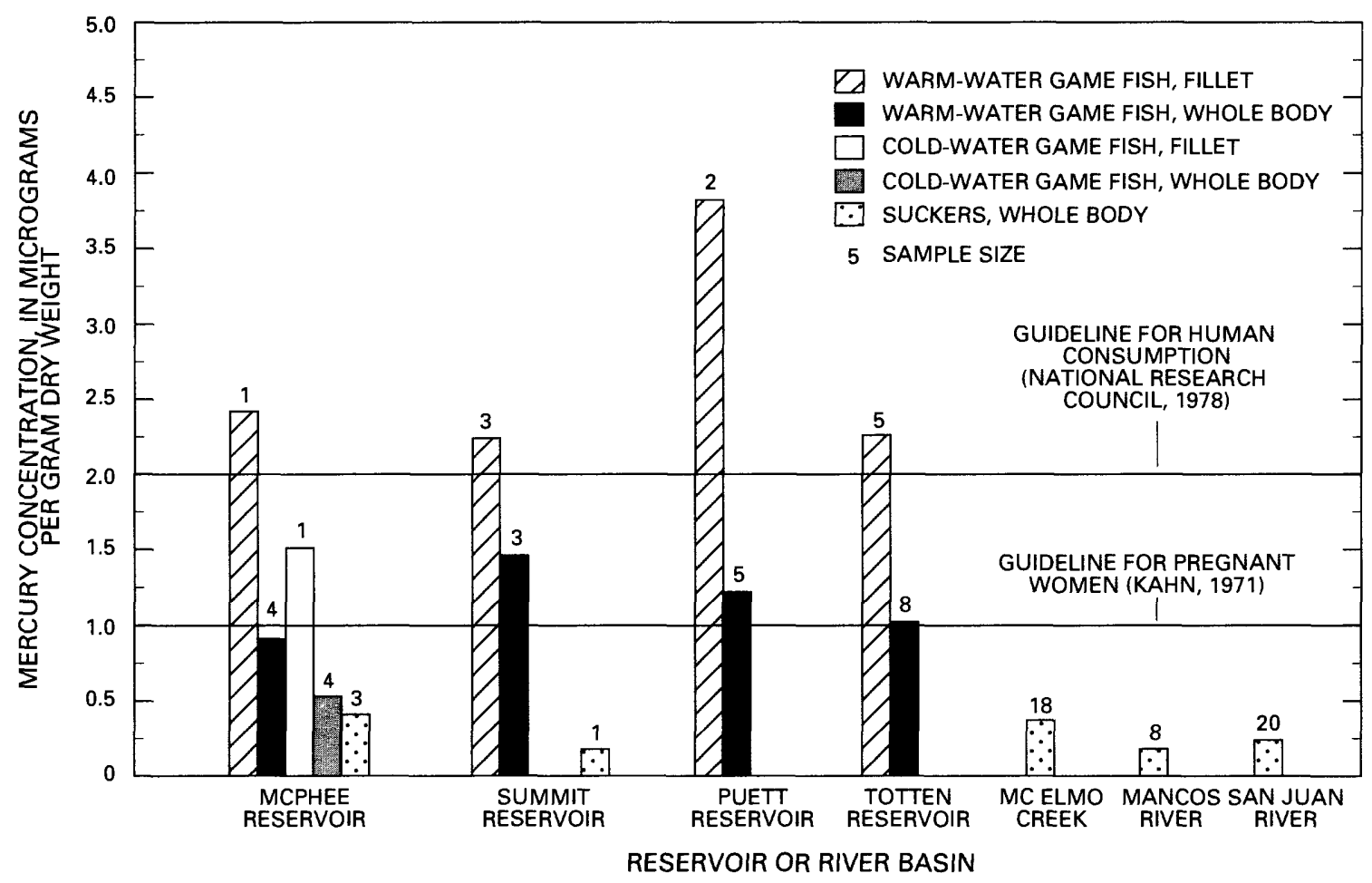

Figure 13. Geometric mean mercury concentrations in fillet and whole-body fish samples. Warm-water game fish included northern pike, walleye, bluegill, black crappie, smallmouth bass, largemouth bass, and yellow perch. Cold-water game fish included rainbow trout and kokanee salmon. (No bar indicates no data. Consumption guidelines computed from wet-weight concentrations using 75 percent moisture.) 
Table 20. Mean mercury concentrations in fillets of game fish collected in the Dolores Project area, 1988-91, and recommended human consumption limits

[Fish samples collected and analyzed by U.S. Fish and Wildlife Service, Bureau of Reclamation, and Colorado Division of Wildlife (Michael Japhet, Colorado Division of Wildlife, written commun., 1992); mean concentrations in micrograms per gram wet weight; NS, number of samples; NF, total number of fish composited in samples; consumption limits based on a reference dose of 0.3 microgram mercury per kilogram body weight per day for adults and children and 0.075 microgram mercury per kilogram body weight per day for women who are pregnant, nursing, or planning to become pregnant (Michael P. Wilson, Colorado Department of Health, written commun., 1992)]

\begin{tabular}{|c|c|c|c|c|c|c|c|}
\hline \multirow[b]{2}{*}{ Site } & \multirow[b]{2}{*}{ Species } & \multirow[b]{2}{*}{ NS } & \multirow[b]{2}{*}{ NF } & \multirow[b]{2}{*}{ Mean } & \multicolumn{3}{|c|}{$\begin{array}{l}\text { Recommended consumption limit, } \\
\text { in ounces per week }\end{array}$} \\
\hline & & & & & $\begin{array}{c}\text { 70-kilogram } \\
\text { aduit }\end{array}$ & $\begin{array}{c}\text { 18-kllogram } \\
\text { child }^{1}\end{array}$ & $\begin{array}{c}\text { 60-kilogram } \\
\text { pregnant } \\
\text { woman }\end{array}$ \\
\hline Dolores River & Brown trout & 1 & 6 & 0.31 & 17 & 4 & 4 \\
\hline \multirow[t]{6}{*}{ McPhee Reservoir } & Kokanee salmon & 2 & 13 & .09 & 58 & 15 & 12 \\
\hline & Rainbow trout & 4 & 18 & .24 & 22 & 6 & 5 \\
\hline & Yellow perch & 2 & 18 & .21 & 25 & 6 & 5 \\
\hline & Smallmouth bass & 2 & 10 & .29 & 18 & 5 & 4 \\
\hline & Largemouth bass & 3 & 10 & .61 & 8 & 2 & 2 \\
\hline & Black crappie & 1 & 9 & .53 & 10 & 3 & 2 \\
\hline \multirow[t]{4}{*}{ Narraguinnep Reservoir } & Yellow perch & 2 & 14 & .22 & 24 & 6 & 5 \\
\hline & Channel catfish & 1 & 9 & .43 & 12 & 3 & 3 \\
\hline & Northern pike & 5 & 11 & .70 & 7 & 2 & 2 \\
\hline & Walleye & 4 & 27 & 1.11 & 0 & 0 & 0 \\
\hline \multirow[t]{2}{*}{ Summit Reservoir } & Smallmouth bass & 3 & 6 & .50 & 10 & 3 & 2 \\
\hline & Black crappie & 1 & 3 & .33 & 16 & 4 & 3 \\
\hline Puett Reservoir & Walleye & 2 & 3 & .87 & 6 & 2 & 1 \\
\hline \multirow[t]{2}{*}{ Totten Reservoir } & Northern pike & 2 & 2 & .38 & 14 & 3 & 3 \\
\hline & Walleye & 3 & 3 & .69 & 7 & 2 & 2 \\
\hline
\end{tabular}

\footnotetext{
planning to become pregnant may wish to limit their consumption to fish with mercury concentrations less than this level.
}

health effects are expected to occur (Colorado Department of Health, written commun., 1992). The amount of fish that can safely be consumed varied by species of fish and the site from which the fish were taken (table 20). The quantity of fish that can safely be consumed by a 70-kg adult in a week ranged from $58 \mathrm{oz}$ of kokanee salmon from McPhee Reservoir to $0 \mathrm{oz}$ of walleye from Narriguinnep Reservoir (table 20).

There was a large range of mercury concentrations in bird tissues collected from the Dolores Project area. The highest mercury concentrations were $1.53 \mu \mathrm{g} / \mathrm{g}$ dry weight $(0.50 \mu \mathrm{g} / \mathrm{g}$ wet weight $)$ in a whole-body yellowhead blackbird sample from Totten Reservoir (site TT) and $1.20 \mu \mathrm{g} / \mathrm{g}$ dry weight $(0.28 \mu \mathrm{g} / \mathrm{g}$ wet weight $)$ in a pied-bill grebe egg sample from Leighton Pond (site LP). There is a paucity of information relating mercury concentrations in bird tissues to toxicological effects. Heinz (1979) reported that a mercury concentration of $0.9 \mu \mathrm{g} / \mathrm{g}$ wet weight in mallard eggs was associated with adverse behavioral effects. All mercury concentrations in egg samples from the Dolores Project area were much less than this concentration. Finley and others (1979) suggested that concentrations of mercury in excess of $20 \mu \mathrm{g} / \mathrm{g}$ wet weight in bird soft tissues should be considered hazardous. Mercury concentrations in bird-liver samples from the Dolores Project area ranged from $0.10 \mu \mathrm{g} / \mathrm{g}$ dry weight $(0.027 \mu \mathrm{g} / \mathrm{g}$ wet weight $)$ to $0.44 \mu \mathrm{g} / \mathrm{g}$ dry weight $(0.129 \mu \mathrm{g} / \mathrm{g}$ wet weight. 


\section{Aluminum}

Aquatic-plant and aquatic-invertebrate samples collected from the Dolores Project area had relatively high aluminum concentrations compared to the other trace elements. Aluminum concentrations in aquatic plants (including algae samples) ranged from $534 \mu \mathrm{g} / \mathrm{g}$ dry weight in a sago pondweed sample collected from Totten Reservoir (site TT) to $23,100 \mu \mathrm{g} / \mathrm{g}$ dry weight in an algae sample collected from Dawson Draw (site DD) (table 27). Aluminum concentrations in aquatic-invertebrate samples ranged from $240 \mu \mathrm{g} / \mathrm{g}$ dry weight in a crayfish sample from Totten Reservoir (site TT) to $13,600 \mu \mathrm{g} / \mathrm{g}$ dry weight in an aquatic-invertebrate sample from the Mancos River (site MN1). Aluminum concentrations in zooplankton samples ranged from $1,000 \mu \mathrm{g} / \mathrm{g}$ dry weight in a sample from McPhee Reservoir (site MP) to $6,590 \mu \mathrm{g} / \mathrm{g}$ dry weight in a sample from Puett Reservoir (site PU). Sparling (1990) reported that mallard ducklings exposed to a diet of about $11,000 \mu \mathrm{g} / \mathrm{g}$ dry weight aluminum had stunted growth and high mortality rates; ducklings exposed to a diet of about $5,500 \mu \mathrm{g} / \mathrm{g}$ dry weight aluminum had stunted growth and altered behavior. Aluminum concentrations in several of the aquatic-plant and a few aquatic-invertebrate samples are potentially hazardous to young aquatic birds, such as coots and waterfowl.

Aluminum concentrations in whole-body fish were extremely variable. Aluminum concentrations in whole-body fish from the four reservoirs were substantially less than the concentrations in whole-body fish from streams in the MVIC area. Brumbaugh and Kane (1985) reported that gastrointestinal-tract contents in fish contained highly variable amounts of aluminum and caused bias and increased variability when included in whole-body samples. Because whole-body fish samples from the Dolores Project area were submitted for laboratory analyses, actual aluminum concentrations in fish without the gastrointestinal-tract contents is unknown. Thus, it is unknown if there is an aluminum problem in the Dolores Project area.

\section{Arsenic}

Arsenic concentrations in most biota samples from the Dolores Project area were within the range for unpolluted environments. Arsenic concentrations in aquatic-plant samples ranged from $0.66 \mu \mathrm{g} / \mathrm{g}$ dry weight in an algae sample from site YJ1 to $18.3 \mu \mathrm{g} / \mathrm{g}$ dry weight in an algae sample from site CR (table 27). Moore and Ramamoorthy (1984) reported that arsenic is not a significant contaminant of aquatic-plant tissues, except at local point-source discharges, and residues are low (less than $50 \mu \mathrm{g} / \mathrm{g}$ dry weight) in most industrial-zone water. All samples from the Dolores Project area samples contained arsenic concentrations much less than $50 \mu \mathrm{g} / \mathrm{g}$ dry weight. Arsenic concentrations that exceeded reporting limits in aquatic-invertebrate samples ranged from $0.2 \mu \mathrm{g} / \mathrm{g}$ dry weight in an aquaticinvertebrate sample from site ME1 to $2.6 \mu \mathrm{g} / \mathrm{g}$ dry weight arsenic in a crayfish sample from Puett Reservoir (site PU). Moore and Ramamoorthy (1984) suggested arsenic residues in aquatic-invertebrates collected from unpolluted freshwater usually ranged from less than 0.5 to $20 \mu \mathrm{g} / \mathrm{g}$ dry weight. Arsenic concentrations in invertebrate samples from the Dolores Project area were much less than $20 \mu \mathrm{g} / \mathrm{g}$ dry weight. Arsenic concentrations in zooplankton samples collected from the Dolores Project area ranged from $0.8 \mu \mathrm{g} / \mathrm{g}$ dry weight in a sample from Totten Reservoir (site TT) to $4.4 \mu \mathrm{g} / \mathrm{g}$ dry weight in a sample from Summit Reservoir (site SU) (table 27).

Arsenic in seven whole-body fish samples exceeded the 1984 NCBP 85th-percentile arsenic concentration of $0.27 \mu \mathrm{g} / \mathrm{g}$ wet weight (Schmitt and Brumbaugh, 1990) (table 18). Moore and Ramamoorthy (1984) suggested that arsenic concentrations ranging from less than 0.1 to $0.4 \mu \mathrm{g} / \mathrm{g}$ wet weight $(1.6 \mu \mathrm{g} / \mathrm{g}$ dry weight at 75 percent moisture) in fish tissues are indicative of unpolluted to mildly contaminated water. Arsenic concentrations in three fish samples from streams in the MVIC area exceeded $0.4 \mu \mathrm{g} / \mathrm{g}$ wet weight; a fathead minnow sample from site ME3 had $0.63 \mu \mathrm{g} / \mathrm{g}$ wet weight arsenic, a flannelmouth sucker sample from site HD2 had $0.42 \mu \mathrm{g} / \mathrm{g}$ wet weight arsenic, and one bluehead sucker sample from site NW had $0.44 \mu \mathrm{g} / \mathrm{g}$ wet weight arsenic.

Eisler (1988a) suggested that arsenic concentrations of 2 to $10 \mu \mathrm{g} / \mathrm{g}$ wet weight in bird livers or kidneys should be considered elevated above background levels and that arsenic concentrations greater than $10 \mu \mathrm{g} / \mathrm{g}$ wet weight are indicative of arsenic poisoning. All arsenic concentrations in bird liver samples from the Dolores Project area were much less than these guidelines.

\section{Boron}

Eisler (1990) proposed that boron concentrations ranging from 30 to $100 \mu \mathrm{g} / \mathrm{g}$ wet weight in waterfowl diets may cause adverse effects. Two aquatic-plant samples contained boron concentrations that exceeded $30 \mu \mathrm{g} / \mathrm{g}$ wet weight (table 27). The boron concentration in a sago pondweed sample from Alkali Canyon (site AK) was $368 \mu \mathrm{g} / \mathrm{g}$ dry weight (about $53 \mu \mathrm{g} / \mathrm{g}$ wet 
weight) and in a pondweed sample from Cross Canyon (site CR) contained $345 \mu \mathrm{g} / \mathrm{g}$ dry weight (about $37 \mu \mathrm{g} / \mathrm{g}$ wet weight). Boron concentrations in two other aquatic-plant samples were slightly less than the $30 \mu \mathrm{g} / \mathrm{g}$ wet weight concentration; a sago pondweed sample from Summit Reservoir (site SU) contained $274 \mu \mathrm{g} / \mathrm{g}$ dry weight boron (about $28 \mu \mathrm{g} / \mathrm{g}$ wet weight), and a sago pondweed sample from Totten Reservoir (site TT) contained $256 \mu \mathrm{g} / \mathrm{g}$ dry weight boron (about $27 \mu \mathrm{g} / \mathrm{g}$ wet weight). All boron concentrations in aquatic-invertebrate samples were much lower than the dietary guideline for boron of $30 \mu \mathrm{g} / \mathrm{g}$ wet weight for waterfowl.

Saiki and May (1988) compiled data from various studies and suggested that background concentrations of boron in whole-body freshwater fish generally are less than $4.0 \mu \mathrm{g} / \mathrm{g}$ dry weight. Most of the boron concentrations in whole-body fish samples collected in the Dolores Project area were less than $4.0 \mu \mathrm{g} / \mathrm{g}$ dry weight. However, some samples from streams in the MVIC area contained boron concentrations that exceeded $4.0 \mu \mathrm{g} / \mathrm{g}$ dry weight. All boron concentrations in whole-body fish samples collected from reservoirs were equal to or less than $2.0 \mu \mathrm{g} / \mathrm{g}$ dry weight.

\section{Cadmium}

Cadmium concentrations in aquatic-plant samples from the Dolores Project area (table 27) were about equal to or less than cadmium concentrations reported in other studies (Moore and Ramamoorthy, 1984; Eisler, 1985; Schroeder and others, 1988; Stephens and others, 1988; Mueller and others, 1991). Cadmium concentrations in aquatic plants collected from the MVIC area were similar to concentrations in aquatic plants from the Dove Creek area. The highest cadmium concentration in an aquatic-plant sample was $3.7 \mu \mathrm{g} / \mathrm{g}$ dry weight from the San Juan River at site SJ1. Cadmium concentrations in aquatic-invertebrate samples (including crayfish) also were within background concentrations based on cadmium residues in aquatic invertebrates from other studies (Giesy and others, 1980; Moore and Ramamoorthy, 1984; Eisler, 1985). Zooplankton samples collected from the reservoirs also had relatively low cadmium concentrations and ranged from less than analytical reporting limits to $2.0 \mu \mathrm{g} / \mathrm{g}$ dry weight.

Cadmium concentrations in 63 whole-body fish samples exceeded the 1984 NCBP 85th-percentile concentration of $0.05 \mu \mathrm{g} / \mathrm{g}$ wet weight (Schmitt and Brumbaugh, 1990) (table 18). Analytical reporting limits exceeded the 85th-percentile concentration for some samples; therefore, the actual number of samples exceeding the 85th percentile is not known. Schmitt and Brumbaugh (1990) reported that common carp seem to accumulate cadmium more readily than other fish species and reported a maximum concentration of $0.22 \mu \mathrm{g} / \mathrm{g}$ wet weight in a common carp sample collected in 1984. Cadmium concentrations in eight whole-body fish samples from the Dolores Project area exceeded the 1984 maximum concentration, most often in sucker samples. The highest cadmium concentration in fish samples was $3.5 \mu \mathrm{g} / \mathrm{g}$ dry weight (1.16 wet weight) in a speckled dace sample from site ME2 (table 27). Eisler (1985) indicated that cadmium concentrations in whole-body vertebrates that exceed $2 \mu \mathrm{g} / \mathrm{g}$ wet weight or $10 \mu \mathrm{g} / \mathrm{g}$ fresh weight (same as wet weight) in the kidney or liver should be considered as evidence of probable cadmium contamination. Eisler (1985) also reported that a cadmium concentration of $5.0 \mu \mathrm{g} / \mathrm{g}$ wet weight $(20 \mu \mathrm{g} / \mathrm{g}$ dry weight at 75 -percent moisture) in a whole-body estuarine fish as potentially life-threatening. All cadmium concentrations in whole-body fish and organ samples from the Dolores Project area were less than these concentrations.

Cadmium concentrations were relatively low in bird samples from the Dolores Project area. All cadmium concentrations were less than guideline concentrations for vertebrates suggested by Eisler (1985) as indicative of contamination.

\section{Chromlum}

Moore and Ramamoorthy (1984) reported that chromium is not a significant contaminant in aquatic-plant tissues, except at site-specific discharge points, and that concentrations in freshwater aquatic plants seldom exceed $5 \mu \mathrm{g} / \mathrm{g}$ dry weight. Moore and Ramamoorthy (1984) reported that chromium concentrations in freshwater aquatic plants collected from industrial sources are as much as $50 \mu \mathrm{g} / \mathrm{g}$ dry weight. Forty-one of the 54 aquatic-plant samples.collected from the Dolores Project area contained chromium concentrations that exceeded $5 \mu \mathrm{g} / \mathrm{g}$ dry weight, including 32 samples from streams in the MVIC area, 6 from streams in the Dove Creek area, and 3 from the San Juan River (table 27). The highest chromium concentration in aquatic vegetation was $37 \mu \mathrm{g} / \mathrm{g}$ dry weight in an algae sample from site YJ2 (table 27).

Moore and Ramamoorthy (1984) reported that chromium concentrations in aquatic-invertebrate samples collected from polluted freshwater can be as much as $25 \mu \mathrm{g} / \mathrm{g}$ dry weight, compared to less than $5 \mu \mathrm{g} / \mathrm{g}$ dry weight for unpolluted water. Twelve of the 54 aquaticinvertebrate samples (including crayfish, earthworms, and snails) contained chromium concentrations that 
exceeded $5 \mu \mathrm{g} / \mathrm{g}$ dry weight, and included 6 samples from streams in the MVIC area, 3 samples from the streams in the Dove Creek area, 2 samples from the Mancos River, and 1 sample from the San Juan River (table 27). The highest chromium concentration in an aquatic-invertebrate sample was $440 \mu \mathrm{g} / \mathrm{g}$ dry weight in a crayfish sample collected from site MN2 on the Mancos River (table 27). Seven of the eight zooplankton samples collected from reservoirs in the MVIC area contained chromium concentrations that exceeded $5 \mu \mathrm{g} / \mathrm{g}$ dry weight, and the highest concentration was $25 \mu \mathrm{g} / \mathrm{g}$ dry weight in a zooplankton sample from McPhee Reservoir (site MP) (table 27).

Eisler (1986a) indicated that chromium concentrations exceeding $4 \mu \mathrm{g} / \mathrm{g}$ dry weight in organs and tissue of fish and wildlife should be viewed as presumptive evidence of chromium contamination. Forty-three of the 181 whole-body fish samples from the Dolores Project area had chromium concentrations that exceeded $4 \mu \mathrm{g} / \mathrm{g}$ dry weight. Of these 43 samples, 33 were collected from streams in the MVIC area, 2 were collected from streams in the Dove Creek area, 3 were collected from the Mancos River, 4 were collected from the San Juan River, and 1 sample was collected from the reservoirs. At least one of the wholebody fish samples collected at sites ME4, SD, HD2, DD, WC, MN1, SJ1, and SJ3 had chromium concentrations that exceeded $10 \mu \mathrm{g} / \mathrm{g}$ dry weight (table 27), which is 2.5 times the guideline concentration suggested by Eisler (1986a). Moore and Ramamoorthy (1984) reported that chromium does not normally accumulate in fish and that chromium concentrations in the muscle of freshwater fish generally are less than 0.25 $\mu \mathrm{g} / \mathrm{g}$ wet weight. A walleye fillet sample from Totten Reservoir (site TT) had a chromium concentration of $2.6 \mu \mathrm{g} / \mathrm{g}$ dry weight (about $0.63 \mu \mathrm{g} / \mathrm{g}$ wet weight), about 2.5 times the value expected in freshwater fish muscle. All chromium concentrations in tissues of birds collected from the Dolores Project area were less than the guideline of $4 \mu \mathrm{g} / \mathrm{g}$ dry weight (Eisler 1986a). Chromium and other trace metals may have been transported into irrigated areas of the Dolores Project, especially into the MVIC area, in the irrigation water supply from the Dolores River basin.

\section{Copper}

Moore and Ramamoorthy (1984) reported that copper concentrations in attached species of aquatic plants inhabiting polluted water generally ranged between 10 and $100 \mu \mathrm{g} / \mathrm{g}$ dry weight. Copper concentrations in aquatic-plant samples from the Dolores Project area ranged from $2.2 \mu \mathrm{g} / \mathrm{g}$ dry weight in an algae sample from site WC to $32.9 \mu \mathrm{g} / \mathrm{g}$ dry weight in an algae sample from site CR (table 27). Moore and Ramamoorthy (1984) also reported that aquaticinvertebrates inhabiting polluted freshwater generally had copper concentrations of 5 to $200 \mu \mathrm{g} / \mathrm{g}$ dry weight. Copper concentrations in aquatic-invertebrate samples from the Dolores Project area ranged from $4 \mu \mathrm{g} / \mathrm{g}$ dry weight in a snail sample from site WC to $134 \mu \mathrm{g} / \mathrm{g}$ dry weight in a crayfish sample from site YJ2 (table 27).

Copper concentrations in 83 of 181 whole-body fish samples exceeded the 1984 NCBP 85th-percentile of $1.0 \mu \mathrm{g} / \mathrm{g}$ wet weight (table 18). Of these 83 samples, 48 were collected from streams in the MVIC area, 1 from a stream in the Dove Creek area, 13 from the Mancos River, 16 from the San Juan River, and 5 were from the reservoirs. Moore and Ramamoorthy (1984) reported that a toxic copper concentration in wholebody fish has not yet been determined; however, they reported that copper concentrations in muscle tissue seldom exceeded $1.0 \mu \mathrm{g} / \mathrm{g}$ wet weight. A copper concentration of $5.6 \mu \mathrm{g} / \mathrm{g}$ dry weight $(1.5 \mu \mathrm{g} / \mathrm{g}$ wet weight) in a fillet sample taken from a flannelmouth sucker collected in the San Juan River (site SJ1) was the only fillet sample that exceeded $1.0 \mu \mathrm{g} / \mathrm{g}$ wet weight copper.

\section{Lead}

Lead concentrations in aquatic-plant and aquatic-invertebrate samples from the Dolores Project area were relatively low compared to other studies (Moore and Ramamoorthy, 1984; Eisler 1988b). Lead concentrations in 40 of the 181 whole-body fish samples collected in the Dolores Project area exceeded the 1984 NCBP 85th-percentile concentration of $0.22 \mu \mathrm{g} / \mathrm{g}$ wet weight (Schmitt and Brumbaugh, 1990) (table 18). Of these samples, 19 were collected from streams in the MVIC area, 15 were collected from the San Juan River, and 6 were collected from the Mancos River. Several samples had lead concentrations with analytical reporting limits exceeding the NCBP 85th-percentile concentration, so it is unknown if those concentrations exceeded the 85th percentile. The toxic lead concentration in whole-body fish has not yet been determined (Saiki and Palawski, 1990).

\section{Zinc}

Zinc concentrations in 44 of the 181 whole-body fish samples collected in the Dolores Project area exceeded the 1984 NCBP 85th-percentile concentration of $34.2 \mu \mathrm{g} / \mathrm{g}$ wet weight (Schmitt and Brumbaugh, 1990) (table 18). Of these samples, 32 were collected from streams in the MVIC area, 2 from streams in the 
Dove Creek area, 3 from the Mancos River, 6 samples from the San Juan River, and 1 sample from the reservoirs. Schmitt and Brumbaugh (1990) reported that common carp apparently accumulate zinc to a greater extent than other fish species. Of the 44 wholebody fish samples that exceeded the 1984 NCBP 85th-percentile, 9 were common carp that had zinc concentrations ranging from 169 to $596 \mu \mathrm{g} / \mathrm{g}$ dry weight (table 27). The toxicological significance of these zinc concentrations is unknown. Saiki and Palawski (1990) reported zinc concentrations in juvenile striped bass that were as much as $170 \mu \mathrm{g} / \mathrm{g}$ dry weight, and none of the fish were in poor condition. Zinc concentrations in fish fillets from reservoir sites were substantially lower than concentrations in wholebody fish collected from the same sites (table 27). Whole-body fish often contain substantial amounts of contaminated material in the gastrointestinal tract (Saiki and Palawski, 1990), which could account for higher zinc concentrations in whole-body fish when compared to fillets. Zinc concentrations in fish eggs from Summit, Puett, and Totten Reservoirs (sites SU, PU, TT) (table 27) ranged from $56.2 \mu \mathrm{g} / \mathrm{g}$ dry weight to $217 \mu \mathrm{g} / \mathrm{g}$ dry weight. Evidently, zinc concentrations are deposited into the eggs of female fish.

\section{Organochlorine Pesticides}

Concentrations of organochlorine pesticides and PCBs in fish and bird samples from the Dolores Project area generally were low and within the range of background concentrations (Fleming and others, 1983; White and others, 1983; DeWeese and others, 1986; Eisler, 1986b, 1987b; Schmitt and others, 1990) (table 28). All organochlorine concentrations in fish samples from the Dolores Project area (table 28) were less than or equal to the 1984 NCBP geometric mean concentrations (table 21). The organic compound p,p'-DDE, which is the most persistent degradation product of $\mathrm{p}, \mathrm{p}^{\prime}-\mathrm{DDT}$, was the organochlorine pesticide detected most often in biota samples from the Dolores Project area (table 28).

\section{Polycyclic Aromatic Hydrocarbons}

Polycyclic aromatic hydrocarbons (PAHs) are ubiquitous in nature. Natural processes such as forest fires, microbial synthesis, and volcanic activity result in PAHs in sediment, soil, air, surface water, and plant and animal tissues (Eisler, 1987b). Anthropogenic sources of PAHs in the Four Corners area include coalfired power plants and oil refineries that generate aromatic hydrocarbons from high temperature (greater
Table 21. National Contaminant Biomonitoring Program (NCBP) geometric mean concentrations of selected organochlorine pesticides and PCB's for 1984

[Concentrations in micrograms per gram wet weight; geometric mean concentrations from Schmitt and others (1990)]

\begin{tabular}{lc}
\hline Compound & $\begin{array}{c}\text { NCBP geomotric mean } \\
\text { concentration }\end{array}$ \\
\hline p,p'-DDE & 0.19 \\
p,p'-DDD & .06 \\
p,p'-DDT & .03 \\
Total DDT & .26 \\
Heptachlor & .01 \\
cis-chlordane & .03 \\
trans-chlordane & .02 \\
cis-nonachlor & .02 \\
trans-nonachlor & .03 \\
oxychlordane & .01 \\
Total PCB's & .39 \\
\hline
\end{tabular}

than $700^{\circ} \mathrm{C}$ ) pyrolysis of organic materials. These sources can produce localized areas of PAH contamination (Eisler, 1987b).

Fish-bile samples were collected as an indicator of PAH exposure at seven stream sites and three reservoirs within the Dolores study area (table 29). Bile is a sensitive indicator for assessing the exposure of fish to PAHs (McDonald and others, 1991). High concentrations of PAH metabolites in bile indicate actual exposure, and high concentrations of PAHs in sediment indicate a potential for exposure (Johnston and Baumann, 1989). The bile samples were analyzed for naphthalene, phenanthrene, and benzo[a]pyrene using high performance liquid chromatography and fluorescence detection by Texas A\&M University Geotechnical and Environmental Research Group, a contract laboratory for the U.S. Fish and Wildlife Service. Bile samples were collected for this project because of concern levels of PAHs in fish bile samples collected during the San Juan reconnaissance investigation in the San Juan River Basin in northern New Mexico.

Of the three compounds analyzed, only benzo[a]pyrene is a known carcinogen. Benzo[a]pyrene generally is associated with anthropogenic activities such as coke production, catalytic cracking in the petroleum industry, manufacturing of asphalt, fossil fuel combustion for heating and power generation, open burning, and internal combustion engines (Eisler, 1987b). Naphthalene and phenanthrene are indicators of exposure to PAHs but are not considered to be very toxic or carcinogenic (Eisler, 1987b). Eisler (1987b) 
also reports that selenium can be an effective inhibitor of PAH-induced tumor development.

Eisler (1987b) reports that criteria or standards have not been promulgated for PAHs by any regulatory agency for the protection of sensitive species of aquatic organisms or wildlife. The highest concentration of PAHs was in a channel catfish collected near Four Corners on the San Juan River (site SJ1 in table 29). A flannelmouth sucker also was collected at this site, but the PAH concentrations were much lower for the sucker than for the channel catfish. Susan McDonald (Texas A and M Research Foundation, oral commun., 1993) stated that flannelmouth suckers may not be a good indicator species of PAH contamination because they tend to have much lower concentrations of PAHs than other fish species. However, in the Dolores project area, flannelmouth suckers were selected because of their widespread distribution.

At Alkali Canyon (site AK), bile was collected from five flannelmouth suckers in November 1990 (table 29). This composite bile sample had the lowest PAH concentration within the study area. Site AK was considered a control site for PAHs in the Dolores Project area and for the San Juan study area because of the low concentrations in the November samples. Five additional bile samples collected at site AK in August 1991 (table 29) had PAH values much higher than in November 1990, indicating an exposure to PAHs had occurred some time after November 1990 . The five fish collected in August 1991 were collected from the same pool and were similar in size $(500 \mathrm{~mm})$ and weight $(2,500 \mathrm{~g})$ to the five fish collected in November 1990.

\section{SUMMARY}

During the last several years, there has been increasing concern about the quality of irrigation drainage and its potential harmful effects on human health, fish, and wildlife. The U.S. Department of the Interior (DOI) initiated a program in 1985 to identify the nature and extent of irrigation-induced water-quality problems that might exist in the Western United States. Twenty-four reconnaissance investigations were completed through 1990 to determine if irrigation drainage has significantly affected human health, fish, and wildlife or has adversely affected the suitability of water for other beneficial uses.

This report describes results of a reconnaissance investigation of the Dolores Project area in southwestern Colorado done during 1990-91. The study area extended into southeastern Utah along the lower San Juan River. The project diverts water from McPhee Reservoir, in the Dolores River basin, for irrigation and municipal supplies in the San Juan River basin. The
Dolores Project furnishes supplemental water to the area served by the Montezuma Valley Irrigation Company (MVIC). The MVIC area is located primarily in the Mc Elmo Creek basin and has been irrigated since the 1880's. The project provides all the irrigation water to the newly irrigated areas (since 1987) between Yellow Jacket Canyon and Dove Creek (the Dove Creek area), and will furnish water for irrigation on the Ute Mountain Ute Reservation (the Towaoc area) by 1994. One objective of the reconnaissance investigation was to determine if there were potentially harmful concentrations of trace elements or pesticides in water, bottom sediment, and biota in the long-term irrigated areas and in areas where irrigation recently began. Another objective was to determine if there were potentially harmful concentrations of contaminants in the Mancos River and San Juan River in the project area.

Dissolved-solids and sulfate concentrations in most water samples collected for the reconnaissance investigation exceeded the secondary maximum contaminant levels for those constituents. Dissolvedsolids concentrations exceeded $500 \mathrm{mg} / \mathrm{L}$ in samples collected during the pre-irrigation season from streams draining the MVIC area, the Dove Creek area, and from the Mancos River. The MVIC area is a significant source of dissolved solids to Mc Elmo Creek. Dissolved-solids loads in the streams draining the newly irrigated areas north of Yellow Jacket Canyon were much smaller than the loads in streams draining the MVIC area. The Mancos River and Mc Elmo Creek may be significant sources of dissolved solids to the San Juan River.

The only dissolved trace-element concentrations that exceeded U.S. Environmental Protection Agency drinking-water regulations, aquatic-life criteria, or Colorado agricultural-use criteria were cadmium, mercury, and selenium. Cadmium was detected in 19 water samples collected at 16 sites. The maximum cadmium concentration was $4 \mu \mathrm{g} / \mathrm{L}$ in a sample from Puett Reservoir collected in November 1990. Cadmium concentrations exceeded the chronic aquatic-life criterion in two water samples; one sample was from Summit Reservoir and the other sample was from Puett Reservoir. Both reservoirs are reference sites located outside irrigated areas served by the Dolores Project. Cadmium was detected in at least one water sample from most sites within the MVIC area. Mercury was detected in 11 water samples at concentrations that ranged from 0.1 to $1.2 \mu \mathrm{g} / \mathrm{L}$; however, 6 of those samples were collected at reference sites. The maximum concentration of mercury was $1.2 \mu \mathrm{g} / \mathrm{L}$ in a sample collected outside of the irrigated area from a seep area along the San Juan River at Aneth, Utah. The source of the seep is ground- 
water discharge from bedrock. Mercury was not detected in samples from the San Juan River.

Although neither dissolved cadmium or dissolved mercury were detected in the four samples collected from outflow from McPhee Reservoir, transport of cadmium, mercury, and other trace elements from the Dolores River basin into the irrigated areas may be associated with suspended sediment in water. Water has been diverted from the Dolores River into the MVIC area for about 100 years. Metal mining began in the upper Dolores River basin in the 1870's, and the numerous mined areas may have been a source of trace elements to the irrigation water supply for the Dolores Project area.

Selenium was detected in 36 water samples collected at 15 sites. The only selenium concentration that exceeded the MCL for selenium in drinking water $(50 \mu \mathrm{g} / \mathrm{L})$ was $88 \mu \mathrm{g} / \mathrm{L}$ in a sample from Navajo Wash, which drains irrigated areas on Mancos Shale in the southern MVIC area. That concentration also was the maximum selenium concentration in a water sample collected in the Dolores Project area. Selenium concentrations in 18 surface-water samples and 1 groundwater sample exceeded $5 \mu \mathrm{g} / \mathrm{L}$, which is the U.S. Environmental Protection Agency's chronic criterion for selenium for protection of aquatic life.

Selenium was detected in all water samples collected from Mc Elmo Creek downstream from irrigated land in the MVIC area at concentrations that ranged from 2 to $9 \mu \mathrm{g} / \mathrm{L}$. Irrigation water from $\mathrm{McPhee}$ Reservoir had less than $1 \mu \mathrm{g} / \mathrm{L}$ of selenium and the selenium load in Mc Elmo Creek upstream from the MVIC area was very small, indicating that the MVIC area is the primary source of selenium to Mc Elmo Creek. If selenium concentrations in Navajo Wash are typical of selenium concentrations in irrigation drainwater from the gray-soil areas south of Mc Elmo Creek, then irrigation drainage from gray-soil areas may be the primary source of selenium to Mc Elmo Creek. Only 1 of the 15 water samples collected from streams draining the MVIC area north of Mc Elmo Creek had a selenium concentration greater than $1 \mu \mathrm{g} / \mathrm{L}$.

In contrast to the northern MVIC area, selenium was detected in all water samples collected from three small streams in the newly (since 1987) irrigated areas north of the MVIC area. Long-term irrigation may have leached much of the soluble selenium from soils in the northern MVIC area, but the soluble selenium has not been leached from soils in newly irrigated areas. The selenium concentrations in samples collected in newly irrigated areas ranged from 3 to $12 \mu \mathrm{g} / \mathrm{L}$ and exceeded the chronic aquatic-life criterion of $5 \mu \mathrm{g} / \mathrm{L}$ in six of eight samples. Selenium loads in the
Dove Creek area were very small because stream discharges were small (less than $0.25 \mathrm{ft}^{3} / \mathrm{s}$ ).

Selenium concentrations in the Mancos River ranged from 3 to $10 \mu \mathrm{g} / \mathrm{L}$. The Mancos Project, a Federal irrigation project in the upper Mancos River basin, may be a source of some of the selenium in the Mancos River. Concentrations of selenium in the San Juan River did not exceed $2 \mu \mathrm{g} / \mathrm{L}$. Concentrations of selenium in the San Juan River at Four Corners were equal to the concentrations at Mexican Hat, Utah, for the three sampling surveys in 1990.

The herbicides 2,4-D, and dicamba were detected in most of the 14 water samples collected in the Dolores Project area in July 1990. Picloram was detected in five samples, and malathion was detected in one sample. Pesticide concentrations in water were considerably less than the levels harmful to aquatic life.

Trace-element concentrations in bottom sediment collected in the Dolores Project area generally were within the baseline ranges for soils in the Western United States and within concentration ranges reported from previous DOI reconnaissance investigations.

Selenium concentrations in bottom-sediment samples from Cahone Canyon, Woods Canyon, Navajo Wash, and the Mancos River exceeded the upper baseline for soils $(1.4 \mu \mathrm{g} / \mathrm{g})$. Those sites also had some of the larger selenium concentrations in water samples.

Six pesticides were detected in bottom-sediment samples from the Dolores Project area. The maximum pesticide concentration in bottom sediment was $5.5 \mu \mathrm{g} / \mathrm{kg}$ of DDD in the sample from Summit Reservoir, which is a reference site located outside irrigated areas of the Dolores Project.

Biota data collected by the U.S. Fish and Wildlife Service for a field screening study of the Mancos River basin in July 1989, indicated elevated selenium concentrations in some biota samples collected within and downstream from the Mancos Project. Selenium concentrations in 7 of 10 whole-body fish samples equaled or exceeded $4 \mu \mathrm{g} / \mathrm{g}$ dry weight, which is a guideline concentration of concern for freshwater fish. Selenium concentrations ranged from 10 to $69 \mu \mathrm{g} / \mathrm{g}$ dry weight in six bird-tissue samples collected from a pond located within the irrigated area of the Mancos Project. The selenium concentrations in the bird samples indicate that bioaccumulation of selenium is occurring in the Mancos Project, which is upstream from the Dolores Project.

Only 5 of 54 aquatic-plant and algae samples collected in the Dolores Project area in 1990 had selenium concentrations exceeding the recommended guideline of $3 \mu \mathrm{g} / \mathrm{g}$ dry weight for food items consumed by fish and wildlife, and 4 of those samples were from the 
Dove Creek area. Five aquatic-invertebrate samples from Navajo Wash had selenium concentrations exceeding $3 \mu \mathrm{g} / \mathrm{g}$, but only three other aquaticinvertebrate samples from the MVIC area had selenium concentrations exceeding $3 \mu \mathrm{g} / \mathrm{g}$. Ten of 11 aquaticinvertebrate samples from the Dove Creek area had selenium concentrations exceeding the guideline of $3 \mu \mathrm{g} / \mathrm{g}$ dry weight, and the maximum concentration was $19.2 \mu \mathrm{g} / \mathrm{g}$ dry weight in an aquatic-invertebrate sample from Woods Canyon. Geometric mean selenium concentrations for aquatic plants and aquatic invertebrates were higher for the Dove Creek area than for the MVIC area.

Geometric mean selenium concentrations were higher in suckers (whole-body samples) from the Mancos River than in suckers from the MVIC area (except for suckers from Navajo Wash) or from the San Juan River. Selenium concentrations in only 4 of 46 sucker samples from the MVIC area exceeded the 1984 NCBP 85th-percentile concentration, and two of those samples were from Navajo Wash. The selenium concentrations in sucker samples correlated with the selenium concentrations in water samples for streams in the MVIC area. Selenium concentrations in seven of eight sucker samples collected from the Mancos River exceeded the NCBP 85th-percentile concentration for selenium, and four of those concentrations exceeded $4 \mu \mathrm{g} / \mathrm{g}$ dry weight, which is a guideline for selenium concentrations of concern for freshwater fish.

The mean selenium concentration was significantly higher in sucker samples collected from the San Juan River at Mexican Hat, Utah, which is downstream from the Dolores Project, than in sucker samples collected in the San Juan River at Four Corners, which is upstream from most irrigation of the Dolores Project. Suckers apparently accumulated more selenium at Mexican Hat than at Four Corners, although selenium concentrations in water samples from the two sites were equal for the three sampling surveys in 1990. Juvenile Colorado squawfish have been found in the San Juan River near the Mancos River confluence, but data collected by the reconnaissance investigation are not sufficient to assess effects of irrigation drainage from the Dolores Project on endangered fish in the San Juan River.

Other fish species collected in the Dolores project area, such as common carp, fathead minnows, and speckled dace, tended to have higher selenium concentrations than suckers. Eleven of twelve common carp whole-body samples had selenium concentrations that exceeded the NCBP 85th percentile, and six of those exceeded $4 \mu \mathrm{g} / \mathrm{g}$ dry weight. Selenium concentrations in more than one-half of fathead minnow samples exceeded the NCBP 85th percentile. The highest selenium concentrations in fathead minnows were in samples from lower Yellow Jacket Canyon, Woods Canyon, and from the Mancos River, and the maximum concentration was $26.4 \mu \mathrm{g} / \mathrm{g}$ dry weight in a sample from Woods Canyon. Some fathead minnows from those basins had selenium concentrations associated with adverse effects reported in the literature. Almost all selenium concentrations in speckled dace exceeded the NCBP 85th-percentile concentration, and most concentrations exceeded the concentration of concern of $4 \mu \mathrm{g} / \mathrm{g}$ for whole-body fish samples. As with water samples and other biota samples, the highest selenium concentrations in speckled dace in the MVIC area were in samples from Navajo Wash.

Selenium concentrations in piscivorous fish samples from reservoirs in the Dolores Project area generally were less than the concentrations in fish samples from streams. Selenium concentrations in fillet and egg samples of piscivorous fish were less than concentrations of concern.

The geometric mean selenium concentration in 15 bird eggs (different species) collected in the Dolores Project area was $3.6 \mu \mathrm{g} / \mathrm{g}$ dry weight, and the mean concentration in 9 bird livers was $6.0 \mu \mathrm{g} / \mathrm{g}$ dry weight. The mean concentration for eggs is within the range of uncertainty for biological significance, and the mean concentration for livers is less than the mean baseline concentration of $10 \mu \mathrm{g} / \mathrm{g}$ dry weight. Bird-tissue samples that had the highest selenium concentrations were collected in the Dove Creek area and included $37.5 \mu \mathrm{g} / \mathrm{g}$ dry weight in a mallard liver from Woods Canyon, and $18.5 \mu \mathrm{g} / \mathrm{g}$ dry weight in a coot egg from a pond in Alkali Canyon, a tributary of Cross Canyon.

The only mercury concentrations in biota that may be of concern in the Dolores Project area are in warm-water game fish from reservoirs. Advisories were posted in 1991 at McPhee and Narraguinnep Reservoirs by the Colorado Department of Health concerning elevated mercury concentrations in game fish. Based on mercury data collected from 1988-91 and the risk assessment method used by the Colorado Department of Health, weekly human consumption guidelines were computed for adults, children, and pregnant women. The amount of fish that can safely be consumed varied by fish species and by site. The most restrictive consumption limits were for walleye, bass, and northern pike. The weekly consumption limits for adults ranged from $0 \mathrm{oz} /$ week for walleye from Narraguinnep Reservoir to $58 \mathrm{oz} /$ wk for kokanee salmon from McPhee Reservoir.

A few aluminum concentrations in aquatic-plant and aquatic-invertebrate samples from the Dolores Project area may be potentially hazardous to young 
aquatic birds, such as coots and waterfowl. Arsenic concentrations in biota were representative of unpolluted environments or were less than background concentrations. Two boron concentrations in aquatic plants and a few concentrations in whole-body fish were elevated compared to information in the literature, but boron probably is not a concern in biota in the Dolores Project area.

Cadmium concentrations in biota generally were within background concentrations reported in the literature except for a number of whole-body fish samples. Cadmium concentrations in about 50 percent of wholebody fish samples from the MVIC area exceeded the 1984 NCBP 85th percentile of $0.05 \mu \mathrm{g} / \mathrm{g}$ wet weight for cadmium. Eight cadmium concentrations in wholebody fish from the Dolores Project area exceeded the maximum concentration for the 1984 NCBP data of $0.22 \mu \mathrm{g} / \mathrm{g}$ wet weight. The maximum cadmium concentration from the Dolores Project area of $3.5 \mu \mathrm{g} / \mathrm{g}$ dry weight $(1.16 \mu \mathrm{g} / \mathrm{g}$ wet weight) was in a speckled dace collected from Mc Elmo Creek downstream from Cortez. However, cadmium concentrations in fish were less than concentrations reported in the literature that indicate cadmium contamination. Although chromium concentrations in water and bottom-sediment samples from the Dolores Project area were not elevated, chromium concentrations in a significant number of aquatic-plant, aquatic-invertebrate, and whole-body fish samples from the project area are indicative of chromium contamination. The maximum chromium concentration in a biota sample was $440 \mu \mathrm{g} / \mathrm{g}$ dry weight in a crayfish from the lower Mancos River. Cadmium and chromium could have been transported into the Dolores Project area in the irrigation water diverted from the Dolores River basin.

Copper concentrations in 83 whole-body fish samples and lead concentrations in 41 whole-body fish samples exceeded the 1984 NCBP 85th-percentile concentrations for those trace elements. Toxic concentrations of copper and lead in fish have not been determined. Zinc concentrations in 44 whole-body fish samples exceeded the 1984 NCBP 85 th percentile, and 32 of the samples were from the MVIC area. However, the toxicological significance of the zinc concentrations is not known.

Concentrations of organochlorine pesticides and PCB's in fish and birds in the Dolores Project area were within the range of background concentrations. Fishbile samples from seven streams and three reservoirs were analyzed for 3 PAH compounds. The highest PAH concentrations were in a channel catfish from the San Juan River at Four Corners, but the biological significance of PAH concentrations are not known.

\section{REFERENCES CITED}

Britton, L.J., and Greeson, P.E., eds., 1988, Methods for collection and analysis of aquatic biological and microbiological samples: U.S. Geological Survey Techniques of Water-Resources Investigations, book 5, chap. A4, $363 \mathrm{p}$.

Bodaly, R.A., Hecky, R.E., and Fudge, R.J.P., 1984, Increases in fish mercury levels in lakes flooded by the Churchill River diversion, northern Manitoba: Canadian Journal of Fisheries and Aquatic Science, v. 41, no. 4, p. 682-691.

Brumbaugh, W.G., and Kane, D.A., 1985, Variability of aluminum concentrations in organs and whole bodies of smallmouth bass (Micropterus dolomieui): Environmental Science and Technology, v. 19, no. 9, p. 828-831.

Bureau of Indian Affairs, 1965, Soil and range inventory of the Ute Mountain Indian Reservation, Colorado and New Mexico: Albuquerque, New Mexico, 16 p.

Bureau of Reclamation, 1977a, Dolores Project, Colorado, Definite plan report appendix B-Water supply: Salt Lake City, Upper Colorado Region, 166 p. 1977b, Dolores Project, Colorado, Definite plan report, appendix C-Project lands and drainage: Salt Lake City, Upper Colorado Region, variously paged. 1981, Mc Elmo Creek Unit, Colorado-Status report, July 1981: Salt Lake City, Upper Colorado Region, $26 \mathrm{p}$. 1988, Dolores Project, Colorado, supplement to definite plan report, appendix B-Water supply and hydrosalinity: Salt Lake City, Upper Colorado Region, 131 p. 1989, Final supplement to the final environmental statement-Dolores Project, Montezuma and Dolores Counties, Colorado: Bureau of Reclamation Report FES 89-10, $178 \mathrm{p}$.

Colorado Department of Health, 1986, Classification and numeric standards for San Juan River and Dolores River basins, section 3.4.0: Denver, Colo., Water Quality Control Commission, p. 78-134.

1989, The basic standards and methodologies for surface water, section 3.1.0: Denver, Colo., Water Quality Control Commission, 111 p.

1992, Health effects of mercury in Colorado fish: Denver, Colo., Colorado Department of Health, Colorado Disease Bulletin, v. 19, no. 15, Aug. 7, 1992.

Cumbie, P.M., and Van Horn, S.L., 1978, Selenium accumulation associated with fish mortality and reproductive failure: Annual conference of the Southeast Association of Fish and Wildlife Agencies, proceedings, v. 32, p. 612-624.

DeWeese, L.R., McEwen, L.C., Hensler, G.L., and Peterson, B.E., 1986, Organochlorine contaminants in passeriforms and other avian prey of the peregrine falcon in the 
Western United States: Environmental Toxicology and Chemistry, v. 5, no. 7, p. 675-693.

Edwards, T.K., and Glysson, G.D., 1988, Field methods for measurement of fluvial sediments: U.S. Geological Survey Open-File Report 86-531, 118 p.

Eisler, Ronald, 1985, Cadmium hazards to fish, wildlife, and invertebrates-A synoptic review: U.S. Fish and Wildlife Service Biological Report 85(1.2), 46 p. 1986a, Chromium hazards to fish, wildlife, and invertebrates-A synoptic review: U.S. Fish and Wildlife Service Biological Report 85(1.6), 60 p. 1986b, Polychlorinated biphenyl hazards to fish, wildlife, and invertebrates-A synoptic review: U.S. Fish and Wildlife Service Biological Report 85(1.7), 72 p. 1987a, Mercury hazards to fish, wildlife, and invertebrates-A synoptic review: U.S. Fish and Wildlife Service Biological Report 85(1.10), 90 p. $1987 \mathrm{~b}$, Polycyclic aromatic hydrocarbon hazards to fish, wildlife, and invertebrates-A synoptic review: U.S. Fish and Wildlife Service Biological Report 85(1.11), 81 p. 1988a, Arsenic hazards to fish, wildlife, and invertebrates-A synoptic review: U.S. Fish and Wildlife Service Biological Report 85(1.12), 92 p. 1988b, Lead hazards to fish, wildlife, and invertebrates-A synoptic review: U.S. Fish and Wildlife Service Biological Report 85(1.14), 134 p. 1990 , Boron hazards to fish, wildlife, and invertebrates-A synoptic review: U.S. Fish and Wildlife Service Biological Report 85(1.20), 32 p.

Fassett, J.E., and Hinds, J.S., 1971, Geology and fuel resources of the Fruitland Formation and Kirtland Shale of the San Juan basin, New Mexico and Colorado: U.S. Geological Survey Professional Paper 676, 76 p. [reprinted 1977]

Finley, M.T., Stickel, W.H., and Christensen, R.E., 1979, Mercury residues in tissues of dead and surviving birds fed methyl mercury: Environmental Contaminants and Toxicology Bulletin, v. 21, p. 105-110.

Fishman, M.J., and Friedman, L.C., eds., 1989, Methods for determination of inorganic substances in water and fluvial sediments (3rd ed.): U.S. Geological Survey Techniques of Water-Resources Investigations, book 5 , chap. A1, 545 p.

Fleming, W.J., Clark, D.R., Jr., and Henny, C.J., 1983, Organochlorine pesticides and PCB's-A continuing problem for the 1980's: The 48th North American Management Institute Transactions, p. 186-199.

Geldon, A.L., 1985, Water resources of the Cottonwood Wash watershed, Ute Mountain Ute Indian Reservation, Southwestern Colorado: U.S. Geological Survey Water-Resources Investigations Report 85-4027, 56 p.

Giesy, J.P., Bowling J.W., and Kania, H.J., 1980, Cadmium and zinc accumulation and elimination by freshwater crayfish: Archives of Environmental Contaminants and Toxicology, v. 9, p. 683-697.

Hamilton, S.J., Palmisano, A.N., Wedemeyer, G.A., and Yasutake, W.T., 1990, Impacts of selenium on early life stages and smoltification of fall chinook salmon: Transactions of the 51st North American Wildlife and Natural Resources conference, p. 343-356.

Haynes, D.D., Vogel, J.D., and Wyant, D.G., comps., 1972, Geology, structure, and uranium deposits of the Cortez quadrangle, Colorado and Utah: U.S. Geological Survey Miscellaneous Investigations Series Map I-629, scale $1: 250,000,2$ sheets.

Heinz, G.H., 1979, Methylmercury-Reproductive and behavioral effects on three generations of mallard ducks: Journal of Wildlife Management, v. 43, no. 2, p. 394-401.

Hem, J.D., 1985, Study and interpretation of chemical characteristics of natural water: U.S. Geological Survey Water-Supply Paper 2254, $263 \mathrm{p}$.

Hildebrand, S.G., Strand, R.H., and Huckabee, J.W., 1980, Mercury accumulation in fish and invertebrates of the North Fork Holston River, Virginia and Tennessee: Journal of Environmental Quality, v. 9, no. 3, p. 393-400.

Hodson, P.V., Spry, D.J., and Blunt, B.R., 1980, Effects on rainbow trout (Salmo gairdneri) of a chronic exposure to waterbourne selenium: Canadian Journal of Fisheries and Aquatic Science, v. 37, p. 233-240.

Horowitz, A.J., 1991, A primer on sediment-trace element chemistry: Lewis Publishers, Chelsea, Michigan, $136 \mathrm{p}$.

Hunn, J.B., Hamilton, S.J., and Buckler, D.R., 1987, Toxicity of sodium-selenate to rainbow trout fry: Water Resources, v. 21, no. 2, p. 233-238.

Iman, R.L., and Conover, W.J., 1983, A modern approach to statistics: New York, John Wiley and Sons, 497 p.

Irwin, J.H., 1966, Geology and availability of ground water on the Ute Mountain Indian Reservation, Colorado and New Mexico: U.S. Geological Survey Water-Supply Paper 1576-G, $109 \mathrm{p}$.

Johnston, E.P., and Baumann, P.C., 1989, Analysis of fish bile with HPLC-fluorescence to determine environmental exposure to benzo[a]pyrene: Hydrobiologica, v. $188 / 189$, p. $561-566$.

Jones, B.E., 1987, Quality control manual of the U.S. Geological Survey National Water Quality Laboratory: U.S. Geological Survey Open-File Report 87-457, 17 p.

Kahn, E., 1971, Perspective on tuna fish: New England Journal of Medicine, v. 285, p. 49-50.

Lemly, A.D., 1985, Toxicology of selenium in a freshwater reservoir-Implications for environmental hazard evaluation and safety: Ecotoxicology and Environmental Safety, v. 10, p. 314-338. 
1993, Guidelines for evaluating selenium data from aquatic monitoring and assessment studies: Environmental Monitoring and Assessment, v. 28, p. 83-100.

Lemly, A.D., and Smith, G.J., 1987, Aquatic cycling of selenium-Implications for fish and wildlife: U.S. Fish and Wildlife Service, Fish and Wildlife Leaflet 12, 10 p.

McDonald, S.J., Wade, T.L., Brooks, J.M., and McDonald, T.J., 1991, Assessing the exposure of fish to a petroleum spill in Galveston Bay, Texas, in Wrobel, L.C., and Brebbia, C.A., eds., Water pollution-Modeling, measuring, and prediction: London, Elsevier Applied Science, p. 707-718.

Meyer, C.W., and Moretti, Miles, 1988, Fisheries survey of the San Juan River, Utah, 1987: Salt Lake City, Utah Division of Wildlife Resources.

Moore, J.W., and Ramamoorthy, S., 1984, Heavy metals in natural waters-Applied monitoring and impact assessment: New York, Springer-Verlag, 268 p.

Mueller, D.K., DeWeese, L.R., Garner, A.J., and Spruill, T.B., 1991, Reconnaissance investigation of water quality, bottom sediment, and biota associated with irrigation drainage in the middle Arkansas River basin, Colorado and Kansas 1988-89: U.S. Geological Survey Water-Resources Investigations Report 91-4060, $84 \mathrm{p}$.

National Research Council, 1978, An assessment of mercury in the environment: Washington, D.C., National Academy of Sciences, $185 \mathrm{p}$.

National Oceanic and Atmospheric Administration, 1990, Climatological data, annual summary, Colorado, 1990: Asheville, N.C., National Climatic Data Center, v. 95, no. 13, 27 p.

Ogle, R.S., and Knight, A.W., 1989, Effects of elevated foodborne selenium on growth and reproduction of the fathead minnow (Pimephales promelas): Archives of Environmental Contamination and Toxicology, v. 18, no. 6, p. 795-803.

Ohlendorf, H.M., 1993, Marine birds and trace elements in the temperate North Pacific, in Vermeer, K., Briggs, K.T., Morgan, K.H., and Siegal-Causey, D., eds., The status, ecology, and conservation of marine birds of the North Pacific: Ottawa, Wildlife Service Special Publications, p. 232-240.

Ohlendorf, H.M., Hoffman, D.J., Saiki, M.K., and Aldrich, T.W., 1986, Embryonic mortality and abnormalities of aquatic birds-Apparent impacts of selenium from irrigation drainwater: The Science of the Total Environment, v. 52 , no. $1 / 2$, p. $49-63$.

Phillips, G.R., Medvick, P.A., Skaar, D.R., and Knight, D.E., 1987, Factors affecting the mobilization, transport, and bioavailability of mercury in reservoirs of the upper Missouri River basin: U.S. Fish and Wildlife Service Technical Report 10, 64 p.

Platania, S.P., 1990, Biological summary of the 1987 to 1989 New Mexico-Utah ichthyofaunal study of the San Juan
River: Bureau of Reclamation, Salt Lake City, 143 p. plus appendices.

Rand McNally and Company, 1993, Commercial atlas and marketing guide-1993: Rand McNally and Company, p. 276-279.

Rantz, S.E., and others, 1982, Measurement and computation of streamflow-Volume 1. Measurement of stage and discharge: U.S. Geological Survey Water-Supply Paper 2175, $284 \mathrm{p}$.

Ridgley, J.L., Green, M.W., Pierson, C.T., Finch, W.I., and Lupe, R.D., 1978, Summary of the geology and resources of uranium in the San Juan basin and adjacent region, New Mexico, Arizona, Utah, and Colorado: U.S. Geological Survey Open-File Report 78-964, $107 \mathrm{p}$.

Roberts, Bruce, and Moretti, Miles, 1989, Fisheries survey of the San Juan River, Utah, 1988: Salt Lake City, Utah Division of Wildlife Resources.

Saiki, M.K., and May, T.W., 1988, Trace element residues in bluegills and common carp from the lower San Joaquin River, California, and its tributaries: The Science of the Total Environment, v. 74, p. 199-217.

Saiki, M.K., and Palawski, D.U., 1990, Selenium and other elements in juvenile striped bass from the San Joaquin Valley and San Francisco Estuary, California: Archives of Environmental Contamination and Toxicology, v. 19, no. 5, p. 717-730.

Schmitt, C.J., and Brumbaugh, W.G., 1990, National contaminant biomonitoring program-Concentrations of arsenic, cadmium, copper, lead, mercury, selenium, and zinc in U.S. freshwater fish, 1976-1984: Archives of Environmental Contamination and Toxicology, v. 19, no. 5, p. 731-747.

Schmitt, C.J., Zajicek, J.L., and Peterman, P.H., 1990, National contaminant biomonitoring program-Residues of organochlorine chemicals in U.S. freshwater fish, 1976-1984: Archives of Environmental Contamination and Toxicology, v. 19, no. 5, p. 748-781.

Schroeder, R.A., Palawski, D.U., and Skorupa, J.P., 1988, Reconnaissance investigation of water quality, bottom sediment, and biota associated with irrigation drainage in the Tulare Lake bed area, southern San Joaquin Valley, California, 1986-87: U.S. Geological Survey Water-Resources Investigations Report 88-4001, 86 p.

Schultz, R., and Hermanutz, R., 1990, Transfer of toxic concentrations of selenium from parent to progeny in the fathead minnow (Pimephales promelas): Bulletin of Environmental Contamination and Toxicology, v. 45, no. 4, p. 568-573.

Severson, R.C., Stewart, K.C., and Harms, T.F., 1991, Partitioning of elements between two size sediment fractions in samples from nineteen areas of the Western United States: U.S. Geological Survey Open-File Report 91-381, 18 p. 
Shacklette, H.T., and Boerngen, J.G., 1984, Element concentrations in soils and other surficial materials of the conterminous United States: U.S. Geological Survey Professional Paper 1270, $105 \mathrm{p}$.

Sparling, D.W., 1990, Acid precipitation and food qualityInhibition of growth and survival in black ducks and mallards by dietary aluminum, calcium, and phosphorus: Archives of Environmental Contamination and Toxicology, v. 19, no. 3, p. 457-463.

State of Colorado, 1968, Stream fishery studies, Dolores River, federal aid report: Colorado Department of Game, Fish, and Parks Report F-26-R-3, Job 1.

Stephens, D.W., Waddell, Bruce, and Miller, J.B., 1988, Reconnaissance investigation of water quality, bottom sediment, and biota associated with irrigation drainage in the middle Green River basin, Utah, 1986-87: U.S. Geological Survey Water-Resources Investigations Report 88-4011, 70 p.

Stephens, D.W., Waddell, Bruce, Peltz, L.A., and Miller, J.B., 1992, Detailed study of selenium in water, bottom sediment, and biota associated with irrigation drainage in the middle Green River basin, Utah, 1988-90: U.S. Geological Survey Water-Resources Investigations Report 92-4084, 164 p.

Stokes, P.M., and Wren, C.O., 1987, Bioaccumulation of mercury by aquatic biota in hydroelectric reservoirsA review and consideration of mechanisms, in Hutchinson, T.C., and Meema, K.M., eds., Lead, mercury, cadmium, and arsenic in the environment: New York, John Wiley, p. 255-277.

Stone, W.J., Lyford, F.P., Frenzel, P.F., Mizell, N.H., and Padgett, E.T., 1983, Hydrogeology and water resources of the San Juan basin, New Mexico: New Mexico Bureau of Mines and Mineral Resources Hydrologic Report 6, 70 p.

Thatcher, L.L., Janzer, V.J., and Edwards, K.W., 1977, Methods for determination of radioactive substances in water and fluvial sediments: U.S. Geological Survey Techniques of Water-Resources Investigations, book 5 , chap. A5, 95 p.

U.S. Department of the Interior, 1989, Quality of waterColorado River basin: Washington, D.C., Progress Report 14, nine numbered sections.

U.S. Environmental Protection Agency, 1985, Ambient water quality criteria for mercury-1984: U.S. Environmental Protection Agency Report 440/5-84-026, $136 \mathrm{p}$. [Available from the National Technical Information Service, U.S. Department of Commerce, Springfield, VA 22161]

1986, Quality criteria for water, 1986: U.S. Environmental Protection Agency Report EPA-440/5-86-001, 501 p. [Available from the National Technical Information Service, U.S. Department of Commerce, Springfield, VA 22161]
1987, Ambient water quality criteria for selenium1987: Washington, D.C., 39 p.

1988a, Maximum contaminant levels (national interim primary drinking-water regulations): U.S. Code of Federal Regulations, title 40, part 141, subpart B, p. 530-533. [Revised as of July 1,1988 ] 1988b, Secondary maximum contaminant levels (national secondary drinking-water regulations): U.S. Code of Federal Regulations, title 40, part 143, section 143.3, p. 608. [Revised as of July 1,1988 ] 1991, National primary drinking water regulations, Final rule: U.S. Code of Federal Regulations, title 40, chap. 1, part 141, sections 141-1 through 141-6, p. 584-729.

U.S. Fish and Wildlife Service, 1986, Field operations manual for resource contamination assessment: Washington, D.C., variously paged. 1990, Patuxent analytical control facility reference manual: Laurel, Md., U.S. Fish and Wildlife Service.

U.S. Food and Drug Administration, 1978, Mercury distribution and summary-FY78 domestic fish: U.S. Food and Drug Administration Guideline 7408.09.

Utah Department of Health, 1988, Wastewater disposal regulations-Part II, Standards of quality for water of the State: Salt Lake City, p. 41.

Ward, J.R., and Harr, C.A., eds., 1990, Methods for collection and processing of surface-water and bed-material samples for physical and chemical analyses: U.S. Geological Survey Open-File Report 90-140, 71 p.

Weir, J.E., Jr., Maxfield, E.B., and Zimmerman, E.A., 1983, Regional hydrology of the Dolores River basin, eastern Paradox basin, Colorado and Utah: U.S. Geological Survey Water-Resources Investigations Report 83-4217, 53 p.

Wershaw, R.L., Fishman, M.J., Grabbe, R.R., and Lowe, L.E., eds., 1987, Methods for the determination of organic substances in water and fluvial sediments: U.S. Geological Survey Techniques of WaterResources Investigations, book 5, chap. A3, 80 p.

White, D.H., Mitchell, C.A., Kennedy, H.D., Krynitsky, A.J., and Ribick, M.A., 1983, Elevated DDE and toxaphene residues in fishes and birds reflect local contamination in the lower Rio Grande Valley, Texas: The Southwestern Naturalist, v. 28, no. 3, p. 325-333.

Whitfield, M.S., Jr., Thordarson, William, Oatfield, W.J., Zimmerman, E.A., and Rueger, B.F., 1983, Regional hydrology of the Blanding-Durango area, southern Paradox basin, Utah and Colorado: U.S. Geological Survey Water-Resources Investigations Report 83-4218, $88 \mathrm{p}$.

Wiener, J.G., Martini, R.E., Sheffy, T.B., and Glass, G.E., 1990 , Factors influencing mercury concentration in walleyes in northern Wisconsin lakes: Transactions of the American Fisheries Society, v. 119, no. 5, p. 862-870. 


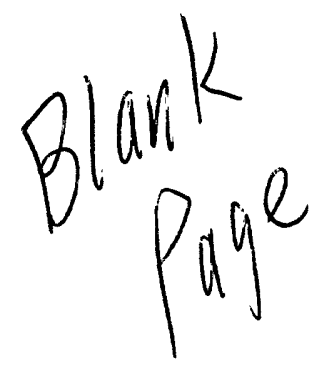

64 


\section{SUPPLEMENTAL DATA}


Table 22. Physical properties and inorganic constituent concentrations in water samples collected in the Dolores Project area from March through November, 1990

$\left[\mathrm{ft}^{3} / \mathrm{s}\right.$, cubic feet per second; $\mu \mathrm{S} / \mathrm{cm}$, microsiemens per centimeter at 25 degrees Celsius; ${ }^{\circ} \mathrm{C}$, degrees Celsius; MVIC, Montezuma Valley lrrigation Company; $\mathrm{mg} / \mathrm{L}$, milligrams per liter; $\mu \mathrm{g} / \mathrm{L}$, micrograms per liter; <, less than reporting limit; E, estimated;,-- no data]

\begin{tabular}{|c|c|c|c|c|c|c|c|}
\hline $\begin{array}{c}\text { Site } \\
\text { number } \\
\text { (figs. 1, 2) }\end{array}$ & Site name & Date & Time & $\begin{array}{c}\text { Stream } \\
\text { discharga } \\
\left(\mathrm{ft}^{\mathbf{3}} / \mathrm{s}\right)\end{array}$ & $\begin{array}{c}\text { Specific } \\
\text { conduct- } \\
\text { ance } \\
(\mu \mathrm{S} / \mathrm{cm})\end{array}$ & $\begin{array}{c}\text { pH } \\
\text { (standard } \\
\text { units) }\end{array}$ & $\begin{array}{l}\text { Water } \\
\text { temp- } \\
\text { erature } \\
\left({ }^{\circ} \mathrm{C}\right)\end{array}$ \\
\hline \multicolumn{8}{|c|}{ MVIC AREA } \\
\hline \multirow[t]{3}{*}{ ME1 } & \multirow{3}{*}{$\begin{array}{l}\text { Mc Elmo Creek at Highway } 160 \text { near } \\
\text { Cortez }\end{array}$} & $03-27-90$ & 1100 & 0.09 & 6,380 & 8.3 & 10.5 \\
\hline & & $07-16-90$ & 1930 & 3.1 & 1,430 & 7.5 & 20.0 \\
\hline & & $11-14-90$ & 1520 & E.02 & 6,210 & 8.2 & 6.5 \\
\hline \multirow[t]{4}{*}{ ME2 } & \multirow{4}{*}{$\begin{array}{l}\text { Mc Elmo Creek downstream from } \\
\text { Alkali Canyon }\end{array}$} & $03-27-90$ & 1630 & 19 & 3,490 & 8.8 & 11.5 \\
\hline & & $07-16-90$ & 1700 & 131 & 1,690 & 8.2 & 22.0 \\
\hline & & $07-19-90$ & 1430 & 78 & 1,680 & 8.4 & 23.0 \\
\hline & & $11-14-90$ & 1400 & 42 & 2,530 & 8.5 & 6.0 \\
\hline \multirow[t]{3}{*}{ ME3 } & \multirow{3}{*}{$\begin{array}{l}\text { Mc Elmo Creek upstream from } \\
\text { Yellow Jacket Canyon }\end{array}$} & $03-27-90$ & 1450 & 21 & 3,340 & 8.5 & 15.0 \\
\hline & & $07-16-90$ & 1500 & 272 & 2,000 & 7.6 & 19.0 \\
\hline & & $11-14-90$ & 1130 & 56 & 2,570 & 8.4 & 6.0 \\
\hline \multirow[t]{3}{*}{ ME4 } & \multirow{3}{*}{$\begin{array}{l}\text { Mc Elmo Creek downstream from } \\
\text { Yellow Jacket Canyon }\end{array}$} & $03-27-90$ & 1230 & 26 & 3,180 & 8.5 & 13.0 \\
\hline & & $07-16-90$ & 1240 & E300 & 2,490 & 7.7 & 20.0 \\
\hline & & $11-14-90$ & 0830 & 67 & 2,360 & 8.3 & 4.0 \\
\hline \multirow[t]{2}{*}{ DT } & \multirow[t]{2}{*}{ Dolores Tunnel outflow } & $05-15-90$ & 0900 & 209 & 293 & 8.3 & 8.0 \\
\hline & & $08-14-90$ & 0830 & 48 & 264 & 7.7 & 12.5 \\
\hline \multirow[t]{2}{*}{ GD } & \multirow[t]{2}{*}{ Great Cut Dike outflow } & $05-15-90$ & 1030 & 108 & 297 & 8.3 & 9.0 \\
\hline & & $08-14-90$ & 0910 & 159 & 265 & 8.2 & 18.0 \\
\hline \multirow[t]{4}{*}{ SU } & \multirow{4}{*}{$\begin{array}{r}\text { Summit Reservoir - } \\
\text { near-surface sample } \\
\text { near-bottom sample } \\
\text { near-surface sample } \\
\text { near-bottom sample }\end{array}$} & $04-17-90$ & 1015 & -- & 190 & 8.3 & 12.0 \\
\hline & & $04-17-90$ & 1020 & -- & 141 & 8.0 & 7.0 \\
\hline & & $11-08-90$ & 1015 & -- & 126 & 9.0 & 4.5 \\
\hline & & $11-08-90$ & 1020 & -- & 126 & 8.6 & 4.5 \\
\hline \multirow[t]{4}{*}{ PU } & - near-surface sample & $04-17-90$ & 0910 & -- & 634 & 8.7 & 12.5 \\
\hline & near-bottom sample & $04-17-90$ & 0915 & -- & 626 & 8.9 & 12.5 \\
\hline & near-surface sample & $11-08-90$ & 1130 & -- & 478 & 9.0 & 5.0 \\
\hline & near-bottom sample & $11-08-90$ & 1135 & - & 482 & 9.0 & 5.0 \\
\hline
\end{tabular}


Table 22. Physical properties and inorganic constituent concentrations in water samples collected in the Dolores Project area from March through November, 1990--Continued

\begin{tabular}{|c|c|c|c|c|c|c|c|c|c|c|c|}
\hline $\begin{array}{c}\text { Site } \\
\text { number } \\
\text { (figs. 1, } \\
\text { 2) }\end{array}$ & Date & $\begin{array}{c}\text { Dis- } \\
\text { solved } \\
\text { oxygen } \\
\text { (mg/L) }\end{array}$ & $\begin{array}{c}\text { Hard- } \\
\text { ness, } \\
\text { total } \\
\text { (mg/L } \\
\text { as } \\
\left.\mathrm{CaCO}_{3}\right)\end{array}$ & $\begin{array}{l}\text { Calcium, } \\
\text { dis- } \\
\text { solved } \\
\text { (mg/l } \\
\text { as Ca) }\end{array}$ & $\begin{array}{l}\text { Magne- } \\
\text { sium, } \\
\text { dis- } \\
\text { solved } \\
\text { (mg/L } \\
\text { as } \mathrm{Mg})\end{array}$ & $\begin{array}{l}\text { Sodium, } \\
\text { dis- } \\
\text { solved } \\
\text { (mg/L } \\
\text { as } \mathrm{Na} \text { ) }\end{array}$ & $\begin{array}{l}\text { Sodium } \\
\text { adsorp- } \\
\text { tion } \\
\text { ratio }\end{array}$ & $\begin{array}{l}\text { Potas- } \\
\text { sium, } \\
\text { dis- } \\
\text { solved } \\
\text { (mg/L } \\
\text { as K) }\end{array}$ & $\begin{array}{l}\text { Sulfate, } \\
\text { dis- } \\
\text { solved } \\
\text { (mg/l } \\
\text { as SO }\end{array}$ & $\begin{array}{l}\text { Chlo- } \\
\text { ride, } \\
\text { dis- } \\
\text { solved } \\
\text { (mg/L } \\
\text { as Cl) }\end{array}$ & $\begin{array}{c}\text { Alka- } \\
\text { linity, } \\
\text { (mg/L } \\
\text { as } \\
\mathrm{CaCO}_{3} \text { ) }\end{array}$ \\
\hline \multicolumn{12}{|c|}{ MVIC AREA-Continued } \\
\hline \multirow{3}{*}{ ME1 } & $03-27-90$ & 9.9 & 3,000 & 380 & 490 & 680 & 5 & 5.0 & 4,300 & 93 & 270 \\
\hline & $07-16-90$ & 6.6 & 570 & 130 & 59 & 95 & 2 & 6.4 & 670 & 15 & 85 \\
\hline & $11-14-90$ & 11.0 & 2,600 & 380 & 400 & 680 & 6 & 5.0 & 3,800 & 110 & 276 \\
\hline \multirow[t]{4}{*}{ ME2 } & $03-27-90$ & 10.1 & 1,800 & 340 & 230 & 250 & 3 & 5.5 & 1,700 & 47 & 238 \\
\hline & $07-16-90$ & 7.1 & 820 & 200 & 78 & 87 & 1 & 5.9 & 830 & 17 & 196 \\
\hline & $07-19-90$ & 6.8 & 860 & 200 & 87 & 82 & 1 & 4.0 & 700 & 15 & 232 \\
\hline & $11-14-90$ & 11.1 & 1,400 & 300 & 150 & 140 & 2 & 4.2 & 1,300 & 27 & 241 \\
\hline \multirow[t]{3}{*}{ ME3 } & $03-27-90$ & 9.1 & 1,700 & 310 & 220 & 240 & 3 & 6.0 & 1,900 & 33 & 208 \\
\hline & $07-16-90$ & 7.0 & 890 & 220 & 82 & 120 & 2 & 8.6 & 1,100 & 18 & 150 \\
\hline & $11-14-90$ & 10.9 & 1,300 & 290 & 150 & 150 & 2 & 4.6 & 1,300 & 29 & 252 \\
\hline \multirow[t]{3}{*}{ ME4 } & $03-27-90$ & 9.3 & 1,600 & 290 & 220 & 240 & 3 & 6.0 & 1,600 & 46 & 213 \\
\hline & $07-16-90$ & 6.8 & 1,100 & 250 & 110 & 170 & 2 & 9.0 & 1,300 & 33 & 189 \\
\hline & $11-14-90$ & 11.1 & 1,300 & 270 & 150 & 140 & 2 & 4.4 & 1,200 & 29 & 252 \\
\hline \multirow[t]{2}{*}{ DT } & $05-15-90$ & -- & 140 & 44 & 7.1 & 7.7 & .3 & 2.6 & 31 & 5.7 & 108 \\
\hline & $08-14-90$ & -- & 130 & 41 & 6.4 & 7.1 & .3 & 1.6 & 30 & 7.3 & 100 \\
\hline \multirow[t]{2}{*}{ GD } & $05-15-90$ & 9.4 & 140 & 44 & 7.0 & 7.6 & .3 & 1.6 & 30 & 8.8 & 110 \\
\hline & $08-14-90$ & -- & 130 & 40 & 6.3 & 6.9 & .3 & 1.6 & 24 & 8.3 & 111 \\
\hline \multirow[t]{4}{*}{ SU } & $04-17-90$ & 8.3 & 79 & 24 & 4.6 & 5.9 & .3 & 1.1 & 32 & .6 & 55 \\
\hline & $04-17-90$ & 8.4 & 52 & 15 & 3.5 & 4.8 & .3 & 1.0 & 25 & .6 & 41 \\
\hline & $11-08-90$ & 9.0 & 57 & 18 & 2.9 & 3.8 & .2 & .50 & 16 & 1.2 & 49 \\
\hline & $11-08-90$ & 9.0 & 60 & 19 & 3.0 & 3.9 & .2 & .60 & 16 & 1.0 & 49 \\
\hline \multirow[t]{4}{*}{ PU } & $04-17-90$ & 9.1 & 240 & 60 & 23 & 39 & 1 & 1.8 & 190 & 6.8 & 109 \\
\hline & $04-17-90$ & 9.2 & 240 & 60 & 23 & 39 & 1 & 1.9 & 190 & 6.8 & 109 \\
\hline & $11-08-90$ & 8.9 & 190 & 49 & 16 & 28 & .9 & 1.7 & 120 & 6.3 & 109 \\
\hline & $11-08-90$ & 9.1 & 190 & 49 & 16 & 28 & .9 & 1.8 & 120 & 7.5 & 110 \\
\hline
\end{tabular}


Table 22. Physical properties and inorganic constituent concentrations in water samples collected in the Dolores Project area from March through November, 1990--Continued

\begin{tabular}{|c|c|c|c|c|c|c|c|c|c|c|c|}
\hline $\begin{array}{l}\text { Site } \\
\text { number } \\
\text { (figs. 1, } \\
\text { 2) }\end{array}$ & Date & $\begin{array}{l}\text { Fluo- } \\
\text { rlde, } \\
\text { dis- } \\
\text { solved } \\
\text { (mg/L } \\
\text { as F) }\end{array}$ & $\begin{array}{c}\text { Silica, } \\
\text { dis- } \\
\text { solved } \\
\text { (mghl } \\
\text { as } \\
\text { sion) }\end{array}$ & $\begin{array}{l}\text { Dis- } \\
\text { solved } \\
\text { solids } \\
\text { (mg/L) }\end{array}$ & $\begin{array}{l}\text { Dls- } \\
\text { solved } \\
\text { solids } \\
\text { (tons } \\
\text { per day) }\end{array}$ & $\begin{array}{l}\text { Nitrogen, } \\
\text { Nitrite } \\
\text { dis- } \\
\text { solved } \\
\text { (mg/L as } \\
\text { N) }\end{array}$ & $\begin{array}{l}\text { Nitrogen, } \\
\mathrm{NO}_{2}+\mathrm{NO}_{3} \\
\text { dlssolved } \\
\text { (mg/L as } \\
\mathrm{N} \text { ) }\end{array}$ & $\begin{array}{l}\text { Nitrogen, } \\
\text { ammonia } \\
\text { dis- } \\
\text { solved } \\
\text { (mg/L as } \\
\mathrm{N})\end{array}$ & $\begin{array}{l}\text { Ortho- } \\
\text { phos- } \\
\text { phorus, } \\
\text { dis- } \\
\text { solved } \\
\text { (mgll } \\
\text { as P) }\end{array}$ & $\begin{array}{c}\text { Arsenlc, } \\
\text { dis- } \\
\text { solved } \\
(\mu g / \text { as } \\
\text { As) }\end{array}$ & $\begin{array}{c}\text { Boron, } \\
\text { dis- } \\
\text { solved } \\
(\mu g / L \\
\text { as B) }\end{array}$ \\
\hline \multicolumn{12}{|c|}{ MVIC AREA-Continued } \\
\hline \multirow[t]{3}{*}{ ME1 } & $03-27-90$ & -- & -- & 6,110 & 1.48 & -- & $<0.1$ & -- & -- & $<1$ & 150 \\
\hline & $07-16-90$ & -- & 5.1 & 1,030 & 8.62 & -- & .4 & -- & - & 1 & 60 \\
\hline & $11-14-90$ & 0.4 & 5.7 & 5,550 & E.30 & 0.01 & $<.1$ & 0.03 & $<0.01$ & $<1$ & 150 \\
\hline \multirow[t]{4}{*}{ ME2 } & $03-27-90$ & -- & -- & 2,740 & 143 & -- & 4.7 & -- & -- & $<1$ & 260 \\
\hline & $07-16-90$ & - & 12 & 1,350 & 477 & -- & .5 & -- & -- & 1 & 120 \\
\hline & $07-19-90$ & -- & 12 & 1,240 & 261 & -- & .9 & -- & -- & 1 & 140 \\
\hline & $11-14-90$ & .3 & 10 & 2,090 & 237 & .01 & 2.0 & .06 & .10 & $<1$ & 170 \\
\hline \multirow[t]{3}{*}{ ME3 } & $03-27-90$ & -- & -- & 2,840 & 161 & -- & 1.8 & -- & -- & $<1$ & 230 \\
\hline & $07-16-90$ & -- & 7.4 & 1,650 & 1,210 & .- & 1.1 & -. & -- & 1 & 110 \\
\hline & $11-14-90$ & .1 & 9.5 & 2,090 & 316 & $<.01$ & 1.2 & .01 & .01 & $<1$ & 180 \\
\hline \multirow[t]{3}{*}{ ME4 } & $03-27-90$ & -- & - & 2,540 & 178 & -- & 1.8 & -- & -- & $<1$ & 220 \\
\hline & $07-16-90$ & -- & 8.3 & 2,000 & 1,620 & -- & 1.8 & -- & -- & 1 & 150 \\
\hline & $11-14-90$ & .3 & 9.7 & 1,960 & 354 & $<.01$ & 1.2 & .01 & .01 & $<1$ & 170 \\
\hline \multirow[t]{2}{*}{ DT } & $05-15-90$ & - & -- & 163 & 91.9 & -- & $<.1$ & -- & -- & $<1$ & 20 \\
\hline & $08-14-90$ & - & 4.0 & 157 & 20.4 & - & $<.1$ & -- & -- & 1 & 10 \\
\hline \multirow[t]{2}{*}{ GD } & $05-15-90$ & - & -- & 165 & 48.1 & -- & $<.1$ & -- & -- & $<1$ & 20 \\
\hline & $08-14-90$ & -- & 4.5 & 158 & 67.9 & -- & $<.1$ & -- & -- & 1 & $<10$ \\
\hline \multirow[t]{4}{*}{ SU } & $04-17-90$ & -- & -- & 101 & -- & -- & $<.1$ & -- & -- & $<1$ & $<10$ \\
\hline & $04-17-90$ & -- & -- & 74 & -- & -- & $<.1$ & -- & -- & $<1$ & $<10$ \\
\hline & $11-08-90$ & $<.1$ & 3.6 & 75 & -- & $<.01$ & $<.1$ & $<.01$ & $<.01$ & 1 & 10 \\
\hline & $11-08-90$ & $<.1$ & 3.6 & 76 & -- & $<.01$ & $<.1$ & $<.01$ & $<.01$ & $<1$ & $<10$ \\
\hline \multirow[t]{4}{*}{ PU } & $04-17-90$ & -- & -- & 386 & - & -- & $<.1$ & -- & -- & 1 & 20 \\
\hline & $04-17-90$ & -- & -- & 386 & -- & -- & $<.1$ & -- & -- & 1 & 20 \\
\hline & $11-08-90$ & .1 & .5 & 287 & -- & $<.01$ & $<.1$ & $<.01$ & $<.01$ & 1 & 20 \\
\hline & $11-08-90$ & .1 & .5 & 289 & -- & $<.01$ & $<.1$ & .05 & $<.01$ & 1 & 20 \\
\hline
\end{tabular}

68 Reconnaissance Investigation of Water Quality, Bottom Sediment, and Biota Associated with Irrigation Drainage in the Dolores Project Area, Southwestern Colorado and Southeastern Utah, 1990-91 
Table 22. Physical properties and inorganic constituent concentrations in water samples collected in the Dolores Project area from March through November, 1990--Continued

\begin{tabular}{|c|c|c|c|c|c|c|c|c|c|c|c|}
\hline $\begin{array}{c}\text { Shte } \\
\text { number } \\
\text { (figs. 1, } \\
\text { 2) }\end{array}$ & Date & $\begin{array}{l}\text { Cad- } \\
\text { mium, } \\
\text { dis- } \\
\text { solved } \\
(\mu g / L \\
\text { as Cd) }\end{array}$ & $\begin{array}{l}\text { Chro- } \\
\text { mium, } \\
\text { dis- } \\
\text { soived } \\
(\mu g / L \\
\text { as Cr) }\end{array}$ & $\begin{array}{l}\text { Copper, } \\
\text { dis- } \\
\text { solved } \\
\mu \text { g/L as } \\
\text { Cu) }\end{array}$ & $\begin{array}{l}\text { Load, } \\
\text { dis- } \\
\text { solved } \\
(\mu \mathrm{g} / \mathrm{L} \\
\text { as Pb) }\end{array}$ & $\begin{array}{l}\text { Mer- } \\
\text { cury, } \\
\text { dis- } \\
\text { solved } \\
(\mu g / L \\
\text { as Hg) }\end{array}$ & $\begin{array}{l}\text { Moiyb- } \\
\text { denum, } \\
\text { dis- } \\
\text { solved } \\
(\mu g / \mathrm{L} \\
\text { as Mo) }\end{array}$ & $\begin{array}{l}\text { Seie- } \\
\text { nium, } \\
\text { dis- } \\
\text { solved } \\
(\mu g / L \\
\text { as Se) }\end{array}$ & $\begin{array}{l}\text { Vana- } \\
\text { dium, } \\
\text { dis- } \\
\text { soived } \\
(\mu g / L \\
\text { as V) }\end{array}$ & $\begin{array}{l}\text { Zinc, } \\
\text { dis- } \\
\text { solved } \\
(\mu g / \\
\text { as Zn) }\end{array}$ & $\begin{array}{c}\text { Ura- } \\
\text { nium, } \\
\text { naturai } \\
\text { totai } \\
(\mu g / \text { } \\
\text { as U) }\end{array}$ \\
\hline \multicolumn{12}{|c|}{ MVIC AREA-Continued } \\
\hline \multirow[t]{3}{*}{ ME1 } & $03-27-90$ & $<1$ & $<1$ & 4 & $<1$ & $<0.1$ & 7 & 2 & 1 & 10 & 19 \\
\hline & $07-16-90$ & 2 & 2 & 3 & $<1$ & $<.1$ & 5 & 2 & 5 & 8 & 1.5 \\
\hline & $11-14-90$ & $<1$ & $<1$ & 1 & $<1$ & $<.1$ & 4 & $<1$ & 4 & $<10$ & 25 \\
\hline \multirow[t]{4}{*}{ ME2 } & $03-27-90$ & $<1$ & 1 & 2 & $<1$ & $<.1$ & 2 & 8 & $<1$ & $<10$ & 11 \\
\hline & $07-16-90$ & 2 & $<1$ & 5 & $<1$ & $<.1$ & 4 & 2 & 6 & 4 & 6.6 \\
\hline & $07-19-90$ & $<1$ & $<1$ & 1 & $<1$ & .1 & 1 & 2 & 6 & $<3$ & 3.4 \\
\hline & $11-14-90$ & $<1$ & 1 & 1 & $<1$ & $<.1$ & $<1$ & 4 & 1 & $<10$ & 7.3 \\
\hline \multirow[t]{3}{*}{ ME3 } & $03-27-90$ & $<1$ & $<1$ & 2 & $<1$ & $<.1$ & 3 & 6 & $<1$ & $<10$ & 8.4 \\
\hline & $07-16-90$ & $<1$ & 3 & 2 & 1 & $<.1$ & 13 & 6 & 6 & $<10$ & 6.9 \\
\hline & $11-14-90$ & 1 & $<1$ & 1 & $<1$ & $<.1$ & 3 & 3 & 1 & $<10$ & 7.8 \\
\hline \multirow[t]{3}{*}{ ME4 } & $03-27-90$ & $<1$ & $<1$ & 2 & $<1$ & $<.1$ & 4 & 6 & $<1$ & $<10$ & 8.3 \\
\hline & $07-16-90$ & $<1$ & 1 & 10 & $<1$ & $<.1$ & 16 & 9 & 8 & 10 & 9.0 \\
\hline & $11-14-90$ & 3 & $<1$ & 1 & $<1$ & $<.1$ & 1 & 3 & 1 & $<10$ & 6.5 \\
\hline \multirow[t]{2}{*}{ DT } & $05-15-90$ & $<1$ & $<1$ & 4 & 1 & $<.1$ & 2 & $<1$ & 2 & 11 & $<1.0$ \\
\hline & $08-14-90$ & $<1$ & $<1$ & 1 & $<1$ & $<.1$ & $<1$ & $<1$ & 2 & 10 & 2.4 \\
\hline \multirow[t]{2}{*}{ GD } & $05-15-90$ & $<1$ & $<1$ & 4 & 1 & $<.1$ & 2 & $<1$ & 2 & 9 & $<1.0$ \\
\hline & $08-14-90$ & $<1$ & $<1$ & 2 & $<1$ & $<.1$ & $<1$ & $<1$ & 2 & 16 & $<1.0$ \\
\hline \multirow[t]{4}{*}{ SU } & $04-17-90$ & $<1$ & $<1$ & 3 & $<1$ & $<.1$ & $<1$ & $<1$ & $<1$ & $<3$ & $<1.0$ \\
\hline & $04-17-90$ & $<1$ & $<1$ & 2 & $<1$ & $<.1$ & $<1$ & $<1$ & 1 & 11 & $<1.0$ \\
\hline & $11-08-90$ & 2 & $<1$ & 1 & $<1$ & $<.1$ & $<1$ & $<1$ & 2 & 4 & $<1.0$ \\
\hline & $11-08-90$ & $<1$ & $<1$ & 2 & $<1$ & $<.1$ & $<1$ & $<1$ & 2 & 4 & $<1.0$ \\
\hline \multirow[t]{4}{*}{ PU } & $04-17-90$ & $<1$ & $<1$ & 2 & $<1$ & .1 & 1 & $<1$ & $<1$ & $<3$ & 3.4 \\
\hline & $04-17-90$ & $<1$ & $<1$ & 3 & $<1$ & .1 & $<1$ & $<1$ & $<1$ & 3 & 1.2 \\
\hline & $11-08-90$ & 2 & $<1$ & 2 & $<1$ & $<.1$ & $<1$ & $<1$ & 2 & 4 & $<1.0$ \\
\hline & $11-08-90$ & 4 & $<1$ & 5 & $<1$ & $<.1$ & $<1$ & 1 & 2 & 6 & $<1.0$ \\
\hline
\end{tabular}


Table 22. Physical properties and inorganic constituent concentrations in water samples collected in the Dolores Project area from March through November, 1990--Continued

\begin{tabular}{|c|c|c|c|c|c|c|c|}
\hline $\begin{array}{c}\text { Site } \\
\text { number } \\
\text { (figs. 1, 2) }\end{array}$ & Site name & Date & Time & $\begin{array}{c}\text { Stream } \\
\text { discharge } \\
\left(\mathrm{ft}^{3} / \mathrm{s}\right)\end{array}$ & $\begin{array}{c}\text { Speclific } \\
\text { conduct- } \\
\text { ance } \\
(\mu \mathrm{S} / \mathrm{cm})\end{array}$ & $\begin{array}{c}\text { pH } \\
\text { (standard } \\
\text { units) }\end{array}$ & $\begin{array}{c}\text { Water } \\
\text { temp- } \\
\text { erature } \\
\left({ }^{\circ} \mathrm{C}\right)\end{array}$ \\
\hline \multicolumn{8}{|c|}{ MVIC AREA-Continued } \\
\hline \multirow[t]{4}{*}{ TT } & Totten Reservoir - near-surface sample & $04-17-90$ & 1210 & -- & 1,020 & 8.2 & 13.5 \\
\hline & near-bottom sample & $04-17-90$ & 1215 & -- & 1,030 & 8.2 & 13.5 \\
\hline & near-surface sample & $11-08-90$ & 1250 & - & 758 & 8.2 & 7.5 \\
\hline & near-bottom sample & $11-08-90$ & 1255 & - & 757 & 8.3 & 7.5 \\
\hline \multirow[t]{3}{*}{ SD } & Simon Draw downstream from & $03-28-90$ & 1340 & .76 & 3,360 & 8.1 & 14.0 \\
\hline & Cash Canyon & $07-18-90$ & 1430 & .64 & 2,710 & 7.9 & 23.5 \\
\hline & & $11-08-90$ & 1500 & .65 & 2,790 & 8.1 & 8.0 \\
\hline \multirow[t]{3}{*}{ HD1 } & Hartman Draw near Lebanon & $03-28-90$ & 1230 & 2.4 & 2,570 & 8.0 & 12.0 \\
\hline & & $07-18-90$ & 1230 & 4.8 & 1,910 & 8.0 & 20.5 \\
\hline & & $11-13-90$ & 1400 & 6.5 & 1,880 & 8.1 & 7.0 \\
\hline \multirow[t]{3}{*}{ HD2 } & Hartman Draw near mouth, at Cortez & $03-28-90$ & 0830 & 4.4 & 2,820 & 8.2 & 6.0 \\
\hline & & $07-18-90$ & 0840 & 27 & 1,770 & 8.2 & 17.5 \\
\hline & & $11-13-90$ & 1500 & 15 & 2,260 & 8.4 & 6.5 \\
\hline \multirow[t]{3}{*}{$\mathbf{A K}$} & Alkali Canyon downstream from & $03-28-90$ & 1000 & 4.3 & 2,460 & 8.1 & 7.5 \\
\hline & Narraguinnep Canyon & $07-18-90$ & 1030 & 23 & 1,410 & 8.2 & 18.0 \\
\hline & & $11-09-90$ & 0800 & 13 & 2,220 & 8.3 & 3.0 \\
\hline \multirow[t]{3}{*}{ DD } & Dawson Draw near Lewis & $04-11-90$ & 0730 & 1.9 & 2,090 & 8.1 & 6.5 \\
\hline & & $07-19-90$ & 1140 & 15 & 882 & 8.2 & 21.5 \\
\hline & & $11-09-90$ & 0900 & 4.5 & 1,400 & 8.1 & 2.5 \\
\hline \multirow[t]{3}{*}{ YJ2 } & Yellow Jacket Canyon at mouth & $03-27-90$ & 1400 & 2.5 & 1,590 & 8.4 & 17.0 \\
\hline & & $07-16-90$ & 1330 & 21 & 936 & 8.5 & 27.0 \\
\hline & & $11-14-90$ & 1000 & 8.3 & 1,200 & 8.4 & 4.0 \\
\hline \multirow[t]{3}{*}{ NW } & Navajo Wash near Towaoc & $03-28-90$ & 0730 & .87 & 6,880 & 8.4 & 6.0 \\
\hline & & $07-18-90$ & 0730 & 19 & 1,380 & 8.1 & 18.0 \\
\hline & & $11-06-90$ & 1630 & 9.0 & 2,390 & 8.1 & 6.0 \\
\hline
\end{tabular}


Table 22. Physical properties and inorganic constituent concentrations in water samples collected in the Dolores Project area from March through November, 1990--Continued

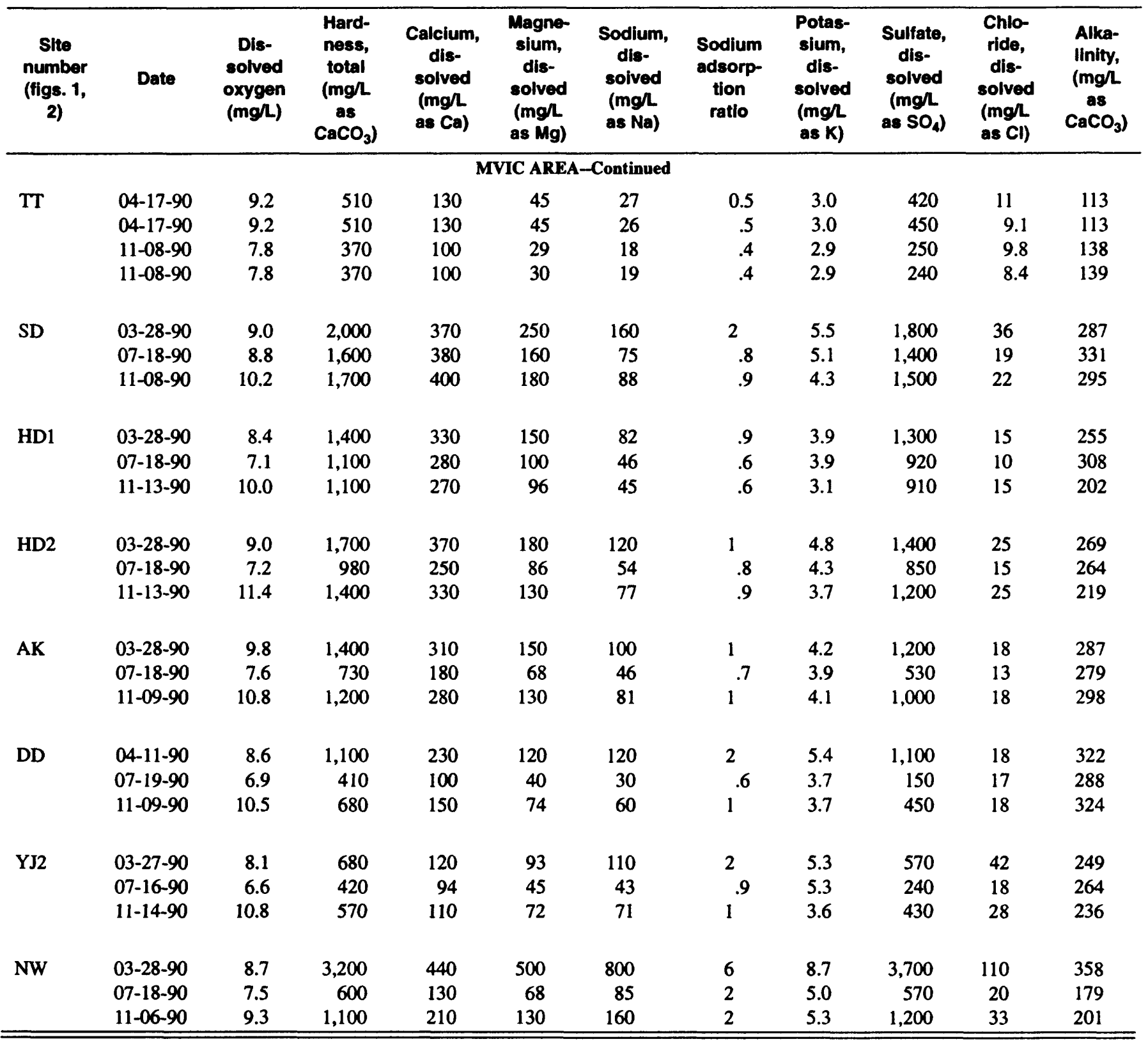


Table 22. Physical properties and inorganic constituent concentrations in water samples collected in the Dolores Project area from March through November, 1990--Continued

\begin{tabular}{|c|c|c|c|c|c|c|c|c|c|c|c|}
\hline $\begin{array}{c}\text { Site } \\
\text { number } \\
\text { (figs. 1, } \\
\text { 2) }\end{array}$ & Date & $\begin{array}{l}\text { Fluo- } \\
\text { ride, } \\
\text { dis- } \\
\text { solved } \\
\text { (mgh } \\
\text { as F) }\end{array}$ & $\begin{array}{c}\text { Sillica, } \\
\text { dis- } \\
\text { solved } \\
(\mathrm{mgl} \text {. } \\
\text { as } \\
\left.\mathrm{siO}_{2}\right)\end{array}$ & $\begin{array}{l}\text { Dis- } \\
\text { solved } \\
\text { sollds } \\
\text { (mg/L) }\end{array}$ & $\begin{array}{l}\text { Dis- } \\
\text { solved } \\
\text { sollds } \\
\text { (tons } \\
\text { per } \\
\text { day) }\end{array}$ & $\begin{array}{l}\text { Nitrogen, } \\
\text { Nitrite } \\
\text { dis- } \\
\text { solved } \\
\text { (mg/L as } \\
\text { N }\end{array}$ & $\begin{array}{l}\text { Nitrogen, } \\
\mathrm{NO}_{2}+\mathrm{NO}_{3} \\
\text { dissolved } \\
\text { (mg/L as } \\
\mathrm{N} \text { ) }\end{array}$ & $\begin{array}{l}\text { Nitrogen, } \\
\text { ammonla } \\
\text { dls- } \\
\text { solved } \\
\text { (mg/l as } \\
\mathrm{N} \text { ) }\end{array}$ & $\begin{array}{l}\text { Ortho- } \\
\text { phos- } \\
\text { phorus, } \\
\text { dis- } \\
\text { solved } \\
\text { (mg/L } \\
\text { as P) }\end{array}$ & $\begin{array}{l}\text { Arsenic, } \\
\text { dis- } \\
\text { solved } \\
(\mu g / \text { as } \\
\text { As) }\end{array}$ & $\begin{array}{c}\text { Boron, } \\
\text { dls- } \\
\text { solved } \\
(\mu g / \text {. } \\
\text { as B) }\end{array}$ \\
\hline \multicolumn{12}{|c|}{ MVIC AREA-Continned } \\
\hline \multirow[t]{4}{*}{ TT } & $04-17-90$ & -- & - & 704 & -- & -- & $<0.1$ & -- & -- & 1 & 70 \\
\hline & $04-17-90$ & -- & -- & 731 & -- & -- & $<.1$ & -- & -- & $<1$ & 70 \\
\hline & $11-08-90$ & .3 & 6.3 & 499 & -- & $<0.01$ & $<.1$ & 0.01 & $<0.01$ & 1 & 60 \\
\hline & $11-08-90$ & .3 & 6.5 & 491 & - & $<.01$ & $<.1$ & .02 & $<.01$ & $<1$ & 60 \\
\hline \multirow[t]{3}{*}{ SD } & $03-28-90$ & -- & - & 2,790 & 5.73 & - & $<.1$ & -- & -- & $<1$ & 130 \\
\hline & $07-18-90$ & - & 11 & 2,250 & 3.89 & -- & $<.1$ & -- & -. & $<1$ & 170 \\
\hline & $11-08-90$ & .2 & 10 & 2,380 & 4.18 & $<.01$ & $<.1$ & .03 & $<.01$ & $<1$ & 140 \\
\hline \multirow[t]{3}{*}{ HD1 } & $03-28-90$ & -- & -- & 2,030 & 13.2 & -- & $<.1$ & -- & -- & $<1$ & 110 \\
\hline & $07-18-90$ & -- & 14 & 1,560 & 20.2 & -- & $<.1$ & -- & -- & 1 & 120 \\
\hline & $11-13-90$ & 0.2 & 9.9 & 1,470 & 25.8 & $<.01$ & $<.1$ & .02 & .01 & $<1$ & 80 \\
\hline \multirow[t]{3}{*}{ HD2 } & $03-28-90$ & - & -- & 2,270 & 27.0 & - & 1.7 & - & -. & 1 & 160 \\
\hline & $07-18-90$ & - & 13 & 1,430 & 102 & - & .2 & -- & -- & 1 & 140 \\
\hline & $11-13-90$ & .3 & 9.5 & 1,910 & 79.9 & $<.01$ & .4 & .05 & .08 & $<1$ & 130 \\
\hline \multirow[t]{3}{*}{ AK } & $03-28-90$ & -- & - & 1,950 & 22.6 & -- & $<.1$ & -- & -- & $<1$ & 130 \\
\hline & $07-18-90$ & -- & 16 & 1,020 & 64.2 & -- & $<.1$ & -- & -- & 1 & 110 \\
\hline & $11-09-90$ & .3 & 14 & 1,710 & 62.3 & $<.01$ & $<.1$ & .01 & $<.01$ & $<1$ & 130 \\
\hline \multirow[t]{3}{*}{ DD } & 04-11-90 & - & - & 1,790 & 9.18 & - & $<.1$ & -- & - & 1 & 100 \\
\hline & $07-19-90$ & -- & 18 & 531 & 22.1 & -- & $<.1$ & -- & -- & 1 & 80 \\
\hline & $11-09-90$ & .3 & 15 & 965 & 11.7 & $<.01$ & $<.1$ & $<.01$ & .03 & 1 & 80 \\
\hline \multirow[t]{3}{*}{ YJ2 } & $03-27-90$ & - & -- & 1,090 & 7.36 & - & $<.1$ & -- & - & 1 & 90 \\
\hline & $07-16-90$ & -- & 17 & 621 & 34.9 & -- & $<.1$ & -- & -- & 2 & 90 \\
\hline & $11-14-90$ & .3 & 12 & 869 & 19.5 & $<.01$ & $<.1$ & .05 & $<.01$ & 1 & 70 \\
\hline \multirow[t]{3}{*}{ NW } & $03-28-90$ & -- & -- & 5,850 & 13.7 & -- & 17.0 & -- & -- & $<1$ & 720 \\
\hline & $07-18-90$ & -- & 8.8 & 999 & 51.0 & -- & 1.0 & -- & .. & 1 & 140 \\
\hline & $11-06-90$ & .4 & 7.3 & 1,880 & 45.7 & .01 & 2.1 & .01 & $<.01$ & $<1$ & 190 \\
\hline
\end{tabular}


Table 22. Physical properties and inorganic constituent concentrations in water samples collected in the Dolores Project area from March through November, 1990--Continued

\begin{tabular}{|c|c|c|c|c|c|c|c|c|c|c|c|}
\hline $\begin{array}{c}\text { Site } \\
\text { number } \\
\text { (figs. 1, } \\
\text { 2) }\end{array}$ & Date & $\begin{array}{l}\text { Cad- } \\
\text { mium, } \\
\text { dls- } \\
\text { solved } \\
\text { ( } \mu \text { gh } \\
\text { as Cd) }\end{array}$ & $\begin{array}{l}\text { Chro- } \\
\text { mlum, } \\
\text { dls- } \\
\text { solved } \\
(\mu g / \text { } \\
\text { as Cr) }\end{array}$ & $\begin{array}{l}\text { Copper, } \\
\text { dls- } \\
\text { solved } \\
\text { ( } \mu \mathrm{g} / \mathrm{L} \\
\text { as Cu) }\end{array}$ & $\begin{array}{l}\text { Lead, } \\
\text { dls- } \\
\text { solved } \\
\text { ( } \mu \mathrm{g} / \mathrm{L} \\
\text { as } \mathrm{Pb})\end{array}$ & $\begin{array}{l}\text { Mer- } \\
\text { cury, } \\
\text { dls- } \\
\text { soived } \\
(\mu g / L \\
\text { as Hg) }\end{array}$ & $\begin{array}{l}\text { Molyb- } \\
\text { denum, } \\
\text { dls- } \\
\text { solved } \\
\text { ( } \mu g / \text { } \\
\text { as Mo) }\end{array}$ & $\begin{array}{l}\text { Sele- } \\
\text { nlum, } \\
\text { dis- } \\
\text { solved } \\
\text { ( } \mu \mathrm{gh} \text {. } \\
\text { as Se) }\end{array}$ & $\begin{array}{l}\text { Vana- } \\
\text { dlum, } \\
\text { dls- } \\
\text { solved } \\
(\mu g / L \\
\text { as V) }\end{array}$ & $\begin{array}{c}\text { Zlnc, } \\
\text { dis- } \\
\text { solved } \\
(\mu g h \\
\text { as } \mathrm{Zn})\end{array}$ & $\begin{array}{c}\text { Ura- } \\
\text { nlum, } \\
\text { natural } \\
\text { totai } \\
(\mu g h \\
\text { as U) }\end{array}$ \\
\hline \multicolumn{12}{|c|}{ MVIC AREA-Continued } \\
\hline \multirow[t]{4}{*}{ TT } & $04-17-90$ & $<1$ & $<1$ & 1 & $<1$ & 0.1 & 1 & $<1$ & $<1$ & $<3$ & 1.8 \\
\hline & $04-17-90$ & $<1$ & $<1$ & 2 & $<1$ & $<.1$ & $<1$ & $<1$ & $<1$ & $<3$ & 1.6 \\
\hline & $11-08-90$ & $<1$ & $<1$ & $<1$ & $<1$ & $<.1$ & $<1$ & $<1$ & 1 & 7 & 2.3 \\
\hline & $11-08-90$ & 1 & $<1$ & 1 & $<1$ & $<.1$ & $<1$ & $<1$ & 1 & 12 & 6.0 \\
\hline \multirow[t]{3}{*}{ SD } & $03-28-90$ & $<1$ & $<1$ & 1 & $<1$ & .1 & 2 & $<1$ & $<1$ & $<10$ & 4.2 \\
\hline & $07-18-90$ & $<1$ & 1 & 1 & $<1$ & $<.1$ & 2 & $<1$ & 5 & $<10$ & 4.7 \\
\hline & $11-08-90$ & 3 & 1 & $<1$ & $<1$ & $<.1$ & $<1$ & $<1$ & 1 & $<10$ & 1.4 \\
\hline \multirow[t]{3}{*}{ HD1 } & $03-28-90$ & $<1$ & $<1$ & 1 & $<1$ & $<.1$ & 1 & $<1$ & $<1$ & 20 & 3.0 \\
\hline & $07-18-90$ & 2 & $<1$ & 1 & $<1$ & $<.1$ & 1 & $<1$ & 3 & 35 & 1.4 \\
\hline & $11-13-90$ & $<1$ & $<1$ & 1 & $<1$ & $<.1$ & $<1$ & $<1$ & $<1$ & 6 & 3.7 \\
\hline \multirow[t]{3}{*}{ HD2 } & $03-28-90$ & $<1$ & 1 & 2 & $<1$ & $<.1$ & 1 & 2 & $<1$ & $<10$ & 5.3 \\
\hline & $07-18-90$ & 2 & 3 & 2 & $<1$ & $<.1$ & 1 & $<1$ & 4 & 8 & 2.0 \\
\hline & $11-13-90$ & $<1$ & 1 & 1 & $<1$ & $<.1$ & $<1$ & $<1$ & $<1$ & $<10$ & -- \\
\hline \multirow[t]{3}{*}{ AK } & $03-28-90$ & $<1$ & $<1$ & 2 & $<1$ & $<.1$ & 1 & $<1$ & $<1$ & $<10$ & 5.6 \\
\hline & $07-18-90$ & 1 & $<1$ & 2 & $<1$ & $<.1$ & 1 & $<1$ & 5 & 15 & 2.3 \\
\hline & $11-09-90$ & 1 & $<1$ & 1 & $<1$ & $<.1$ & $<1$ & $<1$ & 1 & $<10$ & 4.4 \\
\hline \multirow[t]{3}{*}{ DD } & $04-11-90$ & $<1$ & $<1$ & 1 & $<1$ & $<.1$ & 1 & $<1$ & 3 & $<10$ & 4.0 \\
\hline & $07-19-90$ & $<1$ & $<1$ & 1 & $<1$ & $<.1$ & 1 & $<1$ & 8 & 9 & $<1.0$ \\
\hline & $11-09-90$ & $<1$ & $<1$ & 1 & $<1$ & $<.1$ & $<1$ & $<1$ & 2 & 7 & 5.0 \\
\hline \multirow[t]{3}{*}{ YJ2 } & $03-27-90$ & $<1$ & $<1$ & $<1$ & $<1$ & $<.1$ & $<10$ & $<1$ & $<6$ & 22 & 2.4 \\
\hline & $07-16-90$ & 1 & $<1$ & 3 & 1 & $<.1$ & 1 & $<1$ & 11 & 5 & 2.1 \\
\hline & $11-14-90$ & $<1$ & $<1$ & 1 & $<1$ & $<.1$ & $<1$ & $<1$ & 1 & 5 & 1.9 \\
\hline \multirow[t]{3}{*}{ NW } & $03-28-90$ & $<1$ & $<1$ & 3 & $<1$ & $<.1$ & 5 & 88 & 1 & 10 & 45 \\
\hline & $07-18-90$ & $<1$ & $<1$ & 1 & $<1$ & $<.1$ & 1 & 7 & 6 & 6 & 5.6 \\
\hline & $11-06-90$ & 2 & $<1$ & 1 & $<1$ & $<1$ & $<1$ & 12 & 2 & $<10$ & 5.7 \\
\hline
\end{tabular}


Table 22. Physical properties and inorganic constituent concentrations in water samples collected in the Dolores Project area from March through November, 1990--Continued

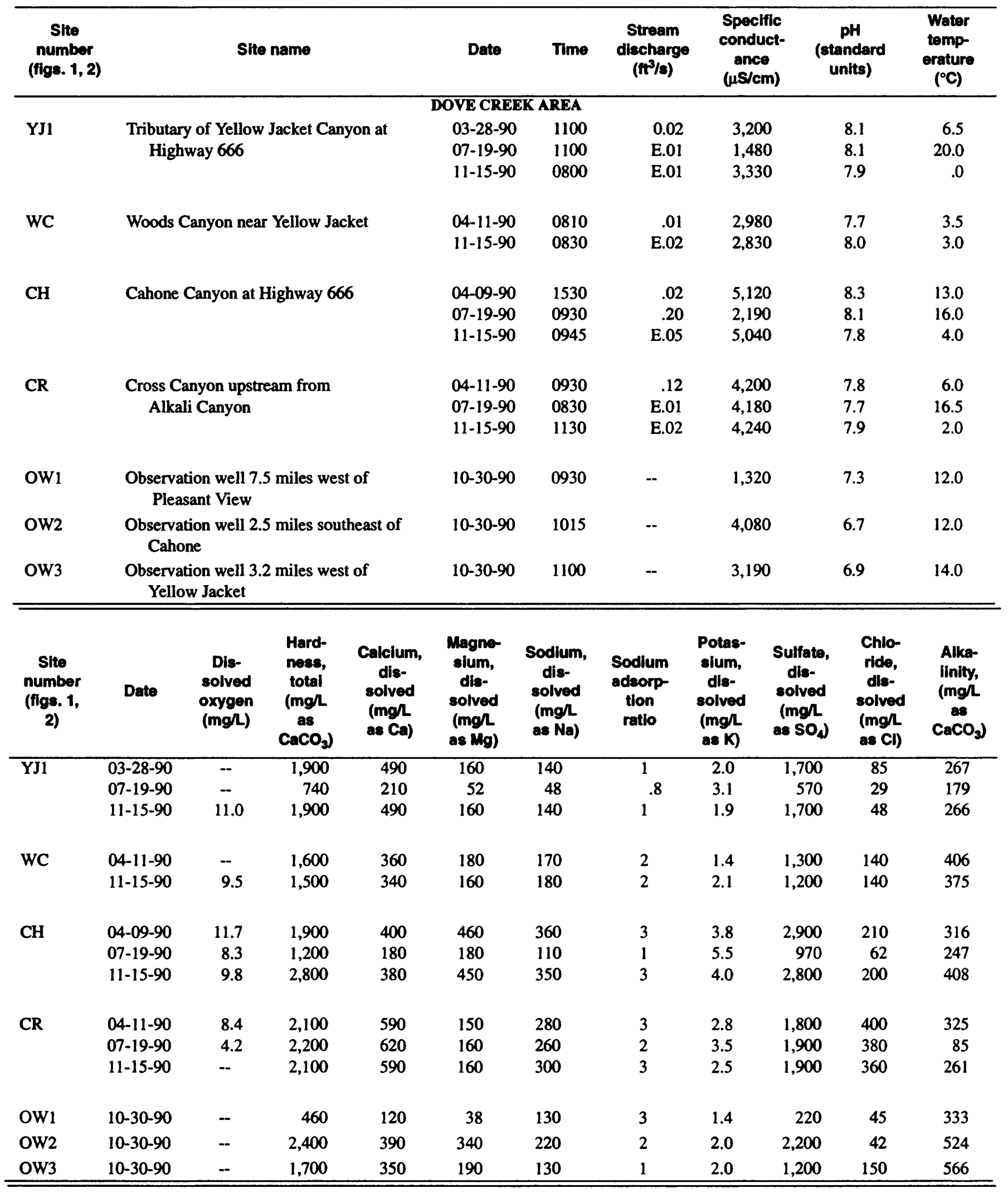


Table 22. Physical properties and inorganic constituent concentrations in water samples collected in the Dolores Project area from March through November, 1990--Continued

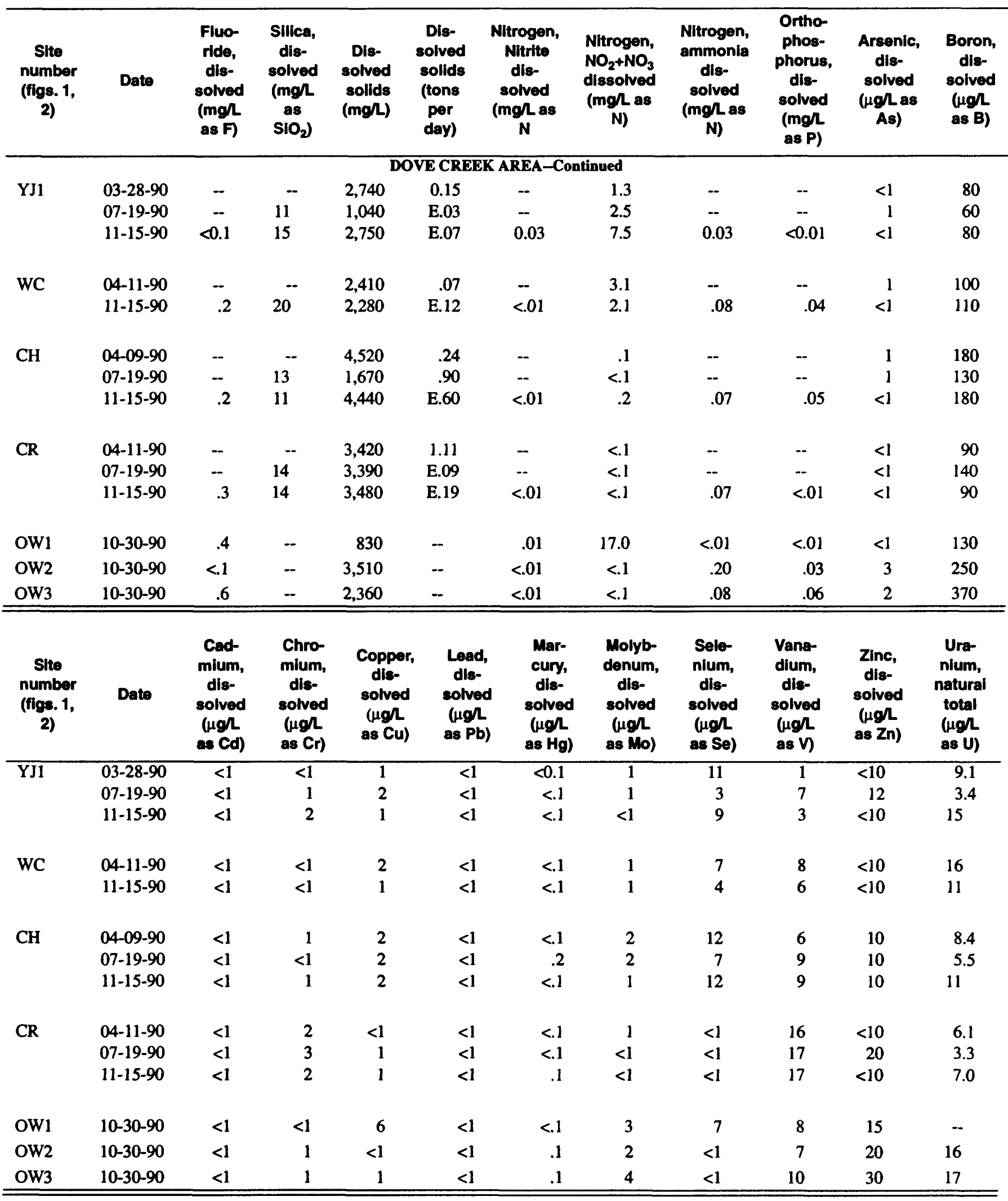


Table 22. Physical properties and inorganic constituent concentrations in water samples collected in the Dolores Project area from March through November, 1990--Continued

\begin{tabular}{|c|c|c|c|c|c|c|c|c|c|c|c|}
\hline $\begin{array}{c}\text { Site } \\
\text { number } \\
\text { (figs. 1, 2) }\end{array}$ & \multicolumn{4}{|c|}{ Site name } & Date & Time & $\begin{array}{c}\text { Stream } \\
\text { discharge } \\
\left(\mathrm{ft}^{3} / \mathrm{s}\right)\end{array}$ & \multicolumn{2}{|c|}{$\begin{array}{c}\text { Specific } \\
\text { conduct- } \\
\text { ance } \\
(\mu S / c m)\end{array}$} & $\begin{array}{l}\text { pH } \\
\text { (standard } \\
\text { units) }\end{array}$ & \multirow[t]{2}{*}{$\begin{array}{l}\text { Water } \\
\text { tomp- } \\
\text { erature } \\
\left({ }^{\circ} \mathrm{C}\right)\end{array}$} \\
\hline & & & & \multicolumn{4}{|c|}{ MANCOS AND SAN JUAN RIVERS } & & & & \\
\hline \multirow[t]{3}{*}{ MN1 } & \multirow{3}{*}{\multicolumn{3}{|c|}{ Mancos River at Highway 666}} & \multirow{2}{*}{\multicolumn{2}{|c|}{$\begin{array}{l}04-10-90 \\
07-17-90\end{array}$}} & $90 \quad 090$ & 2.9 & \multirow{2}{*}{\multicolumn{2}{|c|}{$\begin{array}{l}2,380 \\
1,540\end{array}$}} & \multirow{2}{*}{$\begin{array}{l}8.3 \\
8.3\end{array}$} & \multirow{3}{*}{$\begin{array}{r}8.0 \\
20.0 \\
7.5\end{array}$} \\
\hline & & & & & & $90 \quad 080$ & 16 & & & & \\
\hline & & & & & $11-06$ & $90 \quad 150$ & 17 & 1,8 & & 8.1 & \\
\hline \multirow[t]{3}{*}{ MN2 } & \multirow{3}{*}{\multicolumn{4}{|c|}{$\begin{array}{l}\text { Mancos River at Colorado-New Mexico } \\
\text { State line }\end{array}$}} & \multirow{3}{*}{\multicolumn{2}{|c|}{$\begin{array}{l}04-10-90 \\
07-17-90 \\
11-06-90\end{array}$}} & .89 & \multirow{3}{*}{\multicolumn{2}{|c|}{$\begin{array}{l}2,820 \\
1,820 \\
1,850\end{array}$}} & 8.2 & 11.0 \\
\hline & & & & & & & 49 & & & 8.2 & 21.5 \\
\hline & & & & & & & 31 & & & 8.0 & 7.0 \\
\hline \multirow[t]{3}{*}{ SJ1 } & \multirow{3}{*}{\multicolumn{4}{|c|}{ San Juan River at Four Corners }} & \multirow{3}{*}{\multicolumn{2}{|c|}{$\begin{array}{l}04-10-90 \\
07-17-90 \\
11-07-90\end{array}$}} & 599 & \multicolumn{2}{|c|}{785} & 8.4 & 12.5 \\
\hline & & & & & & & 888 & \multicolumn{2}{|c|}{881} & 8.2 & 26.5 \\
\hline & & & & & & & 1,060 & \multicolumn{2}{|c|}{678} & 8.0 & 6.0 \\
\hline \multirow[t]{3}{*}{ SJ3 } & San Juan & River at $\mathbf{M}$ & exican Hat, & Utah & 04-10 & 151 & 590 & 8 & & 8.5 & 18.0 \\
\hline & & & & & $07-17$ & 123 & 1,680 & 1,1 & & 8.2 & 25.5 \\
\hline & & & & & $11-07$ & 103 & 1,150 & 8 & & 8.3 & 5.5 \\
\hline GW & Seep are & along San & Juan River & at Aneth, & 04-10- & 140 & -- & 13,6 & & 7.5 & 18.5 \\
\hline & Utah & & & & $07-17$ & 141 & .- & 13,9 & & 7.4 & 19.5 \\
\hline & & & & & 11-07. & 130 & -- & 13,5 & & 7.4 & 18.0 \\
\hline $\begin{array}{c}\text { Site } \\
\text { number } \\
\text { (figs. 1, } \\
\text { 2) }\end{array}$ & Date & $\begin{array}{l}\text { Dis- } \\
\text { solved } \\
\text { oxygen } \\
\text { (mg/L) }\end{array}$ & $\begin{array}{c}\text { Hard- } \\
\text { ness, } \\
\text { total } \\
(\mathrm{mg} / \mathrm{l} \\
\mathrm{as} \\
\left.\mathrm{CaCO}_{3}\right)\end{array}$ & $\begin{array}{l}\text { Caicium, } \\
\text { dis- } \\
\text { solved } \\
\text { (mgh } \\
\text { as Ca) }\end{array}$ & $\begin{array}{l}\text { Magne- } \\
\text { sium, } \\
\text { dis- } \\
\text { solved } \\
\text { (mgh } \\
\text { as Mg) }\end{array}$ & $\begin{array}{l}\text { Sodium } \\
\text { dis- } \\
\text { solved } \\
\text { (mg/h } \\
\text { as } \mathrm{Na} \text { ) }\end{array}$ & $\begin{array}{l}\text { Sodium } \\
\text { adsorp- } \\
\text { tion } \\
\text { ratio }\end{array}$ & $\begin{array}{l}\text { Potas- } \\
\text { slum, } \\
\text { dis- } \\
\text { solvod } \\
\text { (mg/L } \\
\text { as K) }\end{array}$ & $\begin{array}{l}\text { Sulfate, } \\
\text { dis- } \\
\text { solved } \\
\text { (mg/L } \\
\left.\text { as SO } \mathrm{SO}_{4}\right)\end{array}$ & $\begin{array}{l}\text { Chio- } \\
\text { ride, } \\
\text { dis- } \\
\text { soived } \\
\text { (mg/L } \\
\text { as Cl) }\end{array}$ & $\begin{array}{c}\text { Alka- } \\
\text { linity, } \\
\text { (mg/l } \\
\text { as } \\
\left.\mathrm{CaCO}_{3}\right)\end{array}$ \\
\hline MN1 & $04-10-90$ & 8.9 & 1,100 & 220 & 140 & 170 & 2 & 4.2 & 1,200 & 21 & 189 \\
\hline & $07-17-90$ & 7.2 & 660 & 160 & 64 & 87 & 1 & 6.1 & 740 & 9.2 & 141 \\
\hline & $11-06-90$ & 10.0 & 860 & 180 & 100 & 120 & 2 & 3.9 & 870 & 19 & 190 \\
\hline MN2 & $04-10-90$ & 8.5 & 1,300 & 240 & 160 & 220 & 3 & 4.9 & 1,400 & 38 & 200 \\
\hline & $07-17-90$ & 7.1 & 820 & 200 & 79 & 120 & 2 & 8.0 & 870 & 23 & 156 \\
\hline & $11-06-90$ & 10.2 & 850 & 180 & 98 & 120 & 2 & 4.2 & 820 & 21 & 190 \\
\hline SJ1 & $04-10-90$ & 8.4 & 240 & 70 & 15 & 68 & 2 & 2.4 & 210 & 19 & 128 \\
\hline & $07-17-90$ & 6.1 & 230 & 75 & 10 & 81 & 2 & 4.6 & 280 & 16 & 144 \\
\hline & $11-07-90$ & 10.0 & 240 & 75 & 14 & 49 & 1 & 2.4 & 170 & 13 & 135 \\
\hline SJ3 & $04-10-90$ & 9.0 & 280 & 78 & 21 & 68 & 2 & 2.6 & 260 & 22 & 135 \\
\hline & $07-17-90$ & 6.7 & 370 & 110 & 22 & 86 & 2 & 5.0 & 380 & 39 & 153 \\
\hline & $11-07-90$ & 10.2 & 280 & 80 & 19 & 66 & 2 & 2.8 & 250 & 17 & 137 \\
\hline GW & $04-10-90$ & -- & 390 & 89 & 41 & 2,900 & 64 & 26 & 1,500 & 3,500 & 544 \\
\hline & $07-17-90$ & -- & 410 & 94 & 42 & 2,700 & 58 & 26 & 1,400 & 3,600 & 558 \\
\hline & $11-07-90$ & - & 460 & 110 & 44 & 2,900 & 59 & 26 & 1,400 & 3,900 & 560 \\
\hline
\end{tabular}


Table 22. Physical properties and inorganic constituent concentrations in water samples collected in the Dolores Project area from March through November, 1990--Continued

\begin{tabular}{|c|c|c|c|c|c|c|c|c|c|c|c|}
\hline $\begin{array}{c}\text { Site } \\
\text { number } \\
\text { (figs. 1, } \\
\text { 2) }\end{array}$ & Date & $\begin{array}{l}\text { Fluo- } \\
\text { ride, } \\
\text { dis- } \\
\text { solvod } \\
\text { (mg/. } \\
\text { as F) }\end{array}$ & $\begin{array}{c}\text { Silica, } \\
\text { dis- } \\
\text { solved } \\
(\mathrm{mgh} \\
\mathrm{as} \\
\left.\mathrm{SiO}_{2}\right)\end{array}$ & $\begin{array}{l}\text { Dis- } \\
\text { solved } \\
\text { solids } \\
\text { (mg/L) }\end{array}$ & $\begin{array}{l}\text { Dis- } \\
\text { solved } \\
\text { solids } \\
\text { (tons } \\
\text { per day) }\end{array}$ & $\begin{array}{l}\text { Nitrogen, } \\
\text { Nitrite } \\
\text { dis- } \\
\text { solved } \\
\text { (mg/L as } \\
\text { N }\end{array}$ & $\begin{array}{l}\text { Nitrogen, } \\
\mathrm{NO}_{2}+\mathrm{NO}_{3} \\
\text { dissolved } \\
\text { (mg/L as } \\
\mathrm{N} \text { ) }\end{array}$ & $\begin{array}{l}\text { Nitrogen, } \\
\text { ammonia } \\
\text { dis- } \\
\text { soived } \\
\text { (mg/l as } \\
\text { N) }\end{array}$ & $\begin{array}{c}\text { Ortho- } \\
\text { phos- } \\
\text { phorus, } \\
\text { dis- } \\
\text { solved } \\
\text { (mgh. } \\
\text { as P) }\end{array}$ & $\begin{array}{c}\text { Arsenic, } \\
\text { dis- } \\
\text { solved } \\
(\mu \mathrm{g} / \mathrm{L} \text { as } \\
\text { As })\end{array}$ & $\begin{array}{c}\text { Boron, } \\
\text { dis- } \\
\text { solved } \\
\text { ( } \mu \text { gh } \\
\text { as B) }\end{array}$ \\
\hline \multicolumn{12}{|c|}{ MANCOS AND SAN JUAN RIVERS-Continued } \\
\hline \multirow[t]{3}{*}{ MN1 } & $04-10-90$ & -- & -- & 1,870 & 14.6 & -- & $<0.1$ & -- & -- & $<1$ & 110 \\
\hline & $07-17-90$ & -- & 9.1 & 1,160 & 50.1 & -- & .3 & -- & -- & 1 & 90 \\
\hline & $11-06-90$ & .1 & 8.3 & 1,420 & 65.2 & $<0.01$ & $<.1$ & $<0.01$ & $<0.01$ & $<1$ & 90 \\
\hline \multirow[t]{3}{*}{ MN2 } & $04-10-90$ & -- &.- & 2,180 & 5.24 & -- & .1 & -- & - & $<1$ & 140 \\
\hline & $07-17-90$ & -- & 8.6 & 1,410 & 187 & .- & .8 & .- & -- & 1 & 150 \\
\hline & $11-06-90$ & .3 & 6.8 & 1,370 & 115 & $<.01$ & .9 & $<.01$ & $<.01$ & $<1$ & 110 \\
\hline \multirow[t]{3}{*}{ SJ1 } & $04-10-90$ & -- & -- & 463 & 748 & -- & .3 & - & -- & 1 & 60 \\
\hline & $07-17-90$ & -- & 10 & 566 & 1,360 & -- & .7 & .. & -- & 1 & 70 \\
\hline & $11-07-90$ & .3 & 8.6 & 415 & 1,190 & $<.01$ & .3 & $<.01$ & .03 & 1 & 60 \\
\hline \multirow[t]{3}{*}{ SJ3 } & $04-10-90$ & -- & -- & 533 & 848 & -- & $<.1$ & -- & -- & $<1$ & 70 \\
\hline & $07-17-90$ & -- & 10 & 749 & 3,400 & -- & 1.1 & -- & -- & 1 & 100 \\
\hline & $11-07-90$ & .3 & 8.7 & 528 & 1,640 & $<.01$ & .5 & .02 & .02 & 1 & 60 \\
\hline \multirow[t]{3}{*}{ GW } & $04-10-90$ & -- & -- & 8,380 & -- & -- & .2 & -- & -- & 12 & 60 \\
\hline & $07-17-90$ & -- & 11 & 8,210 & -- & -- & .3 & -- & -- & 11 & 430 \\
\hline & $11-07-90$ & $<.1$ & 10 & 8,730 & - & .01 & .4 & .26 & $<.01$ & 11 & 450 \\
\hline $\begin{array}{c}\text { Site } \\
\text { number } \\
\text { (figs. 1, } \\
\text { 2) }\end{array}$ & Date & $\begin{array}{l}\text { Cad- } \\
\text { mium, } \\
\text { dis- } \\
\text { solved } \\
\text { ( } \mu \mathrm{g} / \\
\text { as Cd) }\end{array}$ & $\begin{array}{l}\text { Chro- } \\
\text { mium, } \\
\text { dis- } \\
\text { solved } \\
\text { ( } \mu \mathrm{g} / \mathrm{L} \\
\text { as Cr) }\end{array}$ & $\begin{array}{c}\text { Copper, } \\
\text { dis- } \\
\text { solved } \\
(\mu g / L \\
\text { as Cu) }\end{array}$ & $\begin{array}{l}\text { Lead, } \\
\text { dis- } \\
\text { solved } \\
(\mu g / L \\
\text { as Pb) }\end{array}$ & $\begin{array}{l}\text { Mer- } \\
\text { cury, } \\
\text { dis- } \\
\text { solved } \\
(\mu g / L \\
\text { as Hg) }\end{array}$ & $\begin{array}{l}\text { Molyb- } \\
\text { denum, } \\
\text { dis- } \\
\text { solved } \\
(\mu \mathrm{g} / \\
\text { as Mo) }\end{array}$ & $\begin{array}{c}\text { Sele- } \\
\text { nium, } \\
\text { dis- } \\
\text { solved } \\
(\mu g / L \\
\text { as Se) }\end{array}$ & $\begin{array}{l}\text { Vana- } \\
\text { dium, } \\
\text { dis- } \\
\text { solved } \\
(\mu \mathrm{g} / \mathrm{L} \\
\text { as V) }\end{array}$ & $\begin{array}{l}\text { Zinc, } \\
\text { dis- } \\
\text { solved } \\
(\mu g / L \\
\text { as } Z n)\end{array}$ & $\begin{array}{c}\text { Ura- } \\
\text { nium, } \\
\text { natural } \\
\text { totai } \\
(\mu g / L \\
\text { as U) }\end{array}$ \\
\hline \multicolumn{12}{|c|}{ MANCOS AND SAN JUAN RIVERS-Continued } \\
\hline \multirow[t]{3}{*}{ MN1 } & $04-10-90$ & $<1$ & $<1$ & 1 & $<1$ & $<.1$ & 2 & 3 & $<1$ & $<10$ & 6.3 \\
\hline & $07-17-90$ & 2 & 3 & 5 & 1 & $<.1$ & 5 & 3 & 7 & 4 & $<1.0$ \\
\hline & $11-06-90$ & $<1$ & $<1$ & 2 & $<1$ & $<.1$ & 3 & 10 & 1 & 6 & 6.4 \\
\hline \multirow[t]{3}{*}{ MN2 } & $04-10-90$ & $<1$ & 1 & 1 & $<1$ & $<.1$ & 3 & 6 & $<1$ & $<10$ & 6.6 \\
\hline & $07-17-90$ & $<1$ & $<1$ & 5 & $<1$ & $<.1$ & 4 & 10 & 9 & 7 & 7.6 \\
\hline & $11-06-90$ & $<1$ & $<1$ & 2 & $<1$ & $<.1$ & $<1$ & 8 & 1 & 7 & 6.4 \\
\hline \multirow[t]{3}{*}{ SJ1 } & $04-10-90$ & 2 & $<1$ & $<3$ & $<1$ & $<.1$ & $<10$ & 1 & $<6$ & 6 & 3.6 \\
\hline & $07-17-90$ & 1 & $<1$ & 15 & 1 & $<.1$ & 2 & 2 & 6 & 4 & 7.4 \\
\hline & $11-07-90$ & $<1$ & $<1$ & 2 & $<1$ & $<.1$ & $<1$ & $<1$ & 1 & 7 & 3.1 \\
\hline \multirow[t]{3}{*}{ SJ3 } & $04-10-90$ & $<1$ & $<1$ & $<4$ & $<1$ & $<.1$ & $<10$ & 1 & $<6$ & 10 & 3.3 \\
\hline & $07-17-90$ & 3 & $<1$ & 3 & $<1$ & $<.1$ & 2 & 2 & 6 & $<3$ & 8.0 \\
\hline & $11-07-90$ & $<1$ & $<1$ & 11 & $<1$ & $<.1$ & $<1$ & $<1$ & 2 & 4 & 4.9 \\
\hline \multirow[t]{3}{*}{ GW } & $04-10-90$ & $<1$ & $<1$ & 1 & $<1$ & .8 & 4 & $<1$ & 13 & 10 & 13 \\
\hline & $07-17-90$ & $<1$ & 4 & 1 & 3 & 1.2 & 4 & $<1$ & 25 & $<10$ & 9.5 \\
\hline & $11-07-90$ & $<1$ & $<1$ & 1 & $<4$ & $<.1$ & 3 & $<1$ & 48 & $<10$ & 13 \\
\hline
\end{tabular}




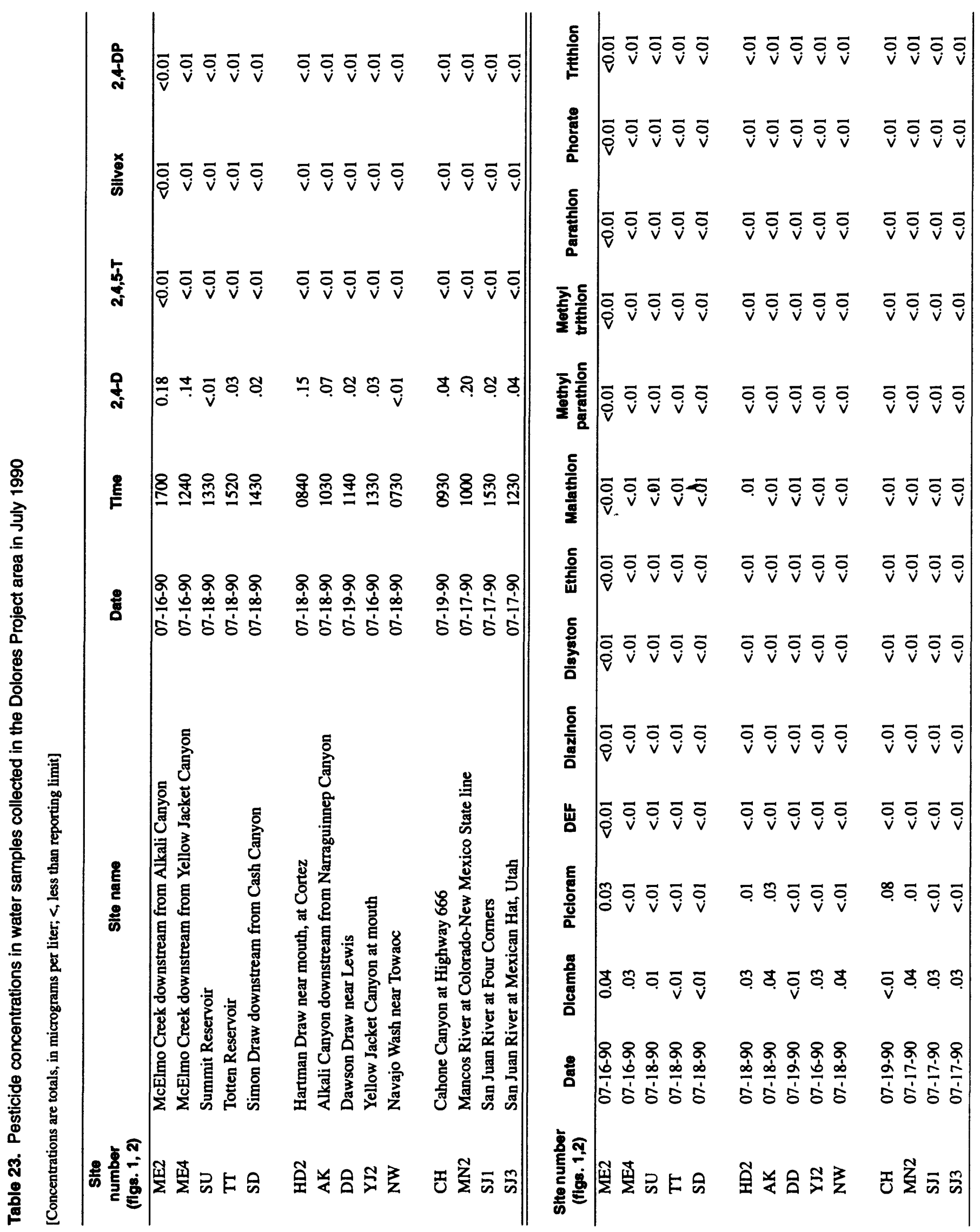

78 Reconnaissance Investigation of Water Quality, Bottom Sediment, and Biota Associated with Irrigation Drainage in the Doiores Project Area, Southwestern Colorado and Southeastern Utah, 1990-91 


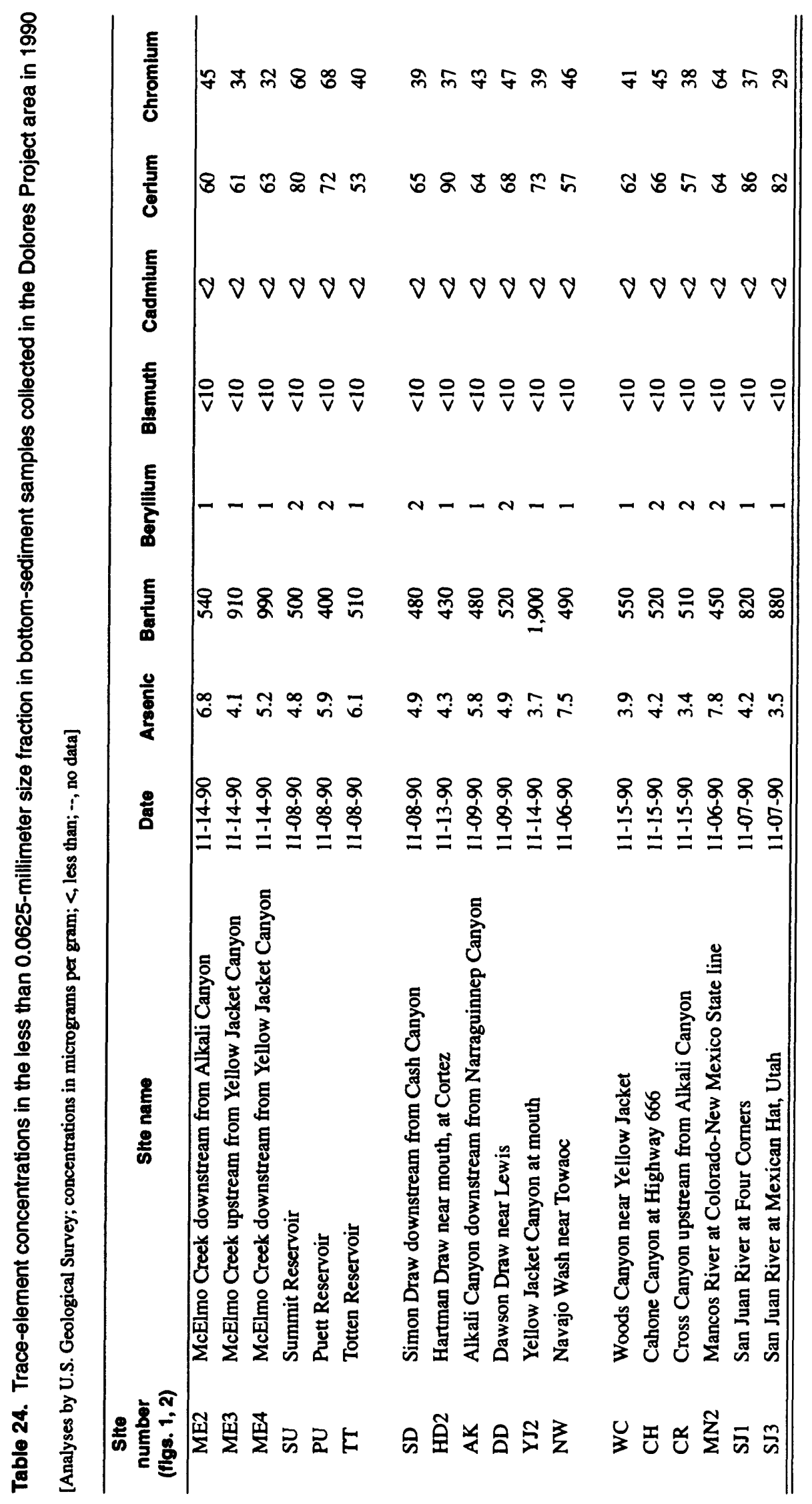




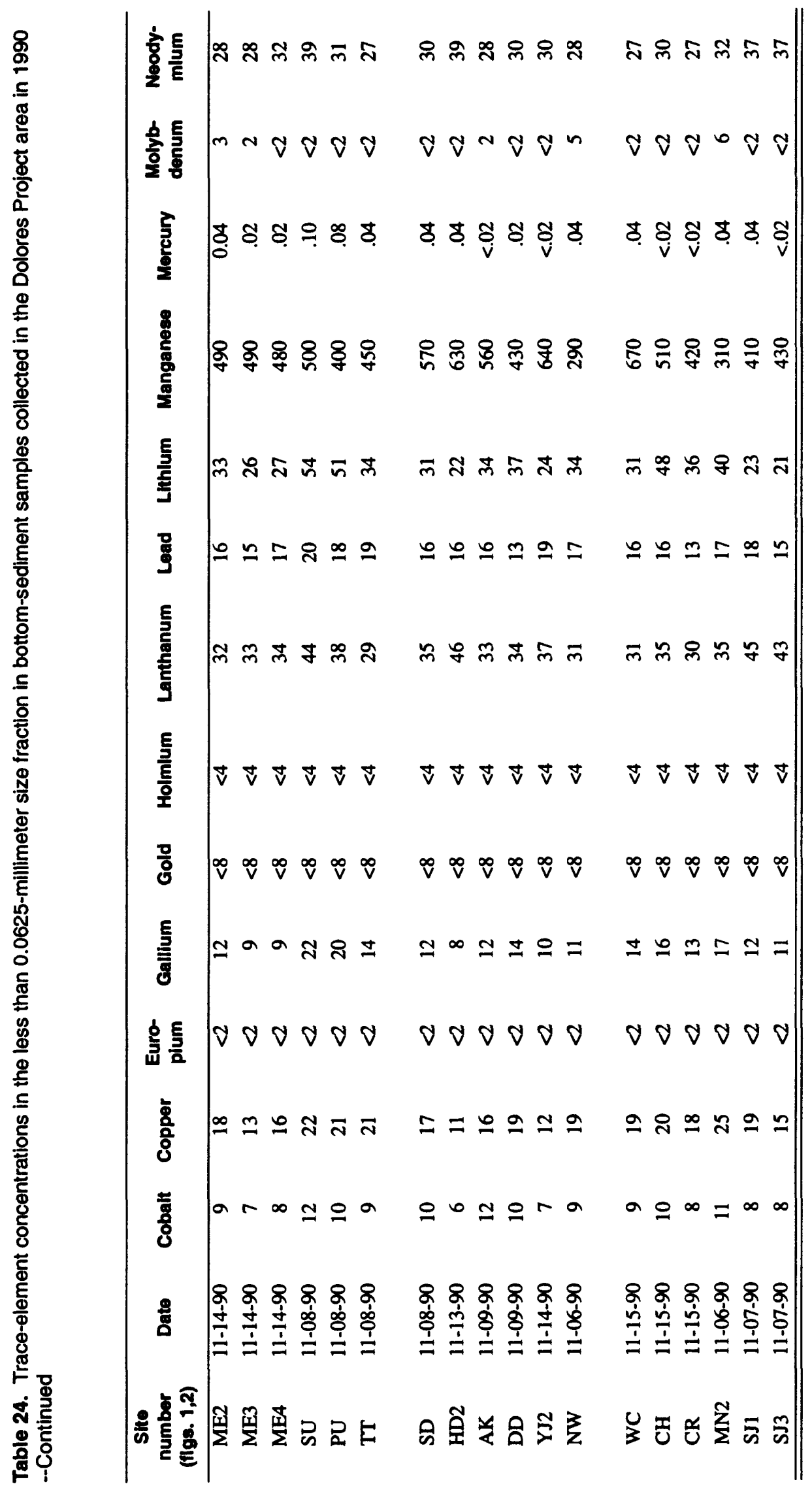

80 Reconnalssance Investigation of Water Quality, Bottom Sediment, and Blota Associated with Irrigation Drainage in the Dolores Project Area, Southwestern Colorado and Southeastern Utah, 1990-91 


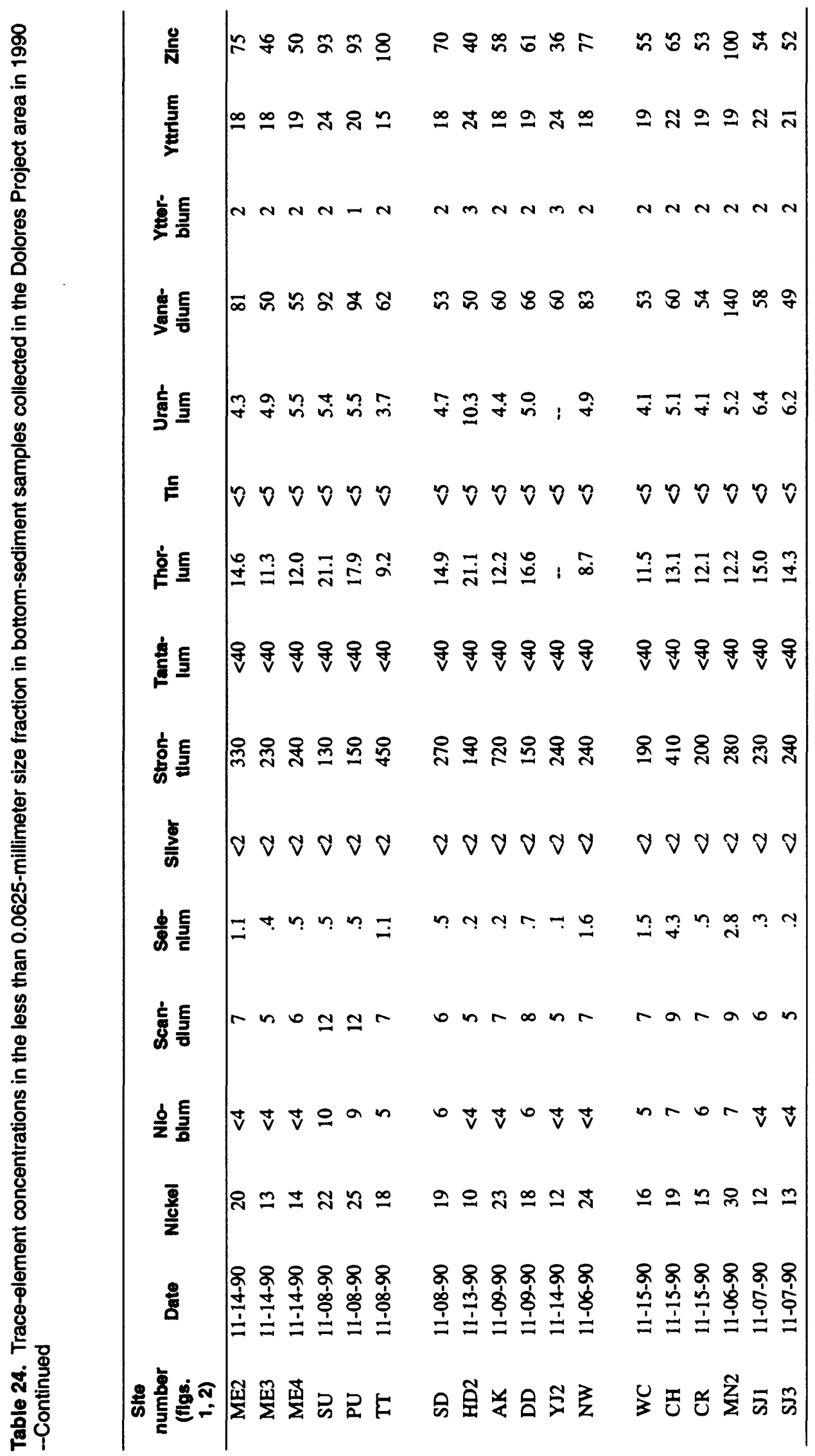




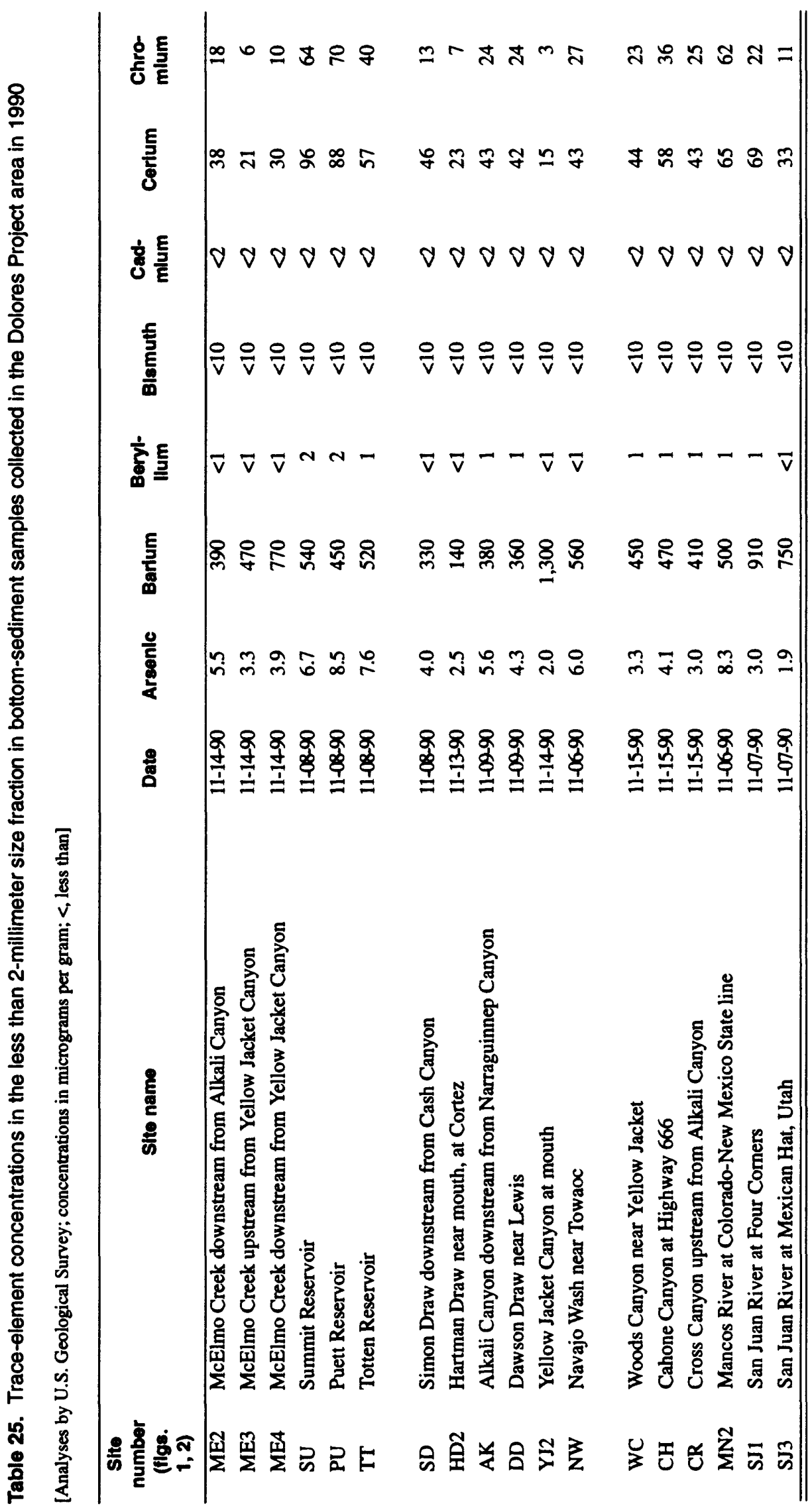

82 Reconnaissance Investigation of Water Quality, Bottom Sediment, and Biota Associated with Irrigation Drainage in the Doiores Project Area, Southwestem Colorado and Southeastern Utah, 1990-91 


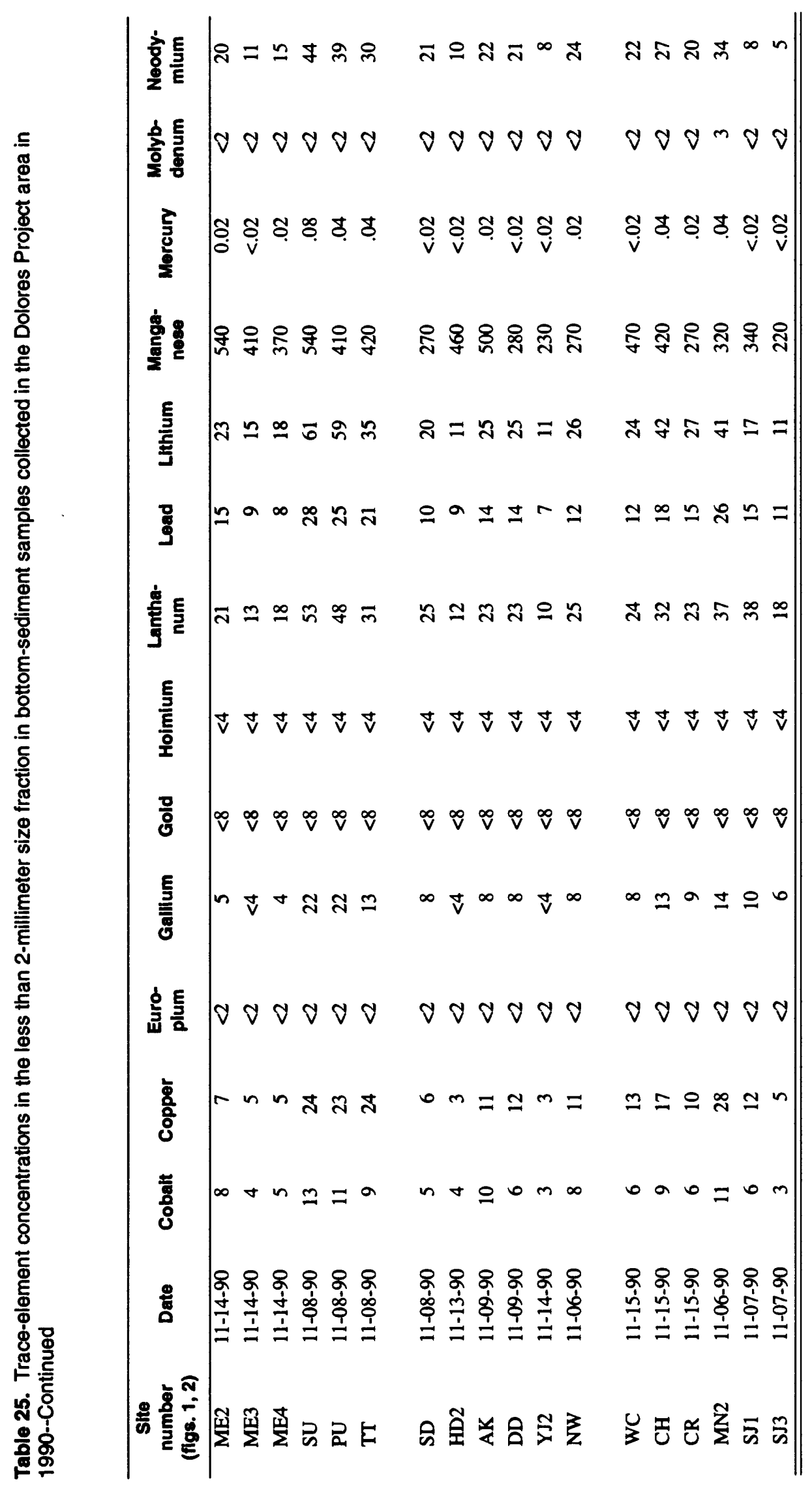




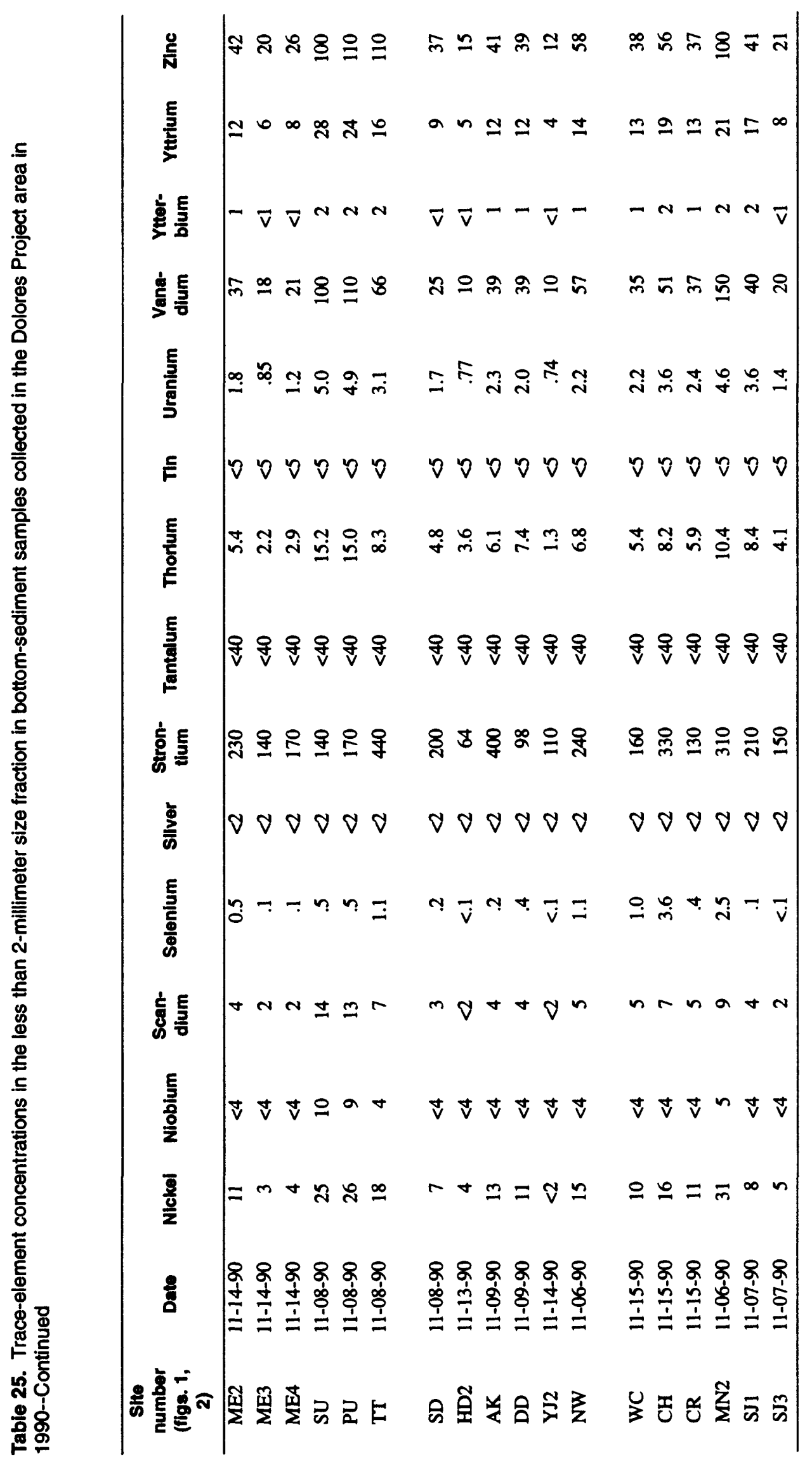




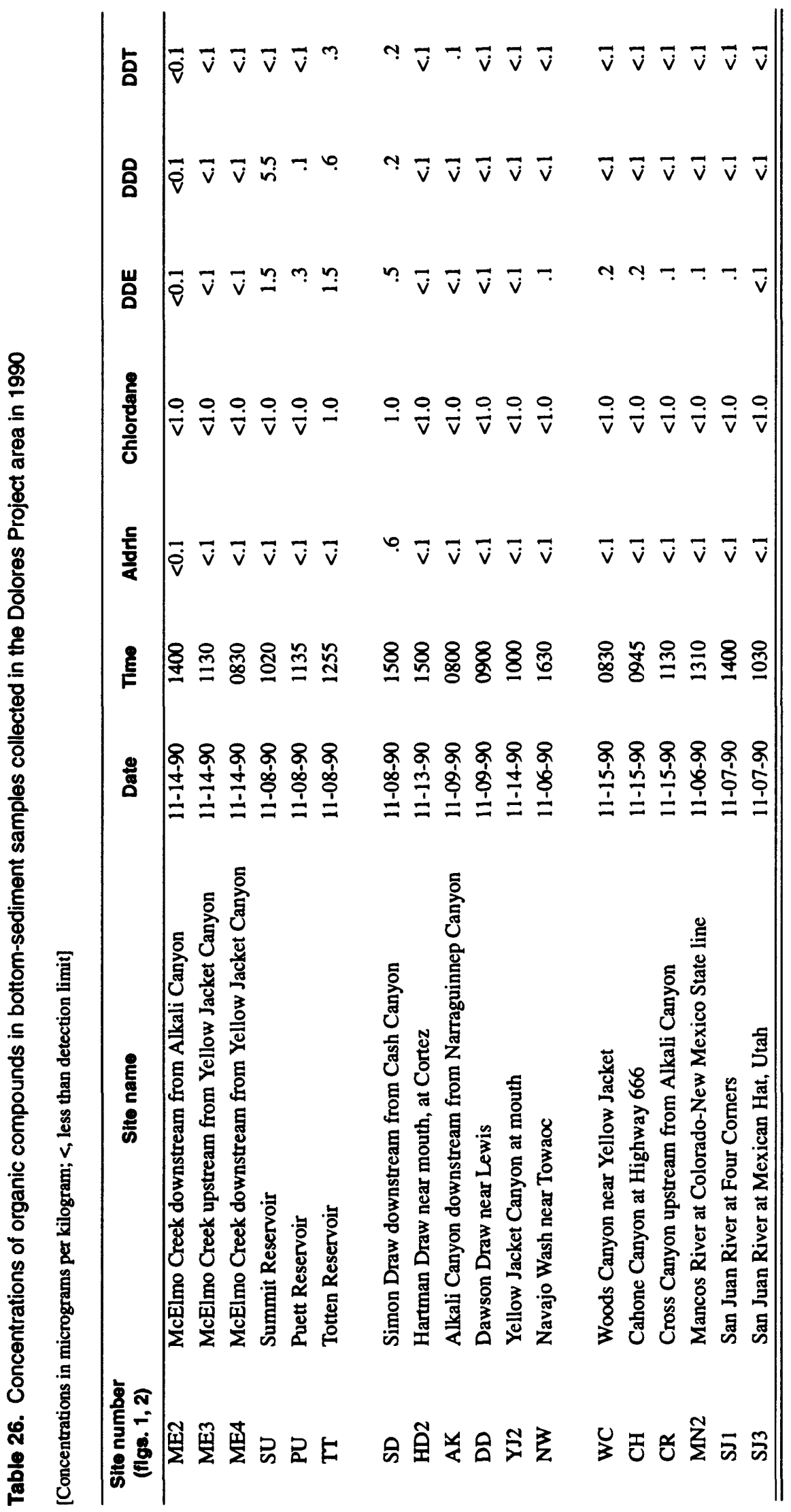




\begin{tabular}{|c|c|c|c|}
\hline zo & o & 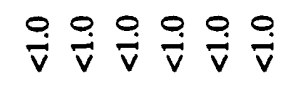 & 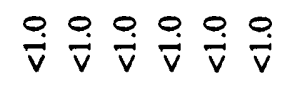 \\
\hline 适 & $\bar{v} \vec{v} \bar{v} \bar{v} \bar{v} \vec{v}$ & $\bar{v} \vec{v} \bar{v} \bar{v} \bar{v} \bar{v}$ & $\bar{v} \bar{v} \bar{v} \bar{v} \bar{v} \bar{v}$ \\
\hline 象 & $\frac{O}{v} \frac{\circ}{v} \frac{O}{v} \stackrel{\circ}{v} \frac{\circ}{v}$ & 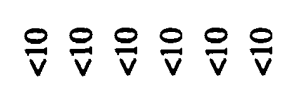 & $\frac{O}{v} \stackrel{\circ}{v} \frac{O}{v} \frac{\circ}{v} \stackrel{\circ}{v}$ \\
\hline 宽 & 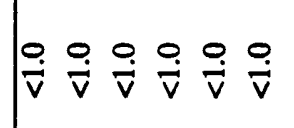 & 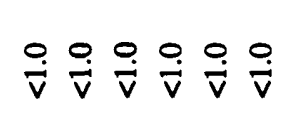 & 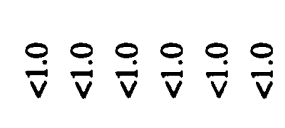 \\
\hline$\frac{\mathbf{x}}{2}$ & $\overrightarrow{\bar{v}} \vec{v} \vec{v} \vec{v} \vec{v} \vec{v}$ & $\vec{v} \vec{v} \vec{v} \vec{v} \vec{v} \vec{v}$ & $\vec{v} \vec{v} \vec{v} \vec{v} \vec{v} \vec{v}$ \\
\hline 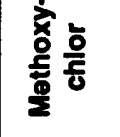 & $\overrightarrow{\vec{v}} \vec{v} \vec{v} \vec{v} \vec{v} \vec{v}$ & $\vec{v} \vec{v} \vec{v} \vec{v} \vec{v} \vec{v}$ & $\vec{v} \vec{v} \vec{v} \vec{v} \vec{v} \vec{v}$ \\
\hline 总 & $\overrightarrow{\bar{v}} \vec{v} \vec{v} \vec{v} \vec{v} \vec{v}$ & $\bar{v} \vec{v} \bar{v} \bar{v} \vec{v} \bar{v}$ & $\vec{v} \vec{v} \vec{v} \vec{v} \bar{v} \vec{v}$ \\
\hline 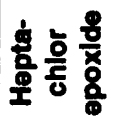 & $\vec{i} \vec{v} \vec{v} \vec{v} \vec{v} \vec{v}$ & $\vec{v} \vec{v} \vec{v} \vec{v} \vec{v} \vec{v}$ & $\vec{v} \vec{v} \vec{v} \vec{v} \vec{v} \vec{v}$ \\
\hline 형흥 & $\overrightarrow{\bar{v}} \vec{v} \vec{v} \vec{v} \vec{v} \vec{v}$ & $\vec{v} \vec{v} \vec{v} \vec{v} \vec{v} \vec{v}$ & $\overrightarrow{\mathrm{v}} \overrightarrow{\mathrm{v}} \overrightarrow{\mathrm{v}} \overrightarrow{\mathrm{v}} \overrightarrow{\mathrm{v}} \overrightarrow{\mathrm{v}}$ \\
\hline $\begin{array}{l}\text { 둫 } \\
\text { 悹 }\end{array}$ & $\overrightarrow{\bar{v}} \vec{v} \vec{v} \vec{v} \vec{v} \vec{v}$ & $\vec{v} \vec{v} \vec{v} \vec{v} \vec{v} \vec{v}$ & $\vec{v} \vec{v} \vec{v} \vec{v} \vec{v} \vec{v}$ \\
\hline 害 & $\overrightarrow{\bar{v}} \bar{v} \vec{v} \vec{v} \vec{v} \bar{v}$ & $\vec{v} \vec{v} \bar{v} \bar{v} \bar{v} \vec{v}$ & $\vec{v} \vec{v} \vec{v} \vec{v} \vec{v} \vec{v}$ \\
\hline & $\overrightarrow{\bar{v}} \vec{v} \vec{v} \bar{v} \vec{v} \vec{v}$ & $\dddot{q} \vec{v} \vec{v} \vec{v} \vec{v}=$ & $\bar{v} \vec{v} \vec{v} \vec{v} \bar{v} \vec{v}$ \\
\hline$\stackrel{8}{\Delta}$ & 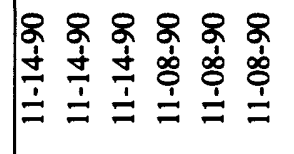 & 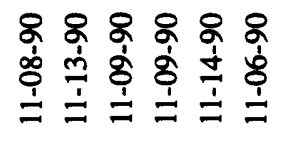 & 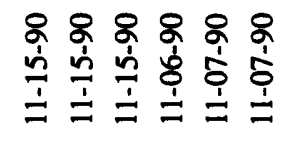 \\
\hline \%ั & 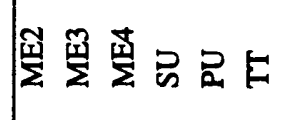 & 的完合会会 & 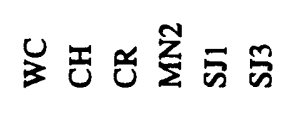 \\
\hline
\end{tabular}




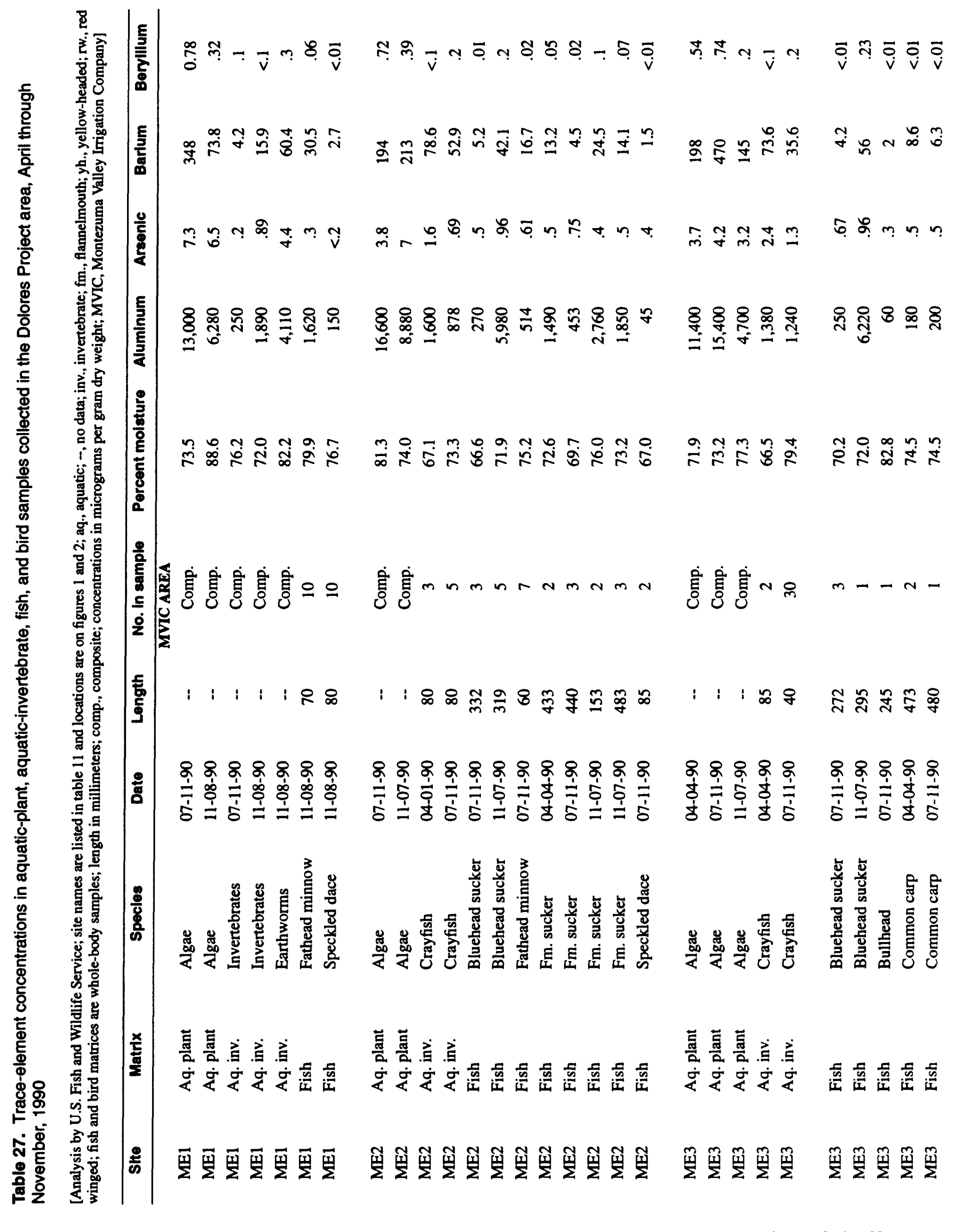




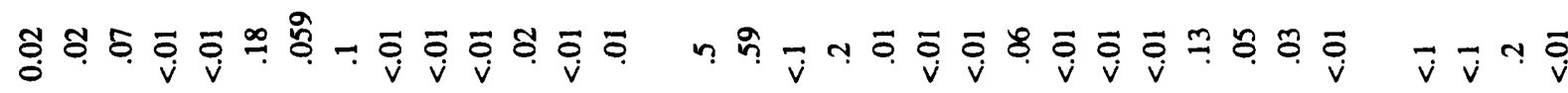

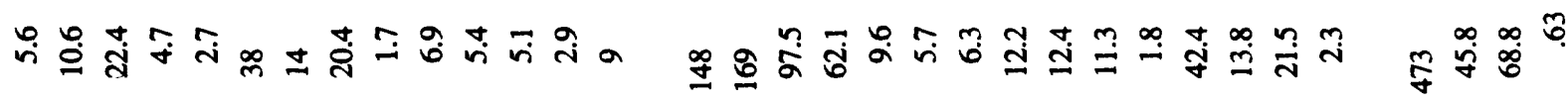

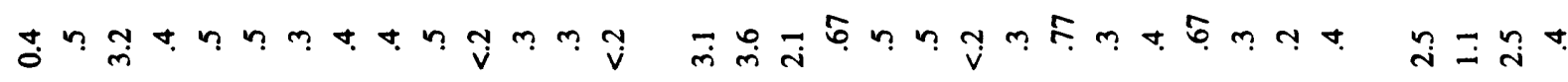

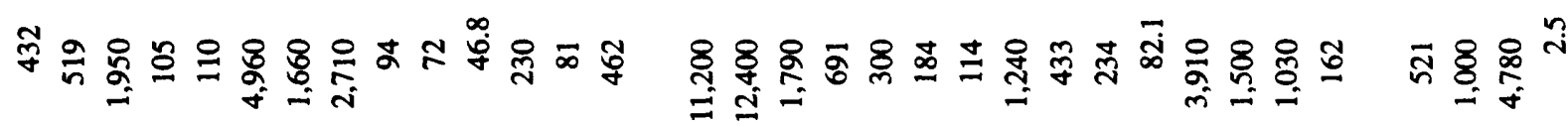

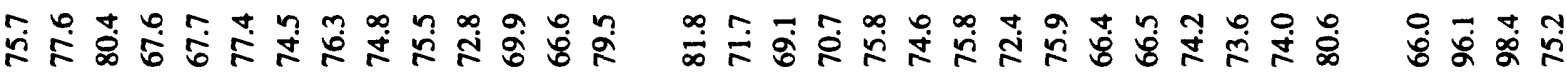

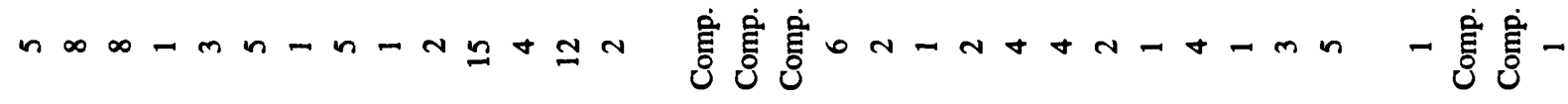

焉喜音

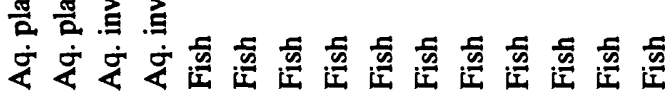

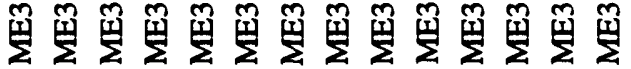




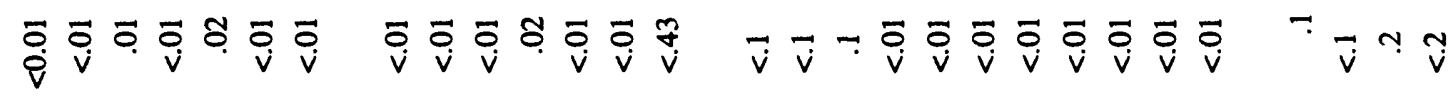

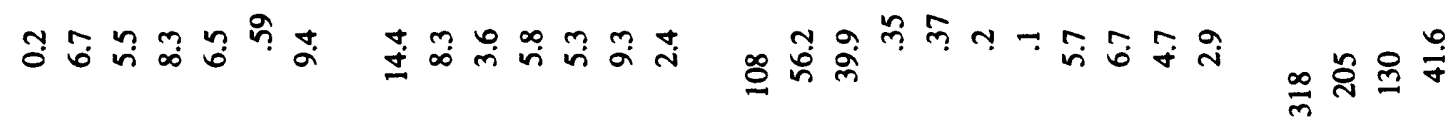

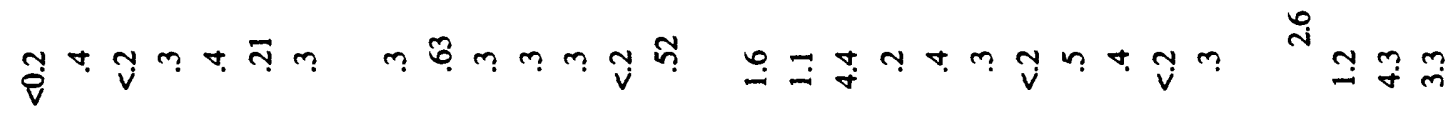

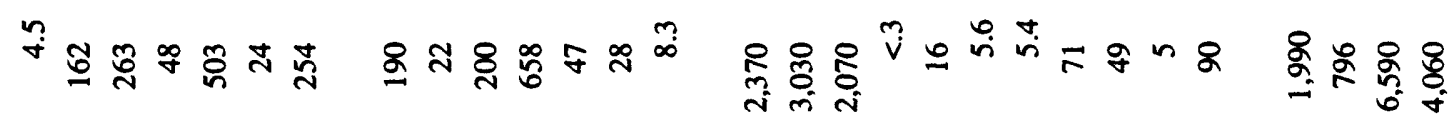

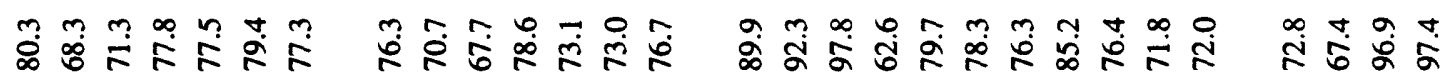

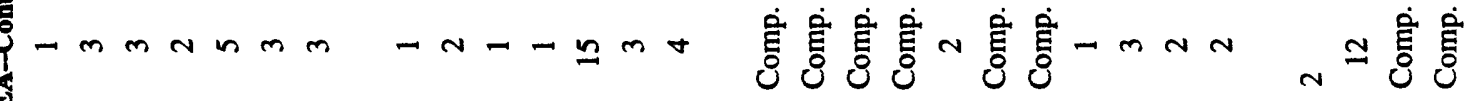

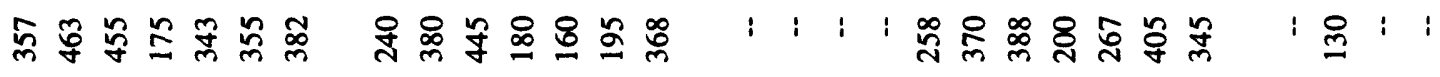

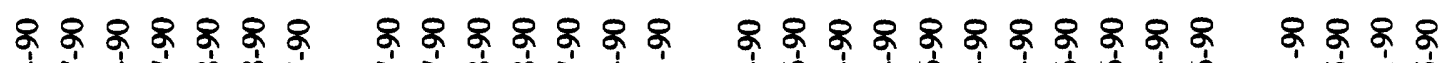

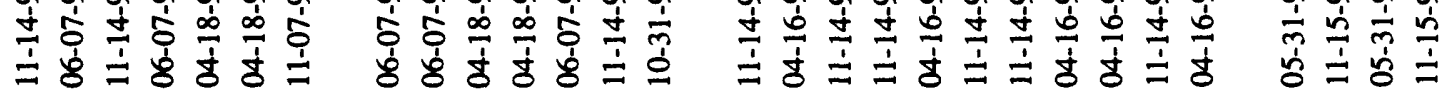

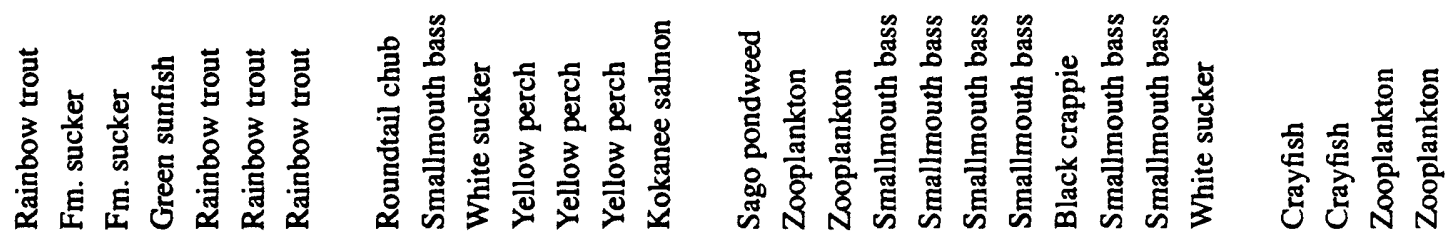

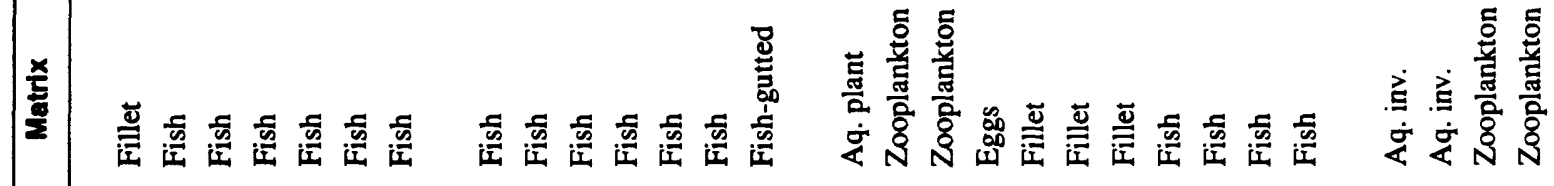

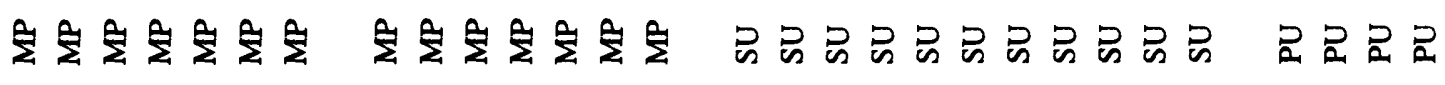




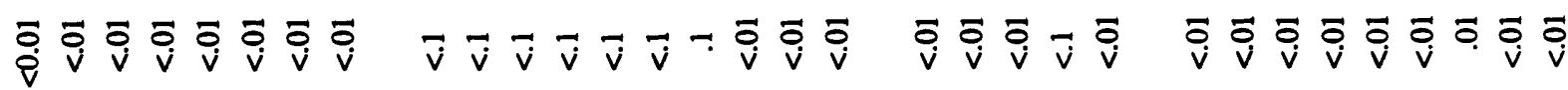

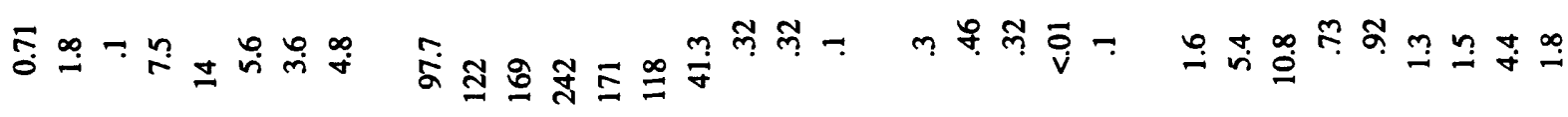

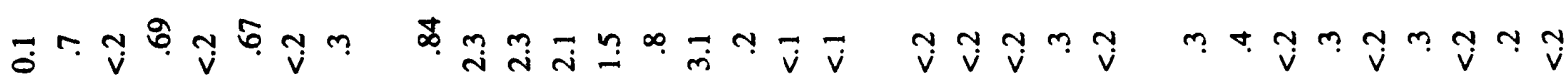

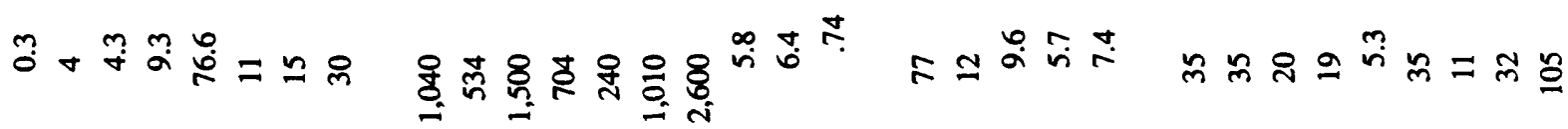

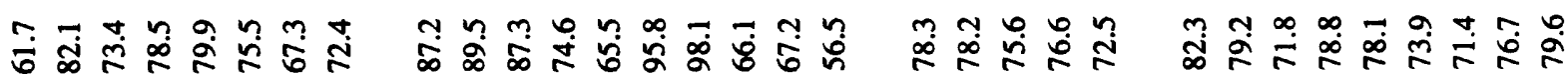

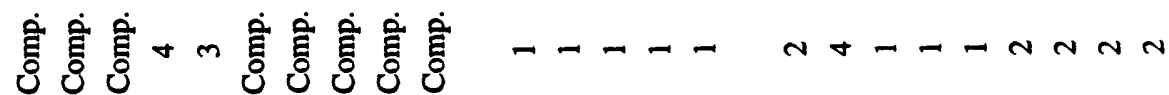

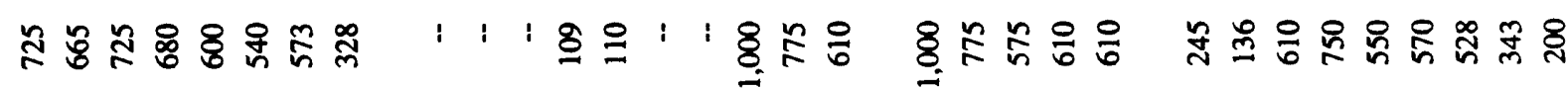

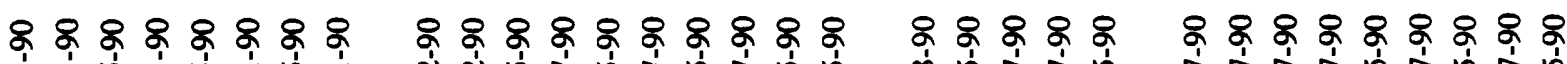

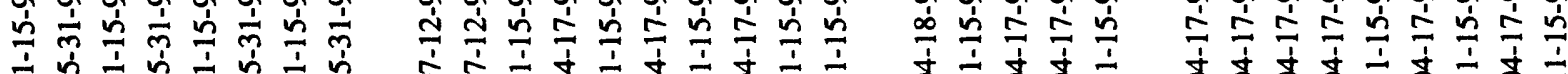

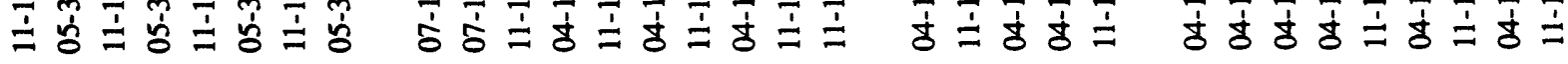

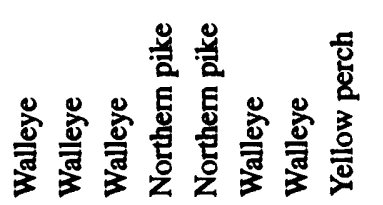

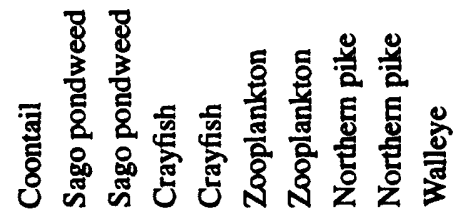

竞育

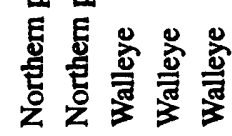

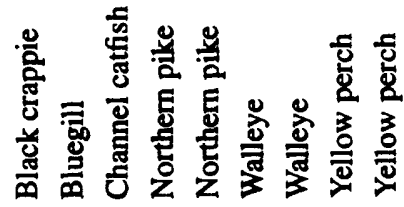

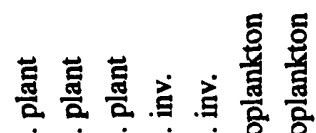

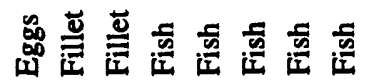

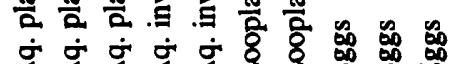

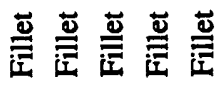

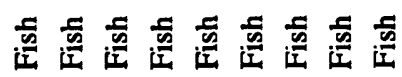




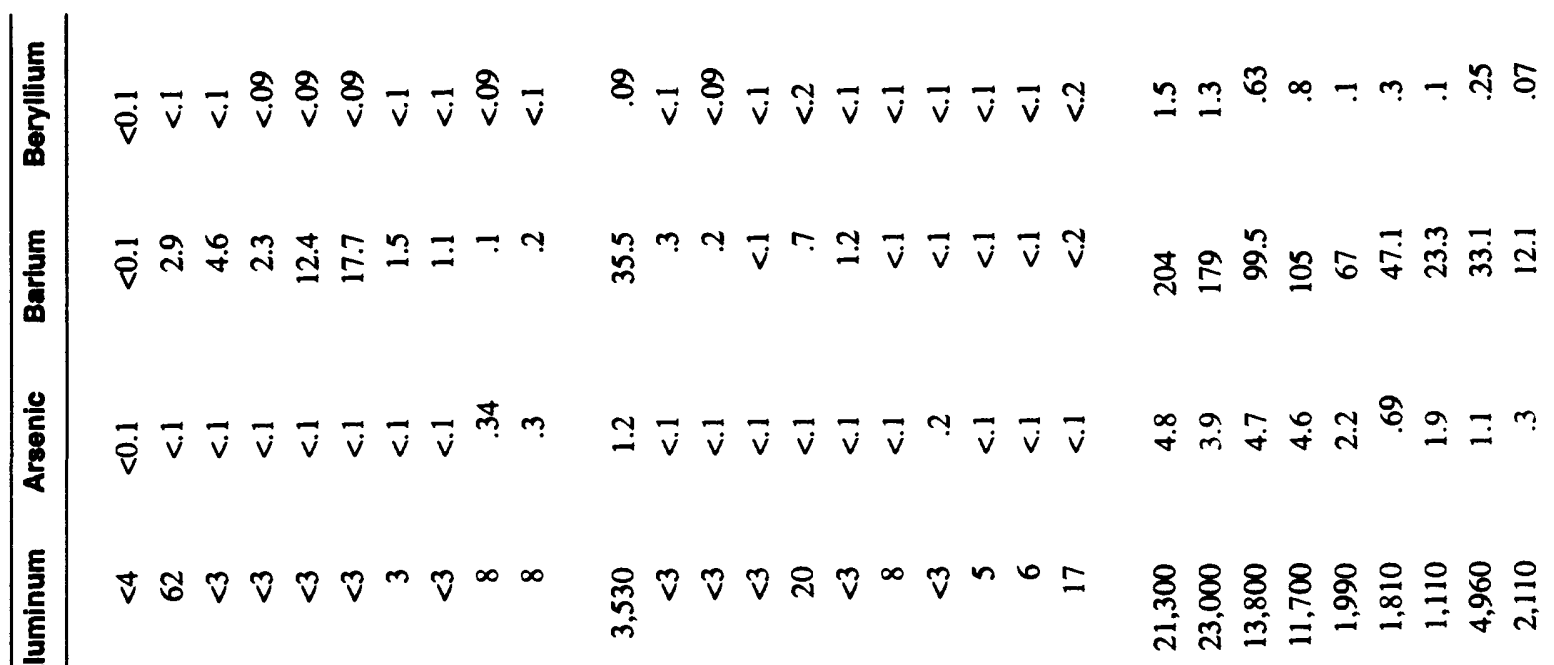

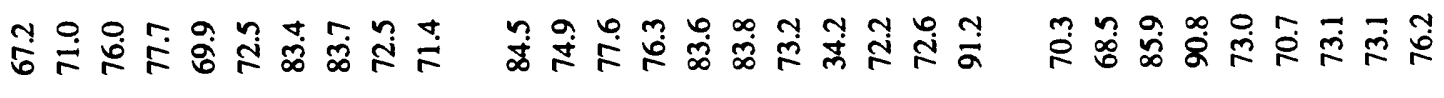

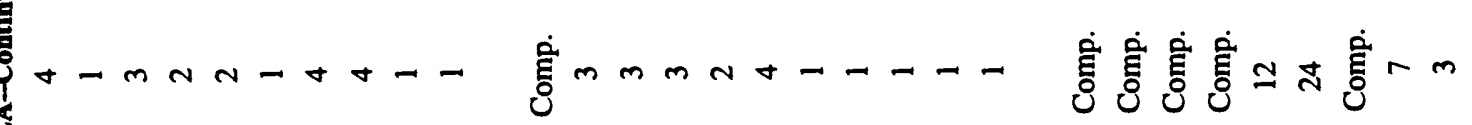

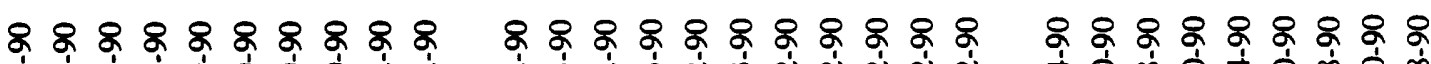

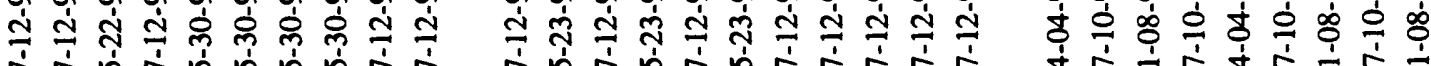

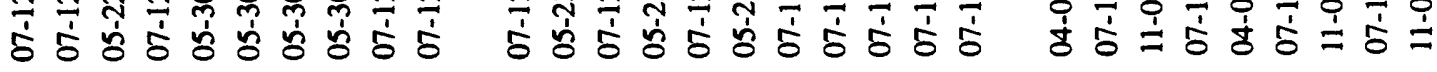

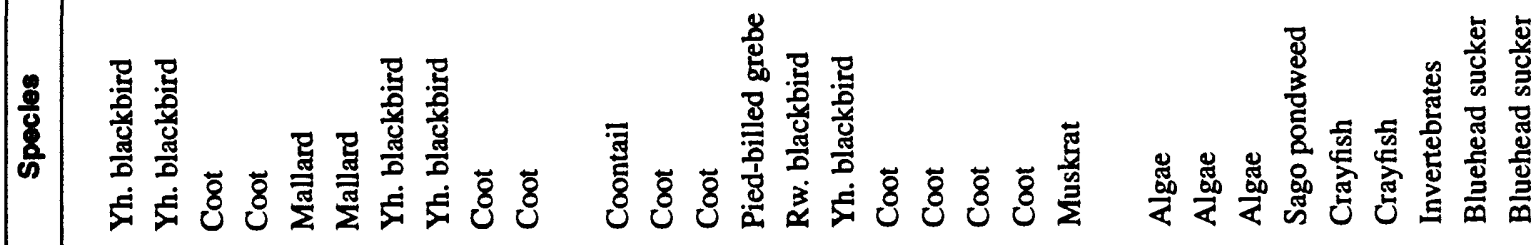

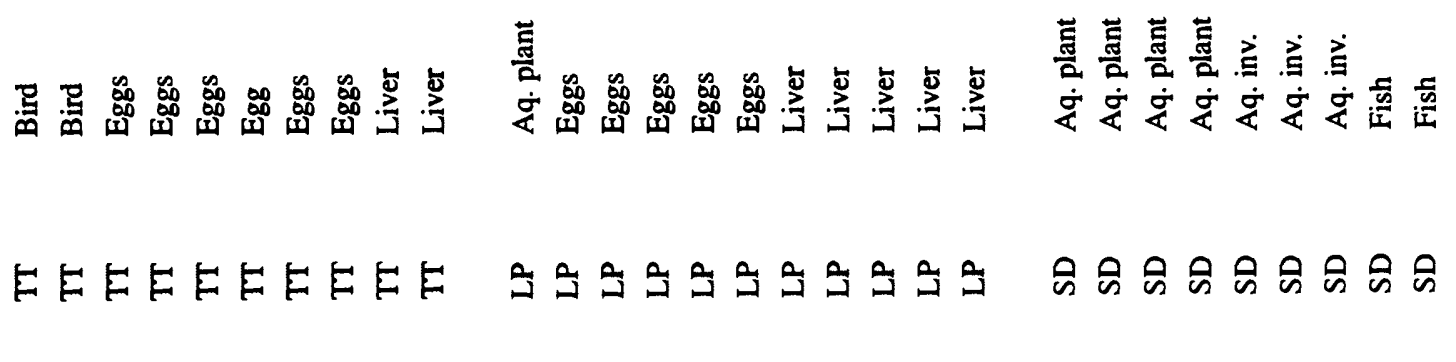




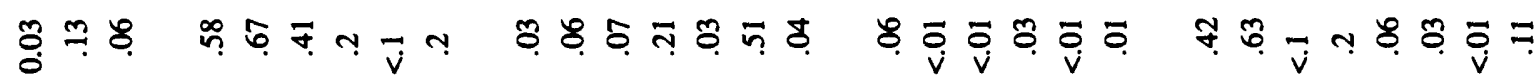

ตั่

乌ூ

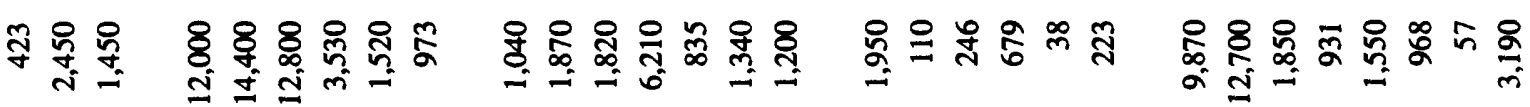

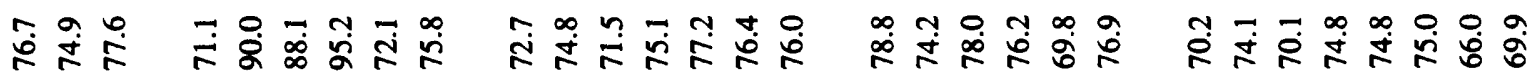

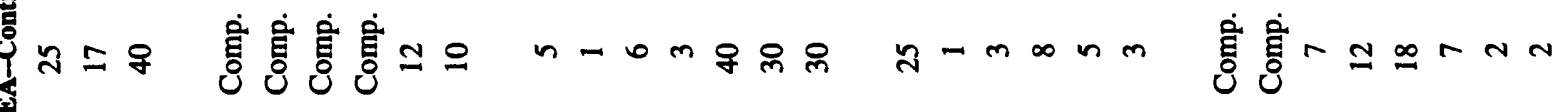

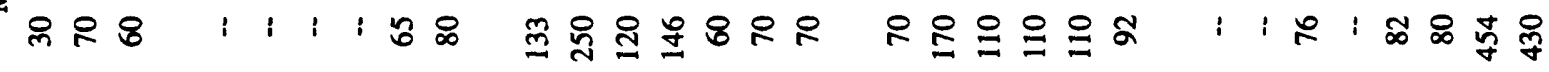

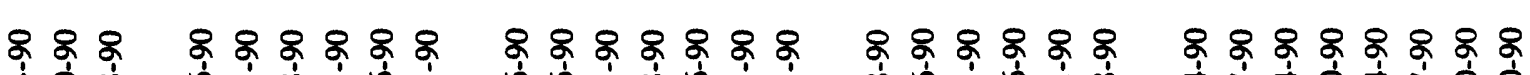

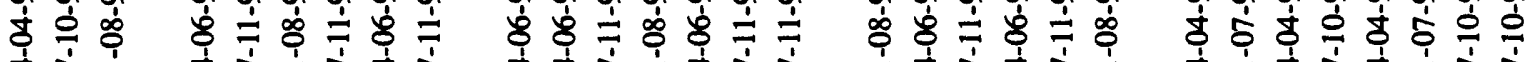

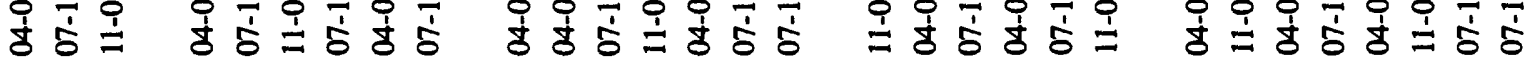

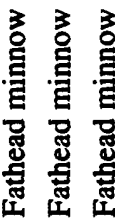

总总总总言言言

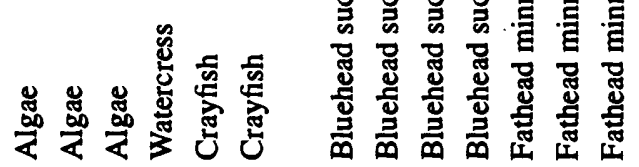

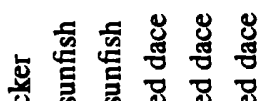

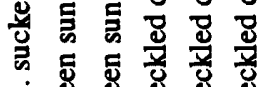

है

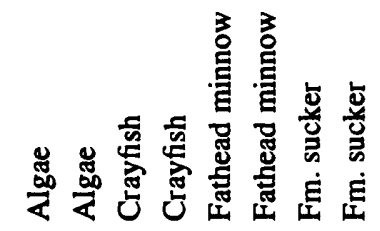

喜喜喜喜家家

受急量

த் த் $\dot{q} \dot{q}$

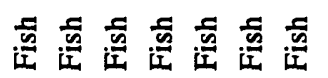

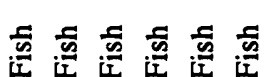

蒙蒙离

Ð

동 


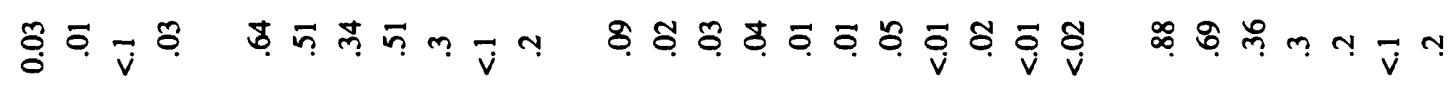

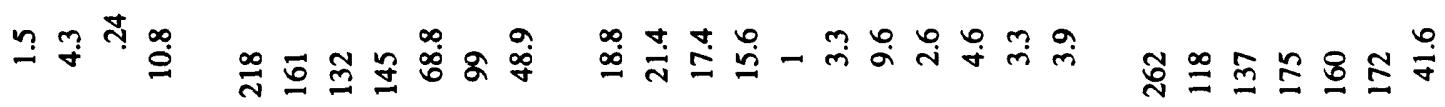

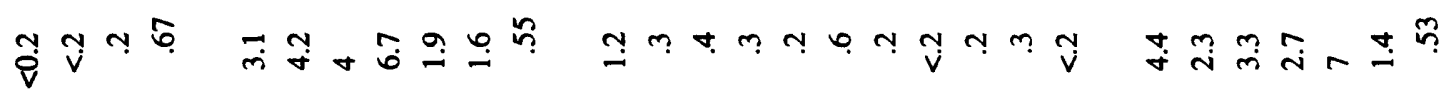

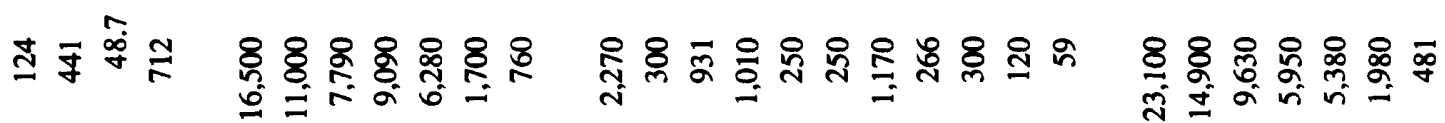

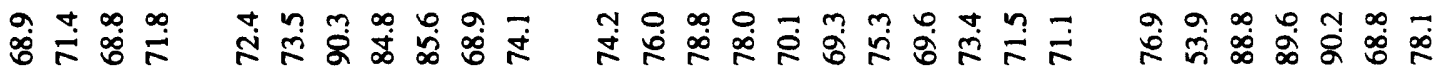

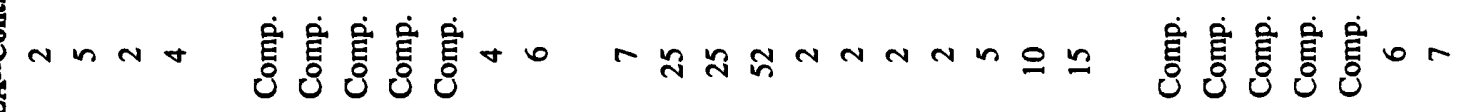

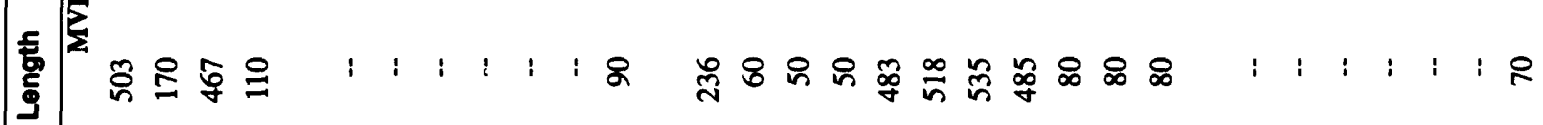

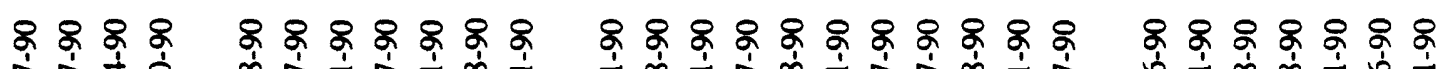

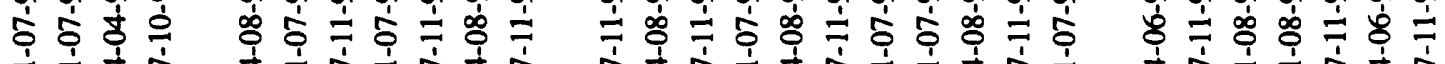

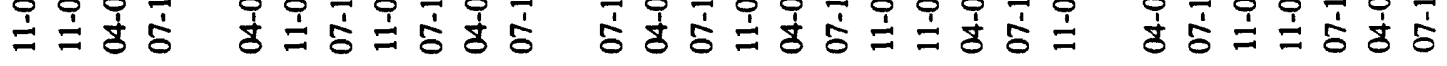

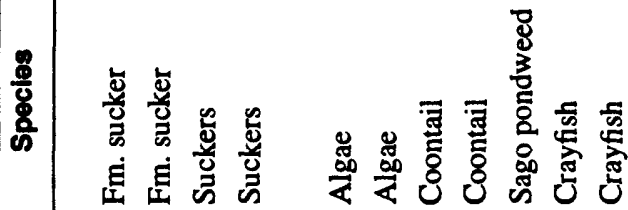
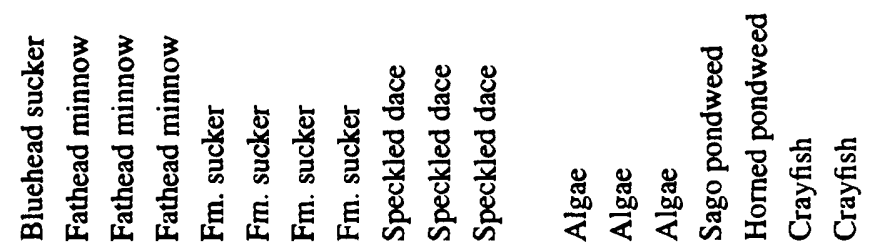

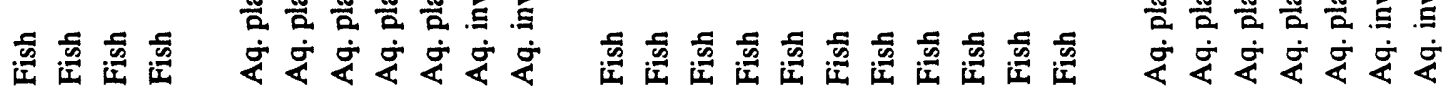

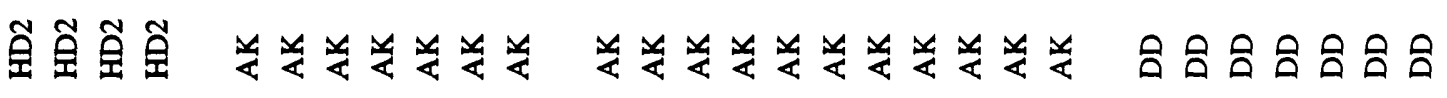




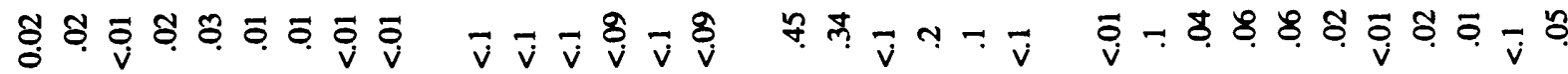

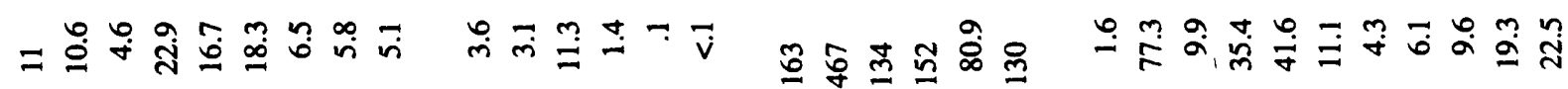

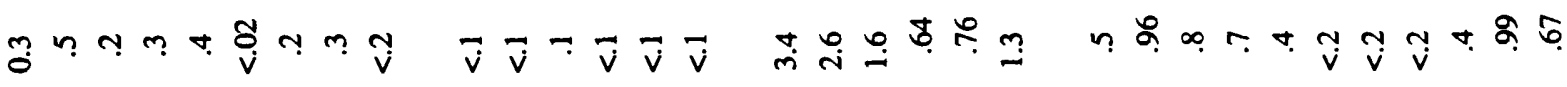

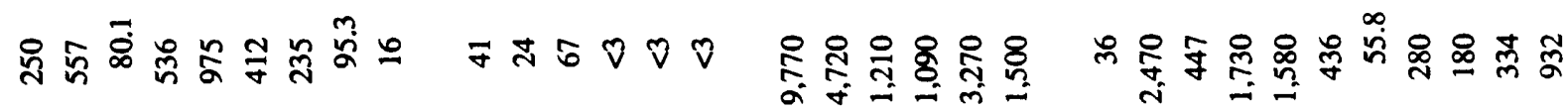

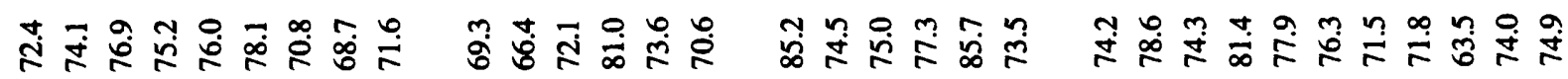

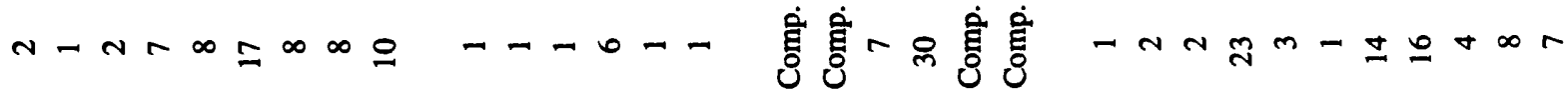

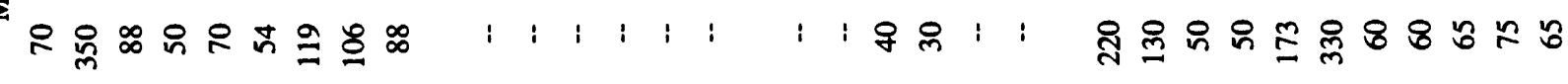

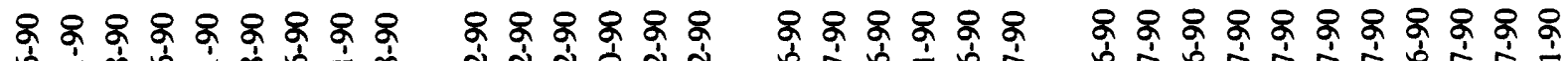

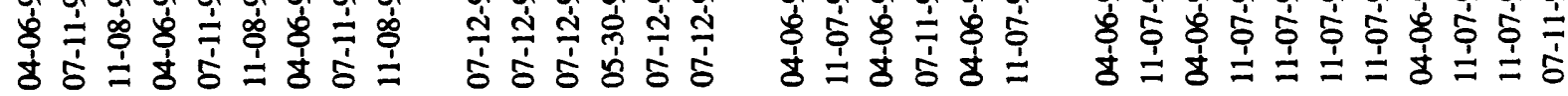

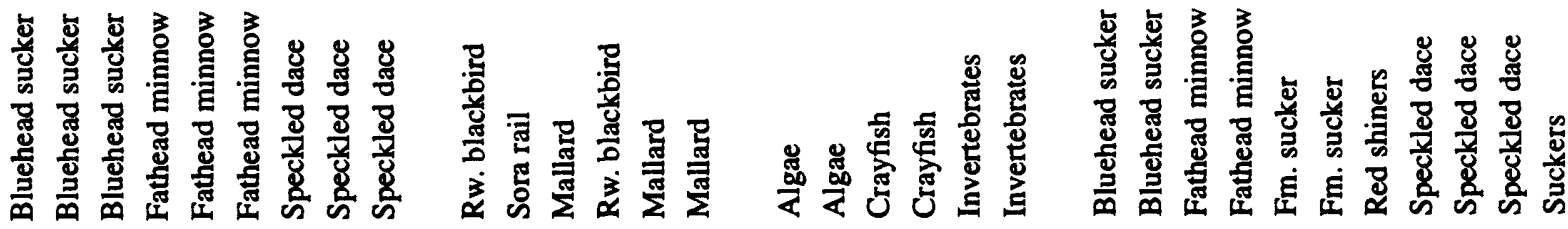

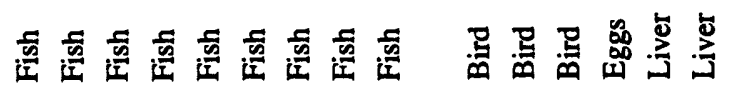

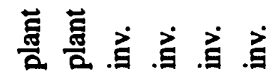
安要安安要安

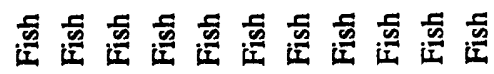




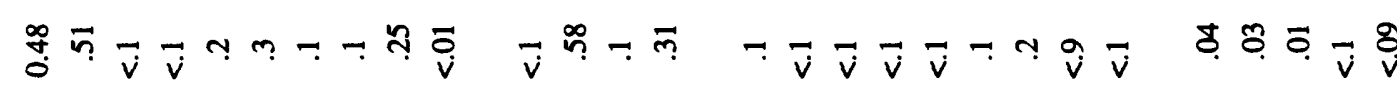

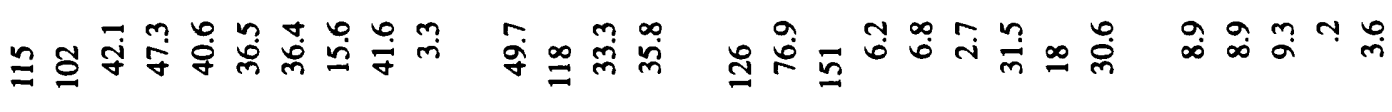

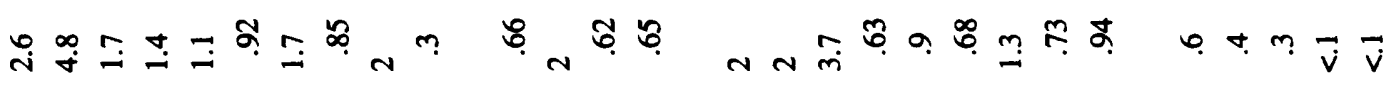

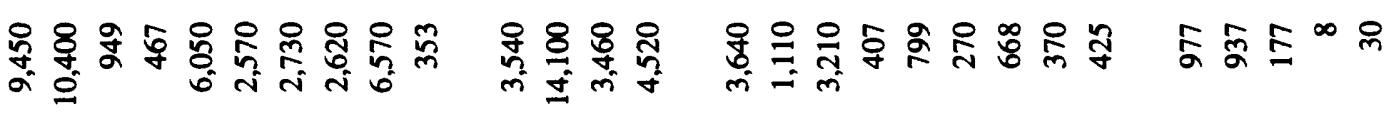

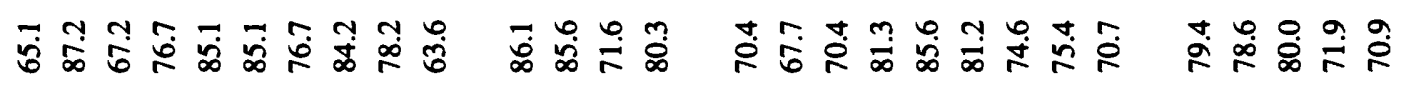

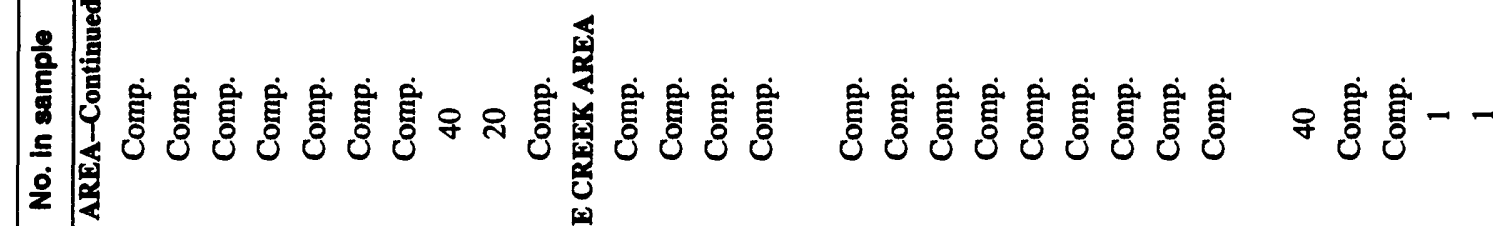

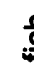
$1: 1: 1: 1988$

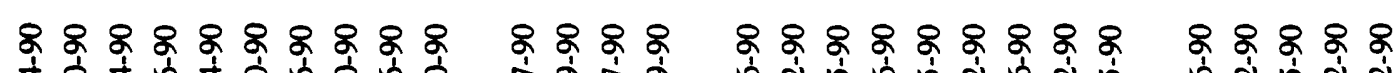

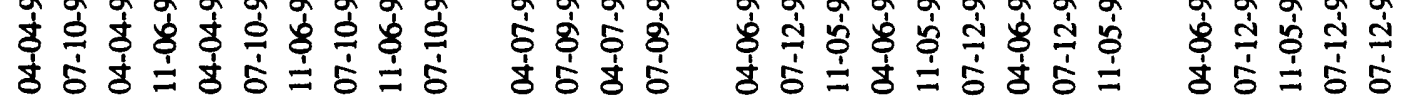

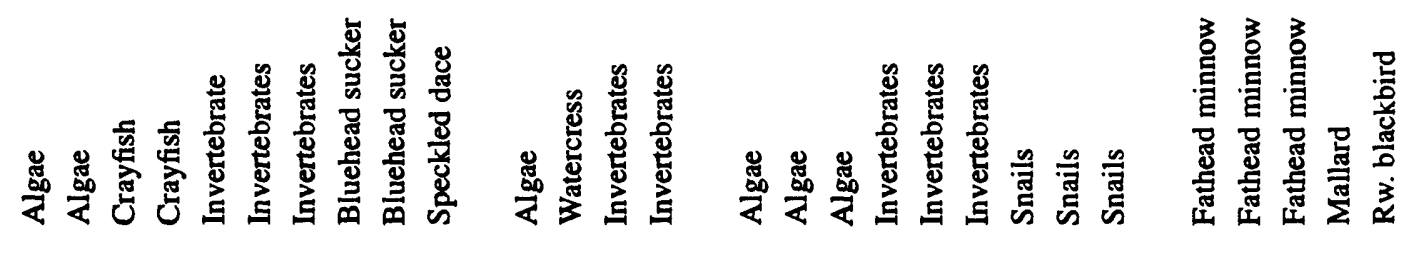

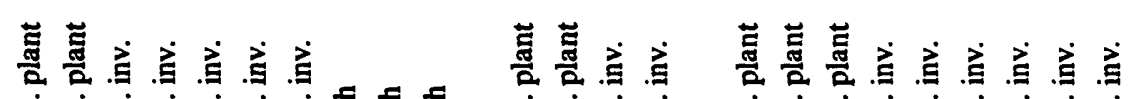

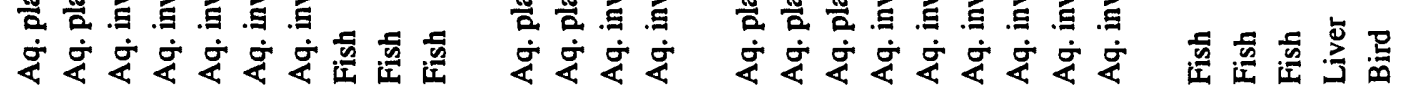

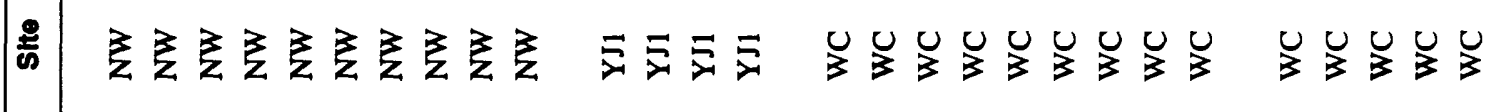


ஜூ

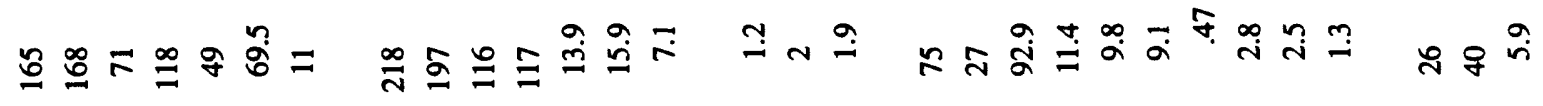

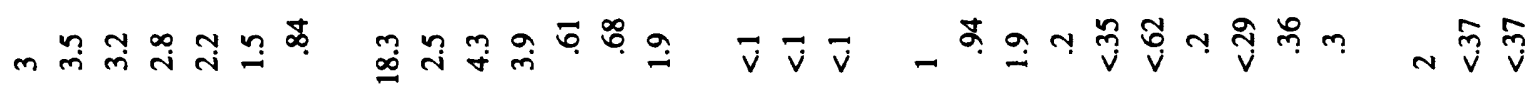

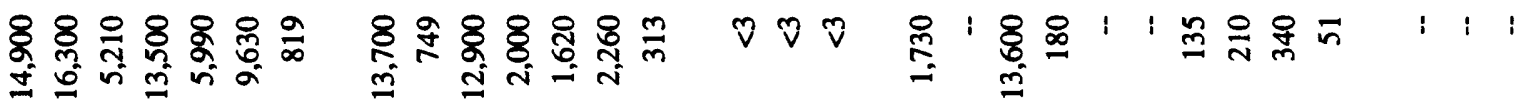

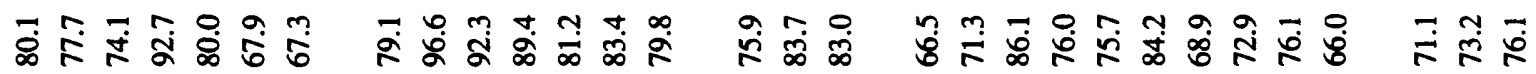

ن்

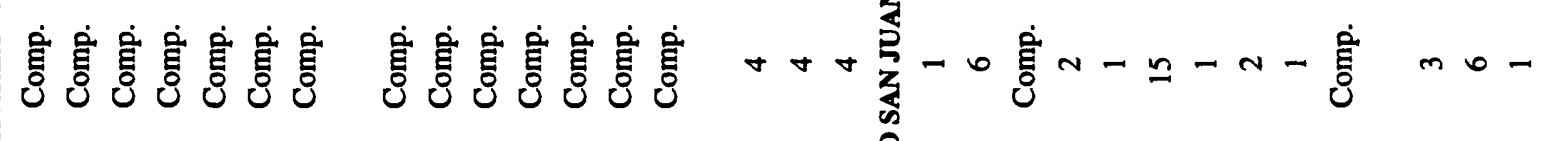

$: \quad 1 \quad: \quad: \quad 1 \quad 1 \quad 1$

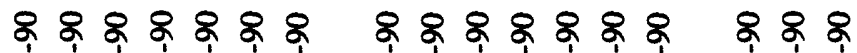
ஸิ่

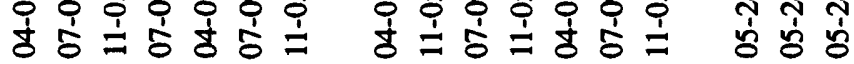

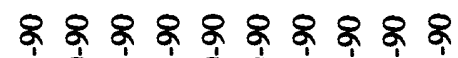
ปे่

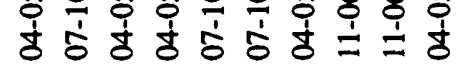

요 \& 8 눙은 过

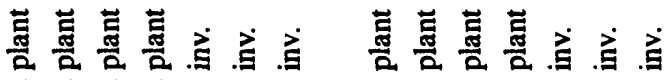
安安安安安安安 安安安安安安安

品品竞宣宣

舟垔幽 


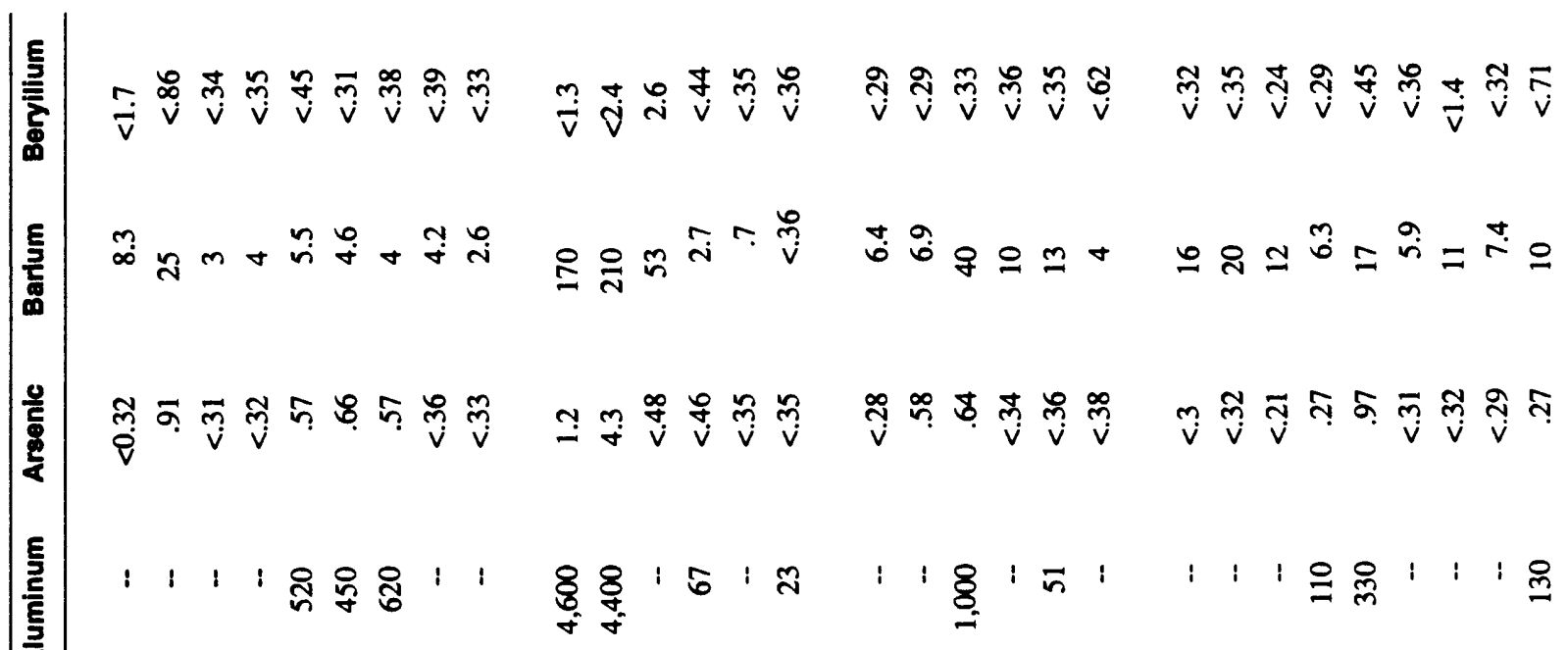

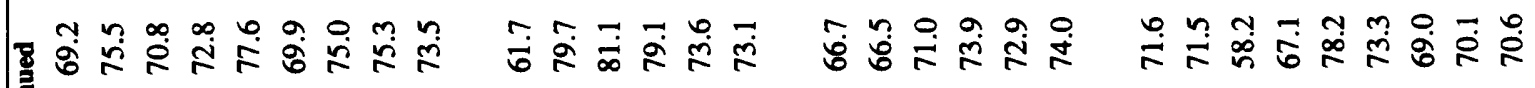

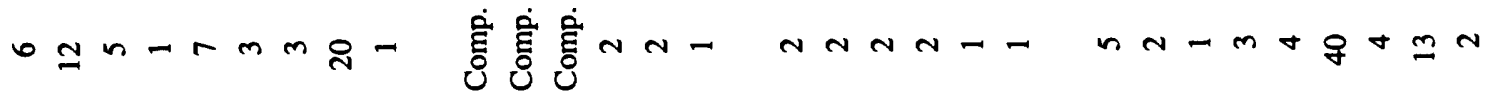
i

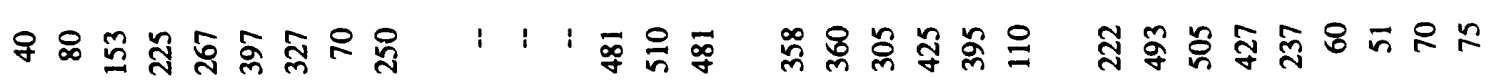
要

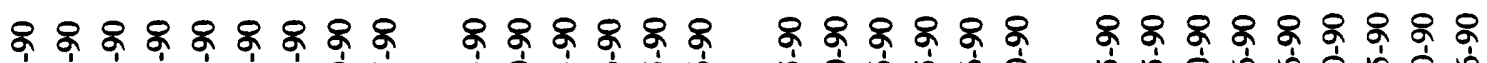

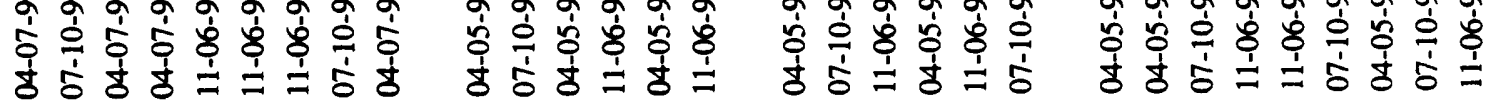

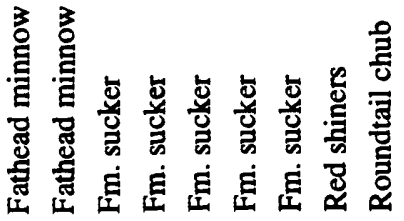

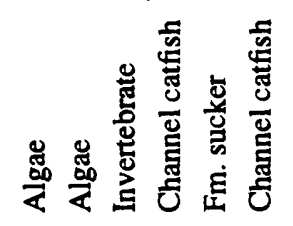

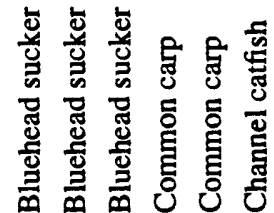

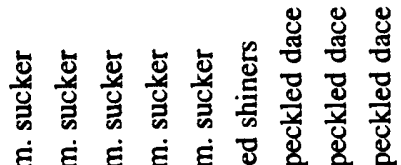

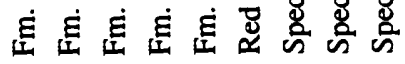

壱壱离

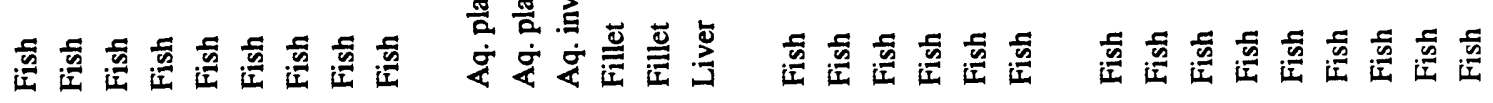

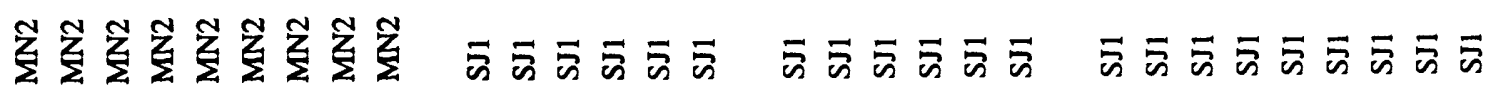




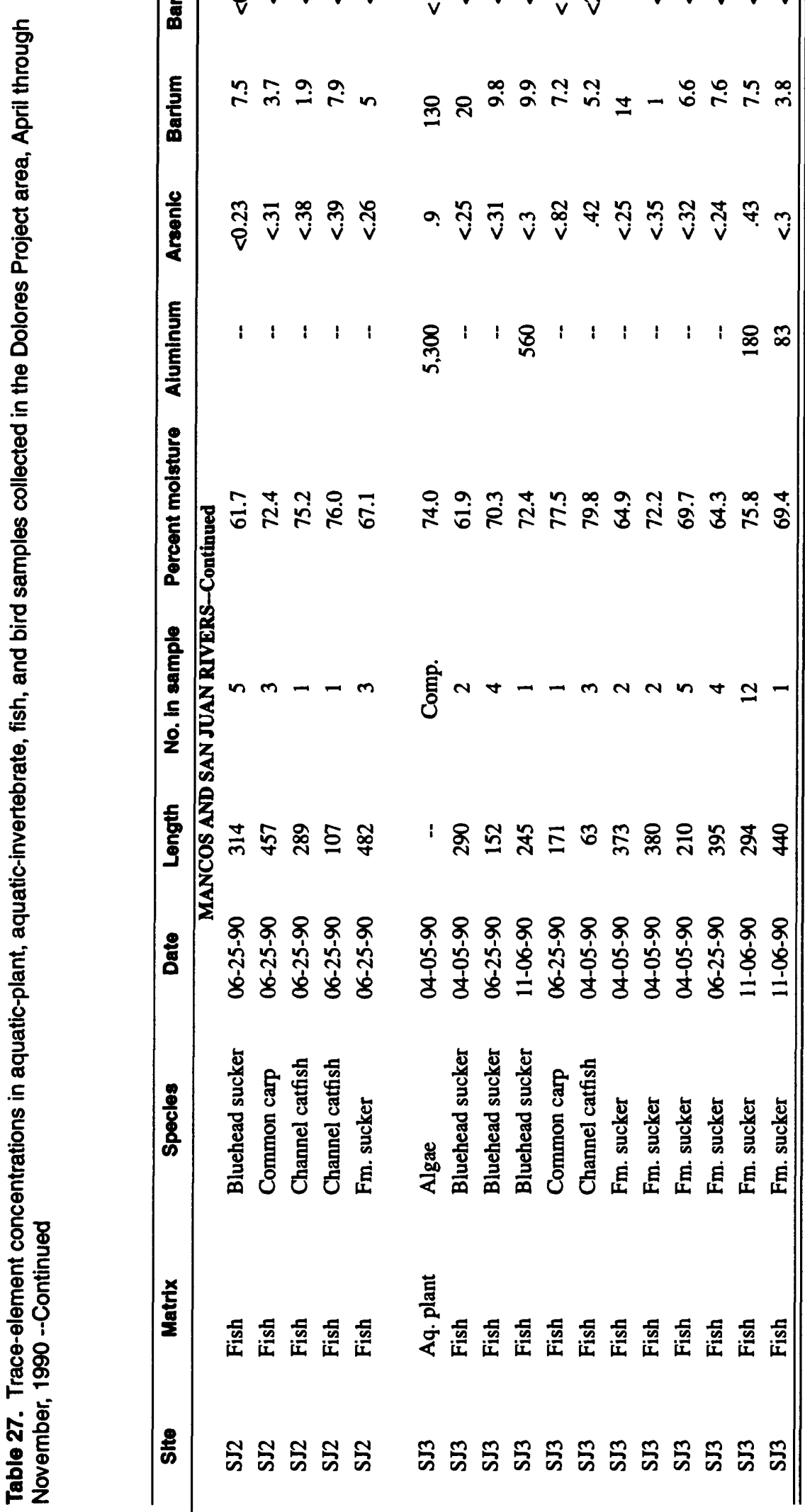

98 Reconnaissance Investigation of Water Quality, Bottom Sediment, and Biota Associated with Irrigation Drainage in the Dolores Project Area, Southwestem Colorado and Southeastern Utah, 1990-91 


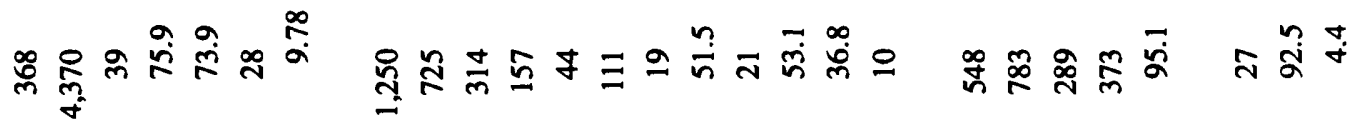

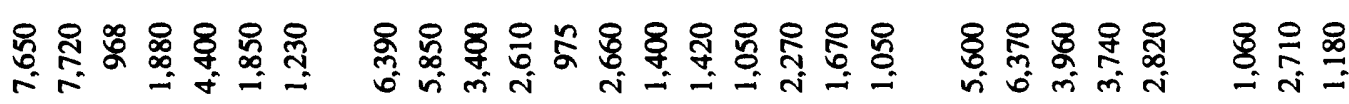

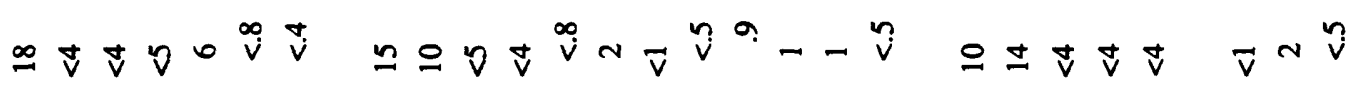

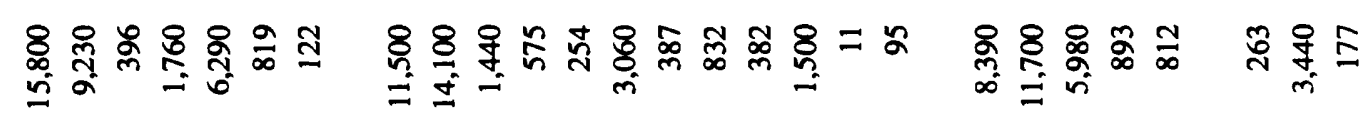

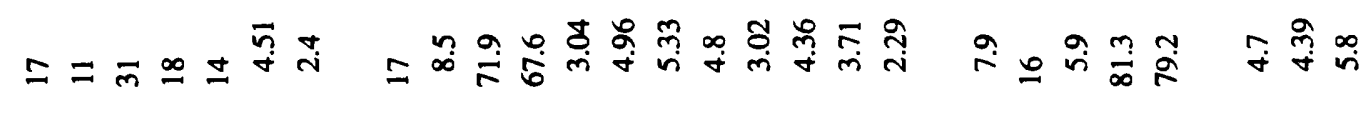
递

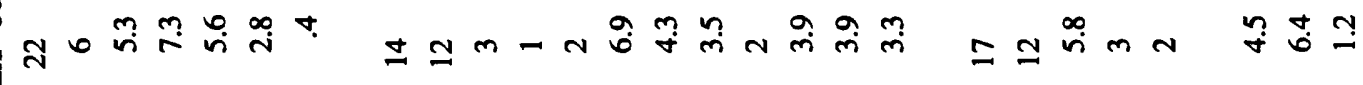

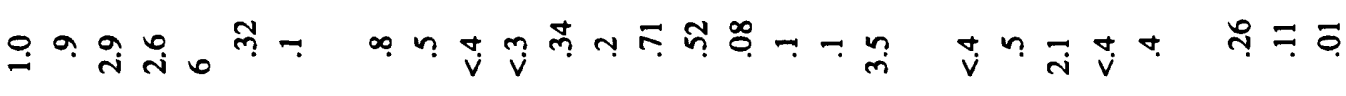

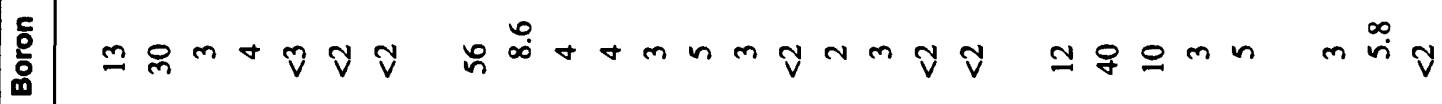

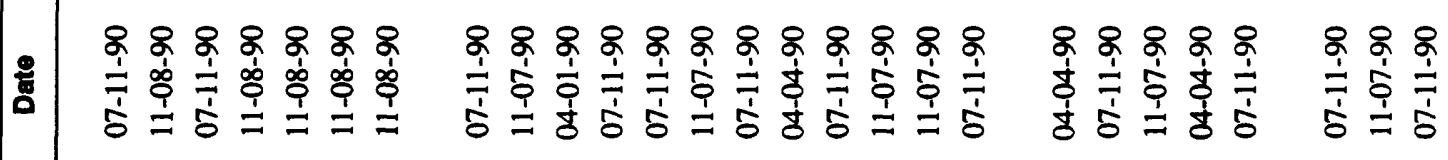

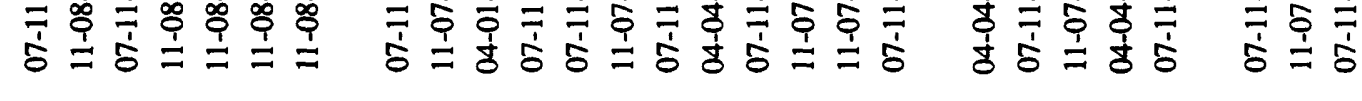

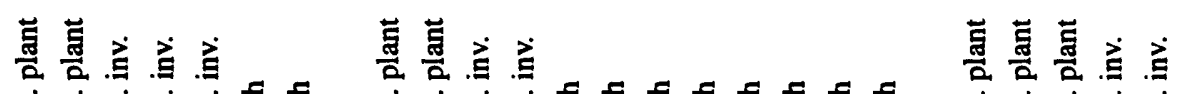

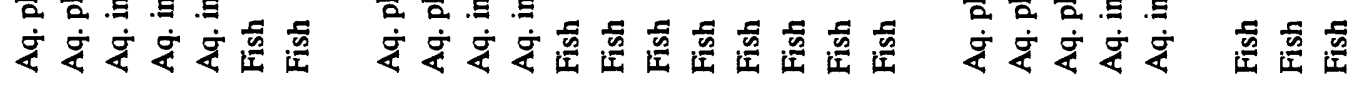

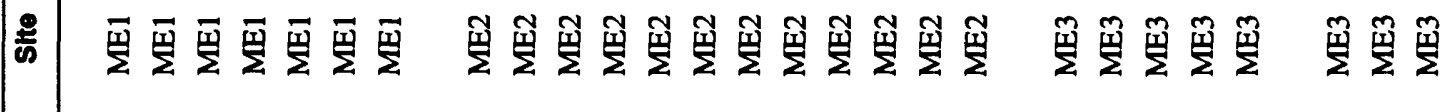


我

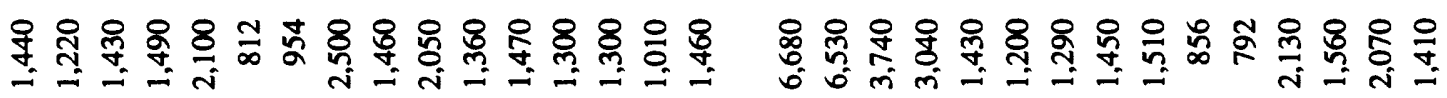

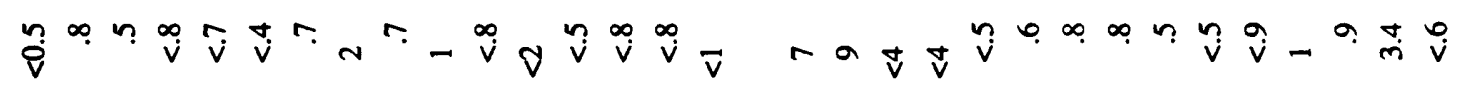

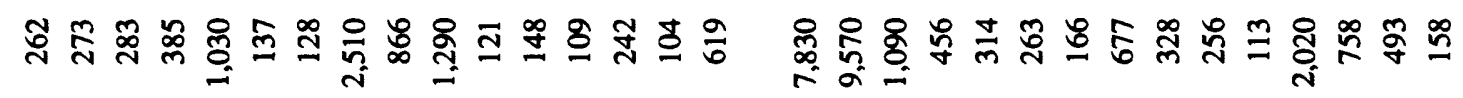

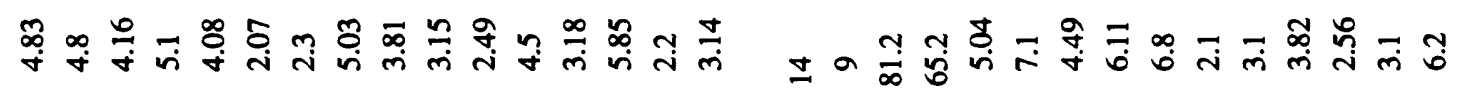
急

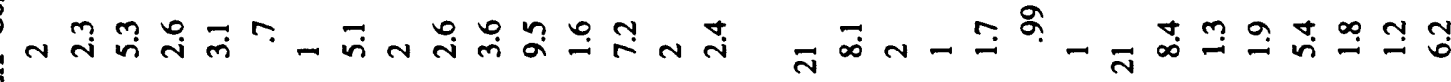

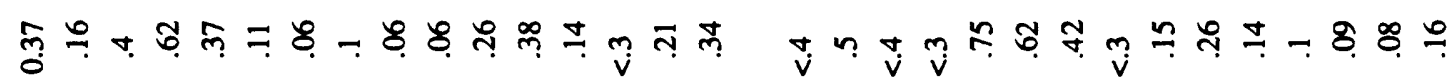

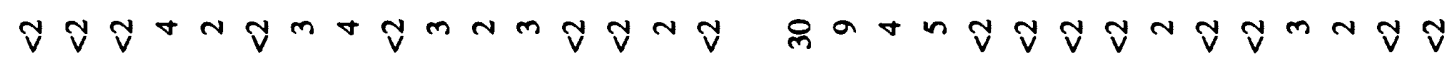

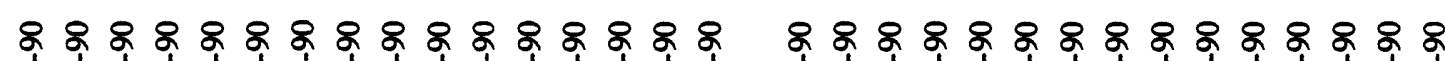

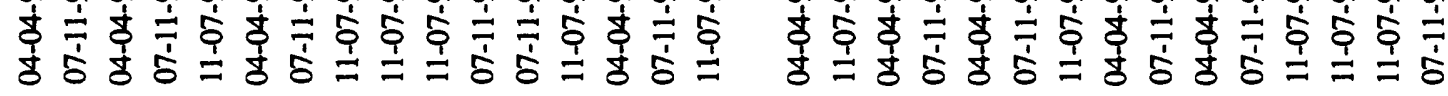

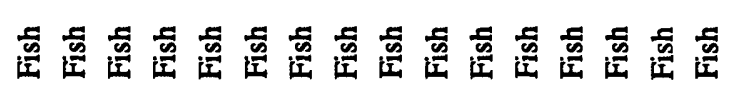

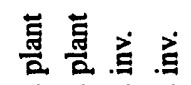

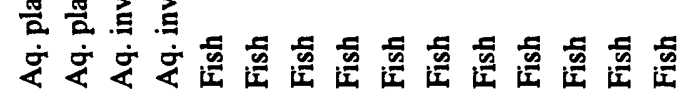

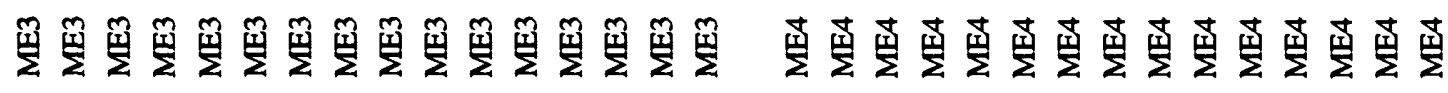




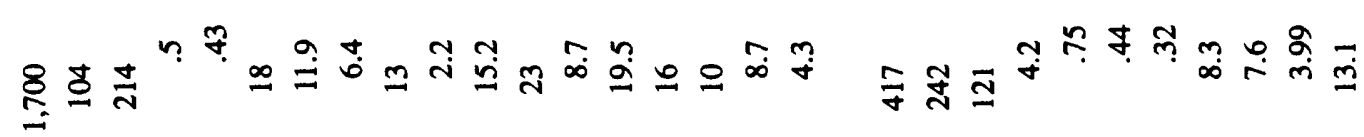

운 8

古生 $\vartheta$

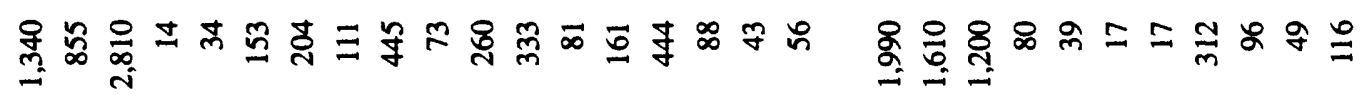

๓

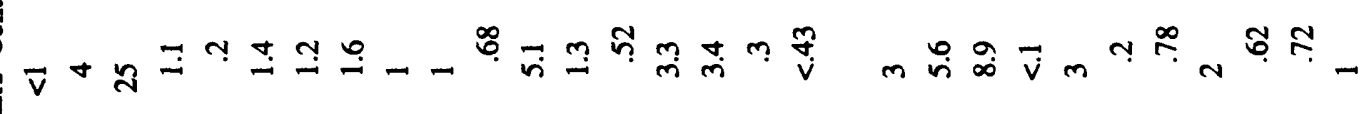

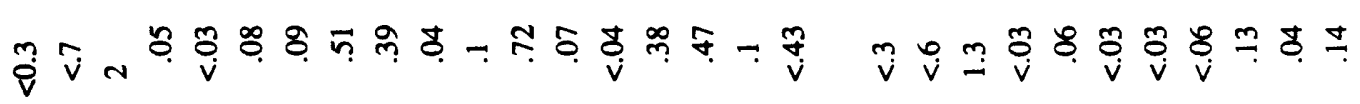

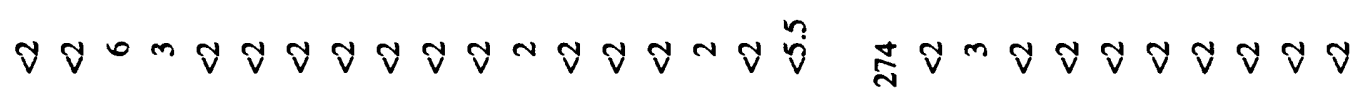

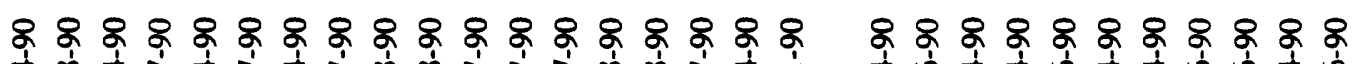

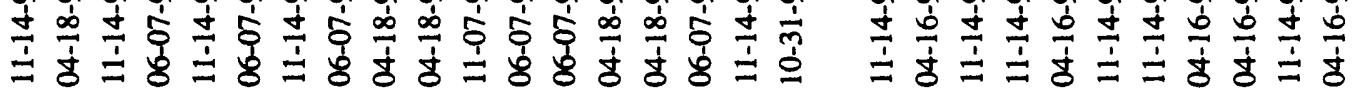

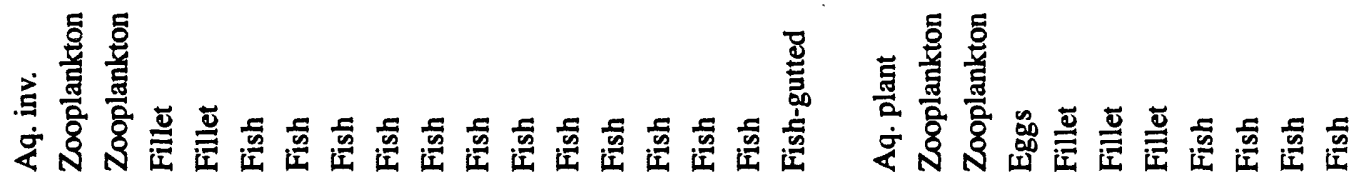

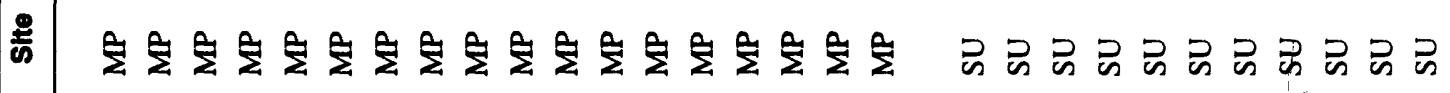


䓅

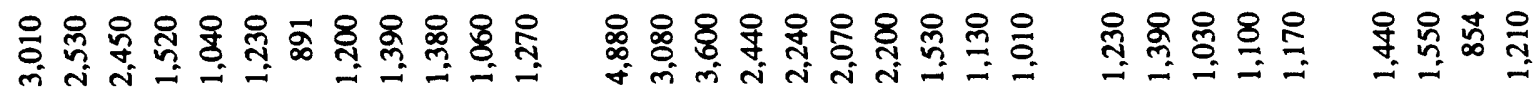

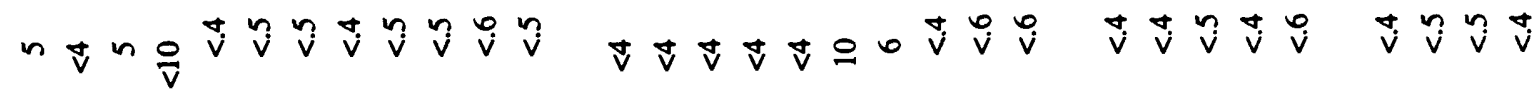

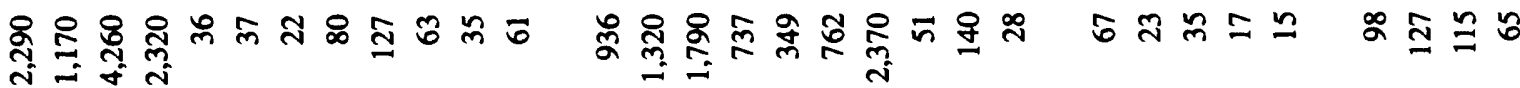

₹

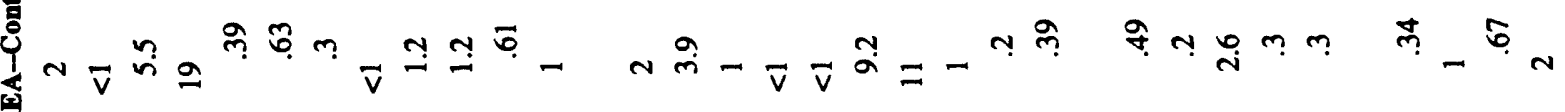

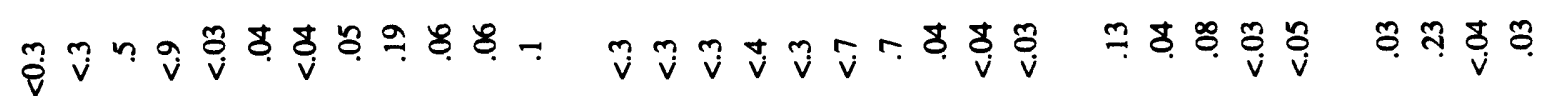

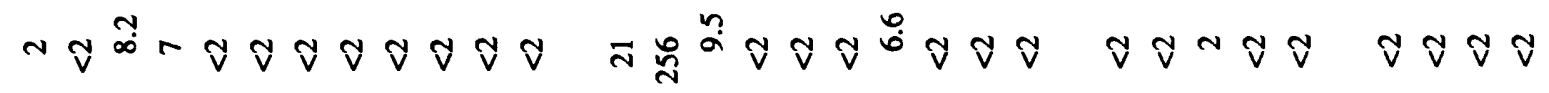

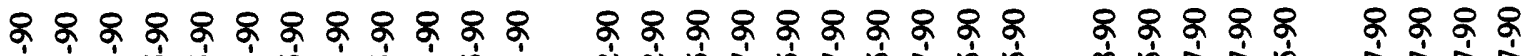

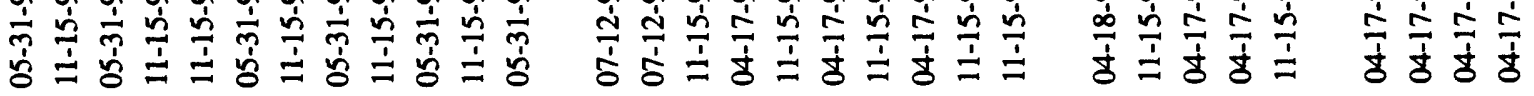

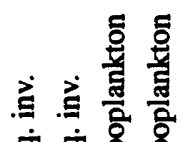

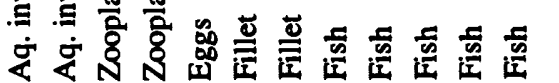

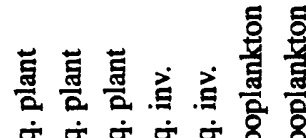

安安安安安家

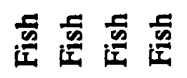

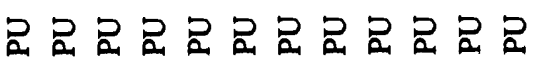

$E E E E E E E E E E$

$E E E E E$

$E F E E$ 


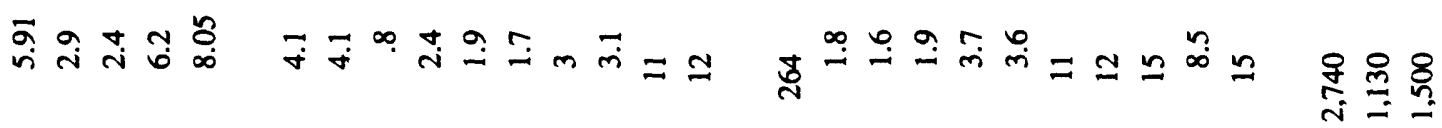

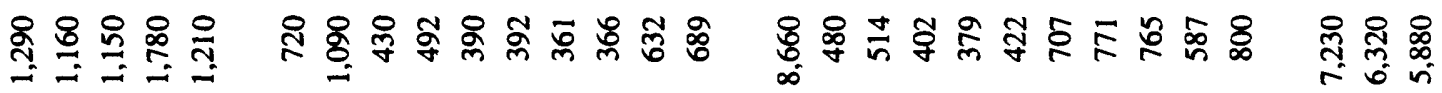

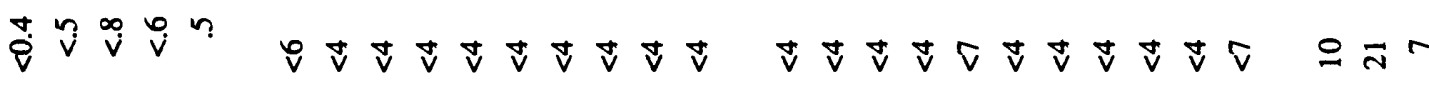

网

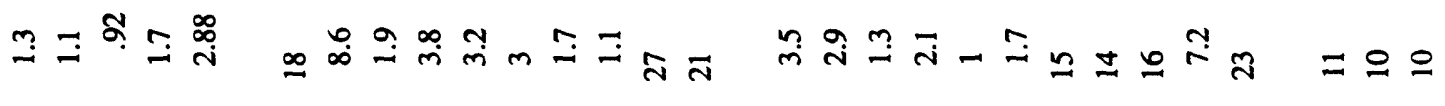

(1)

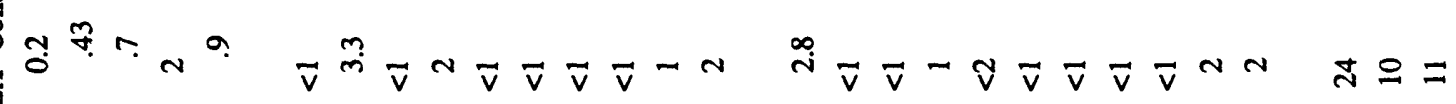

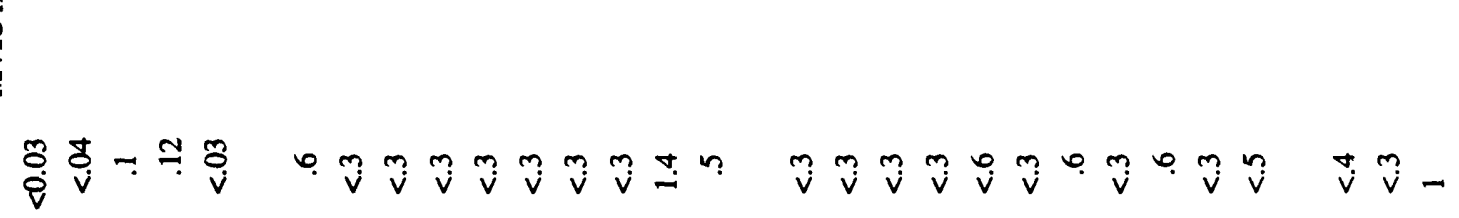

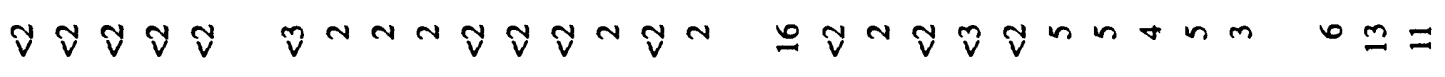

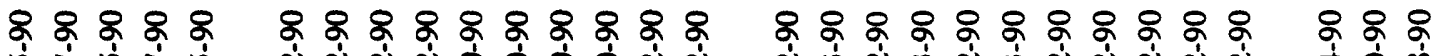

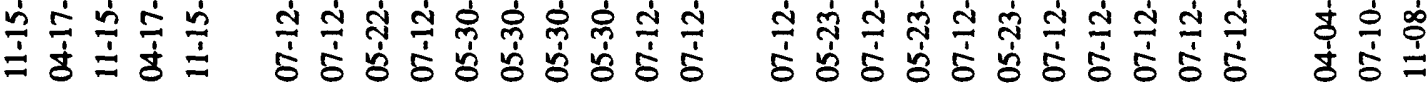

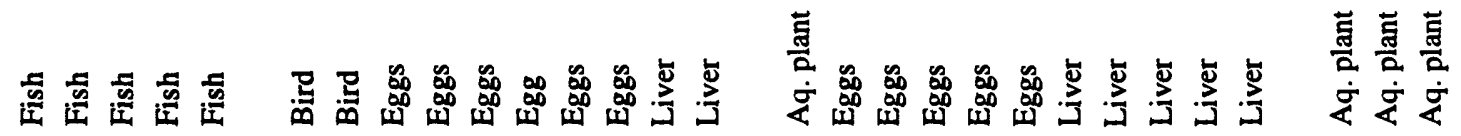

ํㅡㄹ 


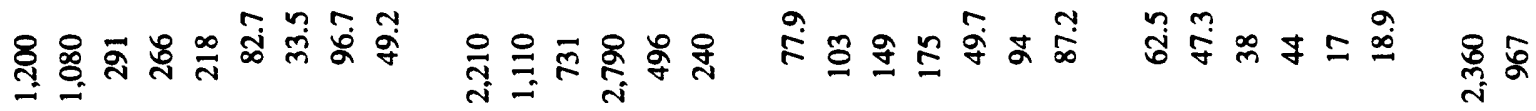

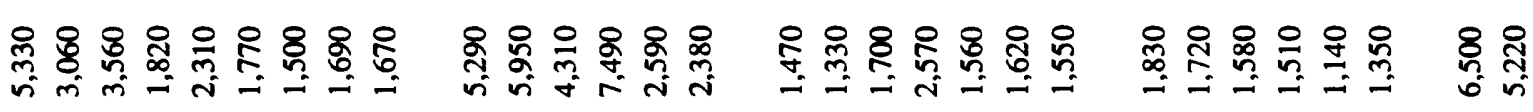

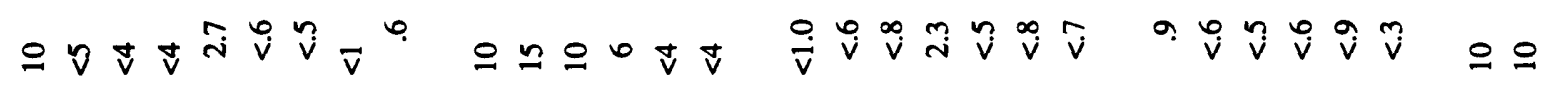

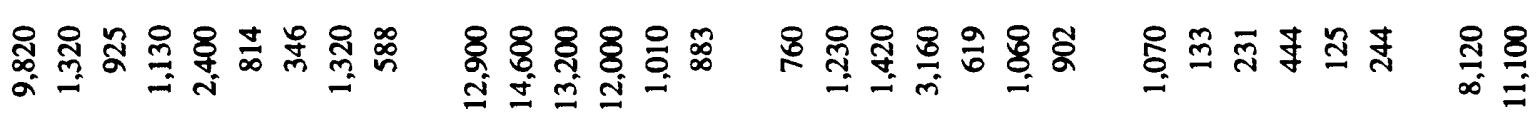

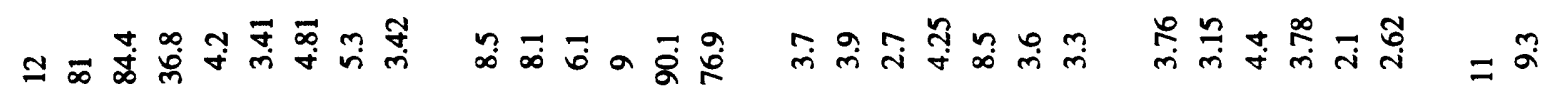
逢

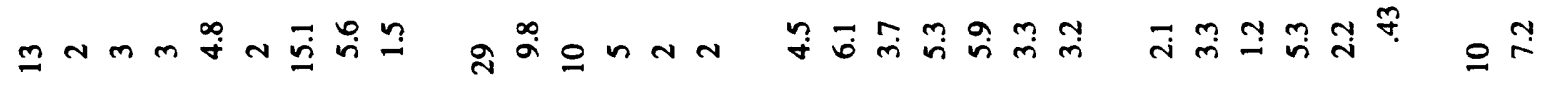

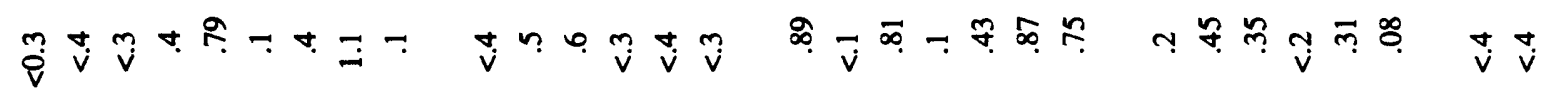

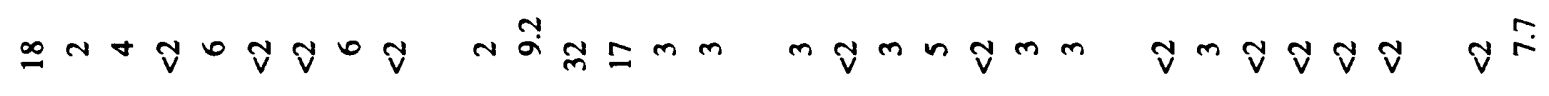

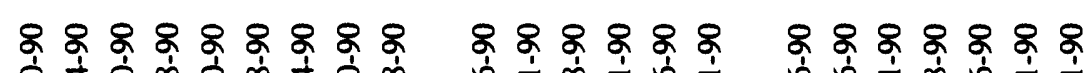

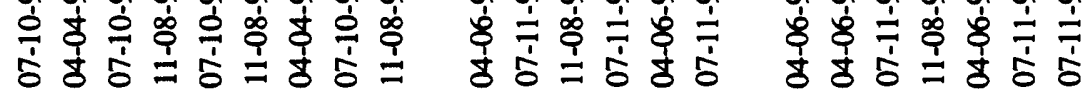

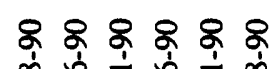

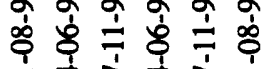
88

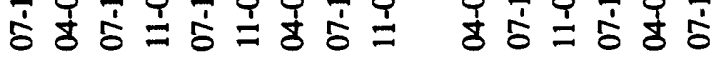

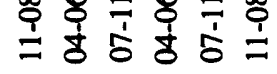
夏高

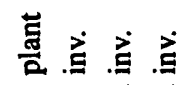

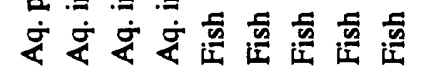

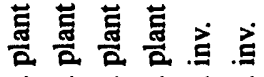
安要要安要要

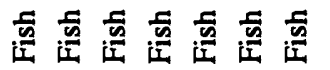

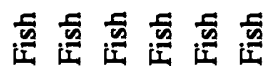
壱蒙 安安

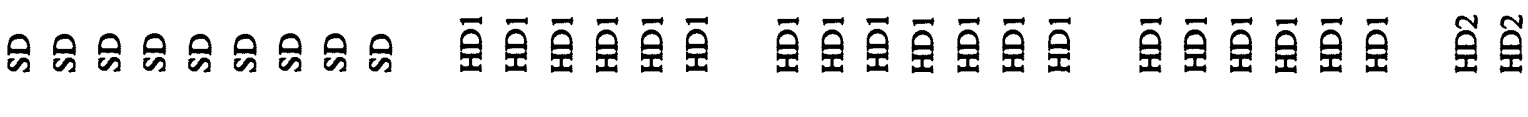


๙

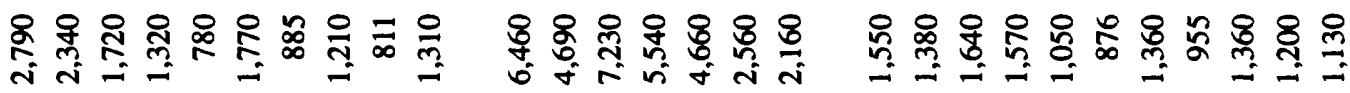

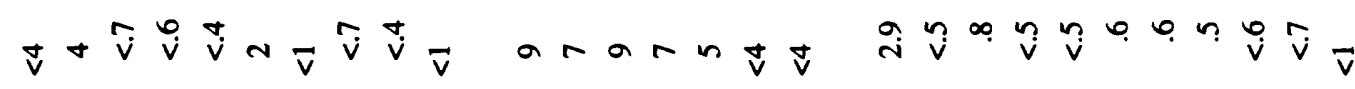

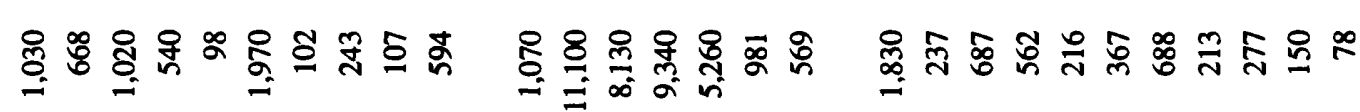

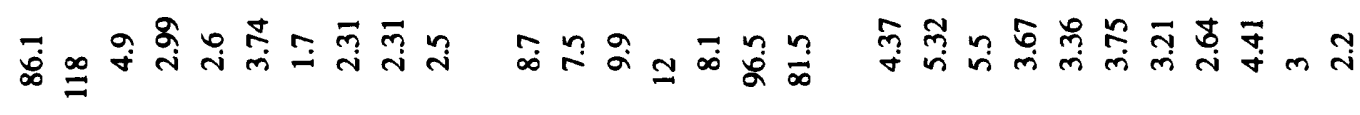

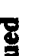

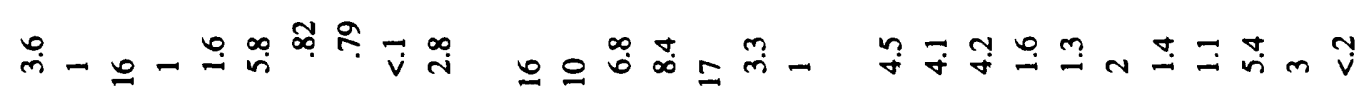

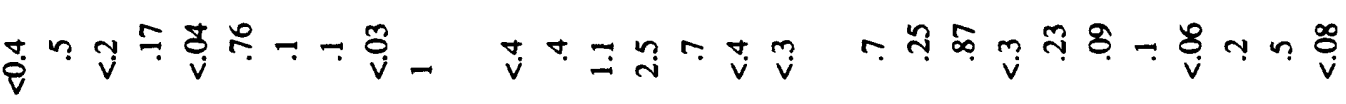

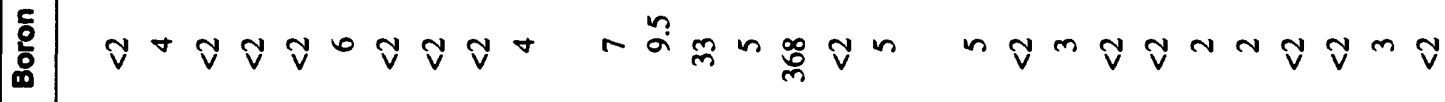

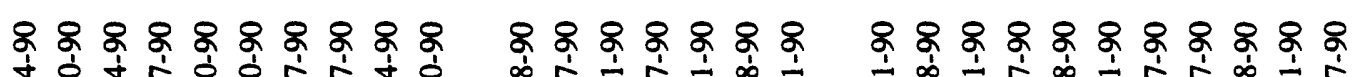

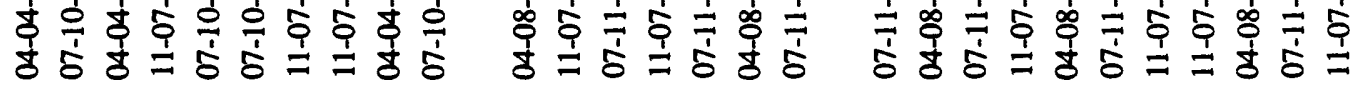

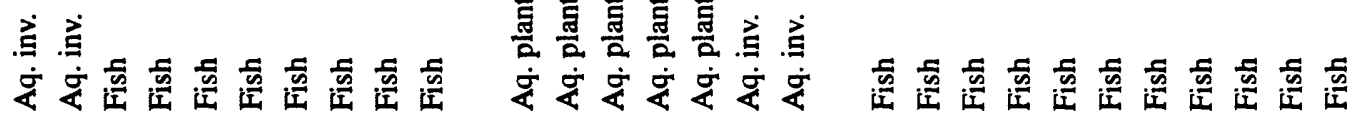

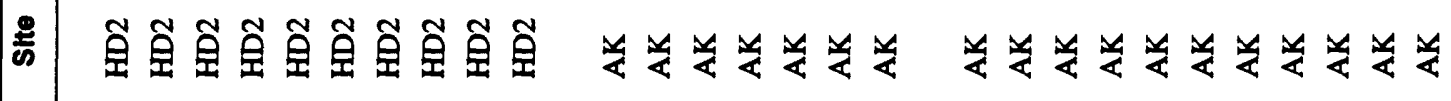




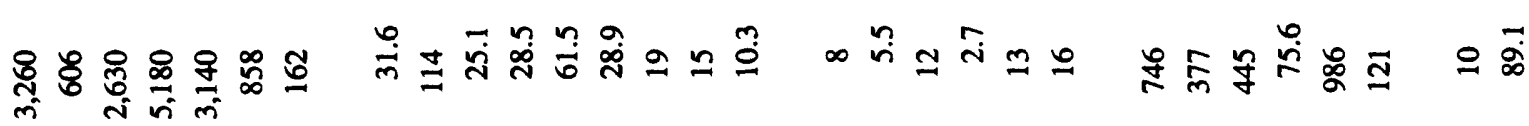

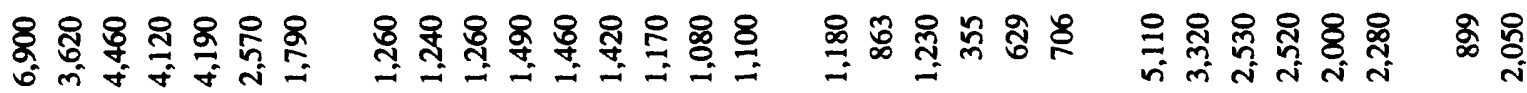

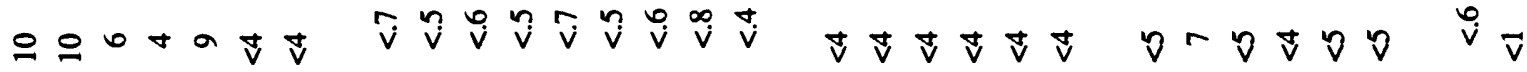

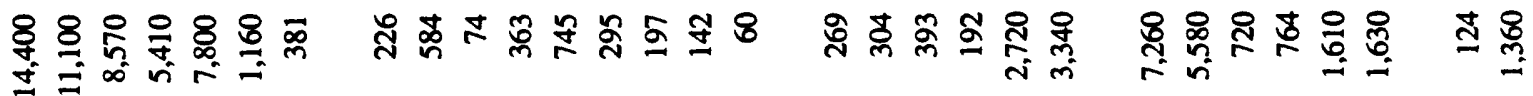

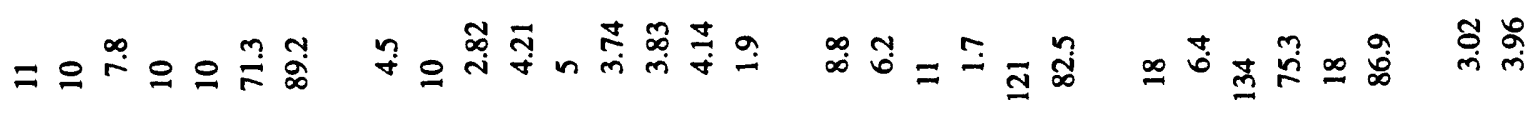
8

ก응

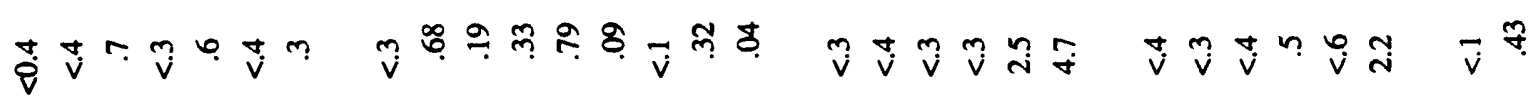
สิต

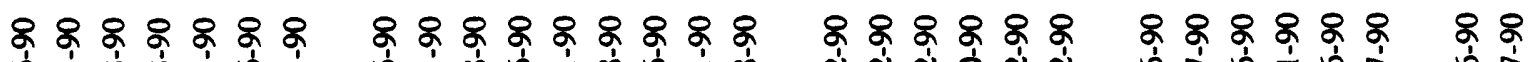

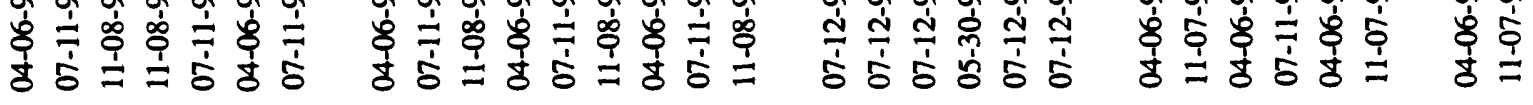




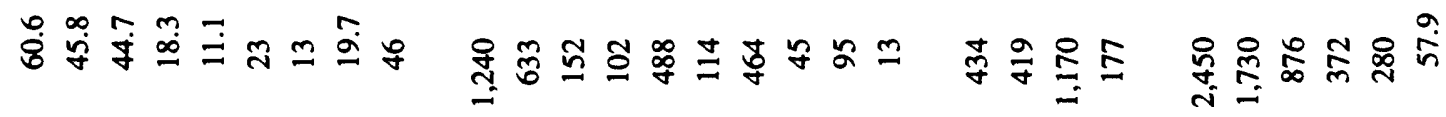

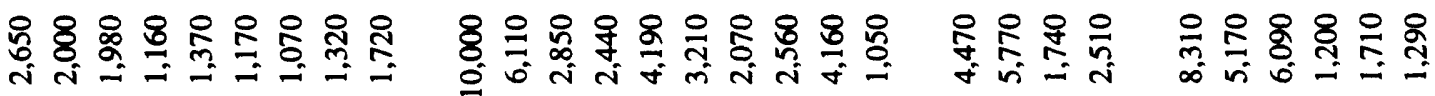

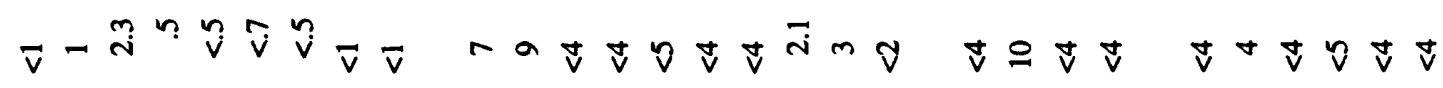

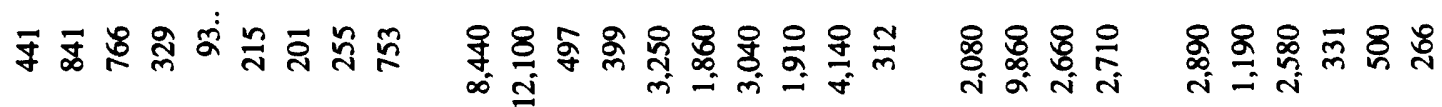

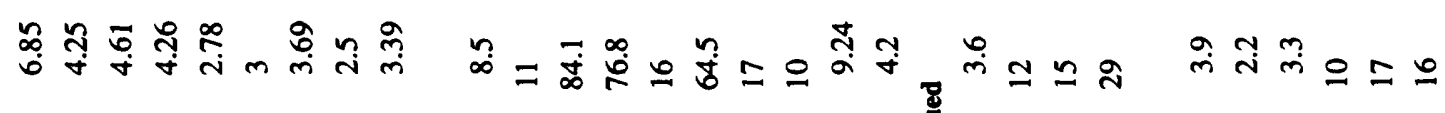

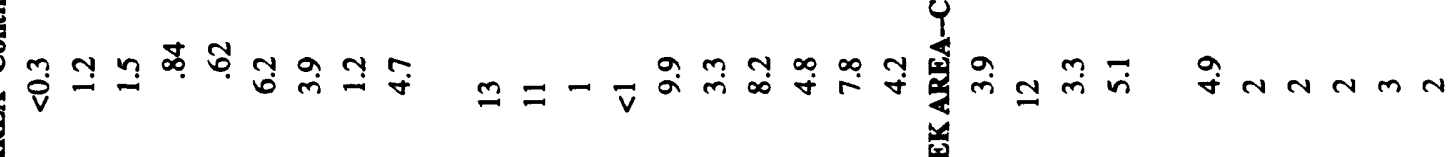

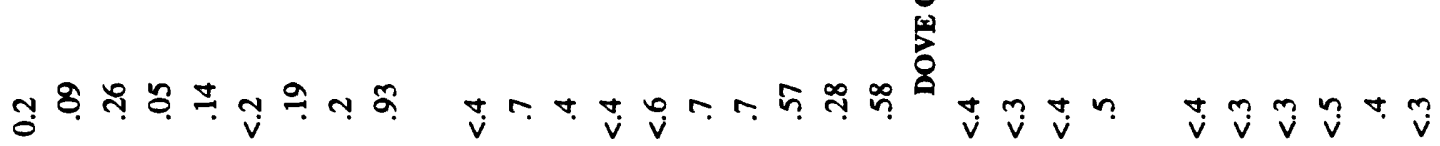

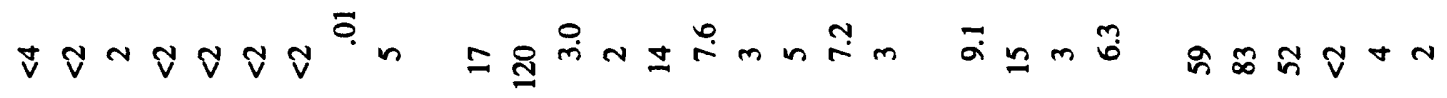

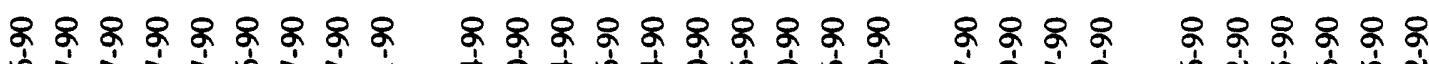

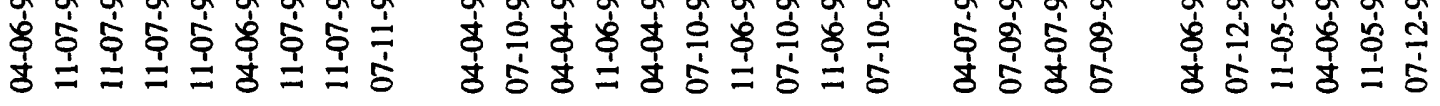

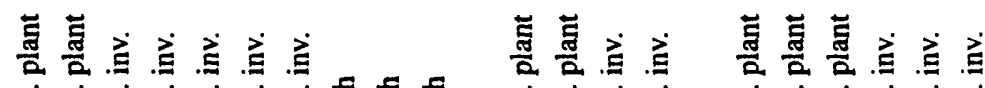

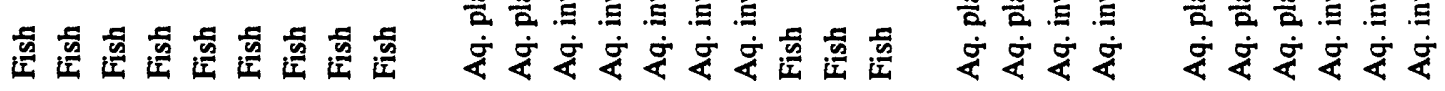

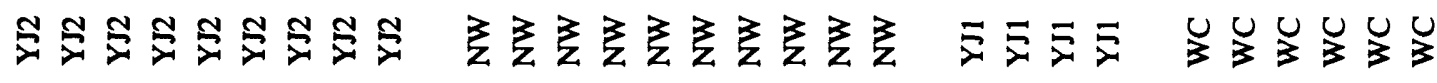




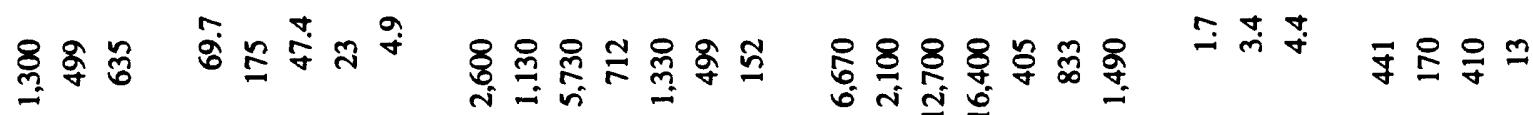

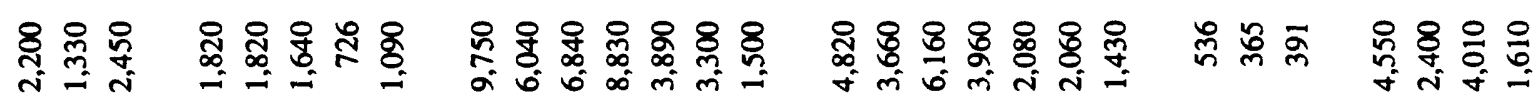

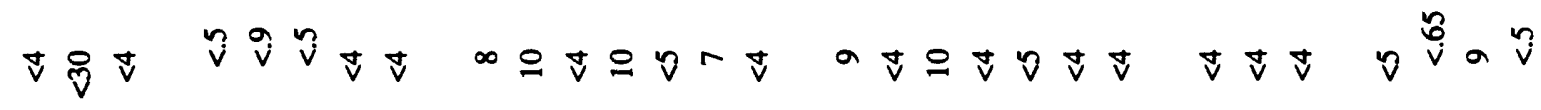

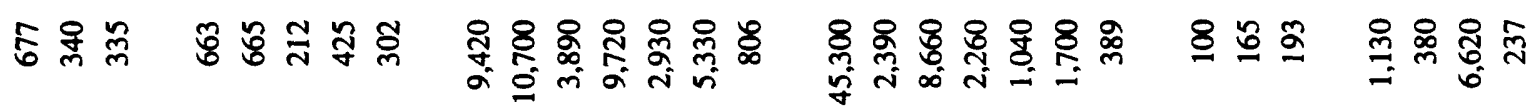

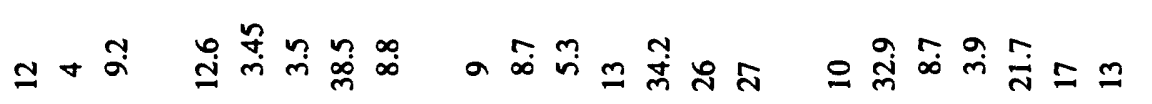

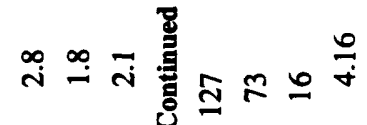

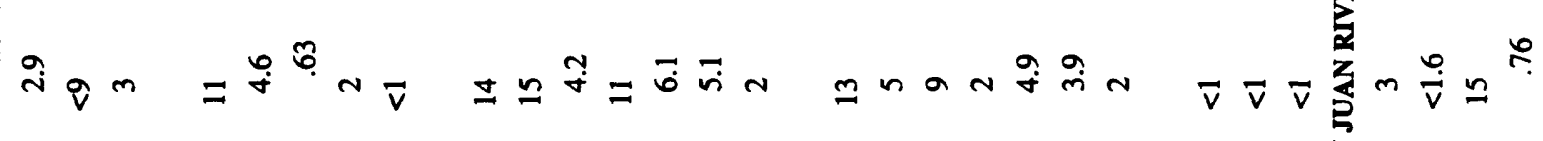
要 I. $\vartheta$

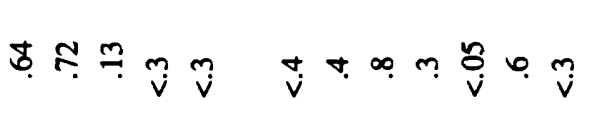

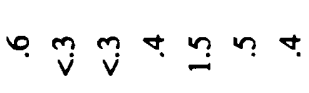
$m \rightarrow$

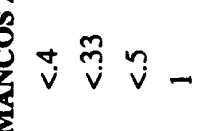

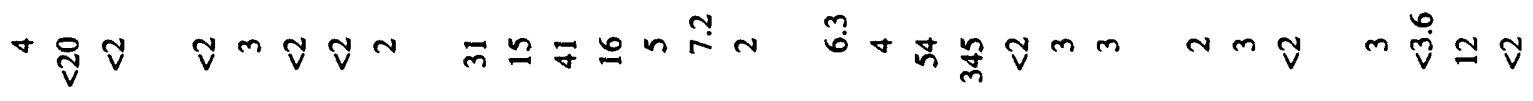

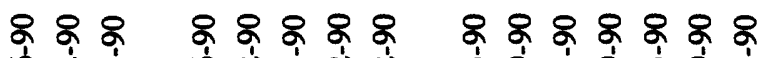
में

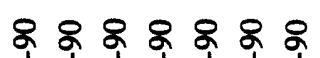
की $8 \% 8$ 8888 पे 古客产客客

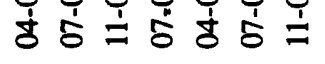

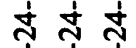
4่

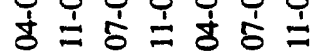
宛客安 就客高方

竞

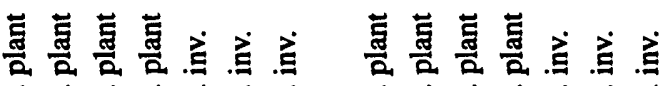

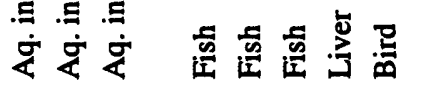
安安安安安安安 安究安安安要要

$\infty$ 总总总

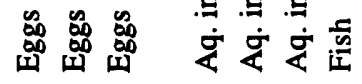

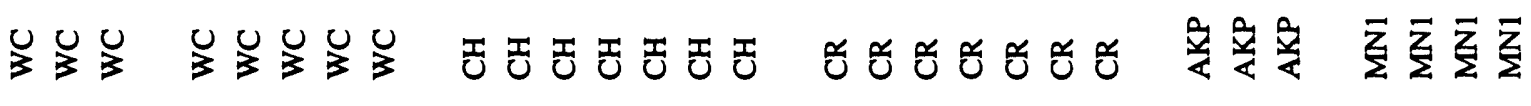


岛苟

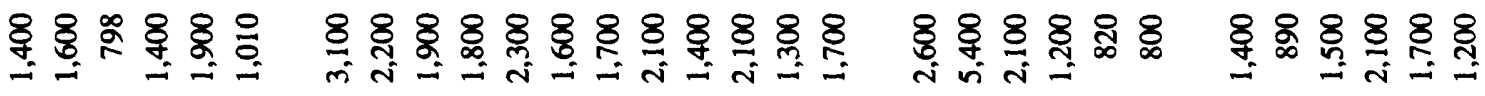

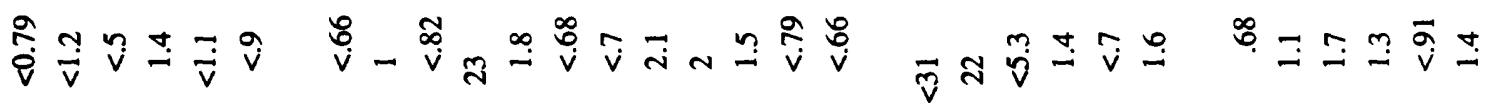

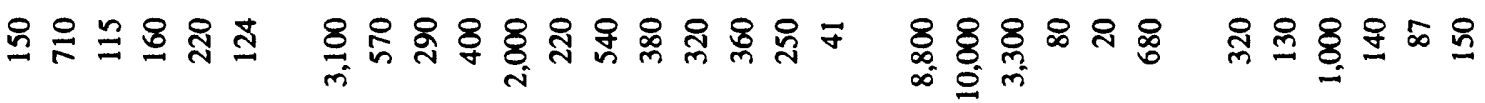

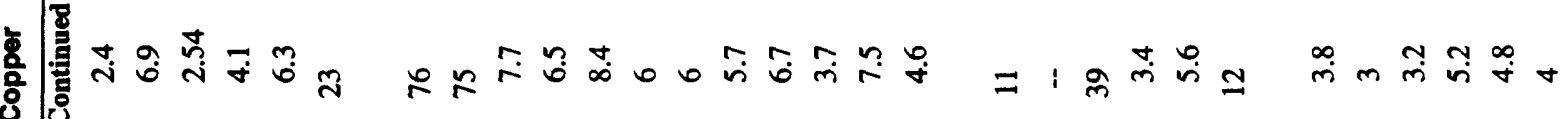

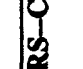

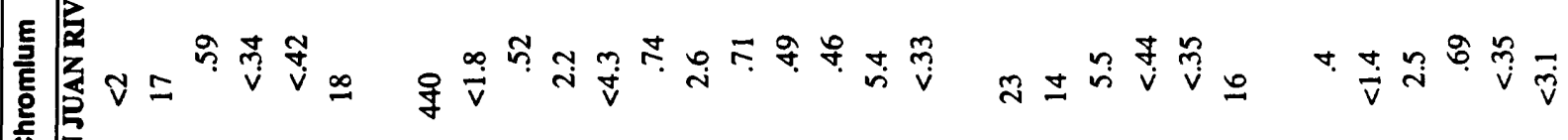

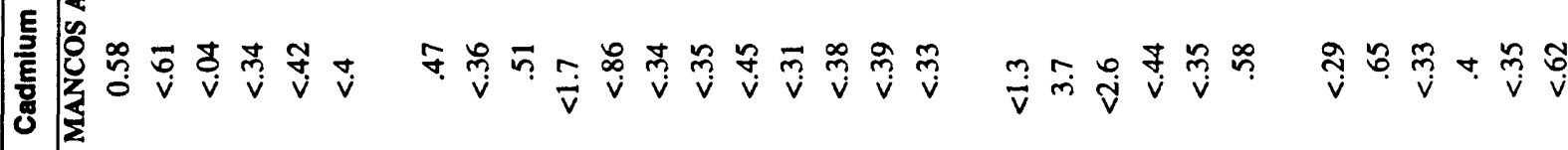

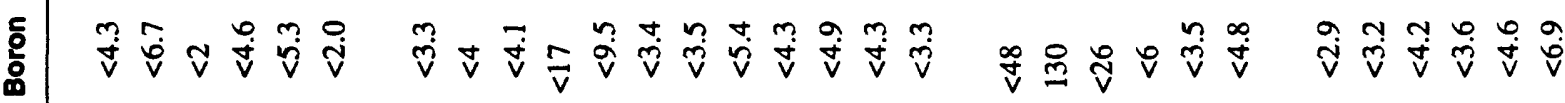

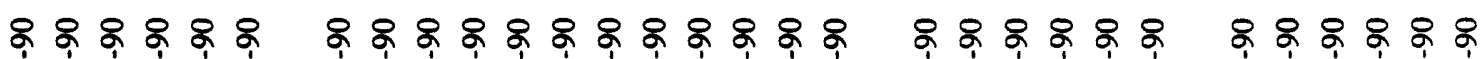

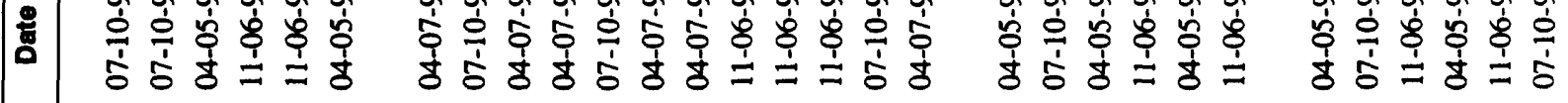

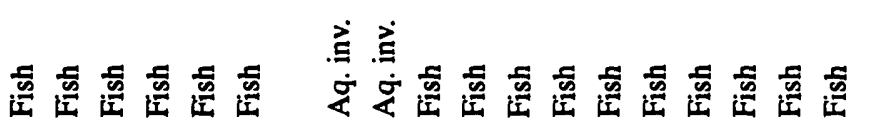

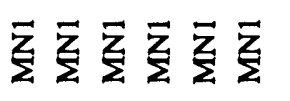

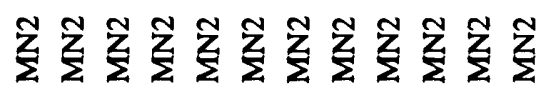

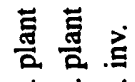

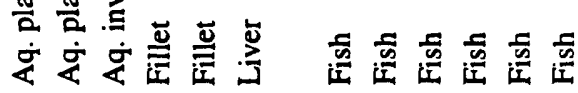

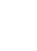




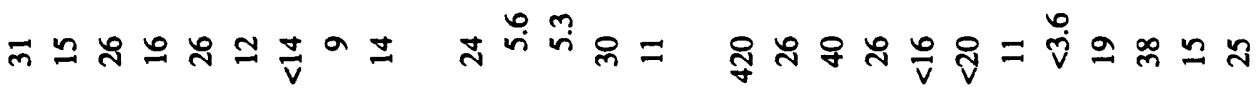

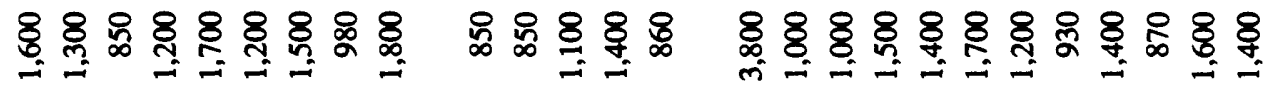

菅

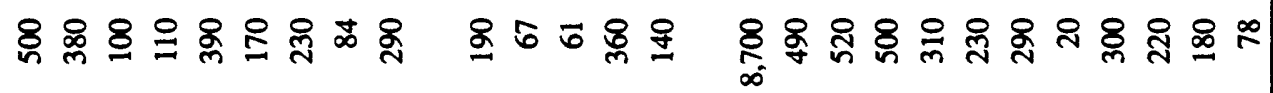

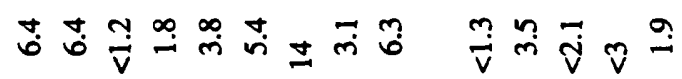

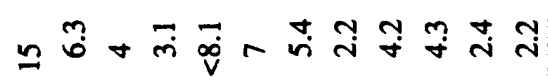

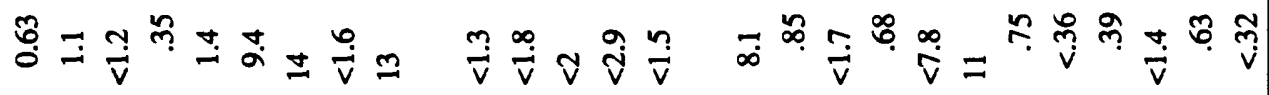
3

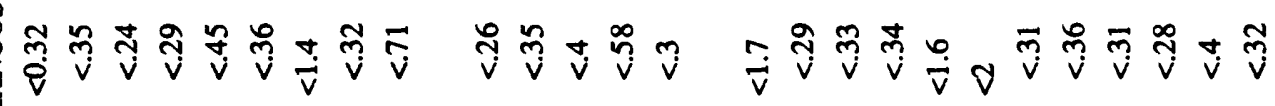

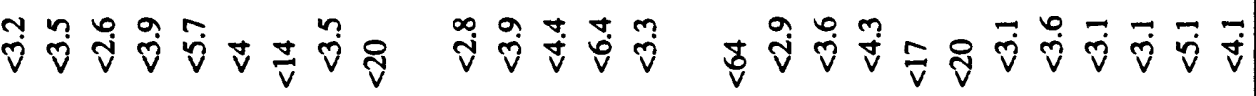

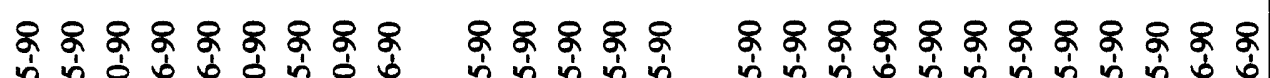
பें

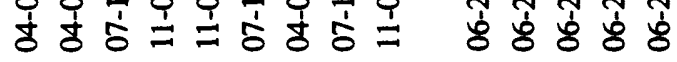

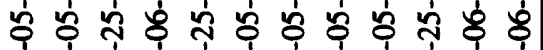

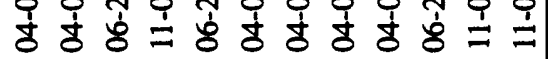

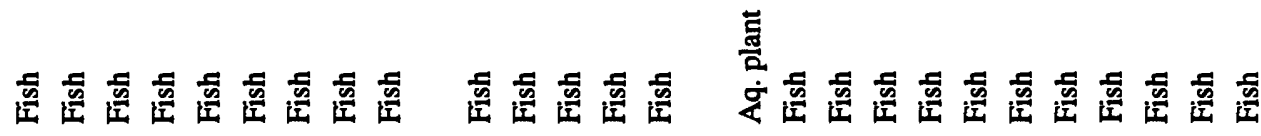

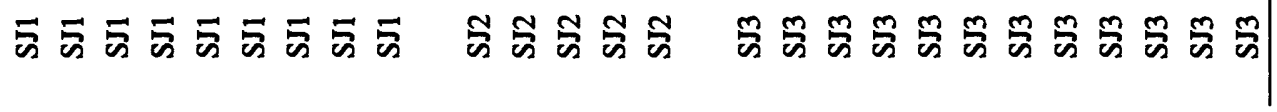




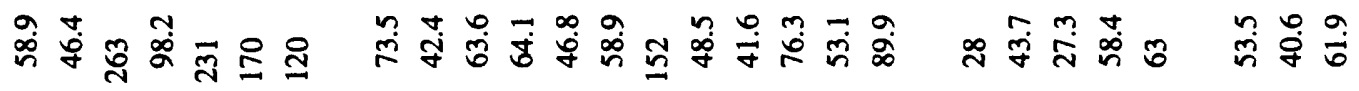

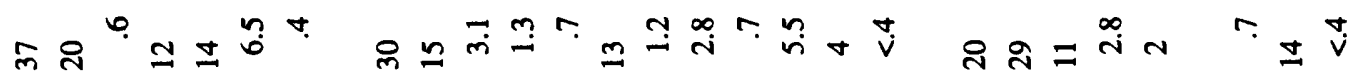

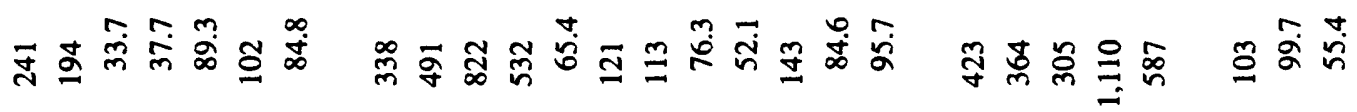

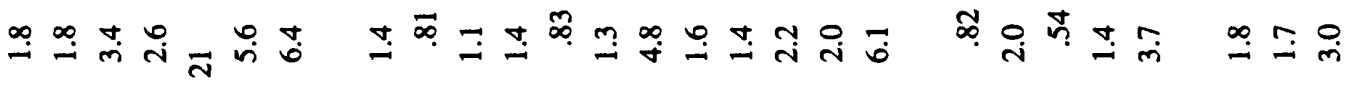

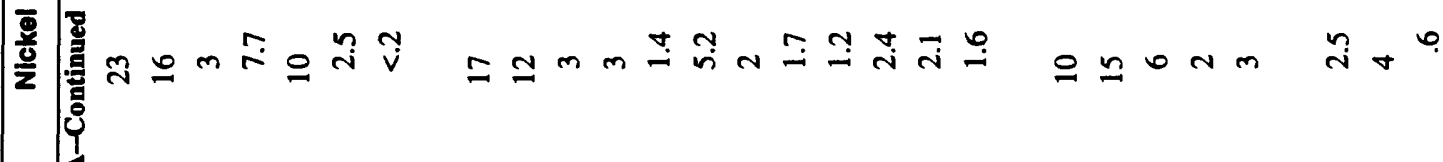

尊

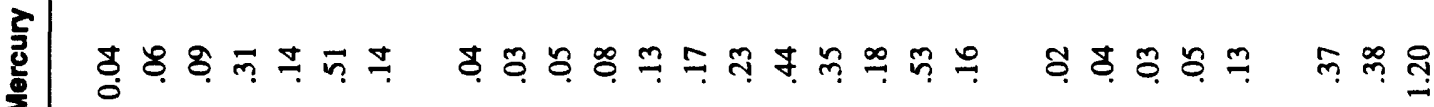

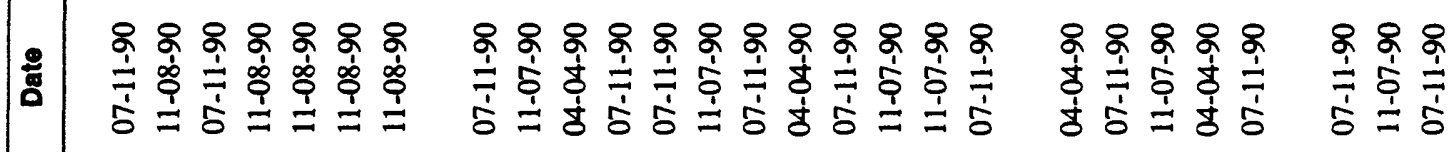

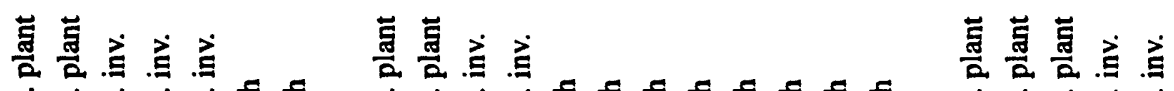

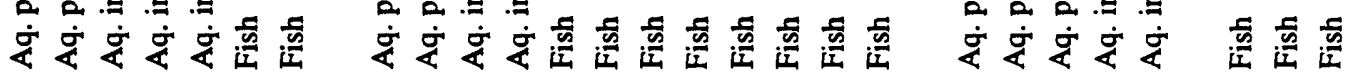

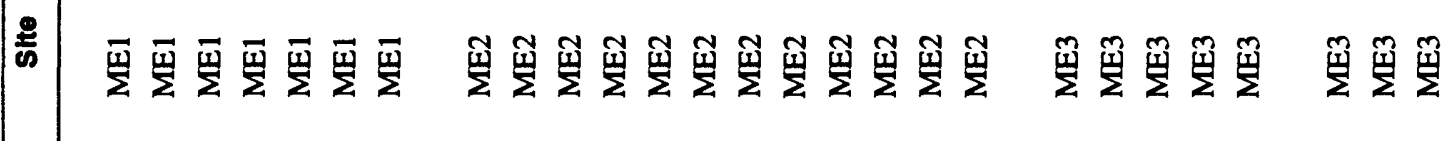




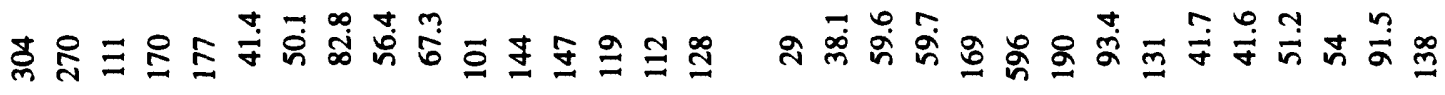

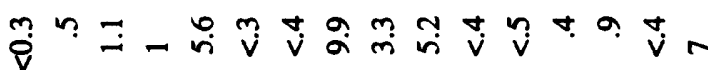

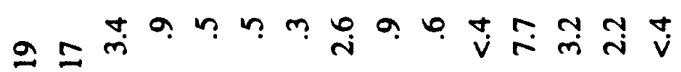

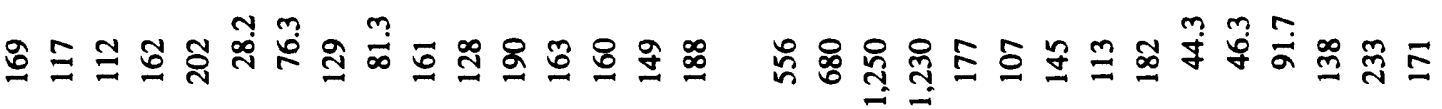

담

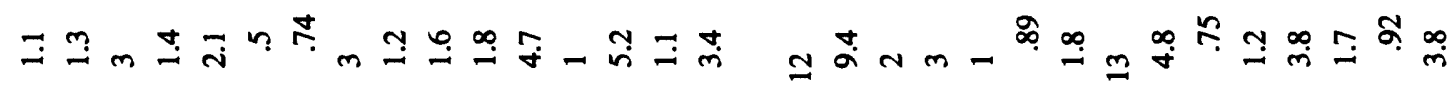

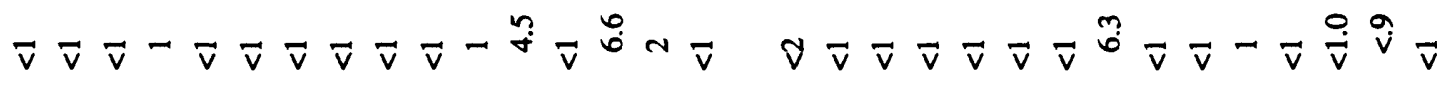

กิ

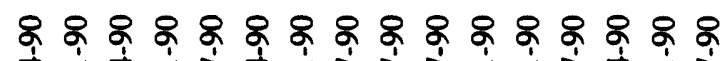

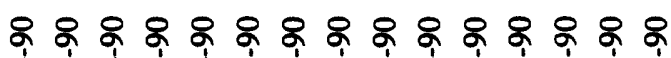

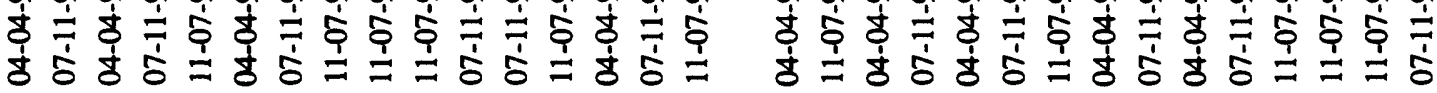

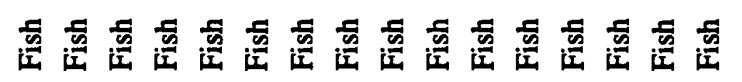

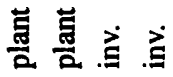

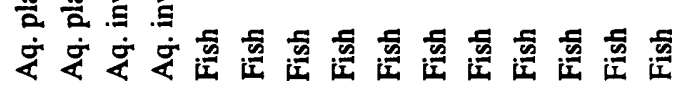




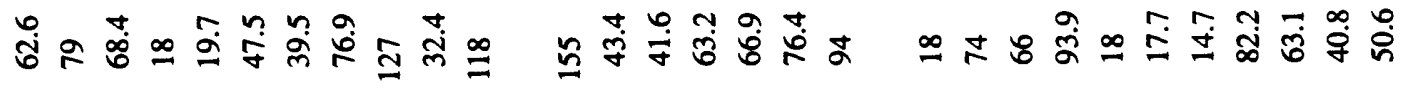

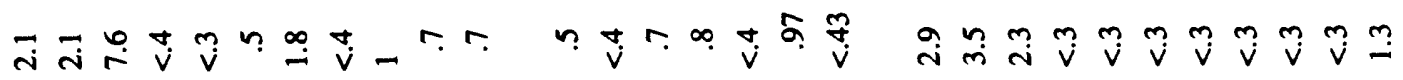

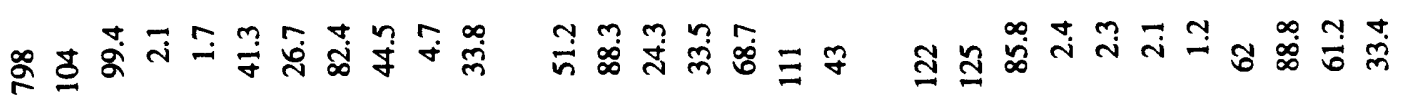

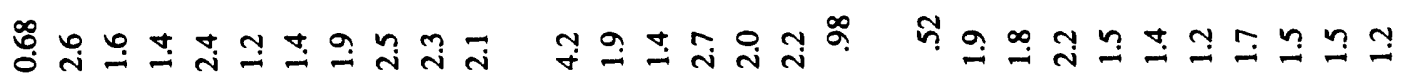

预

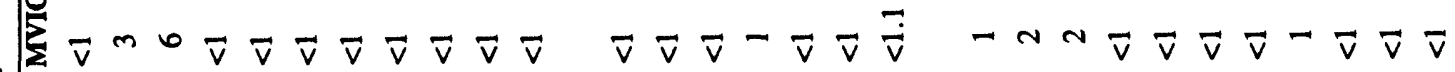

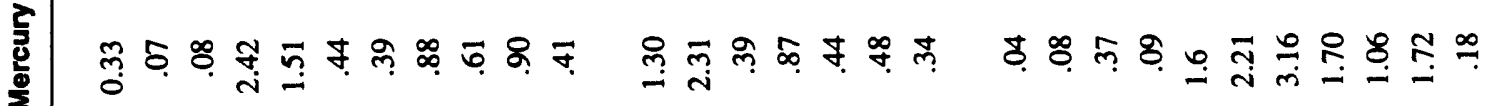

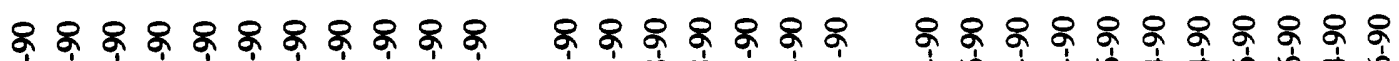

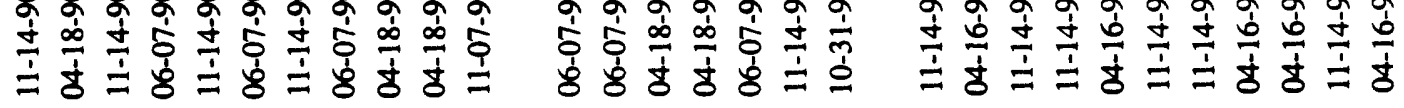

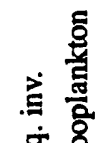

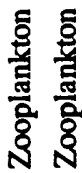

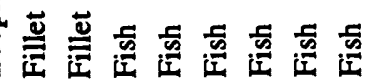

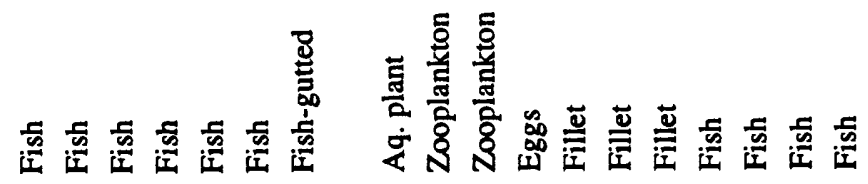

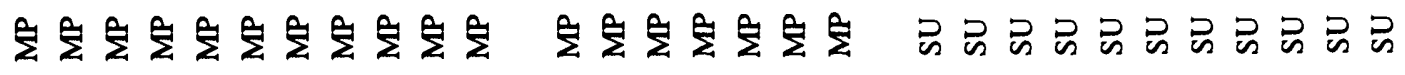



ڤิ่

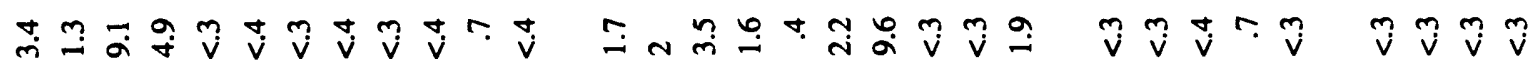

రి

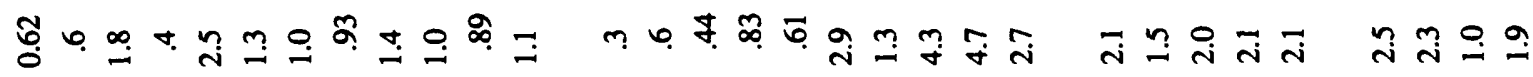

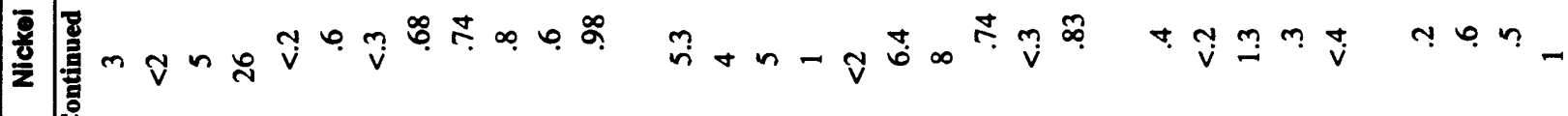

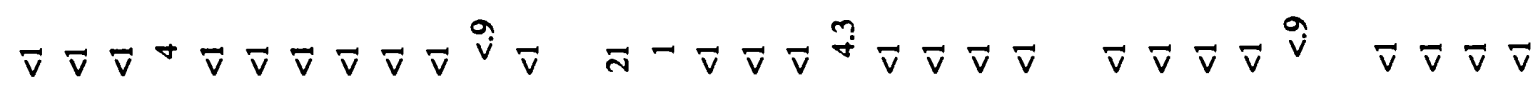

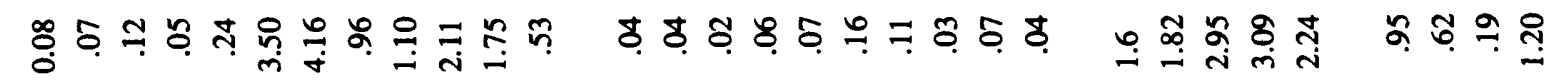

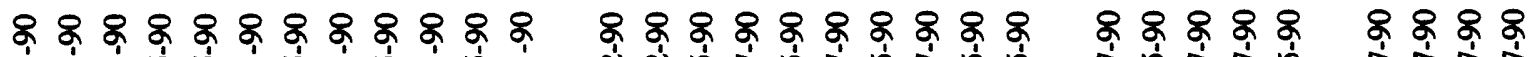
की

.े.

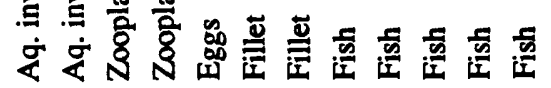

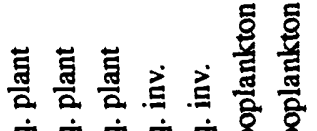

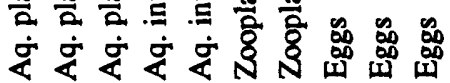

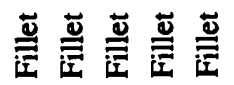

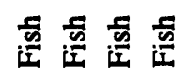

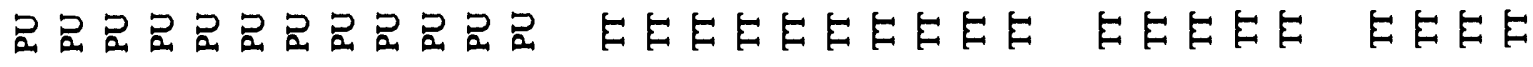




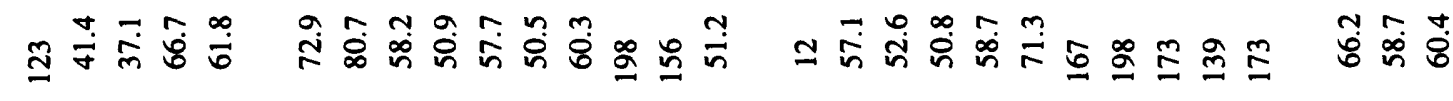

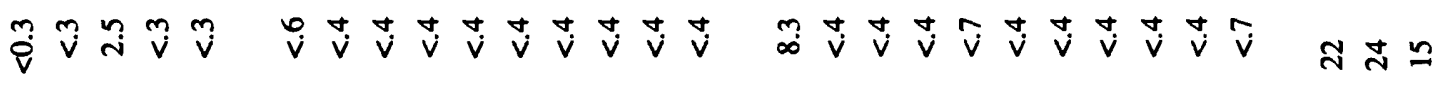

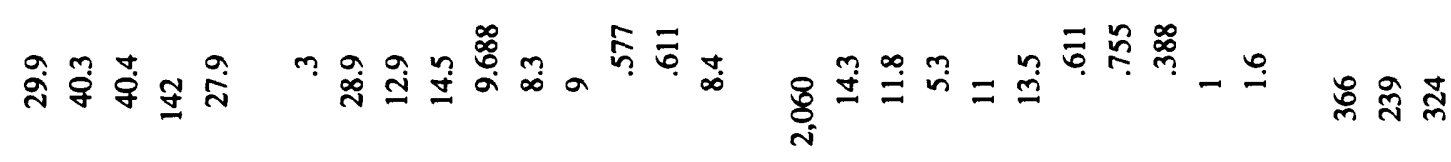

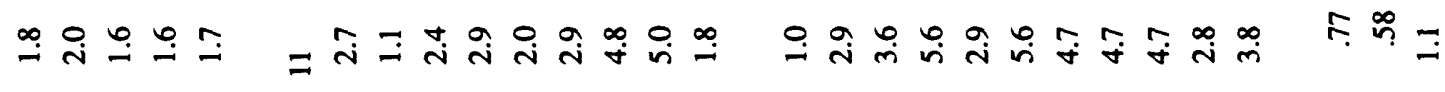
约

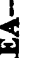

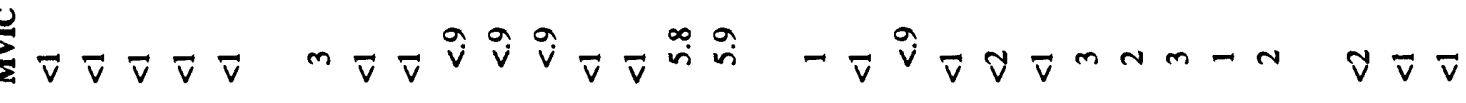

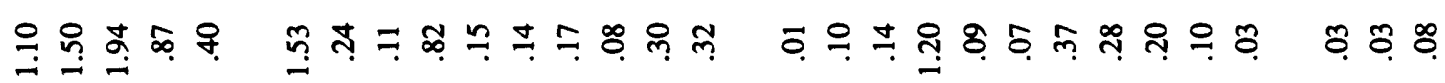

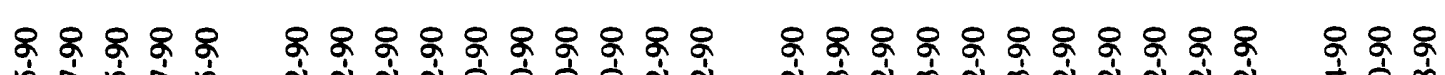

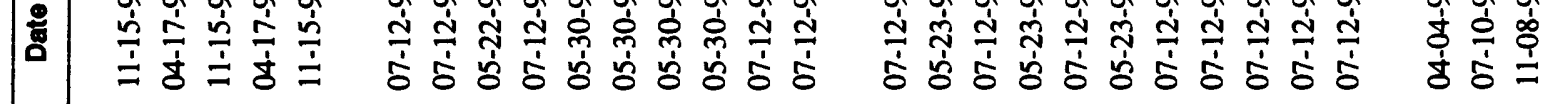

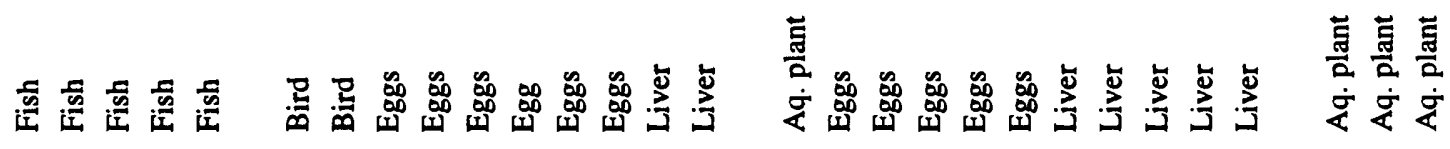

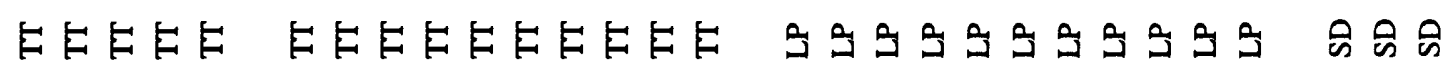


n

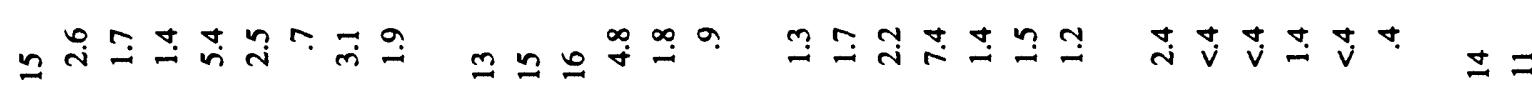

평유

茫

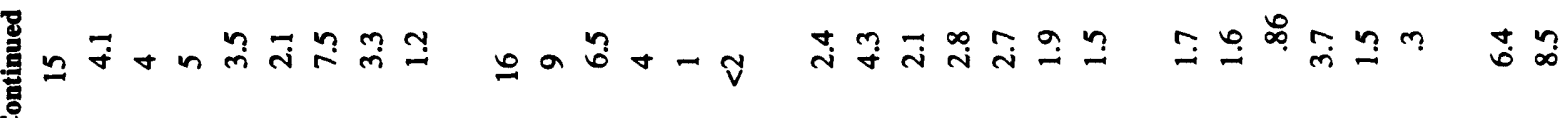

$\vec{v} \vec{v} \vec{v} \vec{v} \vec{v} \vec{v} \vec{v} \vec{v} \quad \nabla \vec{v} \vec{v}-\vec{v} \vec{v} \sim \sim-\vec{v}-\vec{v} \vec{v} \stackrel{\vartheta}{v} \vec{v} m \sim \vec{v} \quad \tilde{v} \vec{v}$

-

-

$N \sim-\vec{v}-\vec{v} \vec{v}$

ஜํㅇ

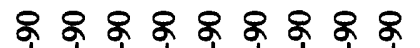

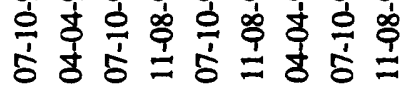

8. \& 8 \& 8 \&

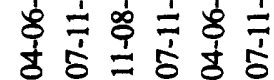

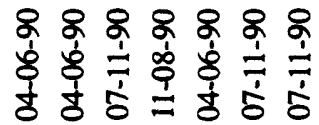

웅 웅 웅 운

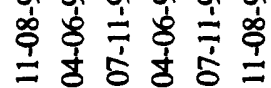

\& \&

ষे

\section{志总音}

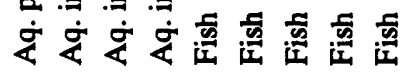

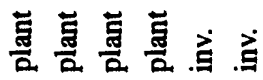
安安安安安

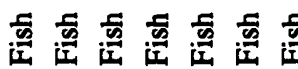

咅蒙

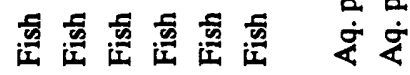

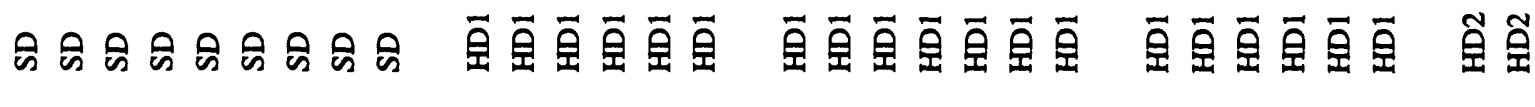




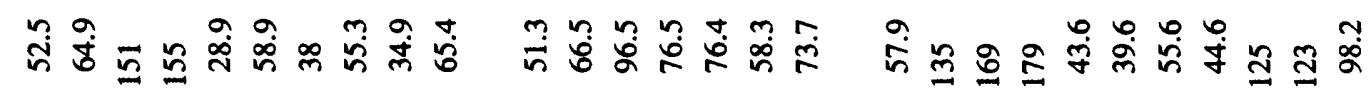

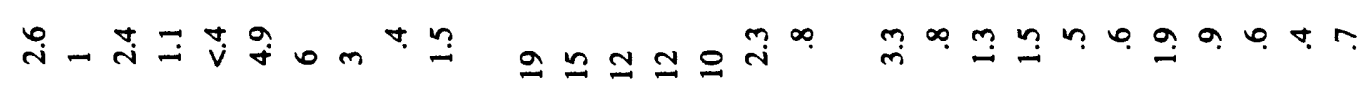

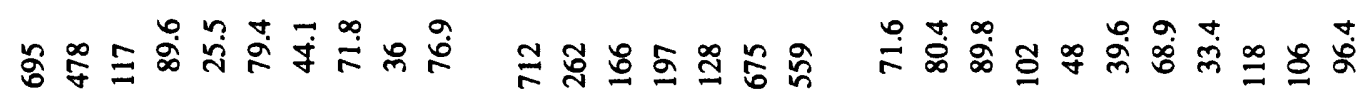

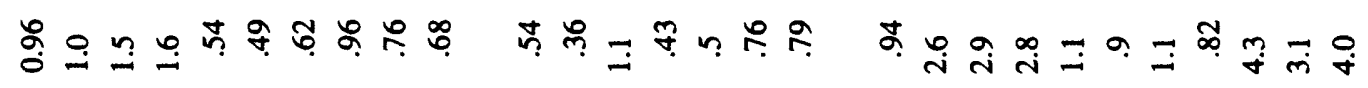

$\frac{\mathscr{\infty}}{\stackrel{0}{0}}$

m

$\stackrel{\frac{5}{5}}{2}$

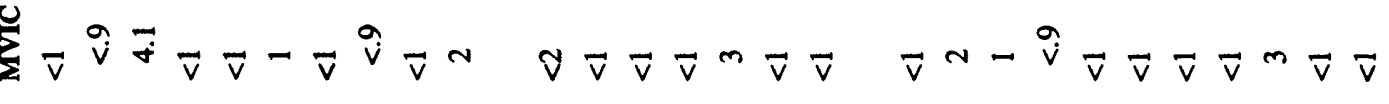

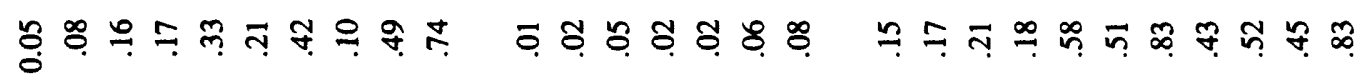

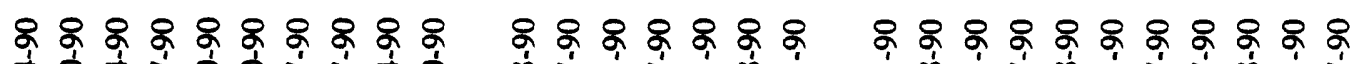

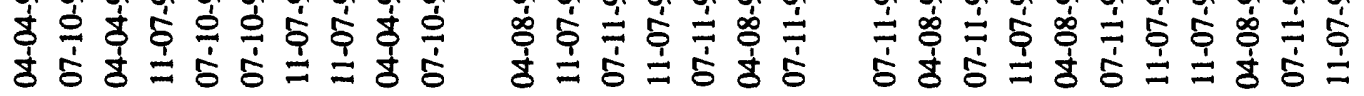

齐

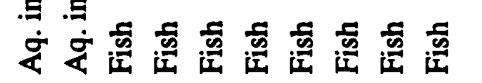

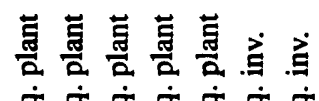

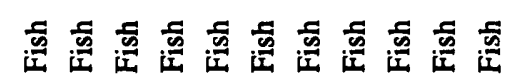

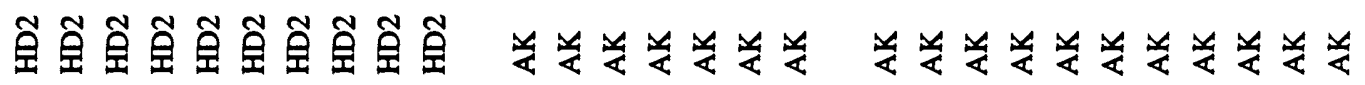




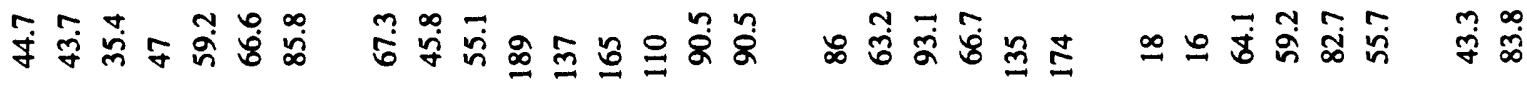

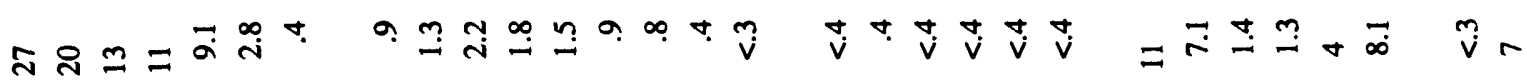

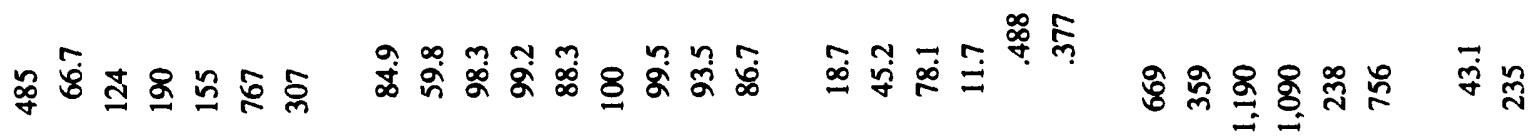

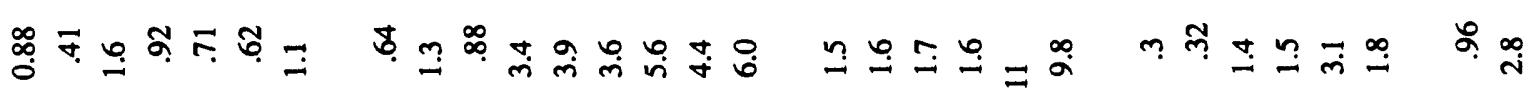

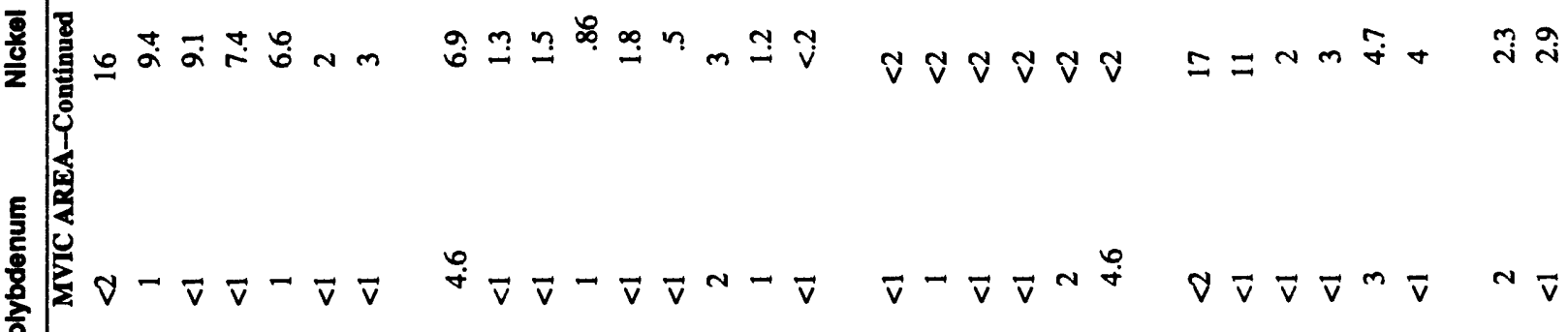

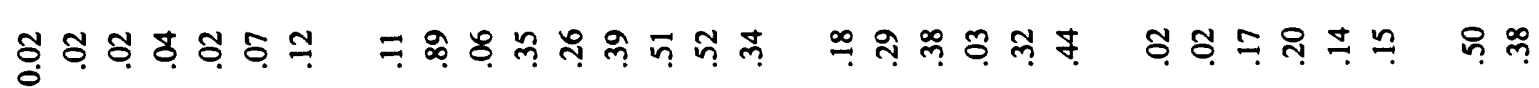

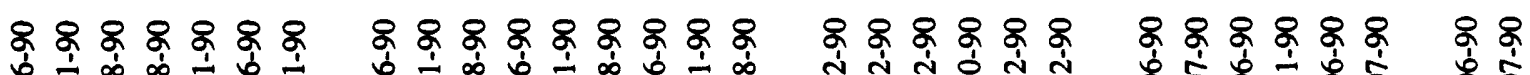

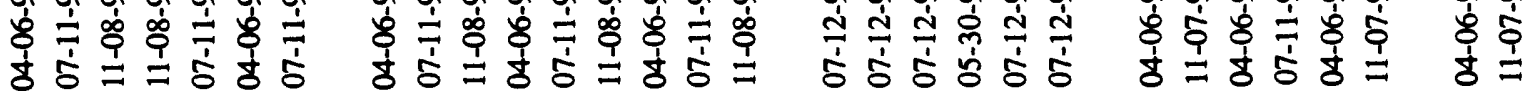

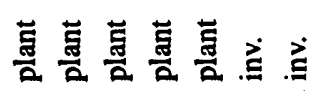
妥安安安 安 要

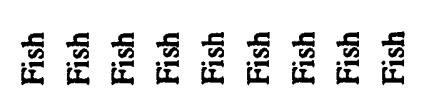

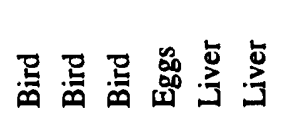

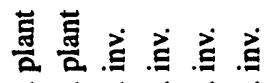

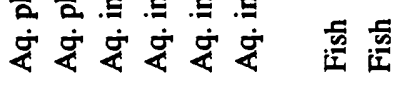

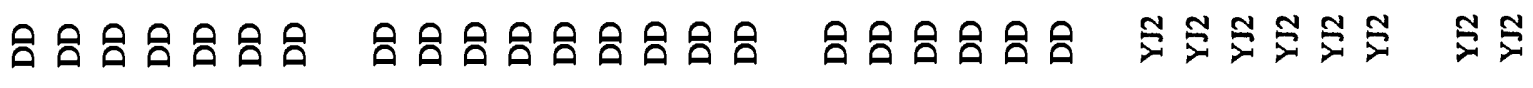




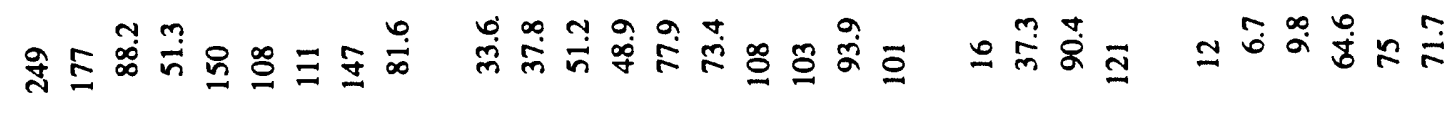

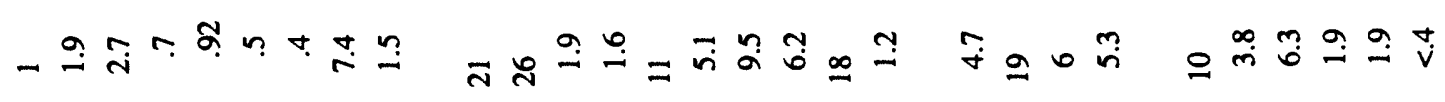

茫

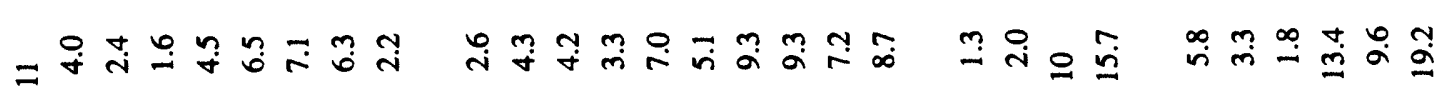

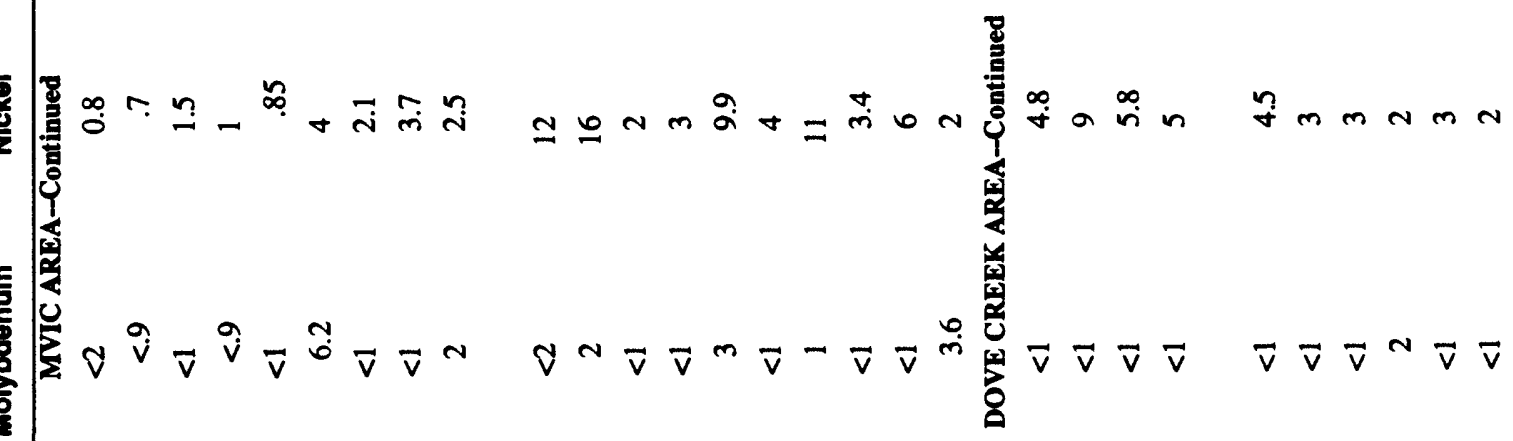

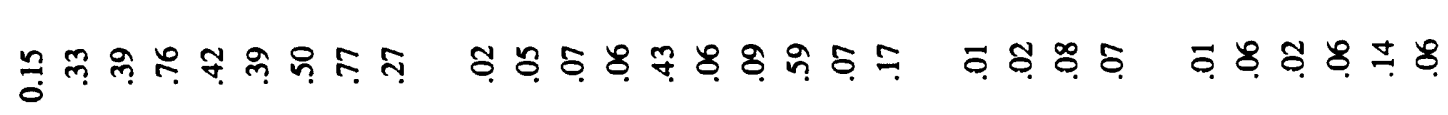

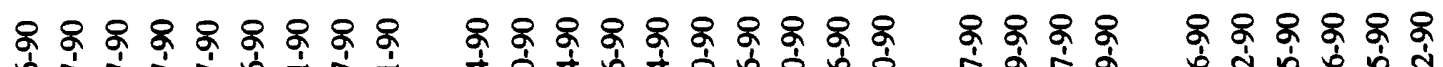

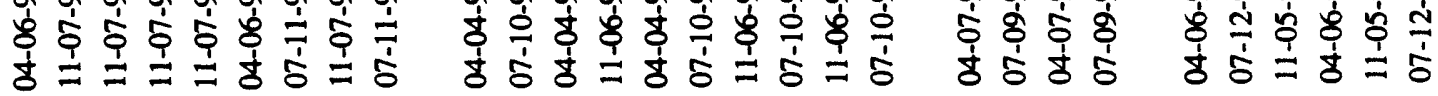

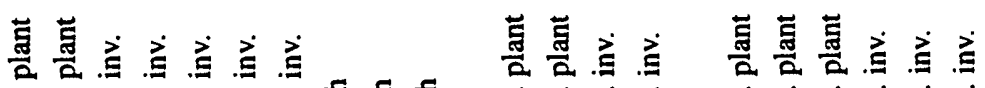

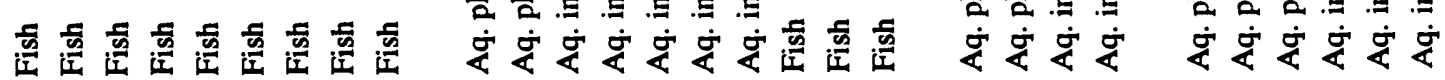

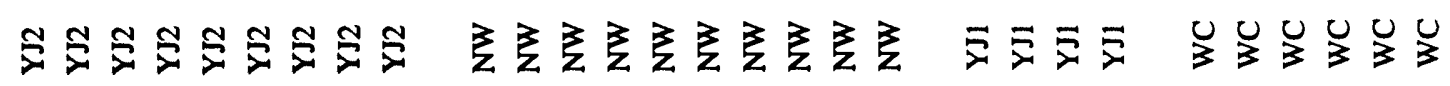


ส

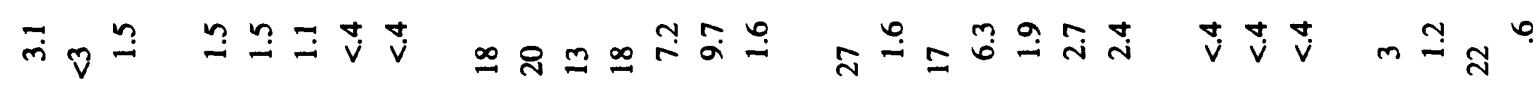

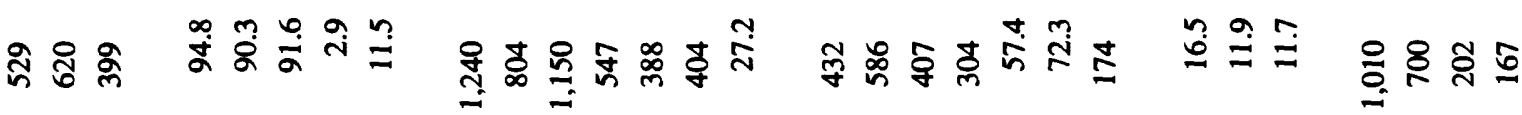

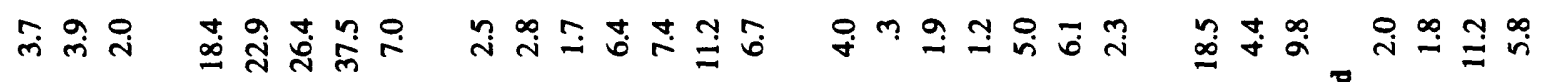

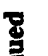

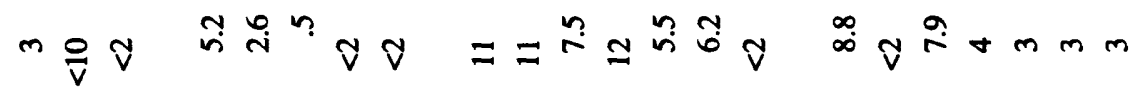

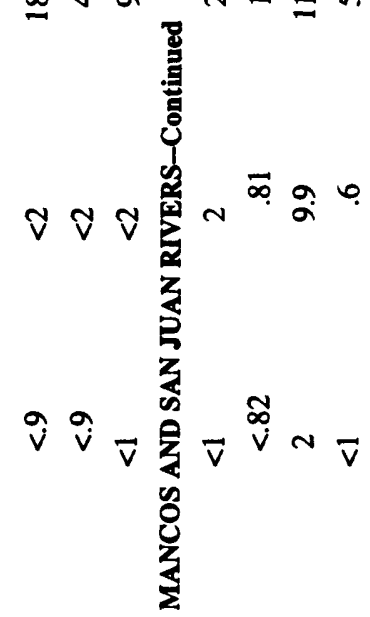

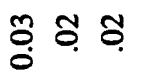

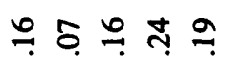

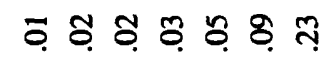

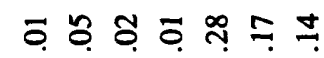

กุธ

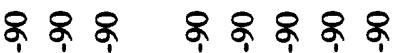

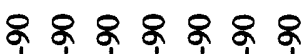

2888288

888

용ㅇㅇㅇㅛ

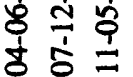

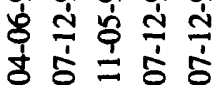

के के

ठิ่

ชे ชे के

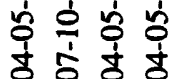

总竞总

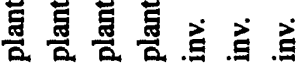

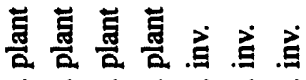

安要要

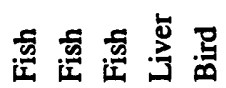

安要安安要要要

安要要要要要要

品品首㠵

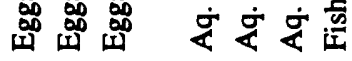

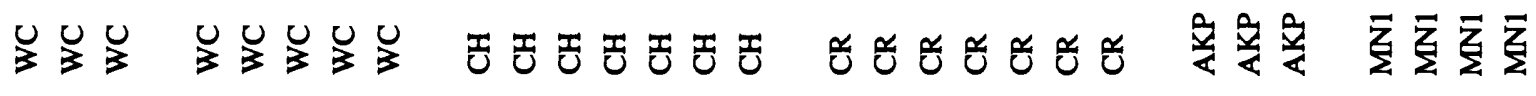




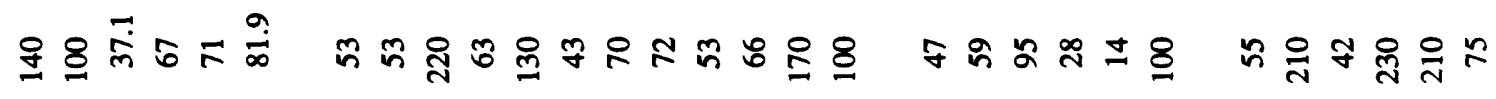

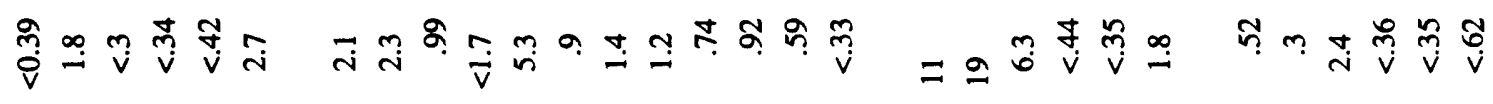

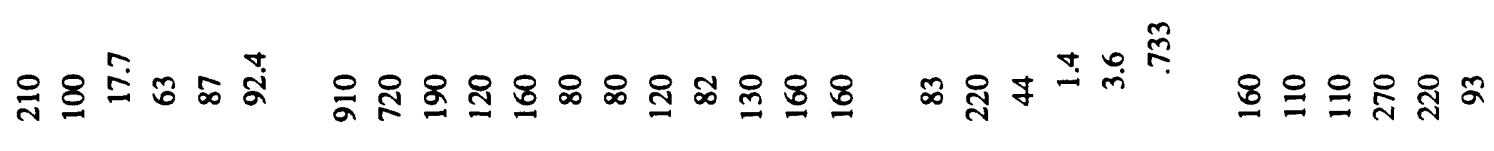

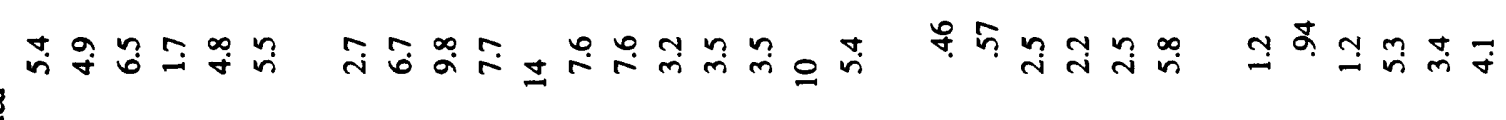

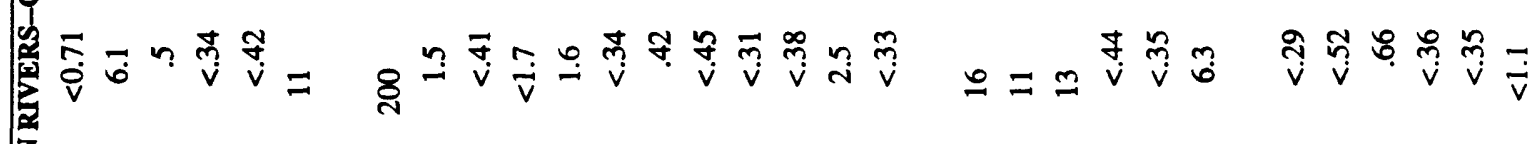
更

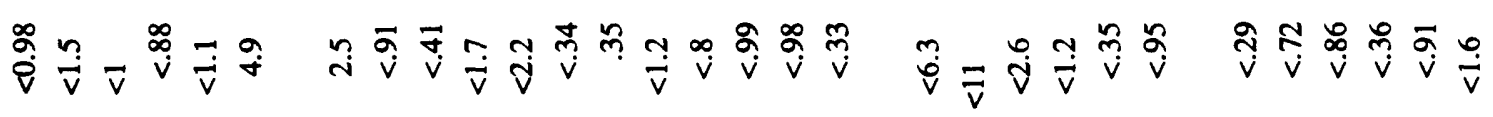

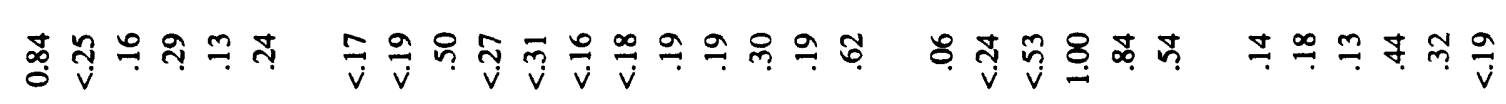

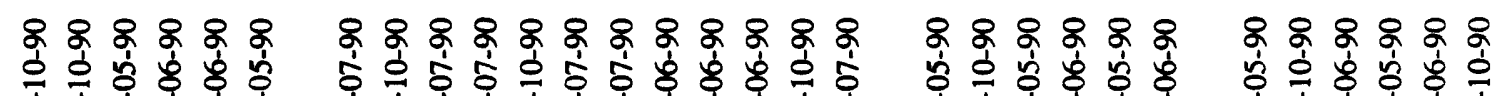

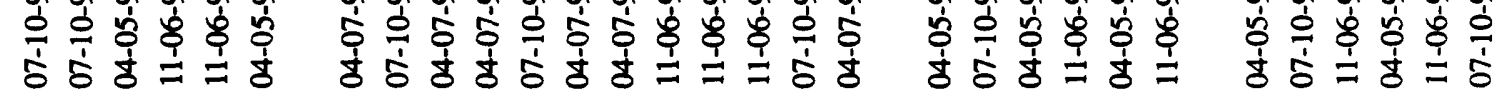

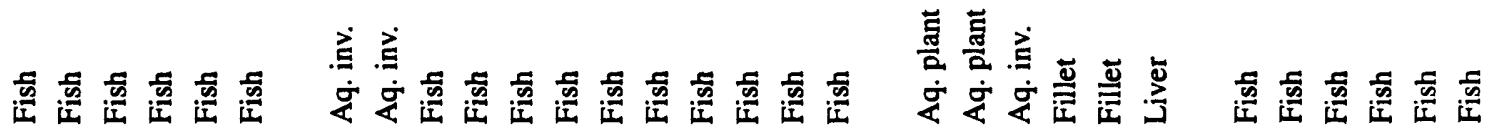

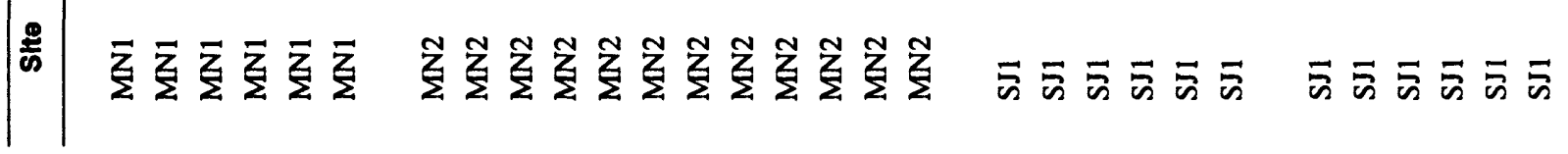


든

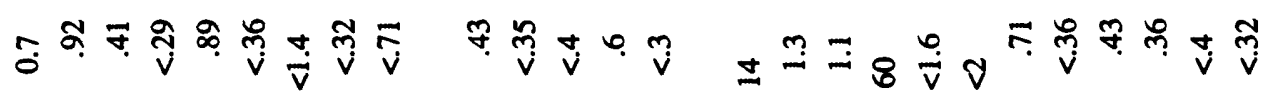

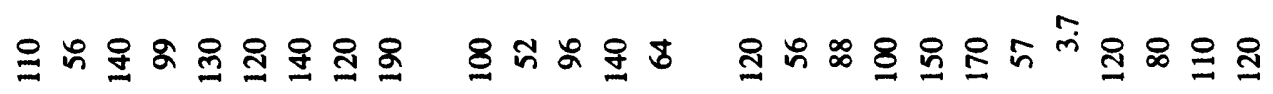

กำ

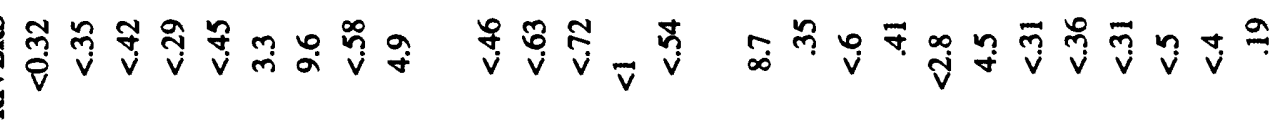

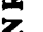

웅 ๆ

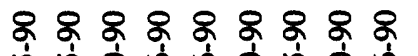

$8.8 \% 8$

$\stackrel{\nabla}{\dot{v}} \stackrel{\infty}{\infty} \vec{v} \underset{\frac{n}{v}}{\stackrel{n}{v}}$

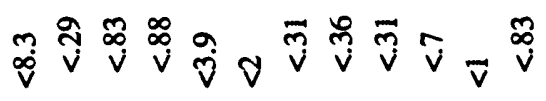

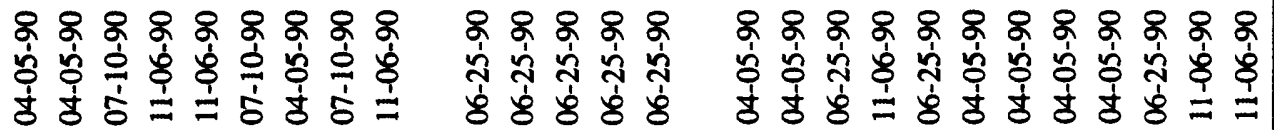

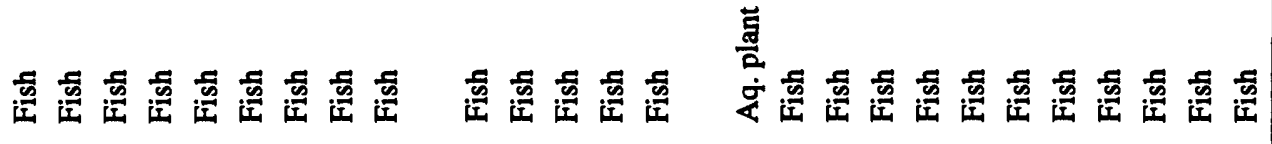

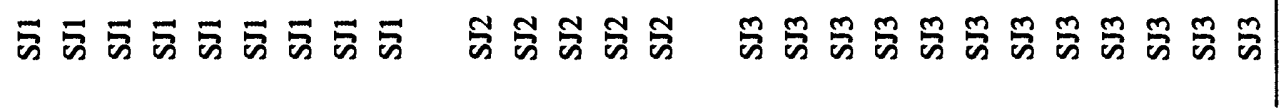




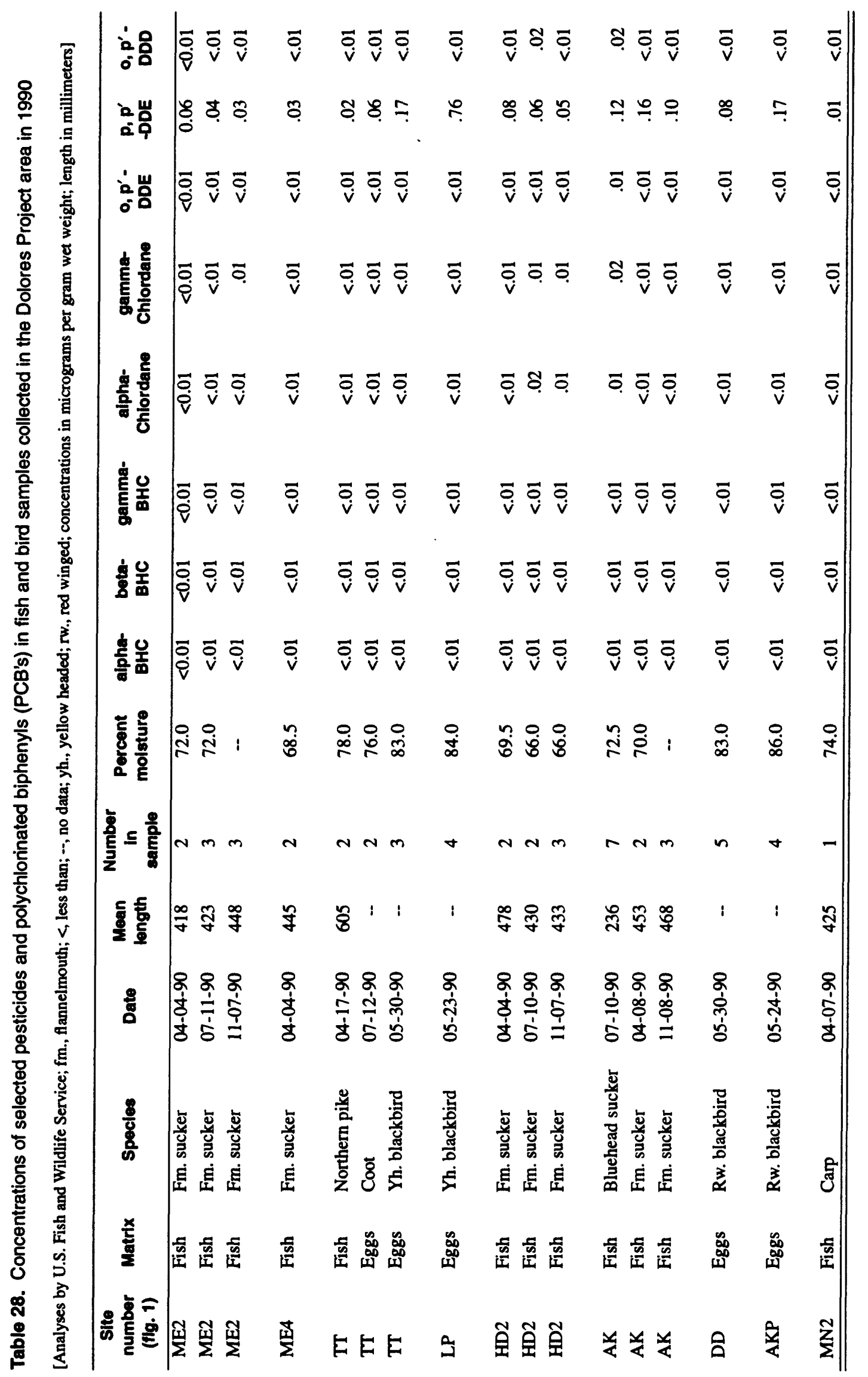




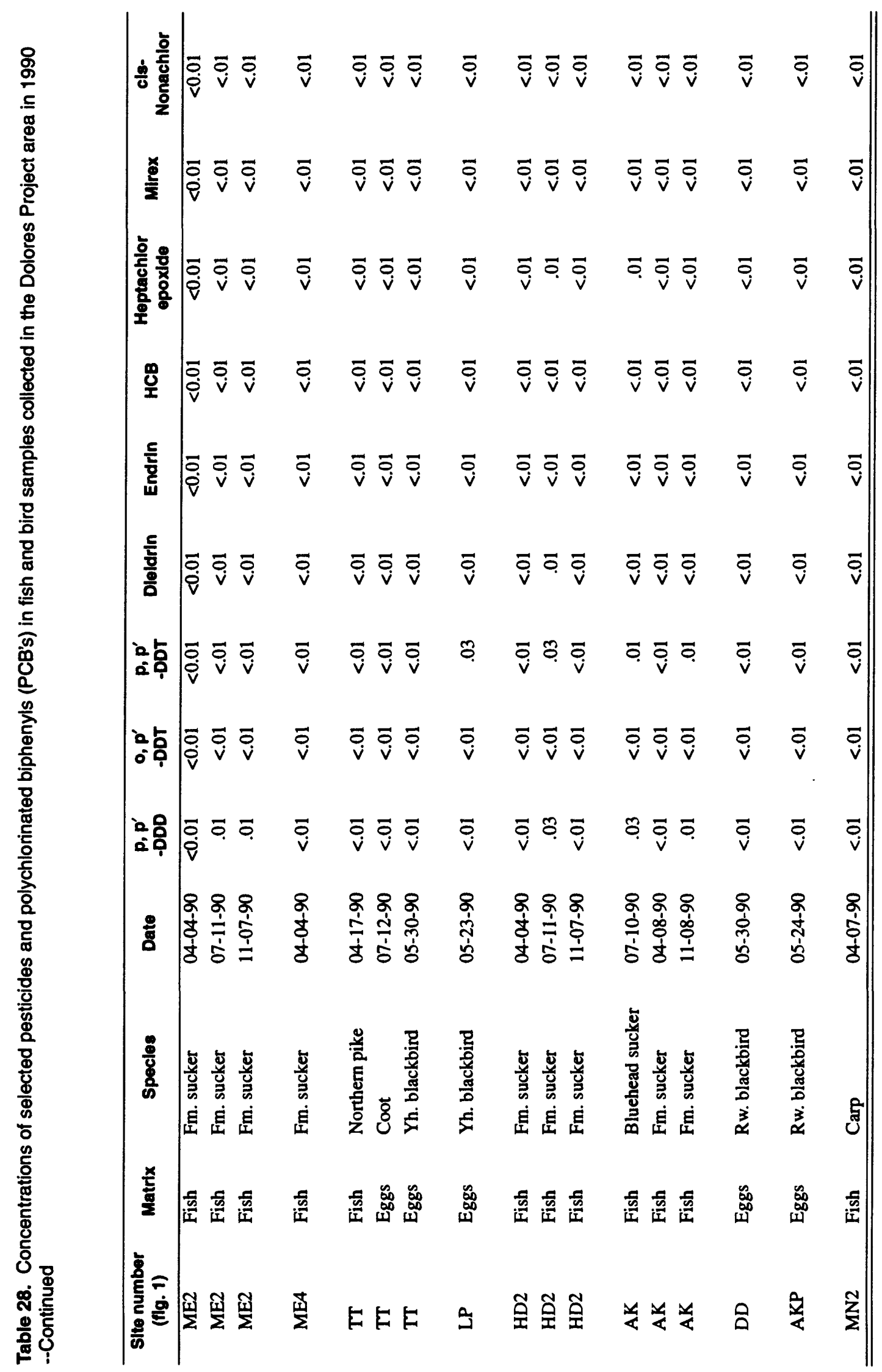




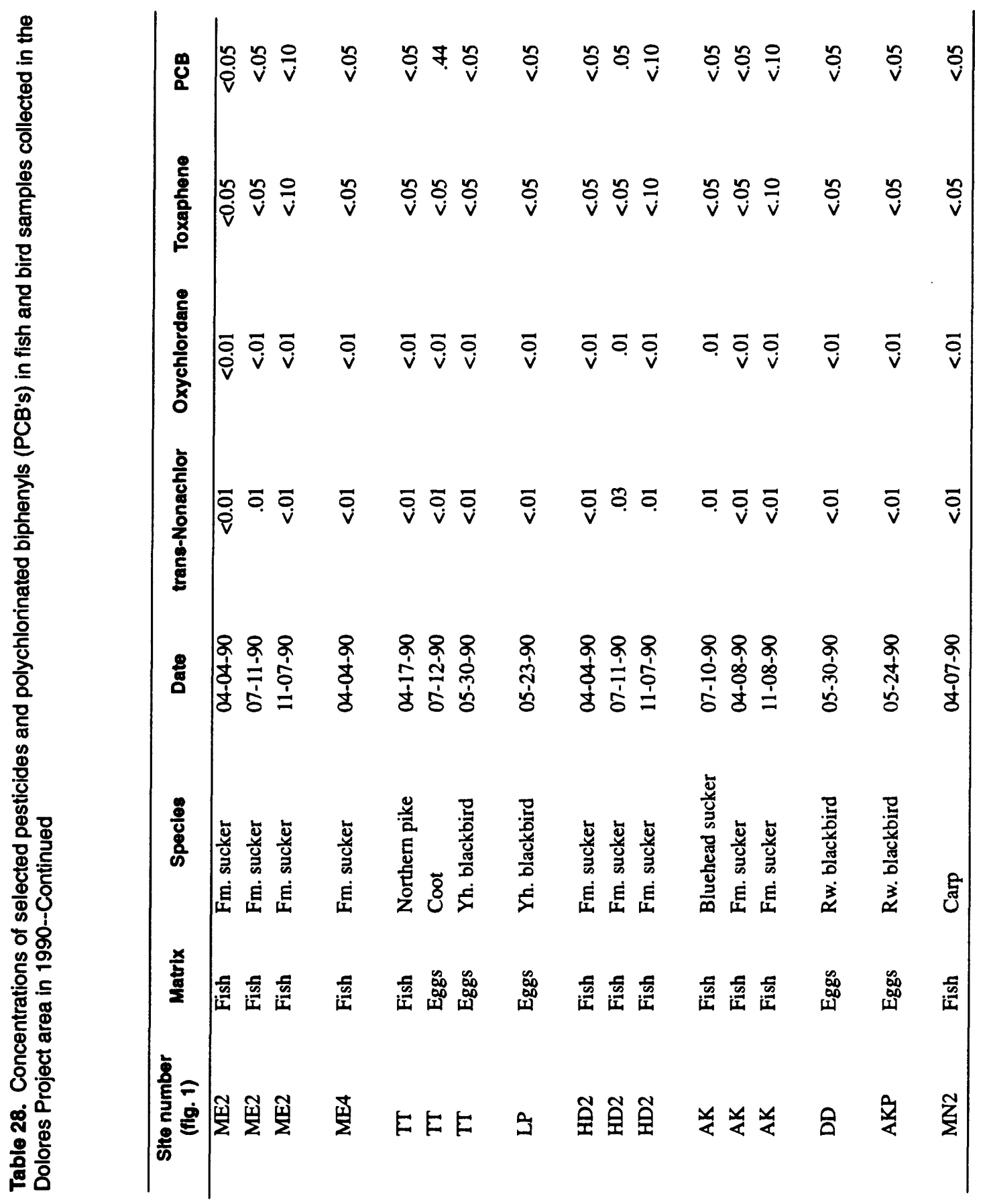


Table 29. Polycyclic-aromatic hydrocarbon (PAH) concentrations in fish bile collected in the Dolores Project area, 1990-91

[Concentrations in micrograms per gram wet weight; < less than]

\begin{tabular}{|c|c|c|c|c|c|c|}
\hline $\begin{array}{l}\text { Site number } \\
\text { (figs. 1, 2) }\end{array}$ & Specles & $\begin{array}{l}\text { Number in } \\
\text { sample }\end{array}$ & Date & Naphthalene & Phenanthrene & $\begin{array}{c}\text { Benzo [a] } \\
\text { pyrene }\end{array}$ \\
\hline ME2 & Flannelmouth sucker & 5 & $11-01-90$ & 44.0 & 10.0 & 0.18 \\
\hline ME4 & Flannelmouth sucker & 5 & $11-01-90$ & 24.0 & 4.9 & .14 \\
\hline MP & Flannelmouth sucker & 1 & $11-01-90$ & 37.0 & 19.0 & .13 \\
\hline PU & Walleye & 3 & $11-01-90$ & 46.0 & 6.8 & .24 \\
\hline TT & Northern pike & 1 & $11-01-90$ & 27.0 & 27.0 & .12 \\
\hline HD2 & Flannelmouth sucker & 7 & $11-01-90$ & 94.0 & 12.0 & .15 \\
\hline AK & Flannelmouth sucker & 5 & $11-01-90$ & 17.0 & 4.2 & $<.10$ \\
\hline AK & Flannelmouth sucker & 1 & $08-01-91$ & 77.0 & 21.0 & .18 \\
\hline AK & Flannelmouth sucker & 1 & $08-01-91$ & 84.0 & 20.0 & .33 \\
\hline AK & Flannelmouth sucker & 1 & $08-01-91$ & 66.0 & 12.0 & .16 \\
\hline AK & Flannelmouth sucker & 1 & $08-01-91$ & 67.0 & 13.0 & .18 \\
\hline AK & Flannelmouth sucker & 1 & $08-01-91$ & 65.0 & 12.0 & .20 \\
\hline MN2 & Flannelmouth sucker & 3 & $11-01-90$ & 46.0 & 8.6 & .22 \\
\hline SJ1 & Channel catfish & 1 & $11-01-90$ & 160.0 & 36.0 & .56 \\
\hline SJ1 & Flannelmouth sucker & 5 & $11-01-90$ & 59.0 & 12.0 & .21 \\
\hline SJ3 & Flannelmouth sucker & 1 & $11-01-90$ & 65.0 & 11.0 & .26 \\
\hline
\end{tabular}

126 Reconnaissance Investigation of Water Quaiity, Bottom Sediment, and Biota Associated with irrigation Drainage in the Dolores Project Area, Southwestern Coiorado and Southeastern Utah, 1990-91 